\title{
Qaraciyər REZEKSIYYASI
}

\section{Nuru Yusifoğlu BAYRAMOV}

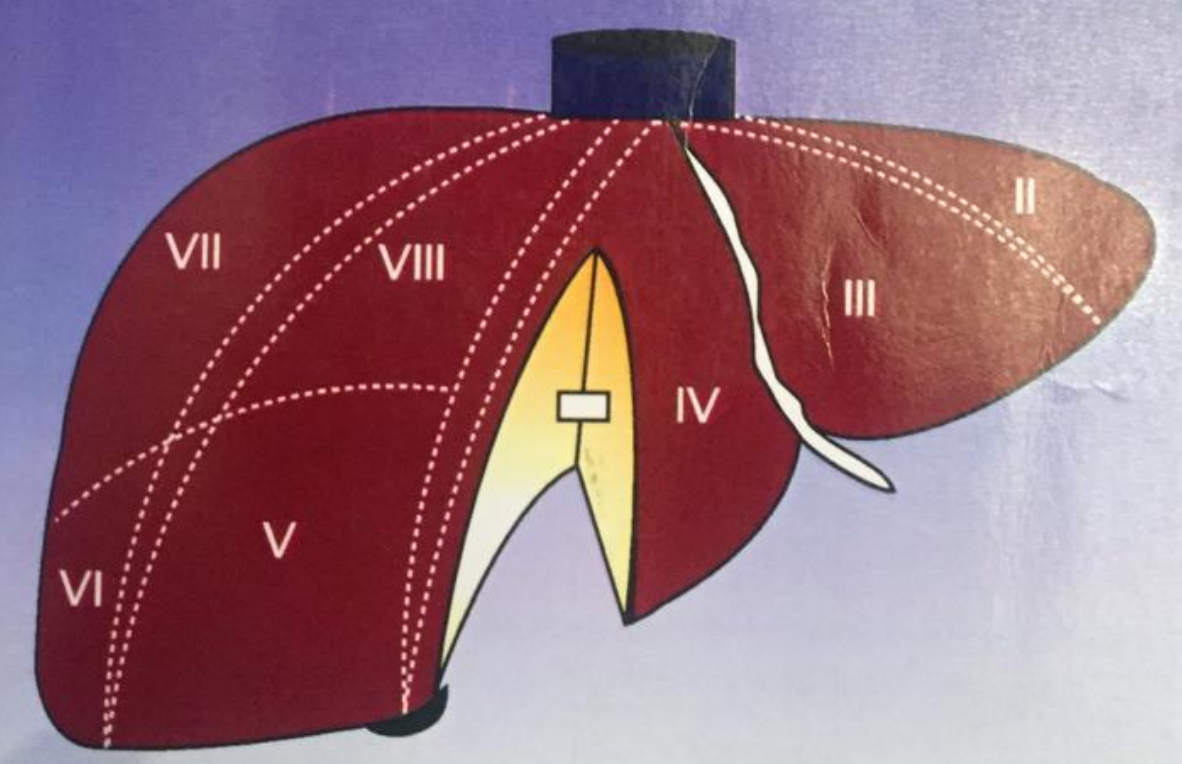

\section{ANKARA 1998}

Web site

www.bck.az

DOI https://doi.org/10.25045/k.nurubay.qcrez

ISBN 9789952536034

ORCID iD https://orcid.org/0000-0001-6958-5412 
Nuru Yusifoğlu Bayramov

\section{Qaraciyər REZEKSIYYASI}

ANKARA 1998

Web site www.bck.az

DOI 10.25045/k.nurubay.qcrez

ISBN 9789952536034

ORCID iD https://orcid.org/0000-0001-6958-5412

ANKARA 1998

ISBN: 978-9952-536-03-4 

Rə’yçilər:
Prof. Dr. S.DAMIRCi
Prof. H.A.SULTANOV
Korrektor:
Dr. T.E.BAYRAMOVA

QARACIYYR REZEKSIYYASI

Tibb elmlari namizadi, Dossent Doktor Nuru Yusifoğlu Bayramov

QARACЭYӘR REZEKSЭYASI

Tibb elmlari namizadi, Dossent Doktor Nuru Yusifoqlu Bayramov

KARACİĞER REZEKSIYYONU

Doç. Dr. Nuru Yusifoğlu Bayramov

LIVER RESECTION

PhD, Ass. Prof. Nuru Yusifoğlu Bayramov

REZEKCЭG PEQTEЭ

Kandidat medicinskix nauk, Docent Doktor Nuru Hsifoqlэ Bayramov

ISBN: 978-9952-536-03-4

(C) N.Y. Bayramov. Qaraciyər rezeksiyası. ANKARA, 1998, 273 s. ISBN- 975- 94665-3-8, ISBN: 978-9952-536-03-4

Monoqrafiya qaraciyər rezeksiyasının bir çox nəzəri və praktik məsələlərinə həsr olunmuşdur. Kitabda qaraciyərin müasir cərrahi anatomiyası, görüntüləmə və laborator müayinə üsulları, cərrahi xəstəlikləri, rezeksiya üsulları, əməliyyatdan sonrakı ağırlaşmalar haqqında müasir dünya ədəbiyyatındakı mə'lümatlar müzakirə edilmiş və ümumiləşdirilmiş şəkildə təqdim edilmişdir. Qaraciyər rezeksiyasının, qaraciyər travmalarının orijinal təsnifatından bəhs edilmişdir. Qaraciyərin rezektabelliyini tə’yin etmək üçün yeni əməliyyatdaxili müayinə üsulunun tətbiqi haqqında mə'lumat verilmişdir. Normal və fibrotik qaraciyərdə parenximanı kəsmək üçün istifadə olunan əzmə, ultrasəs bıçağı və ultrasəs bıçağı ilə arqonlu koaqulyatorun birgə tətbiqi üsulları ilə əlaqədar aparılan oriijinal klinik tədqiqatın nəticələri təqdim edilmişdir.

Monoqrafiya cərrahlar, elmi işçilər üçün nəzərdə tutulmuşdur. 273 səh., 53 şəkil və qrafik, 15 cədvəl, 464 ədəbiyyat

* Türkiya Cumhuriyyati Madaniyyat Nazirliyi tarafindan 31.07.1998 tarihi va ISBN- 975- 94665-3-8 sayl ila naşrina icaza verilmişdir. Elektron naşr üçün ISBN: 978-9952-536-03-4 


\section{METADATA}

Type Book

Title Qaraciyər rezeksiyası

\section{Editor}

\section{Edition}

Authors Bayramov Nuru Yisufoğlu

Experts Demirçı S, Sultanov H.A.

Year $\quad 31.07 .1998$

Pages $\quad 273$

Abstract Monoqrafiya qaraciyər rezeksiyasının bir çox nəzəri və praktik məsələlərinə həsr olunmuşdur. Kitabda qaraciyərin müasir cərrahi anatomiyası, görüntüləmə və laborator müayinə üsulları, cərrahi xəstəlikləri, rezeksiya üsulları, əməliyyatdan sonrakı ağırlaşmalar haqqında müasir dünya ədəbiyyatındakı mə'lümatlar müzakirə edilmiş və ümumiləşdirilmiş şəkildə təqdim edilmişdir. Qaraciyər rezeksiyasının, qaraciyər travmalarının orijinal təsnifatından bəhs edilmişdir. Qaraciyərin rezektabelliyini tə'yin etmək üçün yeni əməliyyatdaxili müayinə üsulunun tətbiqi haqqında mə'lumat verilmişdir. Normal və fibrotik qaraciyərdə parenximanı kəsmək üçün istifadə olunan əzmə, ultrasəs bıçağı və ultrasəs bıçağı ilə arqonlu koaqulyatorun birgə tətbiqi üsulları ilə əlaqədar aparılan oriijinal klinik tədqiqatın nəticələri təqdim edilmişdir. Monoqrafiya cərrahlar, elmi iş̧̧ilər üçün nəzərdə tutulmuşdur. 273 səh., 53 şəkil və qrafik, 15 cədvəl, 464 ədəbiyyat

Keywords Qaraciyər, rezeksiya, anatomya, seqment, seqmentar anatomiya, USM, KT, MRT, kist, törəmə, hepatik adenoma, hemangioma, fokal nodulyar hiperplaziya, hepatosellular karsinoma, 
xolangiokarsinoma, CUSA, arqon, koaqulyasiya, əzmə, təsnifat, liver, resection, karaciger, rezeksiyon

\begin{tabular}{|c|c|}
\hline City & Ankara \\
\hline Publisher & Print-72 matba, elektron-Azərbaycan Tibb Universiteti \\
\hline Language & Azerbaijani \\
\hline $\begin{array}{l}\text { Type of } \\
\text { work }\end{array}$ & Monography \\
\hline URL & www.bck.az \\
\hline DOI & 10.25045/k.nurubay.qcrez \\
\hline ISBN & 9789952536034 \\
\hline RCID iD & https://orcid.org/0000-0001-6958-5412 \\
\hline
\end{tabular}




\section{ÖN SÖZ}

Ovvallar qaraciyarin müayina üsullarının va rezeksiya texnikasinın yetərsizliyi ila alaqadar qaraciyər rezeksiyası imkanları zaif idi. Lakin, son illar görüntülamə üsullarının geniş tətbiqi sayəsində qaraciyər töramələrinin erkən, rezektabel dövrda aşkar edilmə imkanları artmışdır. Intraarterial, intraportal kimyaterapevtik embolizasiya üsullarl qeyri-rezektabel şişləri rezektabel vaziyyata gatira bilir. Canlılardan qaraciyər parçasının köçürülməsi üsulu geniş tətbiq edilməyə başlamışdır. Bununla yanaşı ultrasəs bıçağının geniş istifadəsi nəticasində qaraciyər rezeksiyalarında ağırlaşmalar ciddi şəkildə azalmışdır. Lakin, rezeksiyanın bir çox problemləri, xüsusən sirrotik qaraciyərdə aparılan rezeksiyalarda qanaxma, əməliyyatdan sonrakı ă̆ırlaşmalar, qaraciyərin rezektabelliyi problemlori hazırda tam hallini tapmamışdır.

Taqdim edilan monoqrafiya aslinda bu problemlarin hallina yönalmiş bir tadqiqat asaridir. Ultrasəs bıçă̆l ila arqonlu koaqulyatorun birgə tətbiqi üsulu sirrotik qaraciyər rezeksiyalarında qanaxma problemini hall etməyə ümid verməkdədir. Oməliyyatdaxili indosianin yaşıl sinağ rezektabelliyini to'yin etmək, aməliyyatdan sonrakı qaraciyər yetməzliyini proqnozlaşdırmaq üçün obyektiv bir üsuldur va geniş tatbiqi tövsiya olunur.

Bunlardan başqa, qaraciyərin corrahi anatomiyası, qaraciyər xəstวlikləri vo ağırlaşmalarının müalicasi ila alaqadar verilon orijinal sxemalar va alqoritmlar praktik faaliyyat üçün faydalı va yararlıdır. Kitabda bahs edilon qaraciyarin travmalart va rezeksiyaların tasnifatarı da orijinaldır.

Natica olaraq, taqdim edilon monoqrafiya qaraciyar rezeksiyasının bir çox nəzəri va praktiki cəhətlarini müasir mə’lumatlar işı̆̆ında comlaşdirən, orijinal tədqiqatlar va yeniliklardan bəhs edən, son bir neçə ildə hepatologiyanın ehtiyac duyduğu elmi-praktik asərdir. Kitabın oxuyucular tərəfindən do bayanilacayina ümid ediram.

Prof. Dr. S.DAMIRCI 


\section{$\ddot{O} N$ SöZ}

\section{Monoqrafiya bir çox nöqteyi-nozordon əhomiyyotli vo faydalı elmi-praktik osordir.}

Birincisi, qaraciyərin corrahi anatomiyast, xəstaliklari, müayinə üsullarl, rezeksiya üsulları vo əməliyyatdan sonrakı ağırlaşmalar haqqında müasir elmi-praktik mə'lumatları əhatə edən, ölkəmizdə və son illar dünya adabiyyatında çıxan ilk asardir.

İkincisi, qaraciyərin corrahi xəstəliklarinin, aməliyyatdan sonrakı ă̆ırlaşmaların müalicə alqoritmlari, rezeksiya texnikasının ardicll va hartarafli tasviri bunların praktik faaliyyato tatbiqini xeyli asanlaşdırır.

Üçüncüsü, kitabda bir çox tadqiqat işinin naticalari va elmi-praktik yeniliklar verilmişdir. Qaraciyar travmalarının va rezeksiyasının orijinal tasnifatından bahs edilmişdir. Taklif edilan yeni obyektif amaliyyatdaxili indosianin yaşıl sınağı sirrotik qaraciyər rezeksiyalarında qaraciyarin rezektabelliyini to'yin etmək va aməliyyatdan sonrakı qaraciyər yetmazliyinin proqnozlaşdırılması üçün alverişli üsuldur. Qaraciyər rezeksiyasında qanaxmanı azaltmaq üçün təklif edilən ultrasəs bıçağl ilə arqonlu koaqulyatorun birga tatbiq üsulu haqqında geniş mə'lumat verilmişdir.

Bir sözla, monoqrafiya carrahlarımız va elmi işçilarimiz üçün faydalı olan elmi tadqiqat asəri va praktik rəhbərdir. Kitabın oxuyucular tərəfindən do yüksək qiymətləndirilacəyinə ümid edirəm.

Tibb elmləri doktoru, Professor H.A.SULTANOV 


\section{Müəllifdən}

Kitabda bəhs edilən klinik təcrübəmizin əsasında Türkiyə Yüksək İhtisas Xəstəxanasının Qastroenteroloji Cərrahiyyə şöbəsində, Ankara Universiteti Cərrahi Onkoloji Bölümündə, Başkent Universiteti Orqan Nakli Xəstəxanasında və Yüzüncü Y1l Universiteti Ümumi Cərrahiyyə Klinikasında müalicə olunan xəstələrdə aparılan qaraciyər rezeksiyaları durur.

Türkiyədə elmi tədqiqat işləri aparmamızda və bu kitabın ortaya çıxmasında maddi, mə’nəvi və elmi köməklərini əsirgəməyən Azərbaycan Səhiyyə Nazirliyinə, Nazir Prof. Ә.Insanova və Kadrlar Şöbəsinin Rəisi S.Kərimova, N.Nərimanov adına Azərbaycan Tibb Universitetinə və Rektoru Prof. Ә. Omiraslanova, I Cərrahi Xəstəliklər kafedrasına və müdürü Prof. H.Sultanova, Xəzər Gəmiçiliyi Şirkətinə və T.Aşurova, Türkiyə Sağlık Bakanlığına, Türkiyə Yüksək İhtisas Xəstəxanası Cərrahi Qastroenteroloji Bölümünə və Başkanı Doç.Dr.M.Akoğluna, Başkent Universitetinə və Rektoru Prof.Dr. M.Haberala, Ankara Universiteti Cərrahi Onkoloji Bölümünə və Prof.Dr.S.Damirciya, Kırıkkale Universiteti Rektoru Prof.Dr.T.N.Durluya, Kırıkkale Universiteti Tıbb Fakültəsi Dekanı Prof. Dr.O.Karabağa, M.Aşurova, Dr.T.E.Bayramovaya, həmkarlarıma, dostlarıma, arkadaşlarıma, ailəmə dərin hörmətlərimi, sayğılarımı, təşəkkürlərimi bildirirəm.

Kitabda bəhs edilən mövzularla, kitabın quruluşu ilə, kitabda nəzərdən qaçırdı̆̆ımız orfoqrafik, qramatik və texniki səhvlərlə əlaqədar oxuyucularımızın tənqidi qeydlərini hörmət və ehtiramla qarşılayacaq və bunlar müəllifi sevindirəcəkdir.

Müəllif 


\section{MÜNDӘRİCAT}

Ön söz

Ön söz

Müəllifdən

I Bölüm. Qaraciyərin corrahi anatomiyası 3

Orqanotopiyası 3

Qaraciyər bağları 4

Qaraciyər damarları və öd axacaqları 6

Qaraciyərin daxili arxitektonikası və seqmentar anatomiyası 13

Bölümün ədəbiyyat1 29

II Bölüm. Qaraciyərin müayinə üsulları 30

GÖRÜNTÜLӘMə ÜSULLARI 31

Ultrasəs müayinəsi 31

Doppler usm 35

Bilgisayarlı tomoqrafiya 36

Nüvə-maqnit rezonans tomoqrafiya 39

Qaraciyər xəstəliklərinin görüntüləmə əlamətləri və 40 sindromları

LABORATOR MÜAYINOLəR 47

Hepatositlərin zədələnmə göstəriciləri 47

Sintetik funksiyalar $\quad 49$

Qaraciyərin zərərsizləşdirmə funksiyaları $\quad 52$

Qaraciyərin energetik-metabolik funksiyası 56

Sekretor funksiya göstəriciləri 58

Şiş və virus markerləri $\quad 60$

Qaraciyər xəstəliklərinin laborator sindromları 62

Bölümün ədəbiyyatı 65

III Bölüm. Qaraciyər rezeksiyasına göstorişlər vo əks 71

göstorişlar

QARACIYYRIN KISTLORİ 73

Anadangalma kistlor $\quad 73$

$\begin{array}{ll}\text { Neoplastik kistlor } & 78\end{array}$

$\begin{array}{ll}\text { Travmatik kistlər } & 79\end{array}$

Parazitar kistlər $\quad 79$

Qaraciyər absesi 85

Qaraciyər kistlorinin differensial diaqnostikası və 87

rezeksiyaya göstərişlər

QARACIYORIN BODXASSəLI ŞIŞLӘRI 92

Hepatosellular xərçəəng $\quad 92$

Xolangiokarsinoma 98

Metastatik qaraciyər şişləri 100

QARACIYORİN XOŞ XASSOLI Şİ̧̧LORİ 110

Heptosellular adenoma 110 
Fokal nodulyar hiperplaziya 111

Hemangioma 114

QARACIYวRIN DÍĞOR ŞIŞLəRİ 118

QARACIYכRIN TOXUMALI TÖRכMəLəRININ DIFFERENSIAL 119

DIAQNOSTIKASI

QARACIYOR TRAVMALARI 122

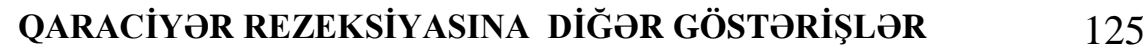

QARACIYORIN REZEKTABELLIYI

Bölümün yekunu 132

Bölümün ədəbiyyatı 136

IV Bölüm. QARACIYORIN REZEKSIYA ÜSULLARI 143

Qaraciyər rezeksiyasının təsnifatı 143

Qanaxmanı dayandırma üsulları $\quad 148$

Parenximanı kəsmə üsulları 151

Bölümün ədəbiyyatı 164

V Bölü̈. QARACIYOR REZEKSIYASININ TEXNIKASI 181

Oməliyyatönü hazırlıq 181

Qaraciyər rezeksiyası əməliyyatının gedişi 182

Bölümün yekunu 205

VI Bölü̈. QARACIYӘR REZEKSIYASINDA ӘZMӘ, 209

ULTRASOS BIÇAĐI VO ARQONLU KOAQULYATORUN

TOTBIQI

Normal qaraciyərlərdə rezeksiya üsullarının qarşılıqlı 214 müqayisəsi

Fibrotik qaracıyərlərdə rezeksıya üsullarının qarşılıqlı 222 müqayisəsi

Bölümün yekunu 232

VII Bölüm. QARACIYOR REZEKSIYALARINDAN SONRAKI 233

AĐIRLA MALAR

Qanaxmalar $\quad 235$

Hava emboliyast 243

Hidrotoraks 243

Assit 246

Öd fistulları 249

Davamli sariliq 252

Mexaniki sariliq $\quad 252$

Qarındaxili absess 254

Intrabdominal qanaxma 257

Mo'do-bağırsaq qanaxmaları 257

Qaraciyar yetmozliyi 266

Bölüimün adobiyyatı 270

MÜNDӘRICAT 276 


\section{Bölüm}

\section{QARACIYORIN CORRAHI ANATOMIYASI}

Qaraciyər insan bədəninin ən böyük vəzi olub qarın boşluğunun üst qismində yerləşir, çəkisi 1100-1600 q., bədən çəkisinə nisbəti isə, 15-20 q/kq təşkil edir. Qaraciyər formaca mürəkkəb orqandır və təxminən oval və çəp şəkilində kəsilmiş yumurtanı xatırladır. Konsistensiyası yumşaq, kanlı orqan olan karaciyər qəhvəyi rənglidir.

Qaraciyorin corrahi anatomiyası dedikdo, bu orqanda corrahi oməliyyat aparmaq üçün bilinməsi mütlaq olan anatomik mə`lumatlar nəzərdə tutulur. Bu anatomik mə`lumatlara qaraciyərin orqanotopiyas1 (ətraf orqanlara münasibəti), qaraciyər bağları, damarları və axacaqları, qaraciyərin daxili arxitekturası-pay, sektor və seqment düzülməsi, aiddir ki, bunları bilmədən rezeksiya əməliyyatını həyata geçirmək mümkün deyil.

\section{ORQANOTOPIYASI}

Qaraciyərin yüxarı qabarıq səthi tamamən diafraqma ilə əhatə olunmuşdur və dolayı yolla ağciyərlərlə və ürəklə təmasdadır. Sol payın üsərində ürəyə məxsus çuxur vardır. Qaraciyərin aşağı visseral səthi, soldan sağa doğru baxdıqda mə’də, onikibarmaq bağısaq, öd kisəsi, çənbər bağırsağın sağ küncü, sağ böyrək və sağ böyrəküstï vəzə təmas edir.

Qaraciyər arxa səthi böyrəküstü vəzi, aşağı boş vena, aorta və qida borusu ilə təmasdadır. Qaraciyərlə periton boşluğu vasitəsi ilə təmasda olan orqanlar (diafraqmanın böyük hissəsi, mə’də və onikibarmaq bağısağın ön səthləri, çənbər bağırsaq, qida borusu və aorta) normal halda əməliyat vaxtı qaraciyərdən sərbəst ayrılırlar. Qaraciyərlə bağlar, periton və köşək 
birləşdirici toxumalar vasitəsi ilə birləşmiş orqanların (diafraqma, mə' də, onikibarmaq bağısaq, öd kisəsi, sağ böyrək və böyrəküstü vəzi, aşağı boş vena) ayrılması üçün isə, bu birləşmələrin kəsilməsi lazım gəlir. Patoloji proseslər nəticəsində sərbəst ayrilan və ayrılmayan orqanlarla qaraciyər arasında sıx bitişmələr əmələ gələ bilir.

\section{QARACIYYR BA ĞLARI}

Qaraciyər bă̆ları tək və ya ikiqat periton təbəqələrindən əmələ gəlmiş embrional bağırsaq müsariqəsinin törəmələridirlər. $\mathrm{Bu}$ bağlar qaraciyəri örtən peritonun qarın divarını və diafraqmanı örtən parietal peritona, oniki-barmaq bağırsağı və mə`dəni örtən visseral peritona keçməsi nəticəsində meydana gəlirlər. Ona görə də qaraciyər bă̆ları bir-birindən ayrı deyil, bütöv bir şəkildə olub bir-birinin davamını təşkil edir vo slaqali bölgalarə göra adlanırlar. Öndən arxaya doğru sıralanarsa : parietal periton पoraqvari vo girdo băg $\square$ sağ vo sol ön tac bağlar $\square$ üçbucaq bağlar $\square$ săg vo sol arxa tac bağlar $\square$ venoz bă̆ $\square$ kiçik piylik $\square$ visseral periton.

Qaraciyər ilə ətraf orqanlar arasındakı bağları ssas və əlavə bağlar olaraq iki qrupa ayırmaq olar. Osas bağlar (qaraciyərin girdə baği, oraqvari bağ, tac bağlar, üçbucaq bağlar, venoz bağ, qaraciyər-onikibarmaq bağ1 və qaraciyər mə'də bağı) daimi rast gəldiyi halda, əlavə bağlar (qaraciyər-böyrək bağı, qaraciyər-q1da borusu bağı, qaraciyər böyrəküstï vəzi baği) az hallarda görülür.

vardir.

Qaraciyər bağlarının bir çox anatomik, fizioloji və klinik əhəmiyyəti

1. Qaraciyər paylarının, seqmentlərinin ayırd edilməsində bağlar mühüm orientasiya rolu oynayırlar.

2. Bağlar qaraciyərin yerində tutulmasında iştirak edirlər.

3. Bağlar qaraciyərlə ətraf orqanlar arasında əlaqə yaradır.

4. Bağların içərisində olan qan və limfa damarları, sinir lifləri və limfa düyünləri qaraciyərin qidalanmasında, iltihabi və şiş proseslərinin yayılmasında mühüm rol oynayırlar. 
5. Әməliyyatlarda qaraciyəri və ya ətraf orqanları sərbəstləşdirmək üçün bu bağların kəsilməsi lazım gəlir.

Qarının ön divarı və diafraqma ilə qaraciyər arasında ikiqat peritondan ibarət olan bağın qaraciyər visseral səthinə birləşən hissəsi qaraciyərin girdə bağı (lig. teres hepaticus), diafraqma səthinə birləşən hissəsi isə, oraqvari (lig. falciforum) bağ adlanır. Bu iki bağ qaraciyərin sol payının III segment ilə IV seqment arasındakı sərhədi tə`yin edir. Qaraciyərin girdə bağının içərisində yerləşən embrional göbək venası normada tam, bə’zən də hissəvi şəkildə obliterasıya olunaraq, göbəklə qapı venasının sol şaxəsi arasında bir bağa çevrilir. Bu vena portal hipertenziyada açılaraq qapı venası ilə göbəkətrafı venalar və aşağı boş vena sistemi arasında kolleteral təşkil edir. Oraqvari bağ isə, difraqmatik səthdə sol qaraciyər venasının əsasına yaxın bölgəyə qədər gedir, burada periton səhifələri ayrılır, təkqatlı sağ və sol ön tac bağlara keçir.

Sağ və sol tac bağlar ön və arxa olmaq üzrə iki cütdür. Bu bağlar qaraciyərin arxasındakı təxminən rombşəkilli, peritonsuz sahəni əhatə edirlər. Hər iki ön tac bağları peritonsuz səthin sağ və sol kənarında, arxa tac bağlarına kəçən yerdə qalınlaşaraq, üçbücaq bağları əmələ gətirirlər. Arxa tac bağları isə, aşağı boş venanın ön səthində venoz bağa birləşir və kiçik piyliyə ( qaraciyər mə'də və qaraciyər-oniki barmaq bağırsaq bağına - QOİBB) keçir.

Böyük həcmli rezeksiyalarda qaraciyəri sərbəstloşdirmək üçün, qaraciyərin bu bă̆larını kəsmək lazımdır. Oraqvari, tac bă̆lar və girdə bağ içarisinda qan, limfa damarları va kapillyarları vardır. Sirrozda portal hipertenziya ila alaqadar bu kapillyarlar va kiçik damarlar genişlənirlar va kasilarkan ciddi qanaxmalara, limforreyaya va hidrotoraksa sabab ola bilirlar. Ona göra, sirrotik xəstalorda bu bağları kasorkan yetərli bağlama va koaqulyasiya lazım galir.

Qaraciyər-oniki barmaq bağırsaq (QOİBB) bağı ikiqat peritondan ibarət olub, qaraciyər qapısı ilə OİBB soğanağı böyük əyriliyi arasında yerləşərək, qaraciyərə daxil olan damarları (qap1 venası və qaraciyər arteriyası), qaraciyərdən çıxan öd axacaqlarını və limfa damarlarını örtür. Qapı elementləri adlanan bu əsas üçlünün QOİBB bağı içərisində yerləşmə ardıcıllığı sağdan sola və öndən arxaya doğru Axacaq-Arteriya-Vena 
şəkilindədir. Lobektomiyalarda uyğun tərəfin qapı elementlərini bağlamaq üçün QOİBB bağının ön səhifəsini ayırmaq lazım gəlir. Qaraciyərə gələn qanı tam dayandırmaq üçün Pringler üsulu- QOİBB bağının müvəqqəti s1xılmasından istifado olunur.

$\mathrm{Bu}$ bağın davamı olan qaraciyər-mə`də bağı venoz yarıq ilə mə`dənin kiçik əyriliyi arasında yerləşir və içərisində ümumi qaraciyər arteriyası, azan sinirin qaraciyər şaxələri və bə`zən də əlavə qaraciyər arteriyaları olur. Bu bağın qaraciyərə birləşdiyi venoz yarığın dibində ipşəkilli venoz bağ yerləşir.

Venoz bağ embrional dövrdə mövcud olan və qap1 venasının sol şaxəsi ilə aşağı boş vena arasında əlaqə yaradan venoz axacağın qalıntısıdır. Venoz bağ girdə bağ çuxurundan başlayır, arxaya doğru gedir, boş venanın sol kənarına birləşir. Bu bağ öndən kiçik piyliyə birləşir. Venoz bağ və yaryğ I seqmentin II seqmetdən ayırd edilməsində əhəmiyyətlidir. Bundan başqa, I seqmentin sərbəstləşdirilməsi üçün bu bağın kəsilməsi vacibdir.

\section{QARACIYYR DAMARLARI VÖ̈DAXACAQLARI}

Qaraciyərin qanla təhcizatının iki mühüm xüsusiyyəti vardır. Birincisi, qaraciyər həm arteriyal, həm də venoz qanla təhciz olunur. Íkincisi, qaraciyərə qan gətirən damarlarla çıxan damarlar ayrı-ayrı bölgədə yerləşirlər ki, bu da qaraciyərin iki "ayaqcığını" əmələ gətirir: qaraciyər qapısı və venoz ayaqcı̆̆ . Qaraciyər qapısından qaraciyər arteriyası və qapı venası daxil olur, öd axacaqları və limfa damarları isə, çıxır. Venoz ayaqcı̆̆ sol qaraciyər venaları təşkil edir. Bunlarla əlaqədar olaraq, əməliyyat vaxtı qanaxmanı yetərli dərəcədə dayandırmaq üçün hər iki ayaqcığın nəzarət altında tutmaq lazımdir.

$\ddot{U}$ mumi qaraciyor arteriyast

Ümumi qaraciyər arteriyası günəş kötüyünün üç şaxəsindən biri olub, mə`dəaltı vəzin yuxarı arxa kənarı ilə OİBB soğanağına doğru gəlir, burada mə`də-OİBB arteriyasını verdikdən sonra xüsusi qaraciyər arteriyası adlanır və QOİBB bağı içərisində qaraciyər qapısına daxil olur. Xüsusi qaraciyər arteriyası sağ mə`də arteriyası şaxəsini verdikdən sonra qaraciyər qapısında sağ va sol qaraciyər arteriyalarına ayrılır, bunlar isə, qaraciyər daxilində 
diğər portal elementlərlə birlikdə seqmentar şaxələrə ayrılırlar. Ümumi və xüsusi qaraciyər arteriyalarının magistral damarlardan bu şəkildə ayrılması və şaxələnməsi normal sayılır, 70-85\% halda rast gəlir. 15-30\% - hallarda bu damarlarda müxtəlif anomaliyalar, $46 \%$ hallarda isə, əlavə qaraciyər arteriyalarına rast gəlinir. Bunlardan ən çox rast gəlinənləri aşağıdakılardır:

I. Ümumi va xüsusi qaraciyar arteriyası anomaliyaları (20\%)

1. Arteriyanın çıxış yerinə görə anomaliyaları

* Ümumi qaraciyər arteriyası yuxarı müsraiqə arteriyasından ayrılır $(7 \%)$

* Ü̈mumi qaraciyər arteriyası hepatosplenik kötükdən ayrılır (6\%)

* $\quad$ Ümumi qaraciyar arteriyası birbaşa aortadan ayrılır (1\%)

2. Arteriyiaların olmaması və ya şaxələnməsində anomaliyalar

* Ümumi qaraciyər arteriyası yoxdur, sağ vo sol qaraciyər arteriyalart birbaşa aortadan ayrllır (4\%)

* Xüsusi qaraciyər arteriyast yoxdur, să̆ vo sol qaraciyər arteriyalart birbaşa ümumi qaraciyar arteriyasından va ya aortadan ayrllır (20\%)

1. Xüsusi qaraciyər arteriyası yoxdur, săg vo sol qaraciyər arteriyaları birbaşa ümumi qaraciyor arteriyasından, qastroduodenal arteriyanın ayrıldiğı yerdon çıxırlar vo hor ikisi qapı venasının önündo yerloşirlar (14\%). Buna “aş̆̆ ayrilma" deyilir.

2. Xüsusi qaraciyar arteriyası yoxdur, să̆ vo sol qaraciyər arteriyaları birbaşa ümumi qaraciyar arteriyasından (2\%) ve ya aortadan (4\%). çıxırlar, sağ şaxə qapı venasının arxasında yerlaşir, qastroduodenal arteriya sol şaxadan çıxır. Buna "erkon" ayrlma deyilir.

* Ümumi, xüsusi qaraciyər arteriyalarl, sağ va sol pay şaxəlari yoxdur qaraciyar yalnız alava arteriyalarla qidalanır - çox nadir.

II. Olava qaraciyar arteriyaları ekstrahepatik damar-axacaqlardak anomaliyaların on çox rast galonidir vo xəstəlorin yarısına yaxınında (46\%) müşahidə edilir. Bu anomaliyanın dah çox rast gəlməsi embrional qaraciyərin qan təhcizatı ilə əlaqədardır. Erkən embrional dövrdə qaraciyər üç embrional arteriya ilə qidalanır: sağ, orta və sol embrional arteriyalar. Sonrakı dövrlərdə 
sağ və sol embrional arteriyalar atrofiyaya uğrayır, orta arteriyadan isə, ümumi, xüsusi qaraciyər arteriyaları və onların şaxələri meydana gəlir. Đlavə qaraciyər arteriyaları açıq qalmış sağ və sol embrional arteriyalardır.

* Olavə sağ qaraciyər arteriyası (24\%) embrional sağ arteriyanın qalıntısı olub daha çox yuxarı müsariqə arteriyasından ayrılır (20\%), adətən qapı venasının arxasında gedərək sağ qaraciyər arteriyasına və ya şaxələrindən birinə açılır, daimi olaraq öd kisəsinə şaxə verir.

* Olavə sol qaraciyər arteriyası (30\%) embrional sol arteriyanın qalıntısı olub daha çox sol mə`də arteriyasından ayrılır (23\%), qaraciyər-mə'də bağında yerləşir, sol qaraciyər arteriyasına və ya saxələrinə açılır.

*Təxməinən $8 \%$ halda isə, həm sağ, həm də sol əlavə qaraciyər arteriyaları birlikdə rast gəlir.

Xostəlorin toxminon yarısında qaraciyor arteriyalarında müxtəlif çıxış vo şaxələnmo anomaliyalarına rast golinir ki, bunlardan on çox klinik ohomiyyotlilori alavo qaraciyər arteriyaları, ümumi qaraciyor arteriyasının “aşağı vo erkən” şaxələnməsi, yuxarı müsariqo arteriyasından çıxmasıdır.

\section{Qapı venasi}

Qapı venası yuxarı müsariqə və dalaq venalarının mə`dəaltı vəzi başının arxasında birləşməsindən əmələ gəlir və uzunluğu təxminən 5-8 sm, çapı 1-1,5 sm-dir. QOİBB bağı içərisində qaraciyər qapısına gələrək sağ və sol pay şaxələrinə ayrılır, bunlar isə, qarciyər daxilində seqmentar və paycıq şaxələri verir. Qap1 venası axacaq və arteriyadan arxada yerləşir və normal halda OİBB soğanağı ilə qaraciyər qapısındakı haçalanma arasındakı bölğəsinə böyük şaxələr açılmır ("şaxəsiz bölmə”). Nadir (3\% dən az) hallarda sağ və sol mə'də venaları, pankreatoduodenal venalar dalaq venasına və ya retropankreatik bölməyə yox, qapı venasının "saxəsiz bölməsinə" açilırlar.

Qapı venası arteriya vo axacaqdan arxada yerloşir, diametri hor ikisindon do böyükdür, QOBB bağı içindo adoton şaxəsiz olduğu üçün ayrılması asandır, lakin, divarı çox nazikdirvo asanlıqla zədələnə bilir. 


\section{Qaraciyor axacaqlart}

Să̆ vo sol qaraciyər axacaqları qaraciyər qapısında, arteriya və vena haçalanmaları arasında və hər ikisindən də öndə birləşərək ümumi qaraciyər axacağı, 1,5-2 sm sonra isə, öd kisəsi axacağı ilə birləşərək ümumi öd axacağı əmələ gətirir, bu isə, 12-BB soğanağı, yuxarı enən hissəsi və pankreas başı arxasından keçərək enən hissənin ortasında OİBB böyük məməciyinə tökülür. Normal halda supraduodenal hissədə (QOİBB bağ içərisində) öd axacaqları qaraciyər arteriyası və qap1 venasından öndə, retroduodenal hissədə isə, pankreatoduodenal arteriya torundan arxada yerləşir. Xoledoxu qidalandırıan iki xisusi arteriya axacaq boyunca saat 3 və 9 istiqamətində (medial və lateral divarları boyunca) yerləşirlər. Bunlar qanın çox hissəsini "aşağıdan"- pankreatoduodenal arteriyal tordan (60\%), az hissəsini isə, "yuxarıdan" - sağ və ya sol qaraciyər arteriyalarından (40\%) alırlar. Ona görə də, axacaqda işemiyanın önlənməsi üçün xoledox sərbəstləşdirərkən medial və lateral tərəflərdə ehtiyatlı olunmal1, xoledox mümkün qədər qaraciyərə yaxın kəsilməlidir.

Öd yollarının qaraciyərdən kənar hissəsinin anomaliyaları xəstələrin üçdə birində rast gəlinir. Bunlar öd kisəsinin, öd kisəsi axacağının qaraciyər axacaqlarının anomaliyalarıdır.

Xəstədə anomaliyaları ortaya çıxarmaq və bunların əməliyyat vaxtı təhlükəli olmasının qarşısını almaq üçün iki yol vardır:

1. Düzgün anatomik ayırma

2. Omaliyyatdan avval va ya amaliyyat vaxtı xolangio- va angioqrafiyalar, bə'zi hallarda ultrasəs müayinəsi

\section{Qaraciyərin limfa damarlart}

Qaraciyərdə bir-biri ilə s1x əlaqədə - zəngin kollateralları olan iki limfatik kələf vardır: dərin va sathi.

Dərin limfatik damarlar Disse (endotel ilə hepatositlər arasındakı sahə) sahəsindən başlayır ve böyük bir qismi qapı strukturlarını tə'qib edərək qaraciyər qapısındakı düyünlərə, bunlar isə, günəş kələfi limfa düyünlərinə 
və sisternlərə tökülürlər. Dərin limfatik damarların az bir qismi isə, qaraciyər venalarını tə'qib edərək boş vena ətrafındakı limfa düyünlərinə tökülürlər.

Səthi limfatik damarlar isə, kapsulaltı bölgədən, o cümlədən, öd kisəsi və ətrafından limfanı toplayır, əsasən kisəətrafı düyünlərə açılırlar. Bu limfarik kələf qaraciyər bağlarındakı limfatik kapillyarlarla diafraqmaüstü sahaələrlə əlaqəlidirlər. Rezeksiyadan sonra hidrotoraksın baş verməsində bu damarların rol oynadığı hesab edilir.

Limfatik sistem şişlərin yayılmasında olduğu kimi, portal hipertenziyalarda venoz sistemə köməkçi vəzifə də yerinə yetirir. Sirrozda və qaraciyər ödemlərində (iltihabi və sirkulyator) limfatik drenaj kompensator olaraq artır.

Belalikla, qaraciyarin bir-biri ila six alaqali sathi va darin limfatik sisteminin böyük hissosi qaraciyər qapısına, az bir qismi boş vena atrafı düyünlarə açılır va bu sistemin diafraqmaztrafi sistemlarla alaqasi vardir.

\section{Qaraciyor venalart}

Qaraciyər venaları qaraciyər parenximasında portal elementlərə çəp şəkildə (iki əl barmaqlarının iç-içə keçirilmiş vəziyyətinə bənzər şəkildə) yerləşən damarlar olub, qaraciyərin pay və sektorlarının sərhədlərinin müəyyən olunmasında həlledici rol oynayırlar. İki qrup qaraciyər venaları var: böyük yuxarı venalar və kiçik aşağı venalar.

Yuxarı üç vena- sağ, orta və sol venalardır. Bunlar qaraciyər çıxışında boş venaya açılırlar və qaraciyərin əsas venoz yükünü daşıyırlar. Qaraciyər venalarının aşağı boş venaya açıldığı yer "qaraciyər çıxışı", "venoz yəhər", "venoz qapı" kimi kəlmələrlə adlandırılır və burada venalar tac bağlarla six təmasda ola bilirlər.

Sağ qaraciyər venası qaraciyərin lateral (və ya arxa) və medial (və ya ön) sektorları arasındakı sərhəddə - xəyali sağ qaraciyər yarığında yerləşir. $\mathrm{Bu}$ vena $\mathrm{V}$-VIII seqmentlərdən venoz qanı toplayır, qaraciyər çıxışında boş venaya açılır. Venanın böyük hissəsi parenxima içərisindədir. Venanın boş venaya yaxın parenximasız hissəsi $8-15 \mathrm{~mm}$ olub bə'zən tac bağlarla fibroz bitişməli ola bilir. Ona görə də bu bölğənin ayrarkən və tac bağların boş venaya yaxın hissəsini kəsərkən diqqətli olunmaq lazımdır. 
Orta qaraciyər venası qaraciyərin sağ və sol payları arasındakı sərhədə - orta qaraciyər yarığında yerləşir. Bu venanın qaraciyər üzərindəki proyeksiyası Kantl (Cantle) xəttinə uyğundur ki, bu da aşağ boş venadan öd kisəsi yată̆ına çəkilən xəttdir. Orta vena sağ payın ön (və ya içəri) sektorundan (V və VIII seqmentlər) sol payın isə, IV seqmentindən venoz qanı toplayaraq boş venaya açılır. Orta vena əksər hallarda sol qaraciyər venası ilə birləşərək kötük halında, çox az hallarda isə, (3\%) sərbəst şəkildə boş venaya açılır.

Orta venanın iki çox mühüm klinik əhəmiyyəti var. Birincisi, əməliyyatönü dövrdə, rezeksiya vaxtı bu venanı ultrasəslə, tomoqrafiya ilə və ya birbaşa görərək pay və seqmentlər arasındakı sərhədləri tə’yin edilir. Íkincisi, lobektomiyalarda qalan payda venoz axını pozmamak üçün orta venanın qorunması çox vacibdir.

Sol qaraciyar venası qaraciyərin sol payında lateral və medial sektorlar arasındakı xəttdə yerləşmişdir. Bu venanın proeksiyası boş venadan qaraciyərin sol lateral kənarının ortasına çəkilmiş xətt üzrədir. Bu vena II və III seqmentlərdən daimi, 50\% hallarda isə, IV seqmentdən venoz qanı toplayaraq orta vena ilə əmələ gətirdiyi kötüyün vasitəsi ilə aşağı boş venaya açılır. Sol venanın $1 / 2$ halda rastgələn şaxəsi oraqvari bağ proeksiyasında olur, III və IV seqmentdən venoz qanı toplayır. Diğər vena proeksiyalarında olduğu kimi, bu venanı zədələməmək üçün kəsik oraqvari bağ xəttindən 0,5 1 sm kənarda aparılmalıdır.

Belalikla, qaraciyorin asas venoz qan toplayıcıları olan să̆, orta vo sol venalar qaraciyorin diafraqmal səthina yaxin vo portal elementlor çarpaz istiqamatdə yerlaşirlar, qaraciyardəki pay va sektor sarhadlarinin müəyyən olunmasinda mühüm ahəmiyyat kasb edirlar. Ultrasas va tomoqrafik müayinalardə bu venalar aşağı boş venadan çıxan "üçtelli yelpik” şəkilində görünürlar.

Qaraciyərin aşağ venaları qaraciyərin boş vena ilə təməsda olan arxa səthində, ən çox I və VI seqmentlərindən çıxan, sayı 2-20 olan kiçik venalardır. I seqmentdən əksər hallarda (70\%) bir vena çıxar. VI seqmentdən 
çıxan venalar bə'zi hallarda (25\%) nisbətən böyük diametrli ola bilir. Bu venaların aşağıdakı klinik əhəmiyyətləri vardır.

Să̆ lobektomiyalarda kasilmalari lazımdır.

VI seqment venası böyük olan hallarda, să̆ qaraciyar venasa bağlansa da VI seqmenti saxlamaq olar.

Baddi-Kiari sindromunda bu venalarin sayəsinda qaraciyardon venoz axın to'min edila bilir. Bu sindromda, I seqmentin venoz axını pozulmadı̆̆ı üçün seqment kompensator hipertrofiyaya uğrayır.

\section{QARACIYYRIN DAXILII ARXITEKTONIKASI VӘ SEQMENTAR ANATOMIYYASI}

Qaraciyər tərkib nöqteyi-nəzərdən üç əsas komponentdən ibarətdir: qap1 venası, qaraciyər arteriyası və öd axacaqlarını əhatə edən qapı elementləri, qaraciyər venaları və bunlar arasında yerləşən hepatositlərdən ibarət əsil parenxima. Müasir histoloji və morfoloji baxışlara və tədqiqatlara görə bu üç komponentin düzülüş və yerləşməsi müəyyən bir qanunauyğunluq üzrədir ki, bu da qaraciyərin daxili arxitektonikasının əsasını təşkil edir. Bu prinsipə görə:

* Qaraciyər bir-birinə çarpaz istiqamətdə yerləşən qapı elementleri və qaraciyər venalarından (iç-içə keçirilmiş əldəki barmaqların vəziyyətinə bənzər şəkildə) və bunlar arasında hüdudlu və düzgün bir şəkildə düzülmüş parenxima hüceyrə kütləsindən ibarətdir.

* Damar-parenxima əlaqəsi nəticəsində quruluş və funksional cəhətdən müstวqil hissalar meydana gəlir. Yə’ni, ilk baxışda bütöv görünən qaraciyər əslində bir çox müstəqil hissələrə - iki paya, bunlar dört sektora, bunlar səkkiz seqmentə, bunlar isə, milyonlarla payclqlara bölünürlər.

* Qaraciyar venalar paylar vo sektorlar arasindakı anatomik sarhadlari müayyan edir, portal elementler isa, pay, sektor va seqmentlarin funksional sarhadlarini ta'yin edir.

* Pay, seklor və seqmentlər fərdi qapı təhcizatına malikdirlər. Venoz axınları isə, adətən ortaqdır. 
* Qaraciyər venalarından keçən boylama, qapısını isə, köndələn kəsən üç müstəvi ilə qaraciyər dört sektora ayrılır. Qaraciyər qapısından boylama keçən frontal müstəvi ilə sektorlar seqmentlərə ayrılır.

Beloliklo, qaraciyor parenximasının corrahi anatomiyasının osasını toşkil edon seqmentar quruluşa göro qaraciyər sokkiz seqmentdon ibarotdir. Seqmentlorin qapı tohcizatı fordi, venoz axını iso, ortaqdır. Seqmentlorin anatomik sərrhədlori qaraciyər venalarından keçən üç çəp-sagital vo qapıdan keçən frontal müstəvilorlo müəyyən olunur. Seqmentlorin hoqiqi fizioloji sərhədlori iso, uyğun portal şaxənin bağlanması ilo müəyyən edilir.

Qaraciyər iki paydan ibarətdir: qaraciyər kütləsinin 2/3-nü təşkil edən sağ pay və 1/3-nü təşkil edən sol pay ${ }^{1}$. Paylar arasındakı sərhəd orta qaraciyər yarığı ilə müəyyən olunur. Bu yarıq xəyali olub, içərisində orta qaraciyər venası vardır və proyeksiyası aşağı boş vena ilə öd kisəsi yatağı arasında çəkilən xəttə uyğun gəlir. Bu paylarin hər birinin müstəqil qap1 sistemi və venoz axımı mövcutdur. Sağ payın qan təhcizatı qapı venası və arteriyasının sağ şaxələri, öd axını sağ qaraciyər axacağı vasitəsi ilə, venoz axını isə, sağ və orta qaraciyər venaları vasitəsi ilə həyata keçirilir. Bənzər şəkildə, qap1 venası və arteriyanın sol şaxələri, sol qaraciyər axacağı, sol və orta qaraciyər venaları vasitəsi ilə sol payın qan təhcizatı və öd axımı həyata keçirilir. Anomaliya və kapillyar damarlar nəzərə alınmazsa, sağ və sol payların portal elementləri arasında böyük əlaqələr mövcud deyildir.

Hər iki pay öz növbəsində iki sektora ayrılır və qaraciyərdə dört sektor ortaya çıxır: sağ payda - sağ medial ve lateral (və ya sağ ön və arxa) sektorlar; sol payda sol medial və lateral sektorlar. Qaraciyərin üç venası sektorlar arasındakı sərhədi müəyyən edirlər. Sektorlar uyğun qapı elementleri ilə təhciz olunurlar.

\footnotetext{
${ }^{1}$ Klassik anatomik twsnifatda qaraciywr dört paya ayrılır: sağ, sol, kvadrat vw quyruklu paylar. Bu twsnifatda qaraciywrin xarici orientrlwrinw wsas götürülmüşdür vw daxili arxitektonika- damar-parenxima wlaqwsi nwzwrw alınmamışdır. Anatomik kvadrat vw sol pay cwrrahi klasifikasiyada sol pay kimi qwbul edilir, quyruklu pay isw I seqment adlanaraq iki pay arasında, hwr ikisi ilw dw wlaqwsi olan bölüm kimi qwbul olunur.
} 
Sektorlar isə, seqmentlərə ayrılır və nəticədə qaraciyərin 8 seqmentdən ibarət quruluşu ortaya çıxır. Seqmenlərə bölünmə qaraciyərin cərrahi anatomiyasının vo hazırkı anatomik rezeksiyaların asasını təşkil edir. Seqmentlər təpələri qaraciyər qapısına yönəlmiş piramidə bənzər şəkildədir. Seqmentlər qaraciyərin diafraqmal səthindən baxdiqda saat əqrəbi istiqamətində spiralvari şəkildə düzülmüşdür və rum rəqəmləri ilə, işarətlənirlər. I-IV seqmentlər sol payda, V-VIII seqmentlər isə, sağ payda yeləşir. Seqmentlərin spiralşəkilli düzülüşü ilə əlaqədar olaraq I seqment ən aşağıda, VIII seqment isə, ən yuxarıda yeləşmişdir. Ona görə də, visseral səthdə VIII seqment, diafraqmal səthdə isə, I seqment görünmür.

Mərkəzindəki vena ətrafında radial hepatosit sütünlrından və periferində isə, qap1 elementləri olan poliqonal şəkildəki paycıq qaraciyərin ən kiçik morfo-funksional vahidi hesab olunur. Hepatosit sütünları arasındakı qan kapillyarları (sinusoid) qapı damarları ilə qaraciyər venoz damarları arasında davamlılıq yaradır, öd kapillyarları isə, öd yollarınn başlanğıcını təşkil edir. Bunlarla bərabər kapillyar endoteli ilə hepatosit sütünları arasında olan hüceyrəarası sahə (Disse sahəsi) qaraciyərin limfatik sisteminin başlanğıcını təşkil edir.

\section{Intrahepatik qapı elementlori.}

Qaraciyər qapısında əvvəlcə arteriya, sonra axacaq, ən axırda isə, qap1 venası sağ və sol şaxələrə arılır və bu şaxələr qaraciyərə daxil olur. Qaraciyər daxilində qap1 elementləri ümumi bir qulffla örtülmüsş şəkildə, təxminən eyni vaxtda şaxələnərək uyğun pay, sektor, seqment və paycıqlara yetişirlər. Qaraciyər daxilində q1lıfla örtülü olan arteriya vena və axacağa ədəbiyyatda “qapı üçlüyü”, “qapı elementləri”, “qapı kötükləri” kimi adlar verilir.

Qaraciyər daxilində qapı elementlərini örtən ümumi q1lıf Qlisson kapsulunun davamı olub paycıq şaxələrinə qədər uzanır. Qap1 elementlərindəki Qlisson q1lıfının bir çox klinik əhəmiyyəti vardır:

* Q1lıf ilə damar və axacaqlar yaxın təmasda oldukları üçün intrahepatik damar və axacaqların bir-birindən ayrılması çətinləşir.

* $\quad$ Parenximi kəsərkən bu elementler birlikdə tutulub bağlanır

* Q1lif ultrasəs müayinəsində portal elementlər ətrafinda hiperekoik qatın görünməsinə səbəb olur ki, bu da portal venaları qaraciyər venalarından fərqləndirməyə şərait yaradır. 
Qaraciyər daxilində sağ qapı venası, sağ qaraciyər arteriyası və să̆ qaraciyər axacağından ibarət "sağ qapı kötüyü" 1,5-2 sm olub təxminən horizontal-frontal istiqamətdə sağa doğru yönəlir və iki sektora uyğın şaxələrə ayrılır. Bu kötükdən 70-90 dərəcə altında vertikal istiqamətdə ayrılan ön şaxə sağ medial (və ya sağ ön) sektora daxil olur. Bu isə, öz növbəsində V seqment üçün ön, VIII seqment üçün isə, arxa şaxələrə ayrılır. "Sağ kötüyün" davamı kimi görünən arxa şaxə isə, lateral (və ya arxa) sektora yönəlir və öz novbəsində VI və VII seqmentlər üçün iki şaxəyə ayrılr. Bir çox hallarda seqmentar saxələr birbaşa olaraq əsas kötükdən ayrılır. Bu halda $\mathrm{V}$ seqment saxəsi öndə yuxarı, VI şaxə öndə sağa, VII şaxə arxada sağa VIII şaxə isə, arxada yuxarıya doğru yerləşir. Seqmentektomiyalar zamanı bu şaxələnmənin nəzərdə tutulması çox vacibdir.

Qaraciyərdaxili “sol qapı kötüyü” sağa nəzərən uzun, lakin çapı daha kiçik olub, kapsulaltı bölgədə yerləşir. Girdə bağ çuxuru səviyyəsində "sol kötük" iki şaxə verir. Önə doğru yönələn və medial sektor üçün birinci şaxə çox qisa olub girdə bağa birləşən yerdə haçalanır: sola uzanan şaxə III seqmentə, içəri və yuxarıya uzanan şaxə isə, IV seqmentə daxil olur. Bu bölgə intrahepatik damar və axacaqların qaraciyər səthinə ən yaxın və girdə bağ sayəsində asan tapılan olan bölgəsidir. Ona görə də, qaraciyər qapısında böyük axcaqlara müdaxilə imkansız olan hallarda öd yollarını drenaj etmək üçün III seqment axacağı burada tapılaraq drenaj edilir.

"Sol kötüyün" ikinci şaxəsi onun davamı şəkilində olub sol lateral sektora yönəlir ki, bu da II seqmentdən təşkil olunmuşdur.

I seqmentin venoz axını kimi, qapı təhcizatı da atipikdir. Bu seqment həm sağ həm də sol tərəfdən şaxələr alır.

Qaraciyərdaxili qapı elementlerinin yuxarıda göstərilən bu şaxələnməsi ilə yanaşı bir çox anomaliyaları da rast gəlməkdədir. Bunlardan klinik əhəmiyyəti olanları aşağıdakılardır.

- Să̆ payda seqmentar şaxələr birbaşa olaraq "sağ kötükdən” ayrılır. Seqmentektomiyalarda bu şaxələrin ayrıca tapılıb bağlanması lazım gəlir.

- Qaraciyərin să̆ vo sol payları arasında slaqə yaradan anomaliyalar. Normal halda qaraciyərin sağ və sol paylar bir-biri ilə kapillyarlar səviyyəsində və I seqment vasitəsi ilə əlaqəlidirlər və bu əlaqə çox zəif 
kompensator imkanlara malikdir. Ona görə də, bir tərəfin mağistral damar və ya axacağının tıxanma və ya bağlanması o payın nekroz və atrofiyasina səbəb olur. Təxminən 1/3 hallarda rast gələn anomaliyalar sağ və sol paylar arasında müəyyən əlaqə yaradır. Bu əlaqələr bə’zi hallarda müsbət rol oynayır, məsələn diğər tərəfin drenajı üçün faydalıdır, bə'zi hallarda, xüsüsən rezeksiyalarda ağırlaşmalara səbəb ola bilərlər. Bunlardan aşağıdakı ikisini qeyd etmək olar.

1. Xəstələrin 30\%-inə yaxınında V və VIII seqmentin öd axacaqları sağ qaraciyər axacağına yox, sol axacağın qapıya yaxın bölümünə aç1lırlar. Bunun iki böyük əhəmiyyəti var. Sol lobektomiyalarda sol qaraciyər axacağının qapıya yaxın bağlanması bu seqmentlərin öd axınını pozaraq atrofiya törədə bilər. Ona görə də, sol axacağı daha distalda bağlamaqla bu ağırlaşmanın qarşısı alına bilir. Diğər tərəfdən, qaraciyər qapısındakı inoperabl şişlərdə öd yolu dekompressiyası üçün III seqment drenajı əməliyyatı yerinə yetirilir. Bu anomliyanın mövcudluğı sayəsində qaraciyərin sağ payı da hissəvi olaraq drenaj edilir və daha çox qaraciyər toxuması qorunur.

2. Təxminən $20 \%$ hallarda IV seqmentin arteriyası sağ qaraciyər arteriyasından ayrilır. Sağ lobektomiyalarda arteriyanın bağlanılması IV seqmentdə nekroza səbəb ola bilir. $\mathrm{Bu}$ anomaliyanın ağırlaşmalarını iki sadə yolla önləmək olar. Birincisi, sağ kötüyü bağlamadan əvvəl s1xıb tutaraq qaraciyərdəki rəng dəyişikliyinə baxmaq lazımdır. IV seqmentdə rənk dəyişikliyinin olması anomaliyanı göstərir. İkincisi, kötüyü bütünlüklə yox, şaxələrini bağlamaq daha düzgündür. IV seqment saxəsi arteriyanın sol yanından çıxdığı üçün arteriyanı ayırarkən sağ tərəfdən ayırmaq, sağ şaxələri bağlamaq və sola toxunmamaq lazımdir. 


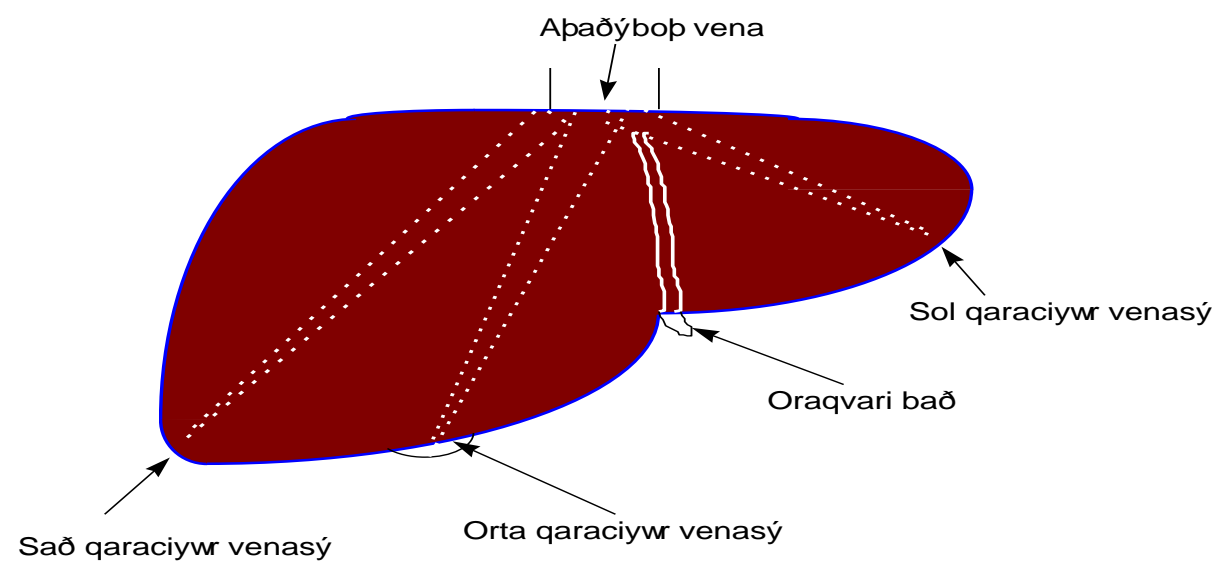

Şəkil 1.1 Qaraciyarin diafraqmal səthindən sxematik görünüşü

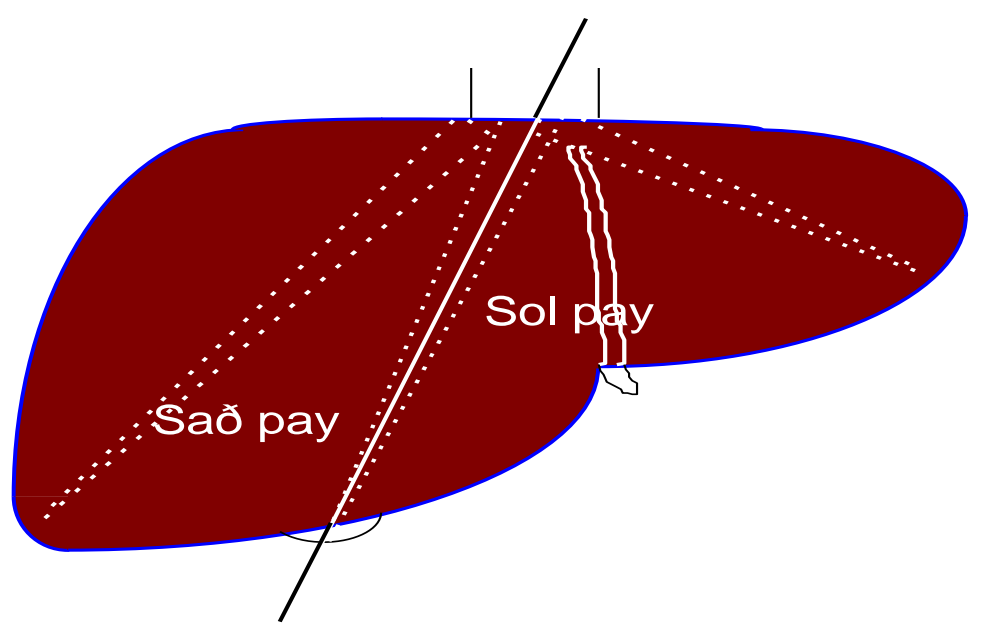

Şəkil 1.2. Qaraciyər paylarının diafraqmal səthindən sxematik görünüşü 


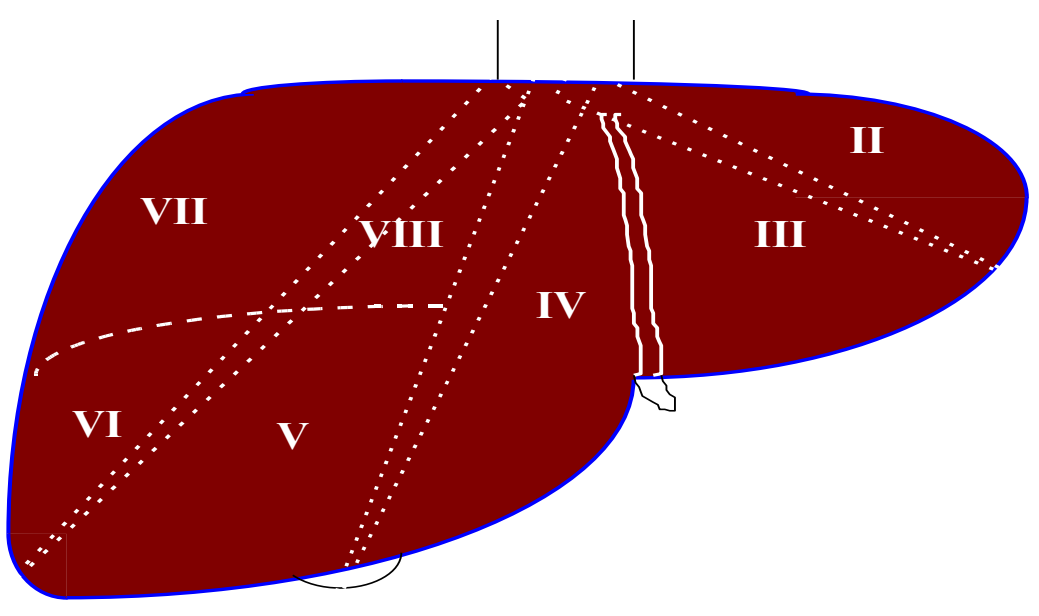

Şəkil 1.3. Qaraciyar seqmentlarinin diafraqmal sathindan sxematik görünüşü

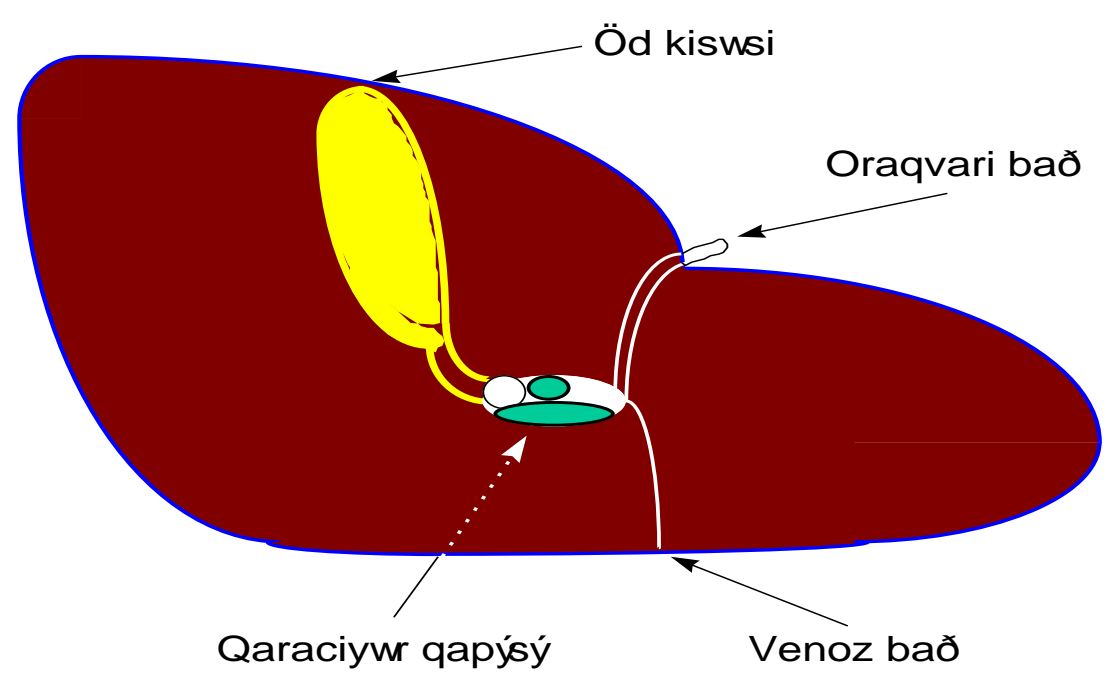

Şəkil 1.4. Qaraciyərin visseral səthindən sxematik görünüşü 


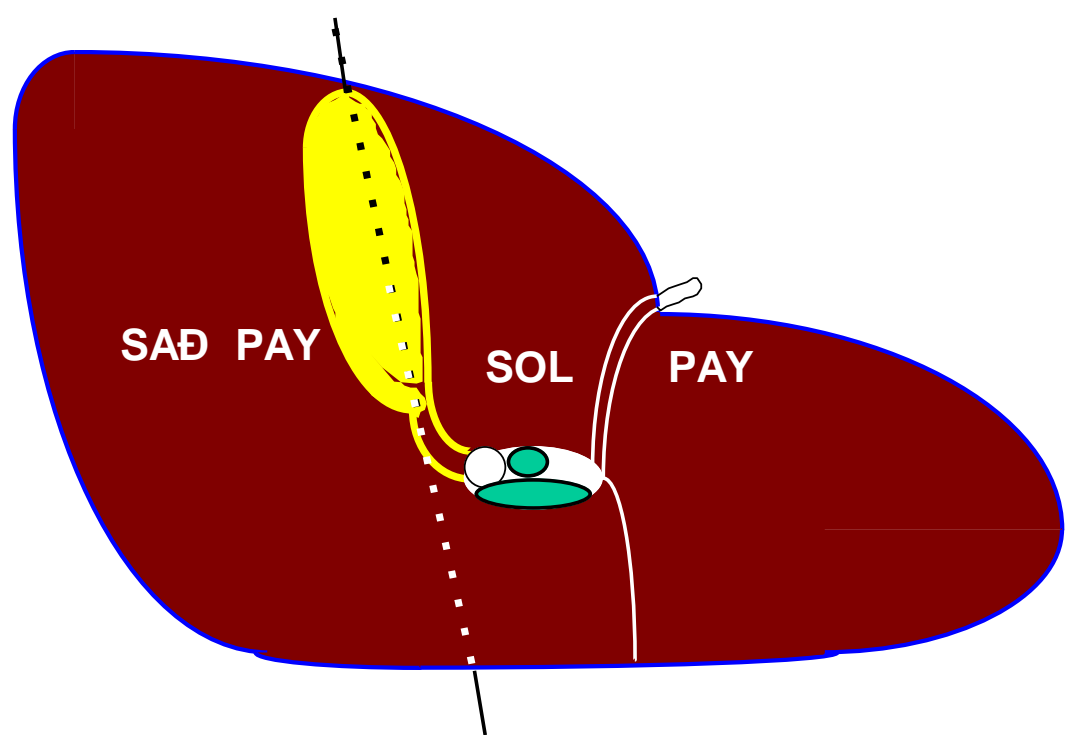

Şəkil 1. 5. Qaraciyar paylarının visseral səthindən sxematik görünüşü

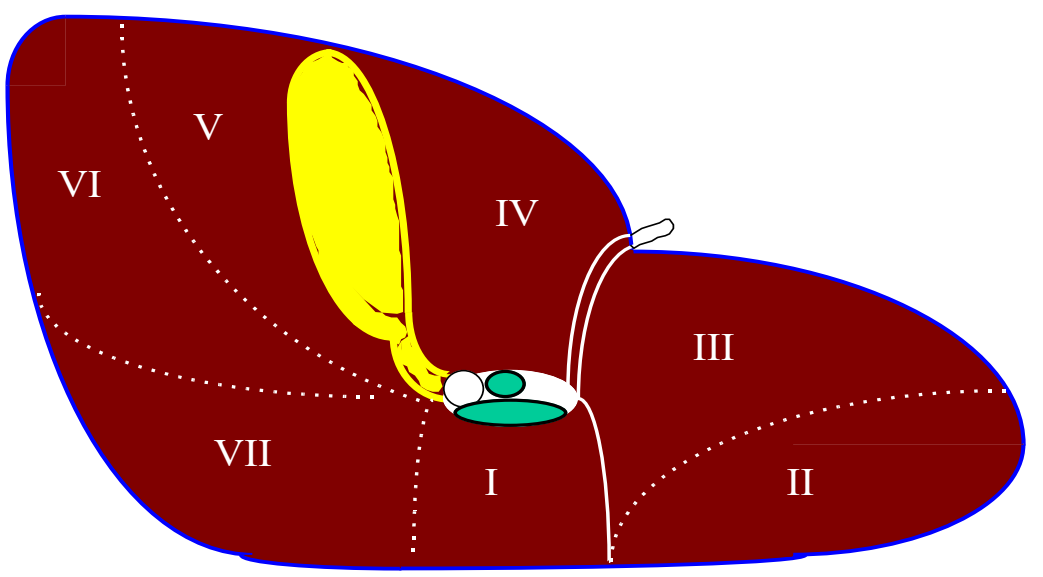

Şəkil 1. 6. Qaraciyər seqmentlarinin visseral sathindən sxematik görünüşü 


\section{Seqmentlor.}

I seqment qapı venası ilə aşağı boş vena arasında olan və piylik cibi dəliyinn tavanını təşkil edən hissədir. Köhnə nomenklaturaya görə buna quyruqlu pay deyirlər. Seqmentin əsas hissəsi boş venanın sol tərəfində və ona bitişikdir, quyruq adlanan kiçik bir hissəsi isə, boş venanın önündə yerləşir. Beləliklə, seqmentin ümümi şəkili "J” hərfinə bənzəyir. Bu seqment qaraciyərin diafraqmal səthindən görünmür. Sərhədlari, öndə qaraciyər qapısı, arxada aşağı bös vena, yuxarıda (intrahepatik) dorzal yarıq, solda venoz axacaq bă̆l, sağda iso, öd kisəsi yatağını boş vena ila birloşdiron xətt. I seqment yuxarıdan IV və VIII seqmentlərlə, sağda VII, solda isə, II və III seqmentlərlə həmsərhədir. I seqment qapı şaxələrini həm sağdan, həm də soldan almasına baxmayaraq, daha çox soldan alır. Ona görə də, sol paya aid edilir. Venoz axını aşağı qaraciyər venaları adlanan bir və ya bir neçə kiçik vena vasitəsi ilə birbaşa boş venaya açılır. Anotomik lokalizasiyonu və damar-axacaq xüsusiyyəti I seqnmentin bir çox klinik əhəmiyyətini müəyyən edir.

- I seqmentə müdaxilə etmək və onu çıxarmaq üçün qaraciyər paylarını ayırmaq lazım gəlir. Ona görə də, əksər hallarda birinci seqmentlə birlikdə qaraciyərin sol payını çıxarmaq lazım gəlir.

- Hər iki magistral damara yaxın olduğu üçün bu seqmentin şişləri qap1 və boş venaya daha tez invaziya edir və qisas zamanda inoperabl ola bilir.

- $\mathrm{Bu}$ seqment az da olsa, sağ və sol paylar arasında qap1 elementləri üzrə kollateral rolu oynayır.

- I seqmentin venoz axını sərbəst olduğu üçün yuxarı qaraciyər venalarının tıxanması (Baddi-Kiari sindromu) bu seqmentin venoz axınına tə'sir etmir. Ona görə də, bu seqment kompensator hipertrofiyaya uğrayır. Bununla yanaşı hipertrofiyanın diaqnostik əhəmiyyəti də vardır.

II seqment sol lateral sektoru təşkil edir, oraqvari bağdn solda və III seqmentdən arxada yerləşir. III seqment ilə sərhədi sol qaraciyər venası ilə tə’yin olunur ki, bu da boş venadan qaraciyərin sol lateral kənərının ortasına 
çəkilmiş xəttə uyğun gəlir. I seqmentlə sərhədini isə, venoz bağ müəyyən edir. Bu seqmentə aid qapı elementləri girdə bağ çuxurunda "sol kötükdən" ayrılır və arxaya, seqmentin mərkəzinə döğru yönəlir. Venoz axın isə, sol qaraciyər venasının II seqmentə aid şaxəsi vasitəsi ilə olur. Bu seqmentin çıxarılması zamanı sol qaraciyər venasının bağlanması lazım gəlir, bu isə, III seqmentin venoz axınını pozur. Ona görə də, çox vaxt II və III seqmentlər birgə çıxarılır. Bu iki seqment birlikdə qaraciyər həcminin $15 \%$ təşkil edirlər.

III seqment IV seqmentlə birlikdə sol medial sektoru təşkil edir. III seqment içəri tərəfdə IV, arxada isə, II seqmentlə təmasdadır. IV seqmentlə aralarındakı sərhədi oraqvari bağ, II seqmentlə isə, sol qaraciyər venası təşkil edir. Beləliklə, II və III seqmentlər oraqvari bağdan solda bayır tərəfdə qalırlar. Bu seqmentdən venoz axın sol qaraciyər venası vasitəsi ilə olur. III seqmentin qap1 elementləri girdə bağ çuxurunda sol orta sektora məxsus şaxəsindən ayrılır. "Sol kötükdən" ayrılan bu şaxə 0,5-1 sm önə doğru çıxdıqdan sonra haçalanaraq sola III seqmentə, içəri və yuxarıya IV seqmentə şaxə verir. Burada damar və axacaqlar səthə çox yaxın olurlar. Bununla yanaşı, girdə bağ sol qapı venasının buradakı haçalanma yerinə bağlanır. $\mathrm{Bu}$ iki cəhət III seqmentin damar və axacaqlarının asanlıqla tapılnasına şərait yaradır. Ona görə də, girdə bağ çuxuru bə’zən “ikinci qaraciyər qapısı” hesab edilir və III seqment axacaqlarından öd yollarını dekompressiya etmək üçün istifadə edilir. III seqmenti rezeksiyalarında kəsik oraqvari bağın sol kənarı ilə aparılır.

IV seqment sol payın ən böyük seqmentidir və qaraciyər həcminin $20 \%$ təşkil edir. Oski anatomik nomenklaturada kvadrat pay adlanan bu seqment III seqmentlə birlikdə sol median sektoru təşkil edir. Sol tərəfdə III seqmentlə, sağ tərəfdə V və VIII seqmentlərlə, aşağıda I seqmentlə həmsərhədir, arxada isə, boş venaya söykənir. Sərhədləri: diafraqmatik səthdə-solda oraqvari bağ, sağda isə, qaraciyər orta yarı̆̆1, visseral səthdə- sağda öd kisəsi, solda girdə bağ, aşağıda qaraciyər qapısı, arxada isə, (I seqmentlə sərhədi) dorsal yarıqdır. Dorsal yarıq qaraciyər venalarının boş venaya açıldığ 1 yerdən qaraciyər qapısına çəkilmiş xəttə uyğun gəlir. Diğər yarıqlardan fərqli olaraq burada vena olmur. IV seqmentin qapı təhcizatını girdə bağ çuxurunda "sol medial sektor kötüyündən” ayrılan 1-3 ədəd şaxə tə’min edir. Seqmentin venoz axını başlıca olaraq orta qaraciyər venası vasitəsi ilə olur. Sol qaraciyər 
venas $50 \%$ hallarda rast gələn və oraqvari bağa uyğun proeksiyadakı şaxasi ilə IV seqmentin venoz axınında iştiriak edir.

V seqment sağ payın medial (ön) sektorunun ön hissəsini təşkil edərək, öd kisəsinə qonşu və sağda yerləşir. Orta qaraciyər venası ilə IV seqmentdən, sağ qaraciyər venası ilə VI seqmentdən, qapı yarığ1 ilə VIII seqmentdən ayrılır. Seqmentin qap1 təhcizatı 0,5-1 sm uzunluğundak1 "sağ ön kötükdən" ayrılan vertikal və önə doğru yönələn 1-3 şaxə vasitəsi ilə olur. Bə’zən seqment şaxəsi birbaşa olaraq sağ əsas kötükdən ayrılır. Bu halda V seqment saxəsi vertikal və önə döğru yönəlmiş olur və sıxıldığında seqmentə uyğun sahədə rəng dəyişikliyi baş verir. Təxminən $30 \%$ halda V və VIII seqmentin öd axacaqları sağa yox, sol qaraciyər axacağına açılır. Venoz axın isə, həm orta, həm də sağ qaraciyər venaları sayəsində olur. Öd kisəsinə qonşu olduğu üçün öd kisəsi xərçəngi bu seqmentə daha tez yayılır və əməliyyat vaxtı bə'zən tək bə'zən də IV seqmentlə birgə çıxarılması lazım gəlir.

VIII seqment sağ ön sektorun arxa hissəsidir. Sağda orta qaraciyər venası, solda sağ qaraciyər venası, öndə qapı yarığı ilə hüdudlanır. Arxa tərəfdə boş venaya, öndə V seqmentə, sağda VII, solda isə, IV seqmentə söykənir. VIII seqment qaraciyər visseral səthində görünmür, diafraqmal səthdə isə, ən yüksəkdə duran və oraqvari çuxurun təşkilində iştirak edir. Qap1 təhcizatı birbaşa sağ və ya sağ ön kötükdən çıxan, arxa və yuxarıya gedən bir və ya bir neçə şaxələrlə olur. Venoz axını isə, sağ və orta qaraciyər venaları ilə tə'min edilir. "Dört tərəfdən bağlı" olması, sağ, orta qaraciyər və boş vena ilə six təması sayəsində VIII seqmentin sərbəst ç1xarılması ən çətin seqmentektomiyalardan sayılır.

VI seqment să̆ lateral sektorun ön hissəsini təşkil edir. Sağ qaraciyər yarığ1 ilə V seqmentdən, portal yarıq ilə VII seqmentdən ayrılır. Qap1 təhcizatı "sağ lateral kötükdən" ayrılan şaxələrlə olur. Sağ əsas kötüyün davamı kimi görünən lateral kötük ön kötükdən uzun olub VII seqmentə qədər uzanır və VI seqmentə bir bə’zən də iki və ya üç şaxə verir. Sağ əsas kötüyün sektoral şaxə vermədiyi, birbaşa seqmentar şaxələrə ayrıldığı hallarda VI seqment şaxəsi önə və sağa yönəlmiş olur. VI seqmentin ən əhəmiyyətli cəhətlərindən biri venoz axınıdır. VI seqmentin venoz axını əsasən sağ qaraciyər venası ilə olur. Aşağı qaraciyər venaları adlanan və sayı 2-dən 20-yə qədər ola bilən kiçik venalar da venoz axında iştirak edirlər. 
Təxminən 20-25\% hallarda bu venalardan biri böyük olub VI seqmentin venoz axınını qaraciyərin sağ venasına ehtiyac qalmadan tam tə'min edə bilir. $\mathrm{Bu}$ vəziyyətdə sağ qaraciyər venasını bağlayaraq, VII və diğər seqmentləri ç1xararaq, VI seqmenti saxlamaq və ekonomik rezeksiya etmək olar.

VII seqment sağ lateral sektorun arxa hissəsidir. Ön tərəfdə VI seqmentlə, sol tərəfdə VIII seqmentlə həmsərhədir. Sağ qaraciyər venası sol sərhədini , qap1 yarı̆̆ı isə, ön sərhədini müəyyən edir. Qap1 təhcizatı sağ lateral kötükdən ayrılan seqment şaxələri vasitəsi ilə, venoz axını isə, sağ qaraciyər venası isə, tə'min edilir.

Belalikla, qaraciyarin corrahi anatomiyasında bilinmosi vacib olan çəhatlar:

1. Qaraciyar băglart

- Bağlar qaraciyəri örtən peritonun qarın divarına və orqanlara keçməsi nəticəsində əmələ gəlir, bir-birinin davamıdırlar.

- Bağlar qaraciyərə daxil olan və çıxan böyük damar və axacaqları tam və ya hissəvi əhatə edirlər, qaraciyəri yerində tuturlar, içərisindəki kapillyarlar səviyyəsində qaraciyərlə ətrafdakı orqanlar arasında əlaqə yaradirlar.

- QOİBB bă̆ında portal elementlər var. Qaraciyər-mə’də bağında əlavə qaraciyər arteriyası ola bilir. Girdə bă̆ göbək venasinı əhatə edir və girdə çuxurda "sol qapı kötüyünün” şaxələndiyi yeri göstərir. Oraqvari bă̆ III və IV seqmentlərin sərhədini, və arxada üçbüçaqşəkilli oraqvari çuxuruda qaraciyər venalarının boş venaya töküldüyü yeri göstərir. Venoz bă̆ I və II seqmentlər arasındakı sərhədi göstərir.

- Qaraciyər rezeksiyalarında bağların birləşdirici, istiqamətverici əhəmiyyətləri nəzərə alınır. Rezeksiyalarda qaraciyəri sərbəstləşdirmək üçün bu bağlardan bə’zilərinin kəsilməsi lazım gəlir. Seqmentlər arasındakı sərhədi müəyyən etmək, qaraciyərdaxili və xarici damar və axacaqları tapmaq üçün bağların istiqamətvərici rolundan istifadə edilir.

2. Qaraciyərin qapı elementlari: damar va axacaqları 
- Qaraciyər həm arteriyal, həm də venoz qanla təhciz olunur. Qaraciyərə qan gətirən damarlarla çıxan damarlar ayrı-ayrı bölgədə yerləşirlər ki, bu da qaraciyərin iki "ayaqcı̆̆ını" əmələ gətirir: qaraciyar qapısı va venoz ayaqciğl.

- Ümumi qaraciyər arteriyası günəş kötüyünün üç şaxəsindən biri olub, mə`dəaltı vəzin yuxarı arxa kənarı ilə OİBB soğanağına doğru gəlir, burada mə`də-OİBB arteriyasını verdikdən sonra xüsusi qaraciyər arteriyası adlanır və QOİBB bağı içərisində qaraciyər qapısına daxil olur. Xüsusi qaraciyər arteriyası sağ mə`də arteriyası şaxəsini verdikdən sonra qaraciyər qapısında săg və sol qaraciyər arteriyalarına ayrilır.

- Xəstələrin təxminən yarısında qaraciyər arteriyalarında müxtəlif çıxış və şaxələnmə anomaliyalarına rast gəlinir ki, bunlardan ən çox klinik əhəmiyyətliləri əlavə qaraciyər arteriyaları, ümumi qaraciyər arteriyasının "aşağı və erkən” şaxələnməsi, yuxarı müsariqə arteriyasından çıxmasıdır.

- Ümumi və xüsusi qaraciyər arteriyaları bağlana bilər və bundan ağır qanaxmaları dayandırmaq üçün, və xərçəngin müalicəsində istifadə edilir.

- Qap1 venası arteriya və axacaqdan arxada yerləşir, diametri hər ikisindən də böyükdür, QOBB bağı içində adətən şaxəsiz olduğu üçün ayrılması asandır, lakin, divarı çox nazikdirvə asanlıqla zədələnə bilir.

- Xoledoxu qidalandırıan iki xisusi arteriya axacaq boyunca saat 3 və 9 istiqamətində (medial və lateral divarları boyunca) yerləşirlər. Bunlar qanın çox hissəsini "aşağıdan”- pankreatoduodenal arteriyal tordan (60\%), az hissəsini isə, "yuxarıdan" - sağ və ya sol qaraciyər arteriyalarından (40\%) alırlar. Ona görə də, axacaqda işemiyanın önlənməsi üçün xoledox sərbəstləşdirərkən medial və lateral tərəflərdə ehtiyatlı olunmalı, xoledox mümkün qədər qaraciyərə yaxın kəsilməlidir.

- Xəstədə anomaliyaları ortaya çıxarmaq və bunların əməliyyat vaxtı təhlükəli olmasının qarşısını almaq üçün iki yol vardır: düzgün 
anatomik ayırma; əməliyyatdan əvvəl və ya əməliyyat vaxtı xolangio- və angioqrafiyalar, bə'zi hallarda ultrasəs müayinəsi

\section{Qaraciyər venalart}

- Qaqaraciyərin əsas venoz qan toplayıcıları olan sağ, orta və sol venalar qaraciyərin diafraqmal səthinə yaxın və portal elementlərə çarpaz istiqamətdə yerləşirlər, qaraciyərdəki pay və sektor sərhədlərinin müəyyən olunmasında mühüm əhəmiyyət kəsb edirlər. Ultrasəs və tomoqrafik müayinələrdə bu venalar aşağı boş venadan ç1xan "üçtelli yelpik" şəkilində görünürlər. İki qrup qaraciyər venaları var: böyük yuxarı venalar və kiçik aşağı venalar.

- Să̆ qaraciyər venası qaraciyərin lateral (və ya arxa) və medial (və ya ön) sektorları arasındakı sərhəddə - xəyali sağ qaraciyər yarığında yerləşir. $\mathrm{Bu}$ vena V-VIII seqmentlərdən venoz qanı toplayır, qaraciyər çıxışında boş venaya açılır.

- Orta qaraciyər venası qaraciyərin sağ və sol payları arasındakı sərhədə - orta qaraciyər yarığında yerləşir. Bu venanın qaraciyər üzərindəki proyeksiyası Kantl (Cantle) xəttinə uyğundur ki, bu da aşa $\breve{g}$ boş venadan öd kisəsi yatağına çəkilən xəttdir. Orta vena să̆ payın ön (və ya içəri) sektorundan (V və VIII seqmentlər) sol payın isə, IV seqmentindən venoz qanı toplayaraq boş venaya açılır. Orta vena əksər hallarda sol qaraciyər venası ilə birləşərək kötük halında, çox az hallarda isə, (3\%) sərbəst şəkildə boş venaya açılır.

- Orta venanın iki çox mühüm klinik əhəmiyyəti var. Birincisi, əməliyyatönü dövrdə, rezeksiya vaxtı bu venanı ultrasəslə, tomoqrafiya ilə və ya birbaşa görərək pay və seqmentlər arasındakı sərhədləri tə’yin edilir. Íkincisi, lobektomiyalarda qalan payda venoz axını pozmamak üçün orta venanın qorunması çox vacibdir.

- Sol qaraciyər venasi qaraciyərin sol payında lateral və medial sektorlar arasındakı xəttdə yerləşmişdir. Bu venanın proeksiyası boş venadan qaraciyərin sol lateral kənarının ortasına çəkilmiş xətt üzrədir. Bu vena II və III seqmentlərdən daimi, $50 \%$ hallarda isə, IV seqmentdən venoz qanı toplayaraq orta vena ilə əmələ gətirdiyi kötüyün vasitəsi ilə aşağı boş venaya açılır. 
- Qaraciyər venalarının aşağı boş venaya açıldığı yer "qaraciyər çıxışı”, "venoz yəhər", "venoz qapı" kimi kəlmələrlə adlandırılır və burada venalar tac bağlarla six təmasda ola bilirlər.

- Qaraciyərin aşağl venaları qaraciyərin boş vena ilə təməsda olan arxa səthində, ən çox I və VI seqmentlərindən çıxan, sayı 2-20 olan kiçik venalardır. I seqmentdən əksər hallarda $(70 \%)$ bir vena çıxar. VI seqmentdən çıxan venalar bə’zi hallarda (25\%) nisbətən böyük diametrli ola bilir. Bu venaların aşağıdakı klinik əhəmiyyətləri vardır: săg lobektomiyalarda kasilmalari lazımdır; VI seqment venası böyük olan hallarda, săg qaraciyər venasa bağlansa da VI seqmenti saxlamaq olar; Baddi-Kiari sindromunda bu venalarn sayasinda qaraciyardan venoz axın ta'min edila bilir. Bu sindromda, I seqmentin venoz axını pozulmadı̆̆ $\ddot{u} c ̧ u ̈ n ~ s e q m e n t ~ k o m p e n s a t o r$ hipertrofiyaya uğrayır.

4. Qaraciyzrin limfa damarlart.

- Qaraciyərin bir-biri ilə six əlaqəli səthi və dərin limfatik sisteminin böyük hissəsi qaraciyər qapısına, az bir qismi boş vena ətrafi düyünlərə açılır və bu sistemin diafraqmaətrafı sistemlərlə əlaqəsi vardir.

5. Qaraciyərdaxili arxitektonika və seqmentar quruluş.

- Prinsipcə qap1 elementlərindən, qaraciyər venalarından və parenximadan ibarət olan qaraciyərdə bu üç element xüsusi qanunauyğunluqla düzülmüşdür.

- Qapı elementləri ümumi q11ıfla örtülü şəkildə, qaraciyər venaları bunlara çarpaz şəkildə, parenxima isə, venalar ətrafında radial şəkildə düzülmüşdür.

- Qaraciyərdə damar-axacaq və parenxima münasibəti nəticəsində payciq, seqment, sektor və pay kimi morfoloji və funksiyonal cəhətdən sərbəst parenxima bölümləri əmələ gəlmişdir.

- Qaraciyərdəki pay, sektor və seqmentlərin sərhədlərinin müəyyən olunmasında üç qaraciyər venası, qapı elementlərinin proyeksiyaları və bunlardan keçirilən "xəyali" müstəvilərdən istifadə olunur. 
Qaraciyər venalarından keçirilən üç çəp-sağital müstəvi ilə qaraciyər dört sektora ayrılır: sağ lateral və medial, sol medial və lateral. Qap1 elementlerinin proyeksiyasından keçirilən frontal müstəvi isə, sektorları seqmentlərə bölür.

- $\mathrm{Bu}$ üç çəp-sağital və bir frontal müstəvi ilə bölünmə nəticəsində qaraciyər zirvələri qapıda birləşmiş, əsasları diafraqmatik üzdə yerləşmiş piramidlərdən təşkil olunmuş ikiqatlı yelpiyi xatırladır.

- Pay, sektor və seqmentlərin dəqiq sərhədləri uyğun qapı şaxəsinin bağlanmasından sonra əmələ gələn hipoksiya bölgəsinə görə tə’yin edilir.

\section{ӘDӘВIYYAT}

1. Balakişiyev K. İnsanın normal anatomiyası. Bakı 1969

2. Bismuth H, Ciche L. Surgical anatomy and anatomical surgery of the liver. In: Blumgart LH, ed. Surgery of the liver and biliary tract. Edinburgh: Churchill Livingstone, 1994: 3-9.

3. Bernard L, G.G.Jamison. Modern operative techniques in liver surgery. Tokyo 1993.

4. Grant's Atlas of Anatomy. Williams \& Wilkins. 1997.

5. Ger R. Surgical anatomy of the liver. In. Surg Cln North Am 1989:69:2:179-192

6. Ratych R.E., Smith G.W. Anatomy and physiology of the liver. In: Shackelfrd's Surgery of the alimentary tract.Saunders Company, 1996:357-373

7. Юapkin V.S. Rezekcig peзeni. Moskva 1967.

8. Sinelınikov. Atlas anatomii zeloveka. Moskva 1981.

9. Takayama T, et al. Segmental liver resections, present and future-caudate lobe resection for liver tumors. Hepatogastroenterology. 1998 JanFeb;45(19):20-3 


\section{Bölüm}

\section{QARACIYYRIN MÜAYINO ÜSULLARI}

Diğər orqanlarda olduğu kimi qaraciyərin müayinə üsulları da bu orqanın funksional və morfoloji cəhətdən öyrənilməsinə əsaslanmışdır. Cərrahi nöqteyi-nəzərdən baxdıqda isə, müayinə iki hədəfə istiqamətlənmişdir. Birincisi, qaraciyərdə yerli törəmə va zadələnmələrə ki, bunlar adətən cərrahi müdaxilə tələb edirlər. Íkincisi isə, qaraciyər parenximasının vəziyyətinin araşdırılmasına. Hər iki halda da, aşağıdakı üç əsas məsələnin həll edilməsi lazım gəlir:

1. Qaraciyarda yerli zadalanma va parenximada diffuz dayişiklik varmı?

2. Qaraciyarda yerli zadalanma va parenximada diffuz dayişikliyin tabiati nadir?

3. Qaraciyarda yerli zadalanma va parenximada diffuz dayişikliyin ölçüsü va daracasi na qadardir?

Bu suallara cavab vermə imkanı eyni zamanda müayinə üsulunun faydalılıq dərəcəsini də müəyyən edir.

Klinik (anamnez, obyektiv müayinə), görüntüləmə üsulları, funksional göstəricilər, immunoloji, hormonal müayinələr və s. kimi üsulların düzgün və ardıcıl tətbiqi qaraciyər xəstəliklərinin diaqnozunun və rezektabelliyinin müəyyən edilməsində vacib məsələdir. 


\section{GÖRÜNTÜLOMӘ ÜSULLARI}

Görüntüləmə üsulları qaraciyəri anatomik-morfoloji cəhətdən göstərən vasitələrdir. Bu üsullar başlıca olaraq aşağıdakılar haqqında mə'lumat verir:

* Qarciyərin ölçüsü

* Qaraciyər parenximasının quruluşu

* Qaraciyərdə qan axını və öd axınının vəziyəti

* Q Qaraciyərdə böyük damar və axacaqların vəziyyəti

* Qaraciyərdə yerli zədələnmənin (və ya törəmə) yeri, sayı, ölçüsü-yayılma dərəcəsi

* Törəmənin daxili quruluşu

* Törəmənin damar və axacaqlara münasibəti

* Törəmənin qan təhcizat1

Hazırda qaraciyəri göstərmək üçün müxtəlif üsullar mövcuddur. Bunlardan ən çox istifadə ediləni və yüksək həssaslığa malik olanları ultrasəs müayinəsi və tomoqrafiya üsullarıdır.

\section{ULTRASӘS MÜAYİNəSİ (USM)}

Ultrasəs müayinəsi səs dalğalarının bir mühitdən diğərinə keçdikdə əks olunma prinsipinə əsaslanmışdır. Mühitlərin fiziki xüsusiyyətləri nə qədər müxtəlif olarsa əks olunma, udulma da o qədər müxtəlif olur ki, bu da görüntünün daha aydın olmasını tə'min edir. Klinik praktikada toxumaların səs dalğalarını əks etdirmə qabiliyyəti "ekogenlik" adlanır.

Parenximatoz orqanların (böyrək, qaraciyər, dalaq) normal halda ekogenitesi izoekoik olaraq qiymətləndirilir. Ona görə də bir orqanın ekogenitesini qiymətləndirmək üçün diğər orqanla müqayisə etmək lazımdır.

Maye mühitlərdən dalğalar asanlıqla keçir, az udulur və zəif əks olunur. Ona görə də maye mühitlər anekoik (ekranda qara rəngli) görünürlər. 
Öd kisəsi, qan damarları, sidik kisəsi, kistlər maye mühitli olduqları üçün anekoik görünürlər.

Maye ilə zəngin toxumalar parenximatoz orqanlara nəzərən hipoekoik görünürlər. Maye mühitləri (anekoik, hipoekoik) maye-bərk mühitlərdən fərqləndirmək üçün dalğaların keçid sərhədindən əks olunma dərəcəsinə baxılır. Maye mühitlə parenximatoz mühit arasında sıxlıq çox fərqli olduğu üçün, keçid sərhədində əks olunma daha yüksək olur, keçiricilik azalır, dərin qatlardakı toxumalar görünmür ("akustik kölgə”). Mayedən zəngin bərk toxumalar izoekoik toxumalardan az fərqləndiyi üçün əks olunma nisbətən az olur, dalğalar dərin qatlara keçərək buradakı toxumaları da göstərir. Sərt və az mayeli toxumalar (sümük, fibroz toxuma, daş) yüksək əksetdirmə və az keçiricilik göstərdikləri üçün hiperekogen görünürlər (ekranda ağ rəmgli), dərindəki toxumalar isə, görünmür (akustik kölgə).

Qaz mühitin sıxlığg diğər mühitlərdən çox fərqləndiyi üçün sərhəddə əksolunma yüksək, keçiricilik isə, zəif olur. Ona görə də görüntü alınmır. Bu xüsusiyyət USM-in ən yetərsiz cəhətidir və qarında və ya bağırsaqlarda qaz olduğu hallarda müayinə edilə bilmir.

USM-də normal qaraciyər homogen, dalaq və böyrəklərə yaxın ekogen (izoekoik) görünən parenximadan ibarət olub, içərisindəki qaraciyər venaları və qapı venaları anekoik görünür.Qaraciyər venalarından fərqli olaraq portal elementlər Qlisson kapsulu ilə örtülü olduğu üçün ətraflarında hiperekoik dairə görünür. Böyüməmiş intrahepatik öd axacaqları ayırd edilmir. Xarici öd yolları (xoledox, öd kisəsi), qapı venası və aşağı boş vena aydın seçilir. Qaraciyərin orta körpücük xətti üzrə kranio-kaudal ölçüsü 1314 sm təşkil edir. $\mathrm{Bu}$ ölçünün 16 sm-dən çox olması hepatomeqaliyanı göstərir.

Qaraciyərdəki xəstəliyin USM-də aşkar edilməsi patoloji prosesin toxuma ekogenliyini nə dərəcədə dəyişdirdiyindən asılıdır. Diffuz ödem, qan təhcizatında artma (kəskin hepatit, Baddi-Chiari sindromu, rezeksiyadan sonrakı ilk günlər, kollivikasyon nekroz və s. ) qaraciyərin hipoekoik görünməsinə səbəb olur. Diffuz hiperekoik görüntü sirroz, xronik hepatit, fibroz, yağlı qaraciyər üçün xarakterikdir. 
USM diffuz qaraciyər xəstəliklərini bir-birindən ayırmada mükəmməl deyildir. Bunun üçün əlavə müayinələrə ehtiyac vardır.

Yerli zədələnmələrin (törəmələrin) aşkar edilməsində USM çox əhəmiyyətli bir vasitədir. Qaraciyərdə $1 \mathrm{sm}$-dən böyük törəmələrin 80-90\% aşkar edilməsinə imkan verir. USM-in ən mühüm cəhətlərindən biri də törəmənin kistik yoxsa, toxumalı (solid) olduğunu ayırd etməsidir. Kistik törəmələr anekoik və ya hipoekoik, toxumalı törəmələr isə, tərkibindən asılı olaraq hipo- və ya hiperekoik görünürlər. Törəmələr tərkibindəki toxumaların həmcins olub olmadığına görə homogen və ya heterogen görünə bilərlər. Anadangəlmə kistlər incə divarlı, anekoik, homogen görünürlər. Exinokokk kistləri qalın divarlı (fibroz qat), an-, hipoekoik olub içərisində xitin qatı (ikiqatlı divar, "yun yumağı" görüntüsü) və q1z qovucuqları (arı pətəyi” görüntüsü) görünür. Neoplastik kistlər isə, qalın, kələkötür divarlı olub, şiş toxuması kist içərisinə papillamatoz çıxıntı şəklində görünür.

Hiperplastik törəmələr (birincili, ikincili şişlər, sirrotik düyünlər) isə, adətən hipoekoik görünürlər. Törəmədə fibroz toxumanın və nekrozun olması heterogen görünməsinə səbəb olur. Fokal nodular hiperplaziyada mərkəzində çapık toxuma olduğu üçün hiperekoik mərkəzi olan hipoekoik düyün şəklində görünür. Böyük hemangiomalar, hepatosellular karsinomalar, metastatik şişlər heterogen görünürlər. Hepatik adenoma və sirrotik düyünlər homogen hipoekoik görünürlər. Xoş xassəli şişlər ətraf damarlara "itələmə" effekti, bəd xassəli şişlər isə, "invaziya" effekti törədirlər.

Birləşdirici toxuma və kalsifikasyonu olan toxumalar hiperekoik görünürlər. Kiçik hemangiomalar, vərəm, brusellyoz düyünləri, yaralanma və abseslərdən sonrakı çapıq toxuma hiperekoik görünür.

USM ilə qaraciyərdaxili və xarici öd yolları xəstəlikləri, xüsusən genişləmə, daş kimi patologiyalar 85-95\% hallarda işkar edilir.

USM əməliyyat vaxtı qaraciyər venalarının yerini, törəmələrin sərhədlərini, xarakterini və rezeksiya xəttini dəqiq müəyyən etməkdə cərrah üçün çox faydalı köməkci vasitədir.

Beləliklə, qaraciyərin cərrahi xəstəliklərində USM-in aşağıdakı üstünlükləri vardır:

* Asandır, noninvazivdir 
* Hər zaman, hər yerdə müayinə aparıla bilər

* Törəmənin toxumalı, yoxsa kistik olduğunu ayırd edə bilir

* Kiçik ölçülü törəmələri aşkar edə bilir.

* Öd yollarında genişlənmə, daş olub olmadığını yüksək dəqiqliklə göstərə bilir.

Bununla yanaşı aşağıdakı bir neçə əksik cəhətləri də vardır:

* Qarın boşluğunda və bağırsaqlarda aşırı qaz olduqda müayinə mümkün olmur

* Qaraciyərin diffuz xəstəliklərinin və törəmələrinin təbiətini müəyyən etmə dəqiqliyi çox yüksək deyildir (60-70\%).

* Damarların müayinəsindo, xüsusən damarlarla öd axacaqları arasında fərqi müəyyən etməkdə mükəmməl deyildir. Bunun üçün əlavə doppler USM-ə ehtiyac vardır.

* Müayinə edən həkimin subyektiv fikri müayinənin nəticələrinə tə'sir göstərə bilir.

\section{DOPPLER USM}

Axan mayenin dalğa əks olunmasına göstərdiyi tə'sir doppler effekti adlanır. Ultrasəs dalğalarının damarda axan qandan əks olunması doppler USM-in iş prinsipidir. Qan axınının sür'əti və xarakterindən asılı olaraq effekt dəyişir.Doppler USM vasitəsi ilə iki görüntü eynivaxtlı alınır: damar görünür və axının sür'əti tə’yin olunur. $\mathrm{Bu}$ üsul damarların müayinəsində əhəmiyyətli yer tutur, hətta bir çox hallarda angioqrafiyanı əvəz edir.

Doppler USM qaraciyərdaxili və xarici damarlarda qanın axın sür'ətini, istiqamətini, xarakterini, damarın diametrini, damardaxili tromb, invaziyaları, parenximada qan təhcizatını tə’ yin etməyə imkan verir. Şişlərin damara invaziyasının müəyyən edilməsi onların yayılma dərəcəsini müəyyən etmədə çox vacibdir. Qaraciyərdaxili damarları genişlənmiş öd axacaqlarından fərqləndirmək üçün doppler USM çox qiymətli noninvaziv 
metoddur. Qan damarlarından fərqli olaraq öd axacaqlarında axın zəif olduğu üçündoppler effekti ortaya çıxmır. Diğər tərəfdən arteriya və venalarda qan axını sür'əti fərqli olduğu üçün bir-birindən ayırmaq olur. Hemangiomalar və arterio-venoz fistulları da doppler USM vasitəsi ilə tə’yin etmək mümkündür. Kistləri toxumalı törəmələrdən ayırmaq üçün də doppler USM qiymətli üsuldur. Toxumada qan axını olduğu üçün doppler effekti yaranır, kistik törəmələrdə isə, bu effekt olmur.Doppler USM ilə toxumalarda qanın axın sür'əti ilə yanaşı qan axınına müqaviməti də hesablamaq olur ki, bu da köçütrülmüş orqanların qan təhcizatını, rəddetmə reaksiyasını müəyyən etmək üçün çox vacibdir.

Ümumiyyətlə, USM-in bir çox əksik cəhətləri, xüsusən, damarları və qan təhciztını araşdırmadakı əksikləri doppler USM vasitəsi ilə aradan qaldirılır:

* İntrahepatik və ekstrahepatik öd yollarını damarlardan ayırmağa imkan verir.

* Arteriya və venaları, arterio-venoz fistulları müəyyən etməyə imkan verir.

* Qapı venasında və böyük şaxələrində, qaraciyər venalarında, aşağ1 boş venada qan axınının istiqamətini, sür’ətini, diametrinin, şiş invaziyasının, trombun olmasını müəyyən etməyə imkan verir.

* Törəmələrdə qan dövranı səviyyəsini müəyyən etməyə imkan verir. $\mathrm{Bu}$ isə, kistik törəmələri toxumalı törəmələrdən ayırmağa, törəmələrin, hipo-, hipervaskular olduğunu, nekrotik toxumaları müəyyən etməkdə çox faydalıdır.

* Normal halda qapı venasının diametri mm, qan axını sür'əti mm/sn, istiqaməti isə, qaraciyərə doğrudur (hepatopedal).

\section{BILGISAYARLI TOMOQRAFIYA}

Bilgisayarlı tomoqrafiya (BT) üsulu toxumanın vahid həcminin (sahəsinin yox) Rentgen şüalarını keçirmə qabiliyyətinə əsaslanır. Hər vahid həcmdən keçən şüalar ayrı-ayrılıqda bilgisayar vasitəsi ilə hesablanır. Nəticədə, adi rentgendən fərqli olaraq hər səviyyədəki toxumanın 
görüntüləri üst-üstə düşməyərək ayrı-ayrılıqda görünür. Kubun müstəvidəki şəkli kvadrat olduğu kimi, orqanın hər vahid həcmi, tomoqrammada vahid sahəyə uyğun gəlir. Rentgen şüalarına keçiriciliyi fərqli olan toxumalar dəqiq görünə bilirlər.

Qaraciyərin BT müayinəsində adətən 0,5-1 sm qalınlığında kəsiklər edilir. Ovvəllər BT ilə ən çox horizontal kəsiklər aparılaraq "Piraqov kəsikləri” şəklində görüntü əldə edilirdi. Hazırda mövcud olan BT-larla vücudun müxtəlif müstəvilər üzrə-sağital, frontal və çəp kəsiklər üzrə də görüntüləri alına bilir.

BT-də toxumanı qiymətləndirmək üçün densimetrik, yə’ni sıxlıq (Rentgen şüalarını keçirmə qabiliyyəti) göstəricisindən istifadə edilir. Toxumaların sıxlığı Haunsfeld əmsalı ilə ölçülür ki, bu da toxumanın suya nəzərən Rentgen şüalarını nə qədər udduğunu göstərir. Haunsfeld şkalasında suyun udma əmsalı sıfır qəbul edilir. $\mathrm{Bu}$ göstəricinin hesablanması sayəsində görüntüsü bir-birinə bənzəyən toxumaları ayırmaq mümkündür. Məsələn, periton içərisində qan və assitik maye tomoqrafik şəkillərdə eyni görünür. Lakin bunların densimetrik əmsalları fərqlidir. Densimetrik əmsalı 40 vahiddən az olan mühitlər maye və yă̆ toxumasıdır, 40-dan yüksək olanlar isə, toxumalı törəmələrdir. Normal qaraciyər toxumasinın dansimetrik əmsalı 50-70 vahid, öd kisəsinin 10-20 vahid təşkil edir.

Hazırda BT-nin bir neçə üsulu istifadə edilir. Bu üsullar prinsipal olaraq iki qrupa ayrılır: nativ (kontrastsız) və kontrastlı. Kontrastsız BT-də əsas göstərici toxumanın dansimetrik xüsusiyyətidir. Kontrastlı üsullarda isə, əsas göstərici toxumanın kontrastlaşma və kontrastı tutma xüsusiyyətidir. Kontrastlı BT müayinənin kontrastın xarakteri və çəkilmə müddətindən asılı olaraq erkən, kecikmiş, yüksək dozlu, kalıcı, dinamik, angioqrafik metodları vardır.

Kontrast maddə damara, bağırsaqlara, və ya boşluqlara verilərək bu orqanların vəziyyəti qiymətləndirilir. Kontrastlı BT ilə qaraciyərdaxili və xarici damarlar aydın görünür, parenximanın və törəmələrin qan damarları təhcizatı qiymətləndirilə bilir. Normal qaraciyər toxuması kontrastlı və kontrastsız tomoqrafiyalarda homogen görünür, dansimetrik əmsalı 50-70 vahid təşkil edir. Kistlər qan təhcizatı olmadığı üçün kontrastsız görünür. Şiş toxuması kontrastsız üsulda normal qaraciyərə görə hipodens, kontrastlı 
üsullarda isə, qan təhcizatı yüksək olduğu üçün hiperdens görünürlər. Bəd xassəli və xoş xassəli şişləri fərqləndirmək üçün törəmənin homogenliyi və konturlarının düzgünlüyünə baxılır. Bəd xassəli şişlərdə nekroz çox rast gəldiyi üçün heterogen- hipo və hiperdens sahələr görünür. Hemangiomaların dəqiq diaqnozu dinamik BT ilə qoyulur. Kontrast verildikdən 1-2 və 8-10 dəq sonra tomoqrafiya çəkilr. İlk tomoqrammalarda törəmənin periferiyası kontrastlaşır, mərkəzində isə, kontrast görünmür. 810 dəq sonra çəkilən tomoqrammalarda isə, mərkəzində kontrast görünür, periferiyada isə, kəskin azalır və ya heç görünmür. Bu kavernalarda qan axınının azalması ilə əlaqədardır.

Gecikmiş BT müayinəsi kontrast vurulduqdan 2-4 saat sonra aparılır. Bunun üçün şiş toxumasında uzun müddət tutula bilən (lipoidol, iodin) kontrast maddələr istifadə edilir. Bu üsul şişlərin müəyyən olunması üçün istifadə edilir.

BT-nin üstün cəhətləri:

* Orqanların forma, daxili quruluşu və diğər orqanlara münasibətini dəqiq bir şəkildə göstərir ki, bunu cərrah da qiymətləndirə bilir, beləliklə, subyektivizm aradan qalxır.

* Patoloji törəmənin yeri və ölçüləri dəqiq görünür.

* Qaraciyərdə 1 sm-dən böyük törəmələri 60-70\% həssaslıqla göstərir.

* Hemangiomaların, kistlərin, hematomaların, qaraciyər zədələnmələrinin, absesin diaqnozunu dəqiq təyin etməyə imkan verir.

* Qaraciyərin bir çox parenxima xəstəliyini, xüsusən yağ distrofiyasını tə’yin etməyə imkan verir.

* Qaraciyər və törəmələrin həcmlərini 5-10\% xəta ilə ölçməyə imkan verir.

* BT nəzarəti altında bir çox diaqnostik və müalicəvi müdaxilələr edilə bilir.

Bunlarla yanaşı BT-nin bir çox çatışmayan cəhətləri də vardır:

* Rentgen şüalanması olduğu üçün bu üsul bə'zi hallarda (hamiləlik) istifadə edilə bilmir 
* Bahalı olması və daşına bilməməsi

* Qaraciyərin 1 sm-dən kiçik və səthdə yerləşən törəmələrində həssaslığının çox az (10\%) olması. (törəmələrini göstərməkdə ümumi həssaslığ $50-60 \%$ )

* Şişləri bir-birindən ayırmada spesifikliyinin yüksək olmaması $(50-70 \%)$

* Damar mənfəzinə invaziyonları dəqiq göstərə bilməməsi

\section{NÜVӘ-MAQNIT REZONANS TOMOQRAFIYA}

Nüvə-maqnit rezonans tomoqrafiya, və ya maqnit rezonans görüntüləmə (MRG) üsulu hidrogen atomu nüvəsinin spinini dəyişdirərkən törətdiyi şüalanma prinsipinə əsaslanmışdır. Mə’lumdur ki, müsbət yüklü nüvə öz oxu ətrafında firlanır və maqnit sahəsi əmələ gətirir (spin). Güclü maqnit sahəsinin tə’siri ilə nüvənin maqnit vektoru dəyişdirilir və nüvə yeni energetik səviyyəyə gətirilir. Xarici tə'sir aradan qaldırıldıqdan sonra nüvə öz əvvəlki vəziyyətinə qayıtdıqda kvant şüalandırır, şüalanan bu kvantlar qəbuleicilərlə qeyd edilir. BT-də olduğu kimi, toxumanın vahid həcmindən gələn şüalanma bilgisayarla hesablanır və görüntüyə çevrilir. Beləliklə, toxumalar tərkibindəki hidrogen atomunun miqdarından asılı olaraq müxtəlif dərəcədə şüalanma törədir ki, bu da onların fərqli görünməsini tə'min edir. Hidrogenlə zəngin toxumalar hiperintens, hidrogeni az olan toxumalar hipointens görünür.

MRG ilə vücudun istənilən istiqamətdə kəsiklərini almaq olar. BTdən fərqli olaraq, MRG-nin ən böyük üstünlüyü yumşaq toxumaların daha aydın görünməsinə imkan verməsidir. Qaraciyərin müayinəsində MRG BTyə yaxın nəticələr göstərir. MRG-nin də kontrastlı və kontrastsız üsulları vardır. Son illər rəngli və hüceyrəspesifik kontrastlı MRG üsulları inkişaf etdirilir.

MRT-nin üstün cəhətləri:

* Şüalanma ehtimalı yoxdur.

* $\quad 1$ sm-dən kiçik törəmələrin aşkar edilməsində həssaslığı yüksəkdir 
* Yumşaq toxumaları daha aydın göstərdiyi üçün törəmələrin daxili quruluşunu daha aydın göstərir.

* $\quad$ Bə’zi şişlərin differensasiyasında BT-dən daha qiymətlidir.

* Kontrast istifadə edilmədən (1şıldatma metodu) öd axacaqlarını göstərə bilir.

* Son illər hüceyrəspesifik kontrastların tətbiqi ilə perspektiv bir MRG üsulu inkişaf etdirilməkdədir ki, bu da toxumanın hüceyrə tərkibini müəyyən etməyə imkan verir.

MRG-nin çatışmayan cəhətləri:

* Hərəkət görüntüyü poza bilir, ona görə də hərəkətli orqanların görüntüsü dəqiq olmur.

* Bədəndə metal (klip, elektrodlar), elektrostimulyator olan hallarda istifadə edilməsi əks göstərişdir.

* Bahalıdır, daşınmır.

\section{QARACIYӘR XəSTӘLIKLӘRININ GÖRÜNTÜLӘMӘ OLAMӘTLӘRİ VӘ SINDROMLARI}

Yuxarıda qeyd edildiyi kimi, görüntüləmə üsulları qaraciyəri anatomik-morfoloji cəhətdən göstərən vasitələrdir. Xəstəliklərin qaraciyərdə törətdiyi diffuz və ya yerli dəyişiklikləri aşkar etmək görüntüləmə üsullarının ən əsas vəzifəsidir. Patoloji proseslər qaraciyərin ölçüsündo, toxuma tərkibindo, qan dövranında, öd axınında dəyişiklik törədə bilirlər. $\mathrm{Bu}$ ələmətlərin müəyyən edilməsi xəstəliyin tə’yin olunmasında əhəmiyyətlidir. Ona görə də qaraciyər xəstəliklərinin görüntüləmə üsulları ilə tə'yin olunan əlamətlərindən ümumi şəkildə bəhs etmək məqsədəuyğundur.

Qaraciyərin ölçüsü. Oksər görüntüləmə üsulları qaraciyərin ölçüsü haqqinda mə'lumat verir. Lakin, daha dəqiq mə'lumat USM və tomoqrafiya üsulları vasitəsi ilə alınır. Qaraciyərin ölçüsünü qiymətləndirmək üçün həcmi və ya orta körpücük xətti üzrə ən böyük ön-arxa (kaudo-kranial) eni 
hesablana bilər. Qaraciyərin həcmi tomoqrafiya ilə, eni isə, tomoqrafiya və ya USM ilə müəyyən edilir.

Həcmi hesablamaq üçün qaraciyərin hər kəsiyinin sahəsi hesablanır (S) və kəsiyin sahəsi onun qalınlığına (h) vurularaq hər kəsiyin həcmi tapılır. Kəsiklərin həcmlərinin cəmi qaraciyərin ümumi (V) həcmini verir:

$$
V=S_{1} h_{1}+S_{2} h_{2}+S_{3} h_{3}+\ldots+S_{n} h_{n}
$$

Normal qaraciyərin eni $12-14 \mathrm{sm}$, həcmi isə, 1100-1400 $\mathrm{sm}^{3}$ təşkil edir.

Qaraciyər ölçüsünün böyüməsi- hepatomeqali (eni > 14 sm, həcmi $>1400 \mathrm{sm}^{3}$ ) qaraciyərin əksər xəstəliklərində müşahidə edilir. Parenxima xəstəlikləri (sirrozun erkən dövrü, hepatitlər, hepatozlar), venoz axının pozulması (Baddi Chiari sindromu, ürək yetməzliyi), öd axınının pozulması (xolangit, xolestaz) və törəmələr (kist, şiş) hepatomeqaliyaya səbəb olurlar.

Qaraciyərdə qan dövranının azalması (qap1 venası trombozu, arterial tromboz), atrofik-distrofik proseslər (sirroz), yayğın nekroz (fulminant hepatit) qaraciyərin ölçülərinin azalmasına səbəb olur.

Qaraciyərin toxuma torkibi. Qaraciyərin toxuma tərkibini qiymətləndirmək üçün istifadə olunan müasir üsullar sıxlıq dərəcəsi (şüaları udma, əks etdirmə, şüalandırma) və ya kontrast tutma prinsiplərinə əsaslanır. USM-də ekogenlik, BT-də densite, MRG-də isə, intensivlik terminləri ilə ifadə olunan sıxlıq dəracəsi toxumaların bir-birindən ayrılmasını tə'min edən ən mühüm göstəricidir. Hazırkı görüntüləmə üsulları patoloji dəyişiklik bölgəsindəki hüceyrə tipini ayırd etməkdə tam yetərli deyildir. Yaxın gələcəkdə spesifik kontrastlı MRG ilə bunun da mümkün olacağı şübhə yaratmır. Hazırkı kontrastların əksəriyyəti daha çox qan damarlarını göstərməkdə, az qismi isə, (iodinol) xərçəng hüceyrələrində tutulur.

Normal qaraciyər hepatosit kütləsindən, damar, axacaq və bunları müşayət edən birləşdirici toxumadan ibarətdir. Parenxima normal halda izoekoik, izodens, isointensiv görüntü verir və bu görüntü normal dalaq və böyrəyin sıxlığına yaxındır. Qaraciyər damarları və axacaqları hipodens strukturlar kimi görünür.

Parenxima elementlərinin nisbət dəyişməsi görüntünün müxtəlif olmasına səbəb olur. Slxlı̆̆ yükssək olan birləşdirici toxuma elementlərinin üstünlük təşkil etdiyi xəstəliklərdə (sirroz, fibroz, çapıq toxuma), 
kalsifikasyonlarda hiperdens və ya hiperekoik görüntü verirlər. Parenximanın (şişlər) və ya mayeninin (kist, ödem, nekroz, hematom, hemangiom) üstünlük təşkil etdiyi hallarda isə, hipoekoik və ya hipodens görüntü ortaya çııır.

Toxumanın paylanması. Toxumanın tərkibindəki müxtəlif sıxlıqlı elementlərin paylanma dərəcəsindən asılı olaraq görüntüləmə üsulları iki tip görüntü verə bilir. Eynicinsli toxumalar homogen, müxtəlif cinsli toxumalardan ibarət orqan və törəmələr isə, heterogen görünür.

Normaal qaraciyərdə hepatosit və kapillyarların USM cə tomoqrafik görüntüsü homogen şəkildə olur. Kontrast verildikdə də normal parenxima homoğen şəkildə görünür, böyük damarlar isə, fərqli görüntü verir.

Eyni cinsli toxumalardan təşkil olunmuş şişlər, kistlər, nekroz, kiçik hemangiomlar homogen görüntü verirlər. Heterogen görüntü isə, adətən sıxlığ göstərir. Yağlı qaraciyər, çapıq toxuma və nekroz bölgələri olan şişlər, nodular sirroz, damar toxuması və kavernoz ciblərdən ibarət olan böyük hemangiomalar, q1z qovucuqları olan exinokokk, qan laxtası və maye qandan ibarət hematomlar və s. heterogen görünürlər.

Toxumada qan dövranını göstərmək üçün angioqrafiya, kontrastlı tomoqrafiyalar,doppler USM kimi üsullardan istifadə edilir. Xəstəlik nəticəsində qan təhcizatı normal qaraciyərə nəzərən deyişməyə bilər (normovaskular), arta (hipervaskular), azala (hipovaskular) və heç olmaya (avaskular) bilər.

Angioqrafik və kontrastlı üsullarda hipervaskular bölgələrdə kontrast artdığı üçün hiperdens görüntü, hipovaskular bölgələrdə isə, hipodens görüntü ortaya çıxır. Kontrastlı müayinələrdəki hipo- və hiperdens görüntülərlə kontrastsız müayinələrdəkini qarışdırmamaq lazımdır. Xatırlatmaq lazımdır ki, kontrastsız müayinələr toxumanın sıxlıq xüsusiyyətini, kontrastlı müayinələr isə, qan təhcizatını göstərir. Tomoqrammalarda bunları qarışdırmamaq üçün böyük damarlarda kontrastın olub olmadığına diqqət etmək lazımdır.

Normal qaraciyərdə qan təhcizatı bərabər paylandığı üçün normovaskular və homogen görünür. Qan təhcizatının araşdırılması canlı 
toxumaları (solid) qan təhcizatı olmayan (kist, nekroz, daş, kalsifikasyonlar) törəmələrdən ayırmaq üçün əhəmiyyətlidir. Kistlər daxilində damar olmadığı üçün angioqrafiyada avaskular görünür, kontrastlı tomoqrafiyada kontrastlaşmır,doppler USM-də isə, axın qeyd edilmir. Çapık toxuma, ödemli toxumalar hipovaskular (kontrastla hipodens) görünürlər. Şiş toxumaları damarla zəngin olduqları üçün hipervaskular görünürlər.

Böyük damarları qiymətləndirmək üçün ən geniş istifadə edilən angioqrafiya,doppler USM və hazırda inkişaf etməkdə olan MRGangioqrafiya üsullarıdır. USM və BT-də damarlar böyük damarlar görünür, lakin onların daha dəqiq müayinəsi üçün doppler və angioqrafiya lazım gəlir. Damarda deformasiya, daralma, tıxanma və qan axınının azalması patoloji prosesin olduğınu göstərən ən vacib əlamətlərdir. Adətən xoş xassəli şişlər və kistlər damarları itələyərək deformasiyaya uğradar, bəd xassəli şişlər isə, damarlara sirayət edərək mənfəzini daraldar. Bəd xassəli şişlərin magistral damarlara yaxınlığı və sirayət etməsinin öyrənilməsi onların dövrünün müəyyən olunmasında və rezeksiyanın həcminin müəyyən edilməsində əhəmiyyətlidir.

Öd axacaqlarını göstərilməsi üçün USM, xolangioqrafiya, radioizotop müayinə, və kontrastsız işıltılı MRG istifadə edilməkdədir. Genişlənmə, daralma, tıxanma və ödün axacaqlardan kənara çıxması öd yolları patologiyasının ən çox rast gələn əlamətidir. Genişlənmə USM ilə görünür. Öd yollarındakı dəyişiklikləri dəqiq görmək üçün xolangioqrafiya ən yararlı üsuldur. Son illər kontrastsız və noninvaziv üsul olan işıntılı MRG öd yollarının görünməsi üsulu inkişaf etməkdədir.

SINDROMLAR. Qaraciyər xəstəliklərinin diaqnostikasında sindromoloji yanaşma əhəmiyyətli yer tutur. Olamətlər $\rightarrow$ sindrom $\rightarrow$ xəstəlik alqoritminin düzgün yerinə yetirilməsi, xəstəliyin diaqnozunun müəyyən edilməsini asanlaşdırır. Müxtəlif görüntüləmə üsullarının göstərdiyi əlamətlər bir çox simptomokompleksi - morfoloji sindromları ortaya çıxarır.

Qaraciyər xəstəliklərinin törətdiyi morfoloji dəyişiklik və görüntüləmə üsulları ilə də, görünən əlamət qaraciyər ölçüsünün dəyişməsidir. Ölçü dəyişikliyi yayğın （diffuz) və ya yerli (lokal) ola bilər. 
Diffuz dəyişikliklər ən çox böyümə şəklində - hepatomeqaliya əlaməti ilə ortaya çıxır. Qaraciyər ölçüsünün azalmasına az rast gəlir. Yerli ölçü dəyişikliyi qaraciyər törəmələri və yerli zədələnmələri tərəfindən törədilir.

Yaygın hepatomeqaliya əksər hallarda parenximanın, qan axınının, öd yollarının diffuz şəkildə pozulmasının əlaməti kimi ortaya çıxır. Qaraciyərin bir çox xəstəliklərində hepatomeqaliya ilə yanaşı toxuma tərkibindəki, qan təhcizatındakı dəyişikliklərin görüntüləri bir-birinə çox yaxın olur. Hətta eyni xəstəlik müxtəlif dövrlərdə ayrı-ayrı dəyişiklik törədir. Ona görə də diffuz xəstəliklər üçün yüksək diaqnostik əhəmiyyətli görüntü sindromları müəyyən etmək çətindir.

Bunun əksinə, yerli xəstəlik və zədələnmələr bir-birindən fərqli görüntüləmə sindromları verirlər. Tam doğru olmasa da yerli xəstəliklər və zədələnmələr ümumi ad altında- törəmə ifadəsi ilə veriləcəkdir.

Görüntüləmə üsulları ilə yerli dəyişikliklər dörd əsas sindrom şəklində görünürlər:

1. Kistik törəmələr (suluqlar)

2. Toxumalı (solid) törəmələr

3. Kalsifikasionlar

4. Qarışıq törəmələr

Kistik törəməlar mayenin toplanması nəticəsində ortaya ç1xan patologiyalardır. Dəqiq sərhədli olmasl, maye olduğu üçün hipo-, anekoik və ya hipodens görünməsi, qan təhcizatının olmaması (avaskular) əsas görüntü alamatlaridir. USM kistlərin müəyyən edilməsində yüksək həssaslıq və spesifiklik göstərir. Kistlərin təbiətini ( parazitar, neoplastik, anadangəlmə və s.) müəyyən etmək üçün daxili quruluşuna baxmaq və xüsusi əlamətlərini araşdırmaq lazımdır. Məsələn, xitin qatının, q1z qovucuqlarının görünməsi exinokokk kistləri üçün, incə divar anadangəlmə kistlər üçün, kist boşluğunda papillamatoz çıxıntı şəklində toxumaların görünməsi neoplastik kistlər üçün xarakterikdir.

Toxumalı (solid) törəməlar yerli hiperplaziya (şiş, düyünlər), zədələnmə (atrofiya, nekroz) nəticəsində əmələ gələn, yaşayan və ya ölü toxumalardan ibarət olan patologiyalardır. Mayedən yüksək sixlıq alamətlari 
(USM-do hipo-, izo-, hiperekoik, BT-do iso, hipo-, izo-, hiperdens) vo müəyyən daracada qan təhcizatının olması (hipo-, izo-, hipervaskular) toxumalı töramalar üçün xarakterik görüntü simptomlarıdır.

Kalsifikasionlar toxumaya hədsiz miqdarda kalsium duzlarının çökməsi nəticəsində əmələ gələn törəmələrdir. Kalsifikasionlar adətən distrofik mənşəli olur, yə'ni yerli toxuma nekrozu nahiyəsinə kalsiumun çökməsi nəticəsində əmələ gəlir. Nadir hallarda metastatik, yə’ni hiperkalemiya nəticəsində baș verir. Yüksək sıxlıq (hiperdekoik, hiperdens) və avaskular görüntü əlamətləri kalsifikasionlar üçün xarakterikdir. Daşlar, infeksiyon düyünlərində (vərəm, brüsellyoz və s), hematomalarda, şişlərin nekrotik bölgələrində, exinokokk kisti divarında kalsifikasionlar bu görüntüləmə sindromu verirlər.

Qarışıq törəmələr həm maye, həm toxuma, bə’zən də kalsifikasiondan ibarət törəmələrdir. Kistik, toxumalı və kalsifikasion əlamətlərin birlikdə ortaya çıxması nəticəsində adətən heterogen görünürlər. Nekrotik abseslər, böyük hemangiomalar, hematomlar və bə'zi hallarda isə, sistoadenomalar qarışıq şəkildə görünürlər.

Eyni görüntü sindromu verən xəstəlikləri bir birindən ayırmaq üçün ölçü, sıxlıq, qan təhcizatı, daxili quruluşu, ilə yanaşı böyük damarlara münasibəti, sərhədləri, öd axacaqlarına münasibəti araşdırılır. Bunlar yetərsiz olduqda spesifik laborator və histopatoloji müayinələr lazım gəlir. 


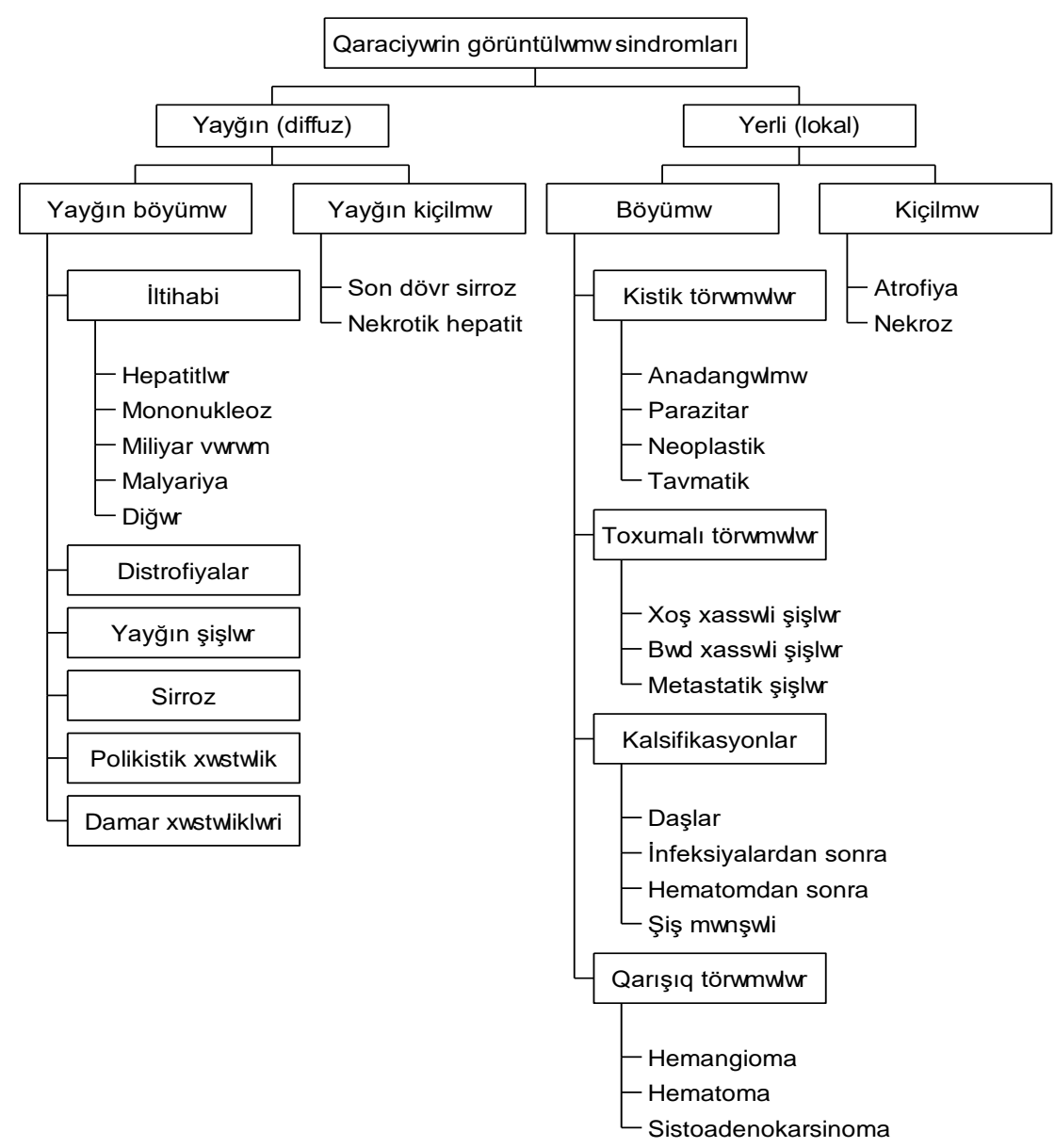

LABORATOR MÜAYINOLӘR

Qaraciyər funksional cəhətdən zəngin olduğu kimi, müayinə üsulları da çox çeşidlidir. Laborator müayinə üsulları qaraciyərin funksional vəziyyətini, hepatositlərdə zədələnməni və xəstəliklərin spesifik 
göstəricilərini müəyyən etmək üçün istifadə edilir. Klinik praktikada istifadə edilən çoxsaylı laborator göstəriciləri aşağıdakı gruplar halında toplamaq olar:

1. Hepatositar zadəlanma göstəriciləri

2. Sintetik funksiyasının göstəriciləri

3. Detoksikasiya funksiyasının göstəriciləri

4. Metabolik-energetik funksiyasının göstəriciləri

5. Sekretor funksiyasının göstəriciləri

6. Virus va şiş markerləri

\section{HEPATOSITLӘRİN ZəDӘLӘNMӘ GÖSTӘRİCILӘRİ}

Hepatositlərdə baş verən zədələnmə nəticəsində hüceyrə içərisindəki maddələr qana keçirlər. Bu maddələr zədələnmə indikatoru rolu oynayırlar. Zədələnmə göstəriciləri kimi, klinikada ən çox alanin aminotransferaza (ALT), aspartat aminotransferaza (AST) və qammaqlütamil transferazanın (QQT) qandakı səviyyəsindən isitafadə olunur. $A L T$ va AST hepatositlorin sitozolunda,QQT isə, membranına birlaşmişş̧ૂkildo yerlaşir. Hepatositlorda baş veran zadalonma naticasindo enzimlar sitozoldan vo membrandan çıxaraq qana keçirlar. Bu iso, onların qandakı miqdarlarinın artmasina sabəb olur.

$\boldsymbol{A L T}$ hepatositlərin sitozolunda yerləşir və alanin ilə qlütamat aminturşuları arasında amin qrupu mübadiləsini tə’min edir. Bu enzim ən çox qaraciyərdə olur. Lakin, ürək və skelet əzələlərində də tapılır.

Normal halda ALT-ni qandakı səviyyəsi 20-40TV/L-dir. ALT səviyyəsinin 2 dəvədən çox artması hepatosit zədələnməsini göstərir. ALT səviyyəsində artma klinik əlamətlərdən daha erkən müşahidə olunur. Qaraciyərin iltihabi və diğər mənşəli zədələnmələrində ALT səviyyəsi normadan 20-50 dəfə, hətta 100 dəfə çox arta bilər. Skelet və ürək əzələlərində zədələnmə olduqda da artma müşahidə edilir. Lakin, AST-dən fərqli olaraq ALT qaraciyər zədələnməsi üçün daha spesifikdir. Qanda 
enzimin yarım parçalanma ömrü 48 saat təşkil edir və zədələnmə aradan qalxdıqdan 4-5 gün sonra normal səviyyəyə qayıdır.

$\boldsymbol{A S T}$ aspartat ilə qlütamat aminturşuları arasında amin qrupu mübadiləsini tə'min edir. Bu enzim qaraciyərdə, ürəkdə, skelet əzələlərində, böyrəkdə və eritrositlərdə tapılır. Qanda enzimin yarım parçalanma ömrü 48 saatdir.

Normal halda AST-ni qandak1 səviyyəsi 20-40TV/L-dir və ALT/AST nisbəti 1-dən kiçikdir. AST səviyyəsinin artması ən çox qaraciyər və ürək xəstəliklərində müşahidə olunur. Qanda enzimin yarım parçalanma ömrü 48 saat olduğu üçün enzimim zədələnmə aradan qalxdıqdan 4-5 gün sonra normal səviyyəyə çata bilir.

Qaraciyər zədələnmələrində AST adətən ALT ilə birlikdə artır. ALT-nin AST-yə nəzərən daha çox artması vəALT/AST nisbətinin 1-dən böyük olması hepatositlərdə nekrobiozu göstərir. Hər iki enzim artarkən, bu nisbətin 1 dən kiçik olması qaraciyərdən kənar səbəblərlə əlaqədar və ya qaraciyərdə dərin nekroz olduqda müşahidə edilir. Bunun səbəbi AST-nin yerləşməsi ilə əlaqədardır. ALT-dən fərqli olaraq AST hepatositlərin həm sitozolunda, həm də mitoxondrilərində yerləşir. Nekrobioz hallarında yalnız sitozoldakı enzimlər xaricə çıxa bilir və ALT-nin sitozoldakı miqdarı ASTdən çox olduğu üçün ALT/AST nisbəti 1-dən böyük olur. Dərin nekroz mitoxondrinin pozulması ilə müşayət olunur ki, bu da sitozoldakı AST-nin də qana çıxmasına səbəb olur. Nəticədə qandakı AST səviyyəsi ALT səviyyəsindən yüksək olur. Miokardda AST daha çox olduğu üçün, zədələnmələrdə ALT/AST səviyyəsi 1-dən kiçik olur.

$Q Q T$ hepatositlərin və öd epitelinin membranlarında yerləşən enzim olub, zülallar və kiçik pepdidlər arasında qlütamilin mübadiləsini həyata keçirir. ALT və AST-dən fərqli olaraq qaraciyər üçün daha spesifikdir və yarım parçalanma ömrü daha qisa (24 saat) olduğu üçün, daha həssasdır. Qaraciyərdə zdələnmə aradan qalxdığı hallarda ALT və AST 4-5 gün sonra normal səviyyələrə qayıtdığı halda QQT 1-2 gün içərisində normallaşır.

Normal halda QQT-nin qandak1 səviyyəsi 50TV/L-dən kiçikdir. Enzimin qandakı səviyyəsinin artması başlıca olaraq iki patoloji prosesdəhepatosit zadəlanməsindo vo xolestazda müşahidə edilir. Hepatositar 
Qaraciyərin müayinə üsullart

zədələnmədə QQT artışı ALT və AST ilə birlikdə müşahidə edilir. Xolestazda isə, QQT ilə yanaşı qələvi fosfataza və 5-nukleotidaza da artır.

Qaraciyər zədələnməsində laktat-, sorbitol-, qlütamat dehidrogenaza və s. fermenlar də artır. Lakin bunların spesifikliyi az və ya bahalı olduğu üçün klinik praktikada az istifadə edilir.

Beloliklo, hepatositlordo zodolonməni qiymotlondirmək üçün hüceyro sitozolundan (ALT, AST) vo membraninan (QQT) ayrilıb qana keçən enzimlarin saviyyalori ölçülür.

\section{SINTETIK FUNKSIYYALAR}

Sintetik funksiyalar dedikdə, qaraciyərdə orqanizmə yararlı maddələrin sintez olunması nəzərdə tutulur. Qaraciyərdə bir çox zülal, yağ, karbohidrat və s. tipli maddələr sintez olunur. Qaraciyərin sintetik funksiyasını qiymətləndirmək üçün klinikada geniş istifadə olunan albumin və protrombindən başqa, elmi tədqiqatlarda bir çox diğər faktorlar da araşdırılır.

Albumin qaraciyərdə sintez olunan vo plazmada onkotik təzyiqi tə'min edən, transport və anabolik funksiyaları yerinə yetirən zülaldır. İnsan orqanizmində orta hesabla gündə $20 \mathrm{~g}$ albumin sintez edilir və bir o qədər də itirilir. Albuminin yarım parcalanma dövrü 18-20 gündür. Albuminin qanda azalması ya çoxlu miqdarda itirilməsi, ya da qaraciyərdə az sintez edilməsi ilə əlaqədardır. Xüsusən, qaraciyərin xroniki xəstəliklərində və böyük həcmli rezeksiyalarından sonra albuminin plazmada miqdarı azalır. Normada albuminin plazmada miqdarı 35-40 g/l-dir.

Prealbumin qaraciyərdə sintez olunan zülaldır və funksiyası albuminə yaxındır. Yarım parçalanma dövrü 1,9 gün olduğu üçün qaraciyərin sintetik funksiyasını qiymətləndirmədə albumindən daha həssasdır. Prealbumin sınağınadan orqanizmdə zülal sintezini, anabolik və katabolik vəziyyətləri və orqanizmin qidalanma vəziyyətini qiymətləndirmək üçün istifadə edilir. Prealbuminin plazmada miqdarı 100$400 \mathrm{mg} / \mathrm{l}-$ dir.

Alfa $_{1}$-antitripsin qaraciyərdə sinez olunan glikoprotein olub, orqanizmdə ən vacib proteinaza inhibitorudur. $\mathrm{Bu}$ faktorun qaraciyərdə 
anadangəlmə sintezi azlığında uşaqlarda qaraciyər və ağciyər fibrozu baş verir ki, bu xəstəliyin müalicəsi qaraciyər köçürülməsi ilə mümkün olur. Alfa ${ }_{1}$-antitripsinin qanda tə’yini onun defisiti səbəbi ilə yerinə yetirilən qaraciyər köçürülməsində daha çox istifadə edilir.

Antihemofilik faktor (VIII faktor), toxuma plazminogen aktivatoru və urokinazadan başqa laxtalanma, fibrinoliz faktorlarının vo bunların inhibitorlarının əksəriyyəti qaraciyərdə sintez $\operatorname{olunur}^{l}(C ə d v a l$ 2).

Qaraciyərdə sintetik prosesi qiymətləndirmək üçün daha çox $P Z$ sınă̆ından istifadə edilir. A ğır, kəskin və xroniki qaraciyər xəstəliklərində, xolestazlarda, böyük həcmli rezeksiyalarda və qaraciyər köçurulməsindən sonrakı ilk günlərdə hepatosellular yetməzlik və ya $\mathrm{K}$ vitamininin defisiti ilə əlaqədar, laxtlalnma faktorlarının sintezi azalır və bu da PZ artması ilə tə'yin olunur.

Codval 2.1. Plazma laxtalanma faktorlart vo qaraciyordo sintez olunan oks-laxtalanma faktorları.

\begin{tabular}{|c|c|c|}
\hline Sayt & Adl & Sintez olunduğu orqan \\
\hline $\mathrm{I}$ & Fibrinogen & Qaraciyər, Kupffer hüceyrələri \\
\hline II & Protrombin & Qaraciyər* \\
\hline III & Toxuma faktoru (tromboplastini) & Qaraciyər vo trombosit \\
\hline IV & $\mathrm{Ca}^{++}$ & \\
\hline V & Proakselerin & Qaraciyər \\
\hline VI & Adlandırılmamış & $\begin{array}{l}\text { Faktor } \mathrm{V} \text { aktivləşmiş formas } 1 \\
\text { olaraq qəbul edilir }\end{array}$ \\
\hline VII & Prokonvertin & Qaraciyər* \\
\hline VIII & Antihemofilik faktor & Endotel \\
\hline IX & $\begin{array}{l}\text { Kristmas } \\
\text { tromboplastini) }\end{array} \quad$ faktoru & Qaraciyər* \\
\hline $\mathrm{X}$ & $\begin{array}{l}\text { Stuart-Prover faktoru (trombokinaza- } \\
\text { protrombini trombinə çevirən) }\end{array}$ & Qaraciyər* \\
\hline XI & Plazma tromboplastin sələfi & Qaraciyər \\
\hline XII & $\begin{array}{l}\text { Hageman faktoru (təmas-kontakt } \\
\text { faktoru) }\end{array}$ & Qaraciyər \\
\hline XIII & Fibrini stabilloşdirən faktor & Qaraciyər \\
\hline & Antitrombin III & Qaraciyər \\
\hline
\end{tabular}
${ }^{1}$ Antihemofilik faktor (VIII faktor) vo toxuma plazminogen aktivatoru endotelda,
urokinaza isə böyroklordə sintez olunurlar 
Qaraciyərin müayino üsullart

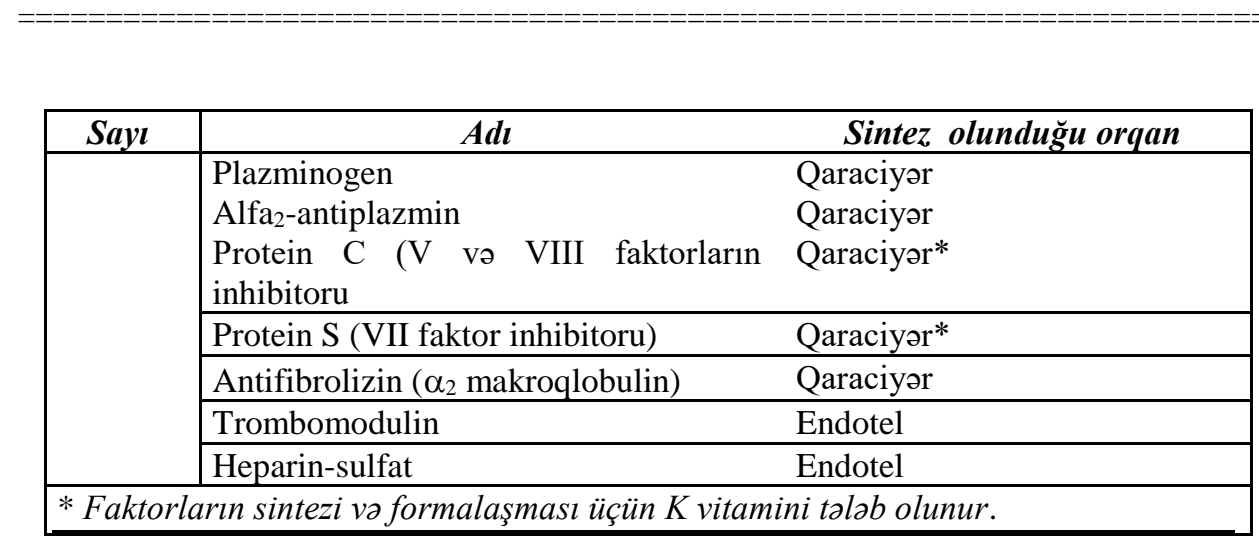

Bundan başqa, PZ sınağından K vitamini antoqonistləri (kumarin) ilə müalicədə nəzarət üçün də istifadə edilir. Normada PZ 10-13 saniyə arasında dəyişir və bu zamanın 3 saniyədən və ya 1,3 dəfədən çox uzanması qanaxma təhlükəsini xəbər verir. PZ saniyə ilə ölçülməsindən başqa, \% və beynəlxalq nisbətlə də ölçülə bilir.

$\boldsymbol{A H T Z}$ sınă̆ entoteldən sintez olunan antihemofilik faktorlar və əks-laxtalanma faktorlarına da həssasdır. Ona görə də, bu sinaqdan endotelin yaygın zədələnməsi (qaraciyər köçürülməsi) və ya hipofunksiyası (hemofiliya xəstəliyi, vaskulitlər, sepsis və s.) ilə müşahidə olunan hallarda, əkslaxtalanma faktorların yüksək aktivliyi hallarında (heparinlə, antitrombinlə müalicədə) geniş istifadə olunur.

Fibrinogen qaraciyərdə Kupffer hüceyrələrində sintez olunmasına baxmayaraq, onun qandakı miqdarının tə'yini qaraciyərin funksional vəziyyəti haqqında təkbaşına dəqiq mə'lumat vermir. Çünki onun miqdarı laxtalanma sisteminin aktivliyindən də asılıdır və xüsusən yayğın damardaxili laxtalanma sindromunda (YDLS) çox azalır. Ona görə də fibrinogen miqdarını qiymətləndirərkən digər sınaqların nəticələrinə də baxmaq lazımdır. Normada plazmada fibrinogenin miqdarı 2-4 g/L təşkil edir.

Xolinesteraza hepatositlərdə sintez olunan və asetilxolini parçalyan fermentdir. Qaraciyərin sintetik funksiyasını qiymətləndirmək üçün nisbətən həssas sınaqlardan sayılır və köçurulən qaraciyərin funksional 
vəziyyətini qiymətləndirmək üçün istifadə olunur. Normada plazmada xolinesterazanın migdarı 4,9-11,9 kV/L təşkil edir.

Qaraciyərdə sintez olunan lesitin-xolesterin asiltransferaza, lipoproteinlər, xolesterin, seruloplazmin, transferrin və s. kimi diğər maddələrin sintetik funksiyasını qiymətləndirmədəki rolu çox yüksək deyildir.

\section{QARACIYORIN ZəRəRSIZLOŞDIRMə FUNKSIYYALARI}

Zərərsizləşdirmə və ya detoksikasiya adı altında orqanizm üçün zərərli və ya yararsız olan maddələrin zərərsizləşdirilməsi, orqanizmdən atılması və ya orqanizmdən atıla bilən şəkilə salınması prosesləri nəzərdə tutulur. Orqanizmdə mövcud olan 3 əsas detoksikasıya sistemlərinin (immun, metobolik, ifrazat) komponentləri qaraciyərdə var. Qaraciyərdə olan retikuloendootelial hüceyrələr- Kupffer hüceyrələri orqanizmin immun müdafiəsində, öd sekresyası isə ifrazat proseslərində mühüm rol oynayır. Hepatositlər endogen və ekzogen toksiki maddələri, dərmanları, bioloji aktiv maddələri, hormonları, metobolizim tullantılarını parçalanma, oksidlləşmə, birləşmə və s. proseslərə mə'ruz qoyaraq, zərərsiz və orqanizmdən atılacak şəkilə salır.

Qaraciyərin zərərsizləşdirmə funksiyasını qiymətləndirmək üçün istifadə olunan sınaqların əsasında 2 prinsip durur:

1. Təmizləmə sınaqları. Bu sınaqlarda maddənin qandakı miqdarına görə, onun qaraciyərdə zərərsizləşdirmə intensivliyi barədə məlümat alınır. Ammonyak, birləşməmiş bilirubin, bromsulfalein, indosianin yaş1l, koffein, öd turşuları və s. sınaqları bu qrupa aid edilir.

2. Biotransformasiya sinaqları. Bu sinaqlarda verilən maddənin özü yox, onun qaraciyərdəki metabolizma məhsullarının qanda ölçülməsi yolu ilə zərərsizləşdirmə funksiyası qiymətləndirilir. Birləşmiş bilirubin, lidokain, müxtəlif dərmanlar və hormonlarla aparılan sınaqlar buna aiddir.

Bilirubinin qandakı miqdarını tə'yin etməklə, qaraciyərin bir çox zərərsizləşdirmə funksiyaları haqqında mə'lumat almaq olur. Sərbəst 
bilirubin hemolizin və hepatositlərin maddələri tutma qabiliyyətinin, birləşmiş bilirubin isə hepatositlərin biotransformasiya, sekresiya qabiliyyətinin və öd yolarındakı ekskresiya proseslərinin göstərcisidir. Ona görə də, bilirubinlərin qandakı miqdarının tə’yini ilə qaraciyərin funksional vəziyyəti haqqinda ilkin və bir çox hallarda dəqiq mə'lumat almaq olur. Bilirubin entero-hepatik dövranda iştirak etdiyi üçün nəticələrin qiymətləndirilməsində yanılmalar ola bilir. Normada total bilirubin 3,4-17,1 $\mu \mathrm{mol} / \mathrm{L}(0,2-1,0 \mathrm{mg} / \mathrm{dL})$, birləşmiş bilirubin $0-3,4 \mu \mathrm{mol} / \mathrm{L}(0-0,2 \mathrm{mg} / \mathrm{dL})$ arasinda olur.

Ammonyak orqanizmdən kənar edilməsi lazım gələn başlıca endogen metabolitdir. Ammonyak başlıca olaraq, 2 mənbədən gəlir, 2 yolla qanla daşınır və 2 yolla zərəsizləsdirilir. Ammonyakın başlıca mənbələri toxumalarda gedən azot mübadiləsi (amiturşu, purinlər, pirimidinlər) və bağırsaqda glütaminin və sidik cövhərinin bakteriyalar tərəfindən parçalanmasıdır. Ammonyak qanda birləşmiş̧ şəkildə (glütaminin, alanin və aspartat aminturşularının tərkibində) və sərbəst şəkildə- ammonium ionu şəklində $\left(\mathrm{NH}_{4}^{+}\right)$daşınır. Ammonyakın yavaş sür'ətli, lakin, əsas zərərsizləşdirmə yolu qaraciyərdəki sidik cövhəri dövranıdır. İkinci yolu olan böyrəklərdəki glütaminin parçalanma yolu isə, nisbətən zəif, lakin sür'ətli yoldur. Ammonyakın qanda artması iki başlıca yolla baş verə bilir: birincisi, qaraciyərin mütləq yetməzliyi nəticəsində sidik cövhəri dövranının imkanlarının azalması; ikincisi, porto-kaval şuntların olması nəticəsində bağırsaqdan gələn ammonyakın qaraciyərdən yan keçməsi. Hər iki hal da, qaraciyərin zərərsizləşdirmə imkanlarının zəifləməsini göstərdiyi üçün ammonyakın qanda tə'yini, qaraciyərin funksional vəziyyətini qiymətləndirməyə imkan verir. Ammonyakın qanda normal miqdarı 11-32 $\mu \mathrm{mol} / \mathrm{L}$ arasındadır. Ancaq, ammonyakın mövcud müayinə üsullsrı istiliyə, havaya çox həssas olduğu üçün nəticələri dəyişdirə bilir.

Bromsulfalein sınağı hepatositlərdə konyuqasiya, ekskresiya və öd ifraz olunma proseslərini göstərir. Bromsulfalein hepatositlərdə qlütation ilə birləşərək ödlə ifraz olunur. Xəstəyə vena daxilinə $5 \mathrm{mg} / \mathrm{kg}$ dozada bromsulfalein vurulur və 2, 3, 20 və 45 dəqiqə sonra qanda bromsulfaleinin miqdarı ölçülərək onun qandan təmizlənmə sür’əti (kliriensi-qatılığın vahid zamanda azalması) hesablanır. Normada bromsulfalein klirensi 9-10\% 
/dəq. və ya retensiyonu 45-ci dəqiqədə $<30 \%$ təşkil edir. Hepatositlərdə ciddi zədələnmələr olduqda konyuqasiya və intrahepatositar daşınmanın, xolestatik sarılıklarda isə, ifrazın pozulması ilə əlaqədar, klriens kəskin zəifləyir. Xolestaz olmayan hallarda hepatositlərin funksiyasını daha düzgün qiymətləndirməyə imkan verir. Qaraciyərdə bilirubini birləşdirən fermentlərin yoxsulluğu olan hallarda (Krijler-Najjar, Gilbert sindromları) bromsulfaleinin kliriensi azalır. Dabin-Jonson sindromunda (hepatositlərin ekskretor funksiyasının pozulması) əvvəlcə bromsulfaleinin qanda miqdarı azalır ( konyuqasiya prosesləri normaldır), 45 dəq. sonra isə, təkrar artmağa başlayır. Allergik reaksiyalar, tromboflebit, damardan kənara çıxdıqda isə nekroz törədə bilir. Bromsulfalein bilirubin kimi entero-hepatik dövrana daxil olduğundan, bu sınaq yanılıș nəticələr verə bilər.

İndosianin yaşıl boyası (ISY) sınağı. Qaraciyərin qan təhcizatını və ekskretor funksiyasını göstərir. ISY qandan sür'ətli şəkildə qaraciyər tərəfindən tutulur və heç bir biotransformasiyaya uğradilmadan öd yollarına atılır. Bromsulfaleindən fərqli olaraq İSY entero-hepatik dövrana daxil olmur. Xəstəyə vena daxilinə $0,5 \mathrm{mg} / \mathrm{kg}$ dozada İSY vurulur və $15 \mathrm{dəq}$. sonra qan alınaraq birbaşa və ya qulaqda fotometrik üsulla boyanın miqdarı ölçülür. Sınağı müxtəlif dövrlərdə təkrarlayaraq "ISSY indeksini”"- nisbətləri də istifadə oluna bilər. Normada 15 dəq. sonra İSY qandak1 miqdar $1<10 \%$ olur. Boyanın qandan təmizlənmə vaxtının uzanması, yəni retensionunun $10 \%$ artıq olması qaraciyərdə qan dövranının pozulmasını, hepatosellülar yetməzliyi göstərir. İSY sınağından qaraciyər rezeksiyalarında, köçürülməsində və bir çox xəstəliklərində hepatositlərin funksiyasını tə"yin etmək üçün geniş istifadə olunur.

Lidokain sınagı qaraciyərdə başlıca detoksikasiya sistemi olan mikrosomal oksidaza siteminin funksional vəziyyətini qiymətləndirmək üçün istifadə olunur. Lidokain qaraciyərdə olan Sitoxrom P-450 sistemində oksidləşərək monoetilglisinksilidinə çevrilir (MEQK). Lidokain verildikdən sonra qanda MEQK tə'yin etməklə lidokainin oksidləşmə intensivliyi və beləliklə, qaraciyərdəki oksidaza sisteminin vəziyyəti haqqında mə'lumat almaq olur. Lidokain venadaxilinə $1 \mathrm{mg} / \mathrm{kg}$ dozada verilir, 15, 30, 60 dəq. sonra qanda MEQK qatılığı ölçülür. Normada 15-ci dəqiqədə MEQK miqdarı 117 mg/ml-dən çox olur. MEQK miqdarının azalması qaraciyərdə 
Sitoxrom P-450 sisteminin yetməzliyini göstərir. Bu sinaqdan sirrozun ağırlıq dərəcəsini, qaraciyər köçürülməsindən öncə və sonra qaraciyərin funksional vəziyyətini qiymətləndirmək üçün istifadə edilir.

Qaraciyərin zərərsizləşdirmə funksiyasını qiymətlənditmək üçün əvvəllər istifadə edilən koffein, asetoaminofen, amidopirin, hippur turşusu sınaqları İSY və lidokain sınaqlarına görə az həssas olduqları üçün hazırda çox az tətbiq edilirlər.

\section{QARACIYORİN ENERGETIK-METABOLIKK FUNKSIYYASI}

Energetik-metobolik funksiyası adı altında qaraciyərdə energetik maddələrin metabolizmi və bu maddələrin orqanizm hüceyrələri tərəfindən alına billəcək şəkilə salınması prosesləri nəzərdə tutulur. Bilindiyi kimi, hüceyrələr başlıca enerji substratı kimi glükoza, trigliseridlər, yağ turşuları və keton cisimciklərindən istifadə edirlər ki, bunlar da başlica olaraq, qaraciyərdə sintez olunurlar. Bundan başqa, qaraciyərdə baş verən proseslərin normal gedişi üçün də, hüceyrədaxili energetik maddələrə (ATF, kreatinin fosfat) ehtiyac vardır. Qaraciyərin energetik funksiyasını qiymətləndirilmək üçün müxtəlif müayinə üsullarından istifadə edilir: qanda qlükoza, yă̆ turşuları, keton cisimciklari, keton cisimciklari nisbati (KCN ), qaraciyər toxumasında qlükogen, ATF miqdarl, qalaktoza testi vo $s$. Bu müyinələrin əsasında başlica olaraq 2 prinsip durur. Birinci prinsipə görə, energetik substratın qatılığı onu əmələ gətirən və ya istifadə edən katobolitik mərhələ haqqında mə'lumat verir. Qanda qlükozanın, yă turşularının, keton cisimciklərinin, qaraciyər toxumasında qlükogenin, ATF miqdarının tə"yini və qalaktoza testi bu prinsipə əsaslanmişdır. İkinci prinsip, katobolizm prosesinin bir mərələsində baş verən pozğunluq nəticəsində bu mərhələyə daxil olan maddənin artması və çıxan maddənin isə azalması ilə əlaqədar, bu maddələrin miqdarının müqayisəsinə əsaslanır. Keton cisimcikləri nisbətinin tədqiqi bu prinsiplə bağlıdır.

Arteriyal keton cisimlori nisboti. Keton cisimcikləri üç maddədən təşkil olunmuşdur: asetilasetat turşusu, aseton və 3-hidroksiyağ turşusu. Mə'lumdur ki, normada çox az miqdarda, Krebs dövranının yetməzliyində 
(acliqda nisbi, zədələnmələrdə isə mütləq) isə, çoxlu miqdarda keton cisimcikləri əmələ gəlir. Asetilasetat turşusu asetil CoA -dan əmələ gələn ilk keton cisimciyidir. Asetilasetat turşusu spontan olaraq asetona və ya NADH (Nikotinamid adenin dinukleotit) iştirakı ilə 3-hidroksiyağ turşusuna çevrilir. Asetilasetat turşusu və 3-hidroksiyağ turşusu qaraciyərdə energetik substrat kimi istifadə olunmur, asanlıqla qana keçirək digər orqanlara paylanar və burada enerji üçün istifadə edilirlər ${ }^{2}$. Normada NADH konsentrasiyası aşağı olduğundan 3-hidroksiyağ turşusu az əmələ gəlir və asetilasetat / 3-hidroksiyağ nisbəti 1-dən böyük olur. Qaraciyərdə $\mathrm{NADH}$ artıklığı olan hallarda (oksidləşdirici-fosforlaşmada blok ) isə asetilasetat turşusunun çox hissəsi 3-hidroksiyağ turşusuna çevrilir və asetilasetat / 3-hidroksiyağ nisbəti 1-dən kiçik olur. Beləliklə, qanda asetilasetat / 3-hidroksiyağ nisbəti qaraciyərdə NAD+ / NADH nisbətini əks etdirir və qaraciyərdə oksidləşdirici-fosforlaşma proseslərini qiymətləndirməyə imkan verir. Bundan başqa, asetilasetat və 3-hidroksiyağ turşularının ümumi miqdarı Krebs dövranının vəziyyətini göstərə bilir. Qaraciyər xəstəliklərində, əməliyyatlarında, travma və sepsisdə qanda asetilasetat / 3-hidroksiyağ nisbəti 1-dən aşağı düşməsi qaraciyərin energetik yetməzliyini göstərir və ciddi müalicə tədbirləri tələb edir.

Qalaktoza sınağı qaraciyərdə energetik vəziyyəti, xüsusən ATF miqdarını qiymətləndirmək üçün istifadə edilir. Qalaktoza qaraciyərdə qalaktokinaza fermentinin tə'siri və ATF iştirakı ilə fosforlaşmaya mə'ruz qalır. Qalaktozanın qanda azlma intensivliyinə görə qaraciyərdə ATF-in miqdarı haqqında mə'lumat alınır. Venadaxilinə $0,5 \mathrm{~g} / \mathrm{kg}$ qalaktoza verildikdən 15, 30, 60 dəq sonra qalaktozanın qandakı miqdarı ölçülərək metobolizm intensivliyi tə'yin olunur. Qalaktozanın qandan təmizlənməsinəki azalma qaraciyərdə ATF azlığını göstərir. Normada qalaktozanın qandan təmizlənmə sür'əti $8 \mathrm{mg} / \mathrm{kg} / \mathrm{d} ə q$.-dən çox olur. $\mathrm{Bu}$ sınaqdan qaraciyər xəstəliklərinin ağırlıq dərəcəsini tə'yin etmək, qaraciyər köçürülməsində isə, orqanın energetik imkanlarını qiymətləndirmək üçün istifadə edilir.

\footnotetext{
${ }^{2}$ Sinir va azalo toxumalarından farqli olaraq qaraciyərd a asetilasetat vo 3-hidroksiya $\breve{g}$ turşularını Asetil-CoA-ya çeviran ferment yoxdur
} 
Glükoza, yăg turşuları, triqliseridlərin qandakı miqdarı bir çox amillərdən asılı olduğuna görə, qaraciyər üçün yüksək spesifikliyə malik deyillər.

\section{SEKRETOR FUNKSIYA GÖSTORICILORİ}

Öd sekresiyası mürəkkəb, ardıcıl proses olub, hepatositlər, öd axacaqlar və sfinktorlarının birgə fəaliyyəti nəticəsində həyata keçirilir. Hepatositlər ödün öd kapillyarlarına sekresiyasını, kapillyarlar və axacaqlar isə, ritmik peristaltika ilə ödün distala verilməsini, sfinktorlar və öd kisəsi isə, bağırsağa uyğun miqdarda keçməsini tə'min edirlər. Öd sekresiyasının pozulması başlıca olaraq durğunluq- xolestaz şəklindo ortaya çıxır. Hepatositlərdə və öd kapillyarlarında baş verən durğunluq intrahepatik, axacaqlardakı durğunluq isə, ekstrahepatik xolestaz adlanır.

Xolestaz ödün tərkibindəki maddələrin qana keçməsinə, öd yolları epitelinin zədələnməsinə səbəb olur. Xolestazda öd yollarının zədələnməsinin bir neçə mexanizmi ehtimal edilir. Axacaq daxilində təzyiqin artması, birbaşa və ya axacağın qan dövranını pozaraq zədələnmə törədir. Öd turşuları lipolitik tə'sirə, yə'ni yağları həlletmə - "sabun effektinə" sahibdirlər. Öd turşuları diğər hüceyrə membranları kimi, fosfolipidlərdən təşkil olunmuş epitel membranını zədələyə bilirlər. Nəticədə membran tərkibindəki və hüceyrə sitozolundakı maddələr xaricə çıxaraq qana keçirlər.

Belalikla, xolestazda bir tərəfdən ödün tarkibindəki maddəlarin, diğar tərəfdən isə, öd epiteli membranlart va sitozolundakı maddəlorin qana keçməsina yol açır. Xolestazın laborator diaqnostikası bu maddələrin qandakı miqdarlarının hesablanmasına ssaslanmışdır.

Birləşmiş bilirubinin, öd turşularının, membrana birləşmiş enzimlərin-qələvi fosfataza, QQT, 5-nukleotidazanın qandakı səviyyələrinin müəyyən edilməsi sekretor funksiyanın qiymətləndirilməsi üçün ən çox istifadə edilən göstəricilərdir.

Bilirubin haqqında yuxarıda mə'lumat verilmişdir. Onu qeyd etmək lazımdır ki, birləşməmiş bilirubin daha çox hemolizi və qaraciyərin 
detoksikasiya funksiyasını qiymətləndirmək üçün, birləşmiş bilirubin isə, sekretor funksiyanı müəyyən etmək üçün istifadə edilir.

Öd turşularının qandakı səviyyəsi xolestazı qiymətləndirmək üçün ən həssas üsullardan biridir. Normada deoksixol turşusunun səviyyasi 0,230,89 mikromol/l, Xenodeoksixol turşusununku 0-1,61 mikromol/l, xol turşusununku isə, 0,08-0,91 mikromol/l taşkil edir. Lakin öd tuşularının qanda tə'yini bahalı və çətin olduğu üçün geniş yayılmamışdır.

Qələvi fosfataza (QF) oksər toxumalarda tapılan, lakin daha çox hepatositlərin, öd epitelinin membranlarında və sümüklərdə yerləşmiş fermentdir, birləşmələrin fosforlaşması və fosfordan ayrılmasını kataliz edir.

Normal halda QF-nın qandakı səviyyəsinin ölçülmə metodundan asıl1 olaraq 40-150 TV/L və ya 30-90 TV/L arasında dəyişir. Uşaqlarda və hamilələrdə böyümə prosesi ilə əlaqədar QF səviyyəsi yüksəkdir.

Qəlavi fosfatazanın qanda artması asasən sümüklardo, qaraciyərdo prolifrativ proseslari vo öd yollarında tıxanma ila alaqadar baş verə bilir. Proliferativ proseslərdə QF-nin artması enzimin sintezindəki artma ilə əlaqədar baş verir. Xolestazda artması isə, epitelin zədələnməsi, öd turşularının "sabun effekti" nəticəsində meydana gəlir. Hepatositlərdəki zədələnmələrdə də QF arta bilər, lakin spesifik deyildir. QF qaraciyər şişlərində, postnekrotik və ya postrezeksiyon regenerasiyada və xolestazda artır. Sümüklərdə mübadilənin sür'ətlənməsi- regenerasiya, osteomalyasiya və s. hallada da artır. QF artmasının qaraciyər yoxsa sümük mənşəli olmasınıayırd etmək üçün zədələnmə göstəricilərinə, diğər xolestaz göstəricilərinə və kalsium miqdarına baxmaq lazımdır. Kalsium səviyyəsində, xüsusən də ionlaşmış sərbəst kalsium miqdarındakı dəyişikliklər, uşaqlarda QF artmasının sümük mənşəli olduğu ehtimalı yüksəkdir. Xolestazda QF ilə bərabər diğər membrana-bağl1 enzimlər (QQT, 5-NT) artır. Qaraciyər şişlərində və regenerasiyasında QF artması diğər enzimlərdə dəyişikliklər və alfa-fetoprotein səviyyəsində artma ilə müşahidə edilir.

5-Nukleotidaza (5-NT) enzimi əksər toxumalarda rast gəlir və ən çox sitoplazmatik mebranlarla birləşmiş şəkildə olur. 5-NT öd yollarını qiymətləndirmək üçün ən spesifik indikatorlardan biridir. QQT-dən fərqli olaraq hepatosit zədələnmələrində artmır, ALP-dən fərqli olaraq uşaqlarda, 
hamilələrdə və sümük xəstəliklərdə artmır. Normada 5-NT səviyyəsi 2-17 TV/L-dir. Bu saviyyənin 2 dəfadən çox artması xolestazı göstarən spesifik göstaricilardan biridir.

Belokiklo, qaraciyorin sekretor funksiyasını qiymotlondirmok üçün öd torkibindoki maddolorin (birloşmiş bilirubin, öd turşuları) vo membrana bağlı enzimlorin (QQT, QF, 5-NT) qandakı saviyyalori ölçülür.

\section{ŞIŞ VO VIRUS MARKERLORI}

Alfa-fetoprotin - embrional hüceyrələr tərəfindən sintez olunan zülaldır. Embrional dövrdə qanda tapılır, doğulduqdan bir neçə həftə sonra isə, müəyyən edilmir. Yaşlılarda səviyyəsinin artması embrional tipli hüceyrələrin aktif çoxalmasını göstərir. Hepatosellular xərçəngdə, postnekrotik, postrezeksiyon regenerasiya dövründə adətən qanda müəyyən edilir. Fibrolamellar tipli hepatosellular xərçəngdə isə, səviyyəsi yüksəlmir. Alfa-fetoprotein xayalığın və yumurtalıqların embrional şişlərində də artır.

Hepatosellular xərçəng radikal rezeksiya edildikdə alfafetoproteinin qanda səviyyəsi azalır. Lakin, residivlər baş verdikdə təkrar artır. Ona görə də, bu göstəricidən ən çox rezeksiya olunmuş xəstələrdə residivi yoxlamaq üçün istifadə edilir.

Hepatit törədən virusları müəyyən etmək üçün qanda və toxumalarda virusların antigenləri, nuklein turşularını virusa qarşı anticismlər tə'yin edilir. Corrahi praktikada qanla yayılan B və C virusları mühüm əhəmiyyət daşıyır. Cərrahın, xəstəxana işçilərinin və xəstələrin yoluxmasının qarşısını almaq və hepatiti olan xəstələrin vaxtında müalicəsi üçün xəstələrdə ən azı $\mathrm{B}$ və $\mathrm{C}$ viruslarını araşdırmaq lazımdır. Bunun üçün ilk mərhələdə $\mathrm{B}$ virusu üçün səthi antigeni $-H B s A g$, C virusu üçün isə, Anti$H B C$ anticisimini axtarmaq lazımdır. Bunların pozitiv olduğu hallarda xəstəliyin hansı fazada olduğunu müəyyən etmək üçün virusların diğər antigen və anticisimlərini nuklein turşularını araşdırmaq lazım gəlir (Codvol 2.1).

Cadval 2.2

Virus markerləri və klinik interpretasiyası. HBsAg sathi antigen, $H B e A g$ və HBcAg nüva anigenlari. 
Nuru Yusifoğlu Bayramov. Qaraciyər rezeksiyast

\begin{tabular}{|l|l|}
\hline Marker & Ohəmiyyəti \\
\hline HBsAg + & Virusun olduğunu göstərir : kəskin ,xronik, \\
& latent \\
Anti-HBs & Tam sağalmanı göstərir \\
HbeAg + & Virusun replikasyonunu göstərir \\
Anti-HBe & Rekonvalensasiyanın başlanması \\
& Davam edən infeksiya \\
HBcAg + & Virusun olduğunu göstərir \\
Anti-HBc IgM & Kəskin dövr (yüksək titirdə) \\
& Kəskinləşmə dövrü (az titirdə ) \\
Anti-HBc IgG & Sağalma (HBsAg- olarsa ) \\
& Xronik hepatit (HBsAg+ olarsa) \\
HBV DNA & Davam edən infeksiya \\
Fermentemiya & Qaraciyər zədələnməsi : \\
& Kəskin və xronik hepatitlər \\
\hline
\end{tabular}

Kəskin və kəskinləşmiş xronik virus hepatitləri qaraciyər rezeksiyasına əks göstərişdir. Donor kimi nəzərdə tutulan adamlarda virusla yoluxma əlaməti varsa, klinik gedişindən asılı olmayaraq bunlardan qaraciyər parçası almaq olmaz. Çünki, bu halda alıcının yoluxmasından başqa köçürülən qaraciyərdə çox qisa zamanda hepatit və sirroz inkişaf edir.

\section{QARACIYOR XəSTӘLIKLəRININ LABORATOR SINDROMLARI}

Qaraciyərin çoxfunksiyalı oldüğü üçün müayinə üsulları da sayca çoxdur. Müxtəlif xəstəliklər qaraciyərin bir və bir neçə funksiyasında dəyişiklik törədə bilir. Eyni zamanda bir funksiyada baş verən pozulma bir neçə göstəricinin dəyişməsinə səbəb olur. Ona görə də, xəstəlik nəticəsində hans1 funksiyanın və nə dərəcədə pozulmasını müəyyən etmək üçün laborator göstəriciləri kompleks şəkildə qiymətləndirmək lazımdır. Komleks şəkildə qiymətləndirmə qaraciyərdəki patoloji prosesin xarakterini - sindromları müəyyən etməyə imkan verir. 
Laborator göstəricilər aşağıdakı qaraciyər sindromlarını aşkar etməyə şərait yaradır:

* Zadolonmo sindromu

* Hepatosellular yetmozlik sindromu

* Xolestaz sindromu

* $\quad$ Proliferativ sindrom

Zədələnmə sindromu hepatositlərdə nekrobioz və nekrozu göstərir və qanda hüceyrədaxili və membran enzimlərinin artması ilə biruzə verir. Zədələnmə sindromuna qaraciyərin əksər xəstəliklərində müşahidə edilir.

Olamətləri: $A L T$ 个, AST $\uparrow, Q Q T \uparrow$

Hepatosellular yetmazlik sindromu qaraciyər hüceyrələrinin funksiyalarını yerinə yetirməməsini göstərir. Yetməzlik ümumi və hissəvi şəkildə ola bilər.

Ümumi hepatosellular yetməzlik sindromu hepatositlərin əksər funksiyalarının- sintetik, detoksikasiya, energetik, sekretor- birlikdə pozulduğunu göstərir. $\mathrm{Bu}$ sindrom kəskin və xronik (sirroz) qaraciyər yetməzliyində, böyük həcmli qaraciyər rezeksiyalarından sonrakı ilk günlərdə müşahidə edilir.

Olamətləri :

* Abumin $\downarrow$

* Prealbumin $\downarrow$

* Protrombin $\downarrow$

$* \quad$ Xolinesteraza $\downarrow$

* Bilirubin $\uparrow$

* Ammonyak $\uparrow$

* Indosianin yaşıl $15>15$

* Qalaktoza tomizlonmosi $\downarrow$

* Keton cisimciklari $\uparrow$

* $\quad$ Asetoasetat/oksiya $\quad<1$ 
Hissavi hepatosellular yetmazliyinda bir funksiyada pozulma olur. $\mathrm{Bu}$ hal adətən xronik və anadangəlmə xəstəliklərdə bir fermentin və ya faktoru defisiti nəticəsində ortaya çıxır:

* Alfa-antitripsin defisiti - sirroz, emfizema

* Laxtalanma və əks laxtalanma faktorları defisitləri

* Dilson xəstəliyi- seruloplazmin defisiti nəticəsində toxumalara mis toplanmas1

* Gilbert sindromu - glükronil transferaza enzimi defekti nəticəsində qanda sərbəst bilirubinin artması

* Krijler-Najjar sindromu- glükronil transferaza enzimi defisiti nəticəsində qanda sərbəst bilirubinin artması

* Dubin-Jonson, Rotor sindromları - birləşmiş bilirubinin ifrazını həyata keçirən faktorların defisiti nəticəsində qanda birləşmiş bilirubinin artması.

Xolestaz sindromu hepatositlordə sekretor funksiyanın pozulması və öd yollarında tıxanma nəticəsində ortaya çıxır, öd tərkibindəki maddələrin və membran enzimlərinin qanda artması ilə biruzə verir. Laborator göstəricilər intrahepatik, yoxsa, obstruktiv olduğunu müəyyən edə bilmir. Bunun üçün USM lazım gəlir. Lakin, laborator müayinələrlə xolestazın ümumi və hissəvi olduğunu müəyyən etmək olar.

Ümumi xolestaz sindromu qaraciyərin böyük bir hisəsində öd sekresiyasının pozulduğunu göstərir və qanda həm öd tərkibi maddələrin, həm də membran enzimlərinin artması ilə biruzə verir.

Olamətləri:

$\begin{array}{ll}* & \text { Birloşmiş bilirubin } \uparrow \\ * & \text { Odd turşulart } \uparrow \\ * & Q F \uparrow \\ * & \text { QQT } \uparrow \\ * & 5-N T \uparrow\end{array}$

Hissəvi xolestaz sindromu qaraciyərin 1/3-ndən az hissəsində öd sekresiyası pozulduqda ortaya çıxır. Bu sindrom membran enzimlərinin 
artması ilə biruzə verir, bilirubin və öd turşuları isə, artmır. Çünki, xolestaz bölgəsindən qana keçən bilirubin və öd turşuları qaraciyərin normal hissəsi tərəfindən tutulub təmizləir.

Olamətləri:

$\begin{array}{ll}* & \text { Birloşmiş bilirubin-normal } \\ * & \text { Öd turşulart - normal } \\ * & Q F \uparrow \\ * & Q Q T \uparrow \\ * & 5-N T \uparrow\end{array}$

Proliferativ sindrom hepatositlərin sür'ətlə çoxalmasını göstərir. $\mathrm{Bu}$ sindrom postnekrotik, postrezeksiyon regenerasiyalarda və şişlərdə müşahidə olunur.

Olamətləri:

$\begin{array}{ll}* & \text { Alfa-fetoprotein } \uparrow \\ * & Q F \uparrow(Q Q T \text { vo } 5-N T \text { normaldır })\end{array}$

Belalikla, qaraciyərin laborator müayina göstəricilarinin kompleks şəkildə qiymətlandirilməsi laborator sindromları ortaya çıxarmă̆a imkan verir ki, bu da patoloji proseslərin xarakterini müəyyən etməyə kömək göstarir.

\section{ӘDӘВIYYAT}

\section{QARACIYYRIN GÖRÜNTÜLӘMӘ ÜSULLARI}

1. Agildere AM, et al. MRI of hydatid disease of the liver: a variety of sequences. J Comput Assist Tomogr. 1998 Sep-Oct;22(5):718-24.

2. Borgonovo $\mathrm{G}$, et al.Pseudotumor of the liver: a challenging diagnosis. Hepatogastroenterology. 1998 Sep-Oct;45(23):1770-3 
3. Born M, et al. MRI, CT and CT arterial portography in the diagnosis of malignant liver tumors in liver cirrhosis. Rofo Fortschr Geb Rontgenstr Neuen Bildgeb Verfahr. 1998 Jun;168(6):567-72.

4. Broglia L, et al. Computerized tomography, magnetic resonance, and nuclear medicine in the non-invasive diagnosis of focal nodular hyperplasia of the liver Radiol Med (Torino). 1998 Sep;96(3):218-25.

5. De Franco A, et al. Integrated diagnosis of liver angioma: comparison of Doppler color ultrasonography, computerized tomography, and magnetic resonance. Radiol Med (Torino). 1997 Jan-Feb;93(1-2):87-94

6. Finazzo M, et al. Focal liver lesions. A comparison betəeen magnetic resonance under base conditions and after a superparamagentic contrast medium. Radiol Med (Torino). 1998 Jun;95(6):599-607.

7. Fujino K, et al. A primary hepatic carcinoid tumor: evaluation by computed tomography and magnetic resonance imaging. Radiat Med. 1998 Sep-Oct;16(5):371-3.

8. Hinterthaner M, et al. Diagnosis of liver tumors--əhat is necessary for therapy planning? Zentralbl Chir. 1998;123(2):104-10.

9. Hori M, et al. Sensitivity in detection of hypervascular hepatocellular carcinoma by helical CT oith intra-arterial injection of contrast medium, and by helical CT and MR imaging əith intravenous injection of contrast medium. Acta Radiol. 1998 Mar;39(2):144-51

10. Hytiroglou $P$, et al. Differential diagnosis of hepatocellular nodular lesions. Semin Diagn Pathol. 1998 Nov;15(4):285-99.

11. Knol JA. ,et al. Comparision of dynamic infusion CT, intraoperative US and palpation in the diaqnosis of the liver metastasis. Am J Surg 1993:167:151-155

12. Palma LD. Diagnostic imaging and interventional therapy of hepatocellular carcinoma. Br J Radiol. 1998 Aug;71(848):808-18.

13. Reimer P, et al. Hepatic MRI əith SPIO: detection and characterization of focal liver lesions. Eur Radiol. 1998;8(7):1198-204 
14. Rofsky NM, et al. MR-guided needle aspiration biopsies of hepatic masses using a closed bore magnet. J Comput Assist Tomogr. 1998 JulAug;22(4):633-7.

15. Schunk K, et al. Diagnostic imaging of benign and malignant liver tumors: computerized tomography or magnetic resonance tomography? Zentralbl Chir. 1998;123(2):124-30

16. Siegelman ES, et al. Magnetic resonance imaging of focal and diffuse hepatic disease. Semin Ultrasound CT MR. 1998 Feb;19(1):2-34.

17. Solomon MJ, Stephen MS, Gallinger S, Ohite GH. Does intraoperative hepatic ultrasonography change surgical decision making during liver resection? Am J Surg 1994;168: 307-310

18. Takayasu K, Moriyama N, Muramatsu Y et al. The diagnosis of small hepatocellular carcinomas: efficacy of variose imaging procedures in 100 patients. Am J Radiol 1990; 155:49-54

19. Taylor HM, et al. Hepatic imaging. An overvieə.

Radiol Clin North Am. 1998 Mar;36(2):237-45

20. Vilgrain V. Imaging assessment before surgical resection. Ann Ital Chir. 1997 Nov-Dec;68(6):737-44.

\section{LABARATOR MÜAYINO ÜSULLARI}

1. Assessment of liver function. In: Sherlock S., Dooley J. Diseases of the liver and biliary system. Oxford 1997:17-33

2. Belghiti-J; Di-Carlo-I; Sauvanet-A; Uribe-M; Fekete-F. A ten-year experience aith hepatic resection in 338 patients: evolutions in indications and of operative mortality. Eur-J-Surg. 1994 May; 160(5): 277-82

3. Burdelski-M; Schutz-E; Nolte-Buchholtz-S; Armstrong-VӘ; OellerichM. Prognostic value of the monoethylglycinexylidide test in pediatric liver transplant candidates. Ther-Drug-Monit. 1996 Aug; 18(4): 378-82 
4. Capussotti-L; Borgonovo-G; Bouzari-H; Smadja-C; Grange-D; FrancoD. Results of major hepatectomy for large primary liver cancer in patients əith cirrhosis. Br-J-Surg. 1994 Mar; 81(3): 427-31

5. Hashimoto-M; Sanjo-K. Functional capacity of the liver after təo-thirds partial hepatectomy in the rat. Surgery. 1997 Jun; 121(6): 690-7

6. Hino I, et al. Index for predicting post-operative residual liver function by pre-operative dynamic liver SPET. Nucl Med Commun. 1997 Nov;18(11):1040-8.

7. Hu-RH; Lee-PH; Yu-SC; Dai-HC; Sheu-JC; Lai-MY; Hsu-HC; ChenDS. Surgical resection for recurrent hepatocellular carcinoma: prognosis and analysis of risk factors. Surgery. $1996 \mathrm{Jul} ; 120(1): 23-9$

8. Klein AS, Smith Gə. Diagnostic operations of the liver and techniques of hepatic resection. In: Shacklefors's Surgery of the Alimentary Tract, 1996 ed. Volume III: 578-599

9. Lai-EC; Fan-ST; Lo-CM; Chu-KM; Liu-CL; Oong-J. Hepatic resection for hepatocellular carcinoma. An audit of 343 patients. Ann-Surg. 1995 Mar; 221(3): 291-8

10. Makuuchi M. Surgical treatment of hepatocellular carcinoma. In: ArroyoV, Bosch J, Rodes J. Treatments in Hepatology. Masson, SA, Barcelone 1995, 341-352

11. Miyazaki M; Sugasaəa T; Itoh $H$. et al. Significance of aminopyrine breath test as a parameter of hepatic functional reserve in $40 \%$ partial hepatectomy of rats aith CCl4-induced liver injury. Res Exp Med (Berl). 1995. 195(2). P 69-75.

12. Nagasue-N; Yukaya-H; Ogaəa-Y; Sasaki-Y; Chang-YC; Niimi-K. Clinical experience aith 118 hepatic resections for hepatocellular carcinoma. Surgery. 1986 Jun; 99(6): 694-701

13. Nagasue N; Uchida M; Kubota H; Hayashi T; Kohno H; Nakamura T. Cirrhotic livers can tolerate 30 minutes ischaemia at normal environmental temperature. Eur J Surg. 1995 Mar. 161(3). P 181-6.

14. Noack KB, et al. Investigation of the patient əith abnormal liver function tests. Baillieres Clin Gastroenterol. 1997 Mar;11(1):83-95 
15. Okamoto-E; Kyo-A; Yamanaka-N; Tanaka-N; Kuəata-K. Prediction of the safe limits of hepatectomy by combined volumetric and functional measurements in patients ith impaired hepatic function. Surgery. 1984 May; 95(5): 586-92

16. Pelton JJ, et al. Comparison of liver function tests after hepatic lobectomy and hepatic əedge resection. Am Surg. 1998 May;64(5):40814.

17. Pinkerton JA, Saəyers JL, Foster JH. A study of the postoperative course after hepatic lobectomy. Ann-Surg 1971: 173 (5): 800-811

18. Pitre-J; Houssin-D; Kracht-M. Resection of hepatocellular carcinomas. Analysis of prognostic factors of a multicenter series of 153 patients Gastroenterol-Clin-Biol. 1993; 17(3): 200-6

19. Pugh RNH, Murray-Lyon IM, Daəson JL et al. Transection of the oesophagus for bleeding oesophageal varices. Br J Surg 1973; 60:646649.

20. Riordan SM, et al. Preoperative investigation and indication for operation in hepatocellular carcinoma. J Hepatobiliary Pancreat Surg. 1998;5(1):1-6

21. Schinella M; Guglielmi A; Veraldi GF et all. Evaluation of the liver function of cirrhotic patients based on the formation of monoethylglycine xylidide (MEGX) from lidocaine. Eur J Clin Chem Clin Biochem. 1993 Sep. 31(9). P 553-7.

22. Segaəa T, Tsuchiya R, Furui J et al. Operative results in 143 patients əith hepatocellular carcinoma. Đorld J Surg 1993;17(5): 663-667

23. Shimada-M; Matsumata-T; Akazaəa-K; Kamakura-T; Itasaka-H; Sugimachi-K; Nose-Y. Estimation of risk of major complications after hepatic resection. Am-J-Surg. 1994 Apr; 167(4): 399-403

24. Stone MD, Benotti PN. Liver resection. Preoperative and postoperative care. In: Liver resection.Surg-Clin-North-Am, 1989: 69(2): 383-392

25. Textbook of Surgery. D C Sabiston. 14-th ed. 1991 p:1017. 
26. Tiao GM, Fisher JE. Preoperative management and nutrition in patients aith liver an biliary tract desease. Shacklefors's Surgery of the Alimentary Tract, 1996 ed. Volume III: 578-599

27. Đilliams R. Treatment of acute liver failure. In: ArroyoV, Bosch J, Rodes J. Treatments in Hepatology. Masson, SA, Barcelone 1995, 365374

28. コu-CC; Ho-ӘL; Yeh-DC; Huang-CR; Liu-TJ; P'eng-FK. Hepatic resection of hepatocellular carcinoma in cirrhotic livers: is it unjustified in impaired liver function? Surgery. $1996 \mathrm{Jul} ; 120(1)$ : 34-9

29. Yamanaka-N; Okamoto-E; Oriyama-T; Fujimoto-J; Furukaəa-K; Kaəamura-E; Tanaka-T; Tomoda-F. A prediction scoring system to select the surgical treatment of liver cancer. Further refinement based on 10 years of use. Ann-Surg. 1994 Apr; 219(4): 342-6

30. Yamanaka N; Okamoto E; Kaəamura E et all. Dynamics of normal and injured human liver regeneration after hepatectomy as assessed on the basis of computed tomography and liver function. Hepatology. 1993 Jul. 18(1). P 79-85.

31. Zoedler-T; Ebener-C; Becker-H; Roeher-HD. Evaluation of liver function tests to predict operative risk in liver surgery. HPB-Surg. 1995; 9(1): $13-8$ 
III Bölüm

\section{QARACIYYR REZEKSIYYASINA GÖSTORISŞLOR Və OKS GÖSTORIȘLOR}

Qaraciyər rezeksiyası ağır və travmatik əməliyyatlardan biri olub ağırlaşma halları yüksək olan müalicə metodudur. Ona görə də, rezeksiya qərarını verərkən, bu əməliyyatın törədə bildiyi ağırlaşmalar və müalicə effekti nəzərə alınmalıdır. Qaraciyər rezeksiyası qərarını vermək üçün üç məsələ ciddi və obyektiv bir şəkildə həll edilməlidir.

1. Xostolik rezektabeldirmi?

2. Qaraciyor rezektabeldirmi?

3. Xosto rezektabeldirmi?

Xəstəlik rezektabelliyi dedikdə qaraciyərdə olan patoloji mənbənin çıxarılmasının lazım olub-olmadığı, texniki olaraq mümkün olması və xəstənin bundan fayda görməsi məsələləri nəzərdə tutulur. Xəstəliyin rezektabelliyini müəyyən edən amillər xəstaliyin təbiati və yaylma dərəcəsidir. Başqa sözlə, xəstəliyin təbiəti rezeksiyaya göstərişi müəyyən edirsə, yayılma dərəcəsi isə, əks göstərişi müəyyən edir.

Qaraciyər rezeksiyasına göstərişi təşkil edən xəstəliklər başlıca olaraq yerli xəstəliklər olub ədəbiyyatda yer tutan xəstəliklər, törəmələr adlandırılır. Törəmə termini adətən yerli böyüməni ifadə etmək üçün istifadə olunur. Lakin, burada həm yerli böyümə, həm də yerli kiçilmə tipli xəstəliklər törəmə adı altında veriləcək.

Qaraciyər törəmələrinin müxtəlif təsnifatı mövcuddur. Klinik praktikada ən çox istifadə edilən klinik-morfoloji təsnifatdır (Sxema 3.1). Bu təsnifata görə qaraciyər törəmələri kistik, töxumalı, kalsifikasyon, və qarışıq tiplərə ayrılır. 
Qaraciyar rezeksiyasına göstorişlor va oks göstorişlor

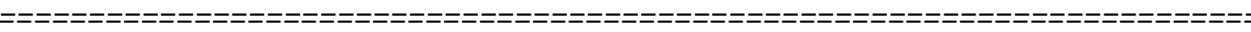

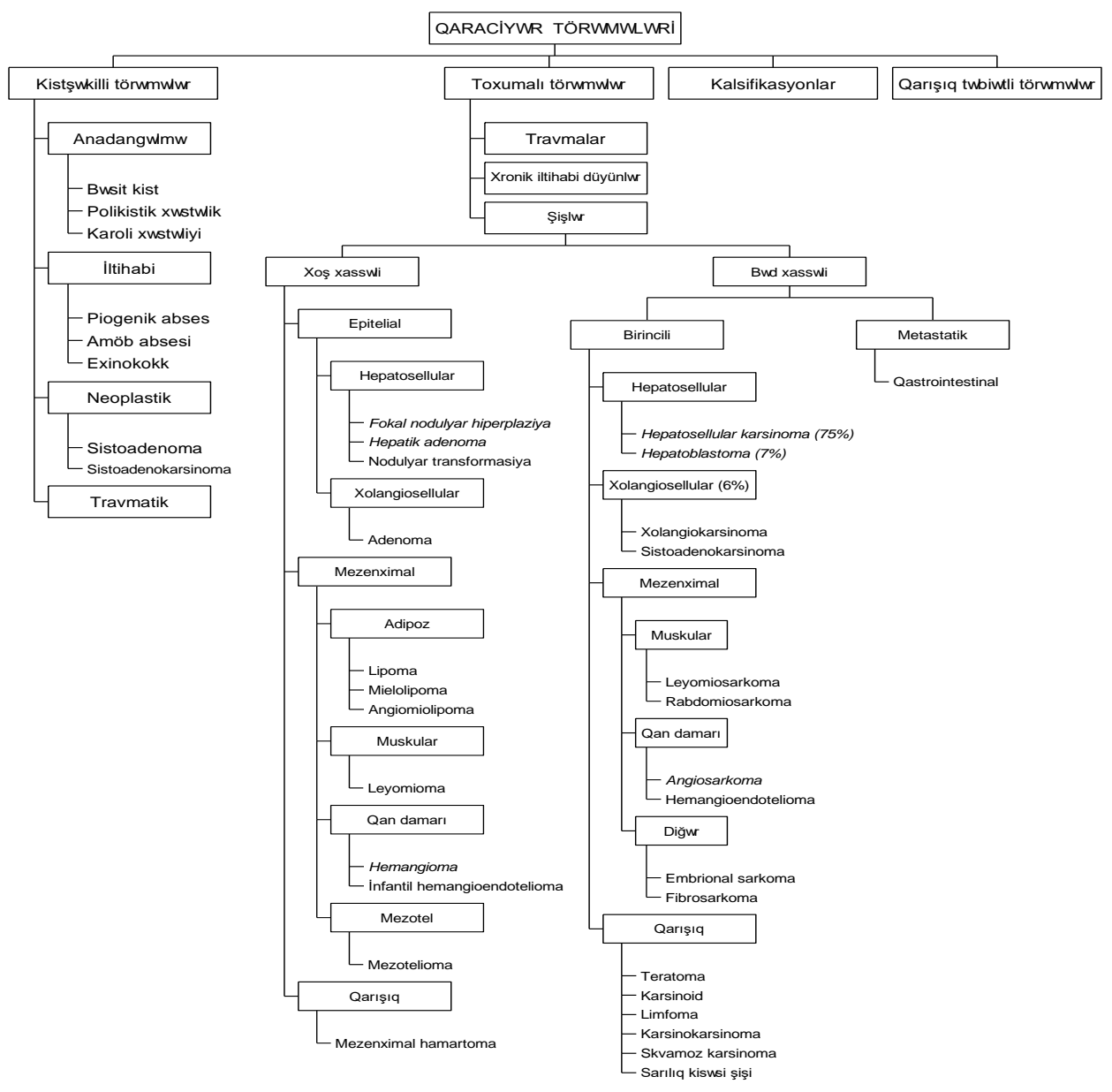

Sxema 3.1. Qaraciyər törəmələrinin təsnifat1 


\section{QARACIYORIN KISTŞəKILLI TÖRəMӘLəRI (SULUQLARI)}

Qaraciyərin "kist" və ya "suluq" adlanan maye tərkibli törəmələri müxtəlif səbəbli və təbiətli olsalar da, aşağıdakı bir çox ümumi cəhətləri vardir:

1. Kistlər USM, BT və ya MRG-də maye tərkibli hipointensiv (hipo-, anekoik, hipodens, hipointens) görünürlər.

2. Kistlərin əsas əlamətləri ətraf orqanlara təzyiq və ağırlaşmaqanaxma, absesləşmə, boşluqlara açılma- əlamətləridir.

3. Asimptomatik şişlər təsadüfü müayinədə tapılır və bə’zi hallarda müalicə yox, müşahidə tələb edirlər.

4. Simtomatik və ağırlaşmış kistlər adətən müalicə tələb edir və müalicə üsulları kistin təbiətindən asılıdır.

Bu səbəblərə görə kistləri ümumi başlıq altında müzakirə etmək məqsədəuyğundur. Lakin, kistlərin təbiətini ortaya ç1xarmaq və differensial diaqnostika məqsədi ilə onları ayrı-ayrılıqda əhatə etmək də lazımdır.

Qaraciyər kistləri etio-patogenetik cəhətlərinə görə anadangəlmə, parazitar, neoplastik, travmatik və iltihabi kistlərə ayrılırlar.

\section{ANADANGOLMO KISTLOR}

Anadangəlmə kistlərin divarı üçqatlı olub, daxildə öd yolları tipində epitel, ortada epitel membranı və xaricdə nazik fibroz təbəqədən ibarətdir. Epitel qişası andangəlmə kistlərin ən mühüm xüsusiyyətidir və kist içərisindəki mayeni ifraz edir. Ona görə də, epitel qişası sağlam olduqda kistlərin residivləşmə ehtimalı yüksək, obliterasiya imkanı isə çox azdır. Anadangəlmə kistlərin əmələ gəlməsində retensiyon mexanizmin, yə’ni ifraz edilən mayenin çıxmaması əsas amil hesab edilir. Müxtəlif anadangəlmə səbəblər- kistlə öd yolları arasında əlaqənin bağlı qalması, tıxanma və s. retensiyon törədə bilirlər.

Qaraciyərin anadangəlmə kistlərinin sayına, öd yolları ilə əlaqəsinə, qaraciyərdən başqa orqanda olub-olmamalarına görə bir çox klinik-morfoloji tipi vardır: 
Qaraciyar rezeksiyasına göstorişlor vo əks göstorişlor

1. Basit kist. Adətən tək kist olur, divarı incə, öd yolları ilə əlaqəsi yoxdur, qaraciər toxuması normal vəziyyətdədir. Ölçüsü millimetrdən bir neçə santimetrə qədər dəyişə bilir.

2. Polikistik xəstəlik. Qaraciyərdə iki və daha çox kist olur, əksər hallarda böyrəkdə və sümüklərdə də kistlər müşahidə edilir. Ağırlaşmayan kistlərin öd yolları ilə əlaqəsi yoxdur. Qaraciyər parenximasının təzyiqə mə'ruz qalmayan hissələri normaldır. Kistlərin ölçüləri adətən müxtəlif olub 1,5-20 sm arasında dəyişir, tərkibindəki maye isə eynidir.

3. Karoli xəstวliyi. Bütün qaraciyərdə və ya müəyyən nahiyədə intrahepatik öd yollarının genişlənməsi nəticəsində əmələ gələn çoxlu kistlər var, qaraciyər parenximası normaldır. Kistlər adətən kiçik ölçülü olub $(<5 \mathrm{sm})$, nadir hallarda böyük ölçülərə çatır. Kistlərin öd yolları ilə əlaqəsi olduğu üçün infeksiyalaşma ehtimalı yüksəkdir. Ona görə də, bu xəstəlikdə xolangitə çox rast gəlinir. Karoli xəstəliyi kongenital hepatik fibrozislə birlikdə rast gəlinə bilər.

Klinikast. Bəsit kist və polikistik xəstəlik əksər hallarda asimptomatik seyr edər və təsadüfi müayinələrdə ortaya ç1xarlar. Kistlər böyüyərək ətrafa təzyiq göstərdikdə və ya ağırlaşma inkişaf etdikdə klinik əlamətlər ortaya çıxır. Təzyiq əlamətləri qarında kütlə, diskomfort hissi, nadir hallarda sarılıq və portal hipertenziya əlamətləridir. Kist içərisinə qanaxma olduqda kütlənin birdən-birə böyüməsi, ağrı və anemiya müşahidə edilir. İnfeksiyalaşma abses klinikası şəklində- ağrı, atəş, üşütmə və diğər septik əlamətlərlə biruzə verir. Bəsit kistdə və polikistik xəstəlikdə malignizasiya çox nadirdir. Bəsit kistdən fərqli olaraq polikistik xəstəlikdə qaraciyər əlamətlərindən daha çox, böyrək əlamətləri ön plana çıxır. Bunlarda böyrək yetməzliyi, pielonefritlər ən çox rastlanan ağırlaşmalardır.

Karoli xəstəliyi üşaq və genc yaşlarda xolangit əlamətləri ilə ortaya çıxır: atəş, titrətmə, sarılıq, ağrı. Az hallarda asimptomatik olur. Bu xəstələrdə intrahepatik daşlara da rast gəlinə bilir.

Diaqnostikast. USM, BT və ya MRG bəsit kistlərin və polikistik xəstəliyin diaqnostikasında çox vaxt yetərlidir. Nazik divarlı, maye tərkibi 
olan, toxuma komponenti olmayan tək kist bəsit kistin xarakteristik əlamətidir. Bu tipli bir neçə kistin olması, böyrək və sümüklərdə kistlərin mövcudluğu polikistik xəstəlik üçün xarakteristikdir. Qaraciyərdə yayğın, kiçik ( $<5 \mathrm{sm})$ kistlərin xolangit klinikası ilə birlikdə olması Karoli xəstəliyinə şübhə yaradır. Retroqrad xolangioqrafiyada intrahepatik öd yollarının kistşəkilli genişlənməsi Karoli xəstəliyi diaqnozunu dəqiqləşdirir. Bə’zən xəstələrə sekretin verilir və öd ifrazına baxılır. Karoli xəstəliyində sekretindən sonra öd ifrazının artır, lakin bu əlamət diğər xəstəliklərdə də müşahidə edilə bilər.

Müalicəsi. Anadangəlmə kistlərin müalicə prinsipləri epitelin, ətrafa təzyiqin və ă̆ırlaşmaların aradan qaldırılmasıdır. Epitel qişasını aradan qaldırmaq üçün total kistektomiya və kist içərisinə sklerotik maddələrin (etanol, tetrasiklin) vurulması üsulları vardır. Otrafa təzyiqi azaltmaq üçün dəridən keçən punksiya və kist divarında pəncərə açaraq periton boşluğu ilə əlaqə yaratma (fenestrasiya) üsulları istifadə edilir.

Tək və çoxlu kistlərdə müalicə taktikası klinik forma və ağırlaşma növü ilə müəyyən olunur (Sxema 3.2). Təsadüfi müayinələrdə tapılan asimptomatik kistlər müşahidə edilməlidir.

Kist amaliyyat vaxtı tapılarsa ayaqcı̆̆ 1 olduqda asanlıqla çıxarılır. Ayaqcığı və öd yolları ilə əlaqəsi olmayan kistlərin sərbəst divarında 3-4 smlik pəncərə açılaraq mayenin periton boşluğuna keçməsi üçün şərait yaradılır. Kist mayesi transsudata yaxın və içərisində q1cıqlandırıcı maddələr olmadığ 1 üçün peritonda reaksiya törətmir və asanlıqla sorulur.

Simptomatik şişlərdə müxtəlif üsullar tətbiq edilir. Bə’zi klinisistlər dəridən keçən kateterizasiya və skleroterapiya üsuluna üstünlük 
Qaraciyor rezeksiyasına göstorişlor va oks göstorişlor

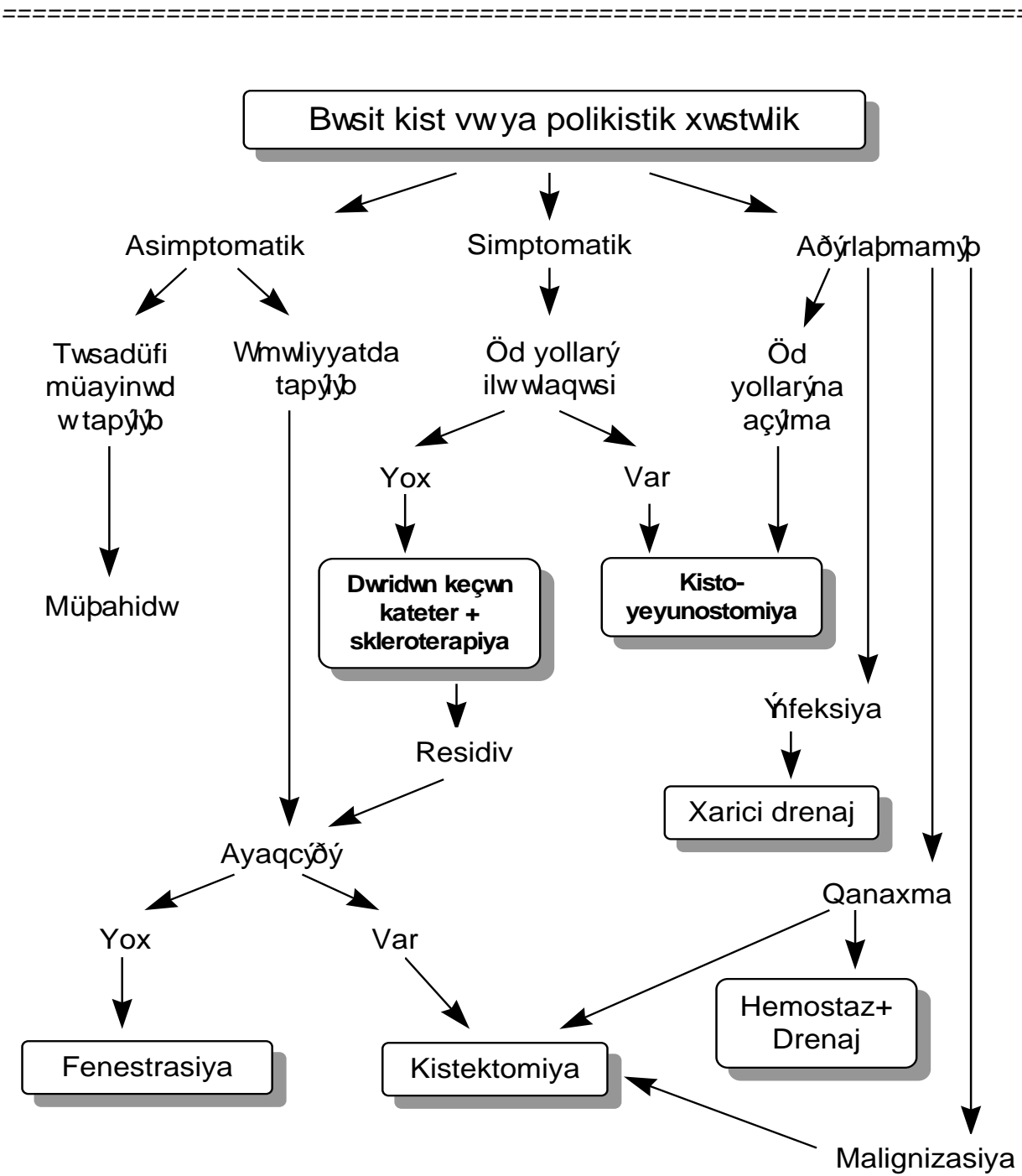

Sxema 3.2. Qaraciyərin anadangələmə kistlərində müalicə taktikası

verirlər. USM və ya BNT nəzarətində kist boşluğuna kateter yerləşdirilərək maye çıxarılır və kontrast vurulur. Kontrast öd yollarına keçmədiyi hallarda boşluğa sklerotik maddə (etanol, tetrasiklin) vurulur və 2-3 gün sonra kateter 
çıxarılır. Diğər müəlliflər isə, öd yolları ilə əlaqəsi olmayan kistlərin müalicəsi üçün açıq və ya laparoskopik üsulla fenestrasiya əməliyyatını tövsiyə edirlər. Kistin öd yolları ilə əlaqəsi olarsa kisto-yeyunostomiya əməliyyatı lazım gəlir.

Ağırlaşmış kistlərdə isə, ağırlaşmanın növündən asılı olaraq uyğun müalicə üsulu seçilir. İrinləmiş kistlərdə xarici drenaj, qanaxmalarda hemostaz+drenaj və ya kistektomiya, öd yollarına açılmış kistlərdə kistoyeyunostomiya, malginizasiyada isə, kistektomiya və ya rezeksiya tətbiq edilir.

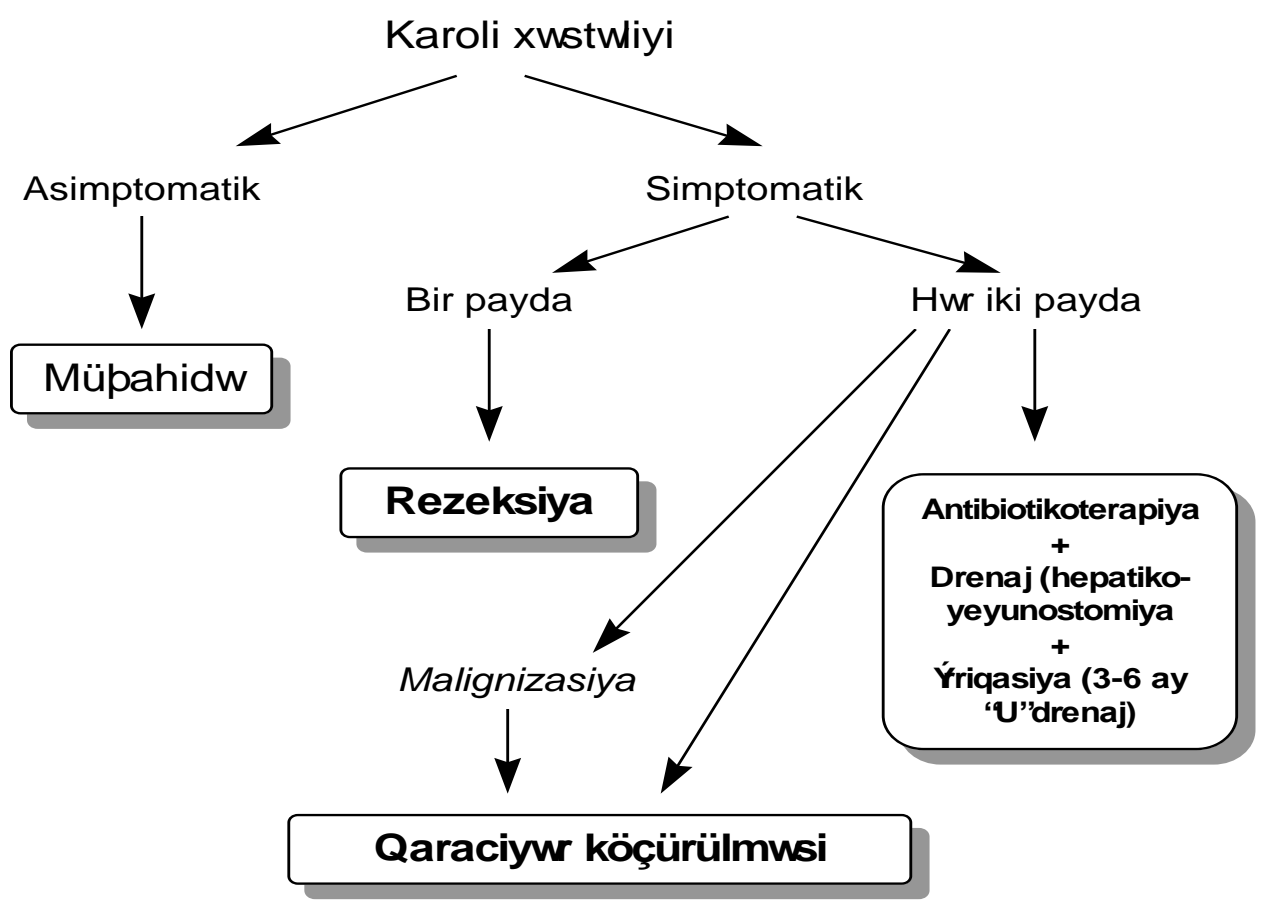

Sxema 3.3. Karoli xəstoliyindo müalicə taktikası 
Qaraciyar rezeksiyasına göstorişlor vo əks göstorişlor

Beləliklə, bəsit kist və polikistik xəstəlikdə rezeksiya az hallarda tələb olunur. Çünki, rezksiyaya va ya kistektomiyaya göstərişi təşkil edon malignizasiya basit kist va polikistik xastalikda nadir rast galir.

Karoli xəstəliyinin müalicəsi diğər kistik xəstəlikdən fərqlənir (Sxema 3.3). Asimptomatik hallarda müşahidə edilir. Simptomatik hallarda isə xəstəliyin yayğınlıq dərəcəsi əhəmiyyətlidir. Xəstəlik bir payı tutarsa, rezeksiya ən uyğun müalicə üsuludur. Hər iki payı tutan hallarda öd yollarının drenajı, daşların çıxarılması lazım gəlir. Bu xəstələrdə xolangit tez-tez təkrarladıqda qaraciyər köçürülməsi tövsiyə olunur.

\section{NEOPLASTIK KISTLOR}

Neoplastik kistlərə xoşxassəli sistoadenom və bəd xassəli sistoadenokarsinomalar aiddir. Bu kistlər nadir rast gəlir. Anadangəlmə kistlərdə olduğu kimi üçqatlıdırlar: epitel, epitel membranı və fibroz qat. Kistin epitel qatının hamısı və ya bir hissəsi neoplastik xarakterli olub mutsin tipli qatı maye ifraz edir. Epitel kist divarı boyunca böyüyərək divarın qalınlaşmasına və kistin içərisinə doğru böyüyərək papillamatoz çıxıntının əmələ gəlməsinə səbəb olur. Kistin bəd və ya xoş xassəli olması epitelin neplastik xarakterinə görədir. Neoplastik kistdə normal epitelin olmasına əsaslanaraq bunların anadangəlmə kistlərdən inkişaf etdiyi ehtimalı vardır. Sistoadenokarsinoma birincili olaraq qaraciyərdən və ya ikincili olaraq metastatik çənbər bağırsaq, pankreas, mə’də, böyrək, yumurtalıq şişlərində də rast gəlir.

Neoplastik kistlərin klinik əlamətləri bəsit kistlərə çox bənzəyir. Lakin, residiv və metastaz vermə ehtimalları yüksək olduğu üçün bu kistlərdə radikal kistektomiya və ya rezeksiya lazım gəlir. Ona görə də bəsit kistləri neoplastik kistlərdən ayırmaq vacibdir. Bir-birinə yaxın bir neçə kistin olması, içərisindəki mayenin müxtəlif sıxlıqlı, divarının qalın və kələkötür olması ilə yanaşı kist içərisində papillamatoz çıxıntılar kistin neoplastik xarakterli olduğunu göstərir. Kistin dəqiq diaqnozu isə mayedə və ya divarda şiş hüseyrələrinin tapılması ilə qoyulur.

Sistoadenomalarda kistektomiya və ya rezeksiya, birincili sistoadenokarsinomalarda isə, sağlam toxuma səviyyəsində rezeksiya lazımdır. İkincili sistoadenokarsinomalarda cərrahi müalicə metastatik 
şişlədə olduğu kimidir, yə'ni, ilkin mənbə çıxarıldığı və ekstrahepatik metastazlar olmadığı hallarda qaraciyərdəki kist çıxarıla bilər.

\section{TRAVMATIKK KISTLOR}

Travmatik kistlər kut, açıq travma, arterial infarktdan sonra qaraciyər parenximasına qanaxma, öd toplanması nəticəsində əmələ gələn psevdokistlərdir. Kistlərin divarı birləşdirici toxumadan ibarət olub, epitel qatı yoxdur (prevdokist- "yalançı kist"), içərsində isə qan və ya öd tapılır.

Travmatik kistlərin infeksiyalaşma ehtimalı yüksəkdir. Müalicəsi infeksiya inkişaf etdiyi hallarda xarici drenajdır.

\section{PARAZITAR KİSTLOR}

Exinokokk paraziti qaraciyərdə iki növ zədələnmə törədir. Echinococcus granulosae böyük kistlor -hidatitoz tip, Echinococcus alveolaris isə, xərçəngəbənzər mikrokistlər törədir. Kistik və ya hidatitoz tip ən çox rast gələn formadır. Alveolar tip isə çox nadir rast gəlir, əsasən Sibir və Alyaska bölgələrində müşahidə olunur.

\section{Hidatitoz (kistik) exinokokkoz}

Etiologiyast. E. granulosae 4-6 mm uzunluğunda qurddur, əsas sahibləri hesab edilən itlərin və pişiklərin nazik bağırsaqlarında yaşayırlar. İnsan və ot yeyən heyvanlar parazitin ara sahibləridirlər. Osas sahiblərin bağırsaqlarından bayıra atılan yumurtalar insanlar və ot yeyən heyvanlar tərəfindən udulur. Yumurtadan çıxan onkosferalar ara sahibin bağırsaq divarını keçərək qan və ya nadir hallarda limfa ilə daxili orqanlara çatırlar. Onkosferadan əmələ gələn skolekslər toxumada kistşəkilli törəmə əmələ gətirir. On çox qaraciyər, sonra ağciyər və diğər orqanlar tutulur.

Kistin quruluşu. Exinokokk kistinin üç təbəqəsi var: daxildə germinativ, ortada xitin, xaricdə isə fibroz qat. Germinativ qatda skolekslər çoxalır, maye ifraz edir və q1z qovucuqlar əmələ gətirirlər. Xitin qat (laminatıv) exinokokka məxsus, ağımıtıl rəngli, kövrək membrandır. Fibroz qat (perikist də adlanır) parazitin əmələ gətirdiyi qat olmayıb, əksinə, parazitə 
Qaraciyar rezeksiyasına göstorişlor vo əks göstorişlor

qarş1 orqanizm tərəfindən iltihabi reaksiya və ya kistin qaraciyərə təzyiqi ilə əlaqədar əmələ gələn birləşdirici toxumadır. Ovvəllər kistin quruluşuna görə iki əsas növü- monovezikulyar (təkqovucuqlu) və multivezikulyar tipləri ayırd edilirdi. Hazırda morfoloji ələmətlərinə və görüntüləmə üsullarının nəticələrinə görə exinokokk kistlərinin 5 tipi ayırd edirlir:

I tip: incə divarlı olub, USM-də xitin qatı bariz görünmür, içərisində q1z qovucuqları yoxdur. Bu kistlərin USM görüntüsü bəsit kistlərə çox bənzəyir. Xitin qatını MRG ilə görmək olar.

II tip: kistin fibroz və xitin qatları USM,BT və MRG ilə görünür, q1z qovucuqları yoxdur.

III tip: multivezikulyar kistdir, içərisində qız qovucuqları mövcuddur. USMdə "arı pətəyi” şəklində görünür.

IV tip: parazitin ölməsi və ya partlaması nəticəsində xitin qatı qatlanır və USM də "yun yumağı" şəkilində görünür. Bu kistlər adətən ağırlaşmış- peritona, öd yollarına və diğər boşluqlara açılmış kistlərdir.

V tip: kistin divarında yerli və ya yayğın kalsifikasyonlar ortaya çıxır. Kalsifikasionun adətən ölü kistlərdə müşahidə edilməsinə baxmayaraq, residiv və canlı kistlərdə də görünə bilir.

Klinik gedişi. Exinokokk kistləri asimptomatik, simtomatik və ağırlaşmalı seyr edə bilirlər.

Erkən və kiçik kistlər dətən uzun müddət simptom vermirlər. Kist böyüyərək ətraf orqanlara təzyiq göstərdikdə klinik əlamətlər ortaya çıxır. Qarında kütlə, diskomfort, ağrı hissi, bə’zən sarılıq müşahidə edilir. Allergik tipli dəri səpgiləri də rast gəlir.

Ağırlaşmalar adətən kistin infeksiyalaşması və ya partlayaraq ətrafa yayılması nəticəsində meydana gəlir. Kist infeksiyalaşdıqda abses klinikası ortaya çıxır: atəş, ağnı, titrətmə, intoksikasiya. Kist partlamasının klinik əlamətləri açıldığı boşluqdan asılı olaraq dəyişir. Kistin öd yollarına açılması sarılıq, bə’zən də xolangit əlamətləri törədir. Periton boşluğuna açılan kistlərdə ağır anaflaktik reaksiya (hipotenziya, soyuq, göyərmiş dəri, qaşıntı və s.) və peritonit əlamətləri ortaya çıxır. Qaraciyər exinokokku plevraya, bronxlara və bağırsaqlara da açıla bilər. 
Nuru Yusifoğlu Bayramov. Qaraciyər rezeksiyast

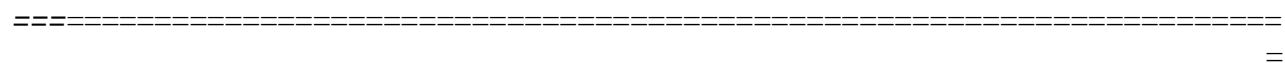

Diaqnostikası: Exinokokk kistinin diaqnostikasında üç əsas məsələ həll edilməlidir:

1. Kist exinokokk kistidirmi?

2. Exinokokk canlıdırmı?

3. Ağırlaşması varmı?

Görüntüləmə metodları exinokokk diaqnostikasında əsas yer tutur. Seroloji diaqnostika üsulları daha çox əməliyyatdan sonra residivin olubolmadığını aşkar etmək üçün istifadə edilir.

Xitin qatı va quz qovucuqlarının görünmasi exinokokk kistinin on vacib alamatidir.

USM və tomoqrafiya üsuları ilə ikiqatlı divar (fibroz və xitin qatlar), q1z qovucuqları ("arı pətəyi" əlaməti), qatlanmış xitin qatının ("yun yumağı" əlaməti) görünməsi exinokokk kistlərinin xarakteristik əlamətləridir. Qalın fibroz divar və kalsifikasionlar da exinokokk kistlərində daha çox rast gəlir. I tip kistlərdə fibroz qat incə olduğu və USM-də xitin qatı görünmədiyi üçün bunları bəsit kistlərdən ayırd etmək çətinlik törədir. USM və BT ilə müqayisdə MRG kistin daxili elementlərini daha yaxş1 göstərdiyi üçün bəsit və I tip kistlərin differensial diaqnostikasında istifadə edilir.

Omaliyyat vaxtı da kist içərisindo xitin qatı vo quz qovucuqlarının görünmasi exinokokk kistlari üçün patoqnomonikdir.

Kistin canlı olub-olmadığını müəyyən etmək həmişə mümkün olmur. Görüntüləmə üsulları ilə bütöv xitin qatının (ikiqatlı divar), q1z qovucuqlarının görünməsi kistin canlı olduğunu təsdiq edir. Xitin qatının parçalanması, yayğın kalsifikasionlar, irinləmə əlamətləri kistin ölü olduğunu göstərə bilir, lakin hər zaman dəqiq deyildir.

Oməliyyat vaxtı kist daxilində düşük təzyiqin olması (kist daxilində yüksək təzyiq canlı kistlər üçün xarakterikdir), xitin qatının parçalanması, bulanıq və irinli mayenin görünməsi adətən kistin ölü olduğunu göstərir.

Retroqrad xolangioqrafiya və ya kistə kontrast vurularaq öd yolları ilə əlaqəsinin olub-olmadığı dəqiqləşdirilir.

Oməliyyat vaxtı kistdə ödün tapılması onun öd yolları ilə əlaqəsini göstərir. Olaqəni dəqiqləşdirmək və yerini müəyyən etmək üçün kist boşluğu 
təmizlənib qurulandıqdan sonra qaraciyər zəif təzyiqlə sıxılır. Bu halda kistə açılan öd yollarından öd gəlməyə başlayır.

Müalicəsi. Exinokokkozun asas müalicəsi parazitin orqanizmdən kənarlaşdırılması və ya öldürülməsidir. Hazırda cərrahi üsul xəstəliyin asas müalicə metodudur. Parazitin öldürülməsi üçün antihelmintik və skolesidal dərmanlar istifadə edilir.

Hazırk1 antihelmintik dərmanların (mebendazol, albendazol) kist daxilindəki paraziti öldürə bilmədiyi göstərilir. Hesab edilir ki, kist içərisində yüksək təzyiq, xitin və fibroz qat dərmanın kist içərisinə keçməsinə mane olur. Antihelmintik dərmanlar hazırda əməliyyat vaxtı yayılmaları və residivi azaltmaq üçün istifadə edilir. Dərmanlar əməliyyatdan öncə 2-3 həftə, sonra isə, 4-6 həftə ərzində tə' yin edilir.

Son illər exinkokkun müalicəsi üçün daridən keçən kateterizasiya üsulu inkişaf etməyə başlamışdır. USM və ya BT altında kist boşluğuna kateter yerləşdirilir, maye çıxarılır, kontrast maddə vurulur. Kistin öd yolları ilə əlaqəsi yoxdursa boşluğa skolesidal maddələr vurulur və bir neçə gündən sonra kateter çıxarılır. Lakin bu üsul monovezikular və öd yolları ilə əlaqəsi olmayan kistlərdə aparıla bilər. Çünki multivezikulyar (III tip) kistlərdə q1z qovucuqlarını çıxarmaq olmur, skolesidal maddələr öd yollarında xolangit törədə bilir. Ona görə də, açıq və ya laparoskopik cərrahi üsul hazırda exinokokkun müalicəsində əsas yer tutur. Cərrahi müalicədə iki əsas prinsip var: paraziti atrafa yayılmadan çıxarmaq və qalan boşluğu ləğv etmək. Bu prinsiplərə uyğun müxtəlif üsullar mövcuddur.

Paraziti çıxarma (exinokokkektomiya) üsulları:

1. Evakuasiya - fibroz və xitin qatları açılır, kist möhtəviyyatı sorucu və ya "qaşıqla" çıxarılır. On çox istifadə edilən üsuldur, parazitin ətrafa yayılma ehtimalı yüksəkdir.

2. Enokulyasiya - fibroz qat açılır, xitin qatı bütövlükdə partlatmadan çıxarılır. Qaraciyərdə bu üsul az istifadə edilir, ağciyərdə isə istifadə imkanı yüksəkdir.

3. Perikistektomi - exinokokk fibroz qatla (perikist) birlikdə ətraf toxumadan ayrılıb çıxarılır. Az hallarda istifadə edilir.

4. Rezeksiya - qaraciyər sağlam toxuma səviyyəsində rezeksiya edilərək kist çıxarılır. On ideal üsul olmasına baxmayaraq, 
travmatikdir və yalnız periferik kistlərdə (divarının 1/3-dən azı qaraciyərlə təmasda olan kistlər) tətbiq edilməsi məqsədəuyğundur.

Qalıq boşluğu ləğv etmə üsulları:

1. Marsupalizasiya - kist divarını dəriyə tikərək boşluq bayıra açılır və qranulyasiya ilə dolması gözlənir. İnfeksiyalaşma riski yüksək və müalicə middəti uzun olduğu üçün hazırda istifadə edilmir.

2. Xarico drenaj - marsupalizasiyadan fərqli olaraq, kist xaricə drenaj vasitəsi ilə açılır. İrinləmiş kistlərdə istifadə olunur.

3. Omentoplastika - kist boşluğu böyük piyliklə doldurulur. On çox istifadə edilən üsuldur, xüsusən sərt, hərəkətsiz divarlı və mərkəzdə yerləşən kistlərdə çox faydalıdır. Lakin hər hansı bir səbəbdən (anadangəlmə, əvvəlki əməliyyatda istifadə edildikdə) piylik olmadiqda mümkün olmur.

4. Kapitonaj, intrafleksiyon - kist içəridən və ya bayırdan qatlanıb tikilərək boşluq bağlanır. Hərəkətli divarı olan kistlərdə və omentoplastika imkanı olmayan hallarda istifadə edilir.

Bu üsullardan hansinın seçilacəyi kistin tipindən, yerlaşməsindən, ă̆ırlaşmanın xarakterindən asılıdır (Sxema 3.4.). 
Qaraciyor rezeksiyasına göstorişlor va oks göstorişlor

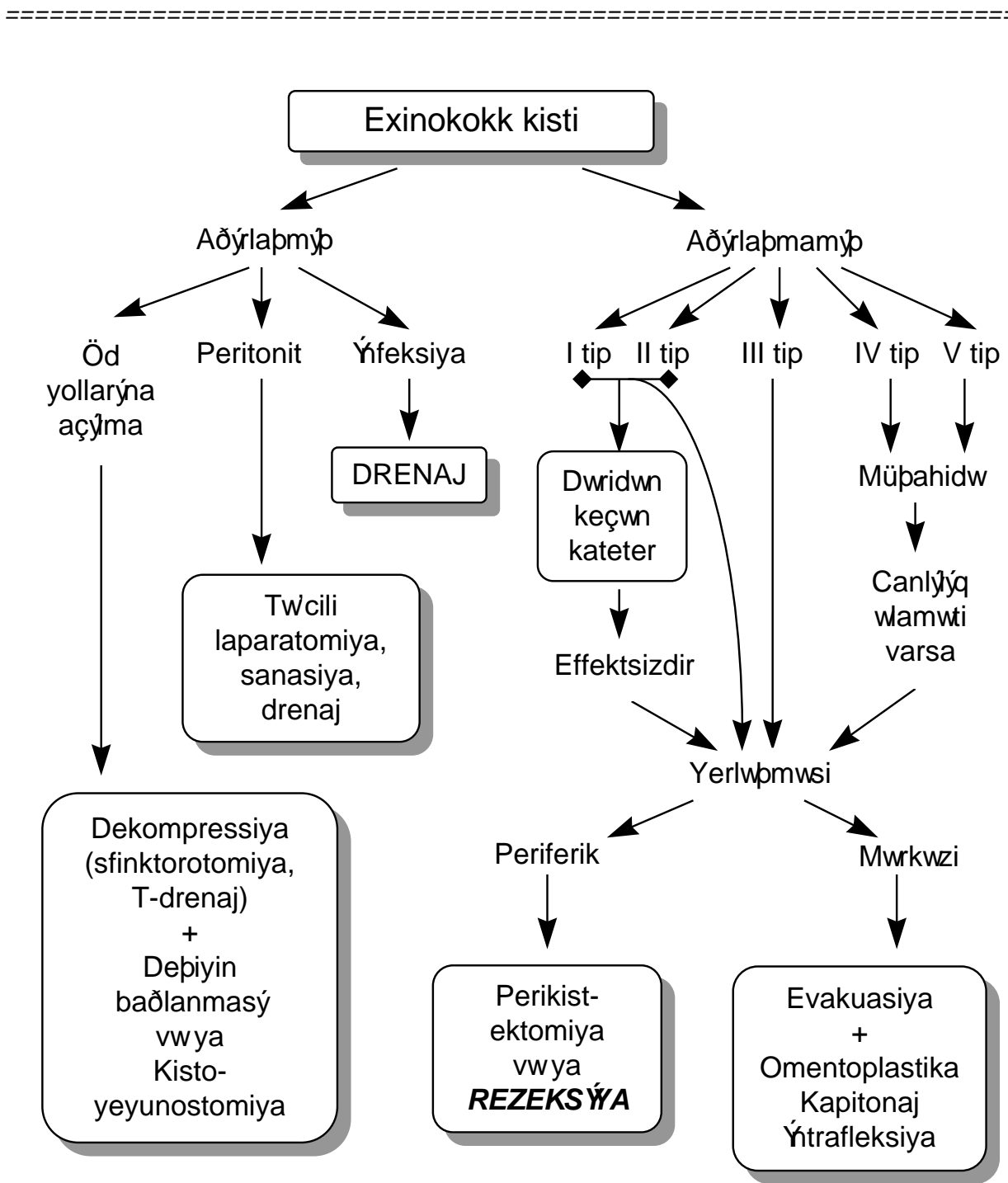

Sxema 3.4. Exinokokk kistindo müalico taktikası

\section{Alveolar exinokokk}


Echinococcus alveolaris paraziti tərəfindən törədildiyi hesab edilir. Parazitin əsas sahibinin tülkü və çaqqallar olduğu güman edilir. Xəstəlik nadirdir və Sibir və Alyaska bölgələrində müşahidə edilir.

Alveolokokkoz bir-birinə bitişik kiçik (mullimetrik) kistlərdən ibarət törəmə olub qaraciyər kapsulu üzrə yayılma və invaziya göstərir. Damarlara, parenximaya invaziya, residivləşmə xüsusiyyətinə görə bəd xassəli şişlərə çox bənzəyir. Klinik olaraq bu şişlərdən ayırd etmək çətindəir və adətən diaqnozu histoloji müayinədə qoyulur.

Müalicəsi cərrahi üsulladır. Erkən, damar və axacaqlara invaziya olmayan dövrdə sağlam toxuma səviyyəsində rezeksiyalar yaxşı nəticələr verir. Ekstrahepatik axacaqlara invaziya olduğu hallarda palliativ əməliyyatöd yollarının drenajı aparılır. Albendazolun uzun müddət istifadə edilməsinın xəstəliyin inkişafının qarşısını aldığı da bildirilir.

\section{QARACIYYR ABSESİ}

Abses qaraciyər toxumasinda nekroz, infeksion iltihab və septik əlamətlərlə xarakterizə olunan xəstəlikdir. Abseslər nadir hallarda rezeksiya tələb olunur.

Etiologiyası. Səbəbinə görə iki növü ayırd edilir:

1. Amöb absesi.

2. İrinli (piogenik) abses.

Amöb absesləri təkhüceyrəli trofozoid olan Entamebae histolitica tərəfindən törədilir və adətən amöb dizenteriyası keçirmiş xəstələrdə rast gəlir. Lakin, dizenteriya əlamətləri olmayan xəstələrdə də müşahidə edilir.

İrinli abses əksər hallarda qaraciyərdə və ya diğər orqanlardak1 xəstəliklərin ağırlaşması kimi ortaya çıxır. Absesə səbəb olan amillər qaraciyardo nekroz va ya patogen mikroorqanizmlarla yoluxma törədərək irinli infeksiyanın inkişafına şərait yaradırlar. Öd yolları xəstəlikləri, travma, arterial tromboz, pioflebit kimi amillər irinli abseslərin əmələ gəlməsində rol oynayırlar. İrinli abses kistlərin, bəd xassəli şişlərin, hətta amöb abseslərinin infeksiyalaşması nəticəsində də əmələ gələ bilir. İrinli abseslərdə ən çox $E$. coli va anaerob bakterioidlar rol oynayır.

Klinikası. Yüksək hərarət, üşütmə, qarında ağrı və intoksikasiya əlamətləri irinli abseslərdə rast gəlir. Zəif xəstələrdə və amöb abseslərində 
hərarət çox yüksəo olmur. Xəstələrdə plevral maye, assit, qarında şişkinlik, gərginlik əlamətləri də ortaya çıxa bilir.

Diaqnostikası. Yerli və ümumi sepsis əlamətləri ilə yanaşı USM və ya tomoqrafiyada qaraciyərdə abses boşluğun görünməsi abses diaqnozunu kəskinləşdirir. Kistlərdən fərqli olaraq abseslərin sərhədi kəskin olmur, möhtəviyyatının sıxlığı yüksək, hətta nekrotik toxumalar olarsa, heterogen görünür. Absesdə qaztörədən bakteriyalar olduqda və ya bağırsağa açılarsa içərisində qaz görünür.

Absesin amöb yoxsa, irinli olduğunu klinik əlamətlərə, antiamöb müalicəyə cavaba, seroloji reaksiyalara görə ayırd etmək mümkündür (Cədvəl 3.1.). Dəqiq diqnoz isə, ancaq absesin punksiyası nəticəsində mümkündür.

Cadval 3.1.

Qaraciyarin irinli va amöb abseslarinin differensial diaqnostikasl

\begin{tabular}{|c|c|c|}
\hline Olamat & Irinli abses & Amöb absesi \\
\hline Xəstənin vəziyyəti & A ğır, sepsis & Orta \\
\hline Ovvəlki xəstəlik & $\begin{array}{l}\text { Oksər hallarda öd yolları, qarın } \\
\text { boşluğunda iltihabi xəstəlik, travma }\end{array}$ & Dizenteriya \\
\hline $\begin{array}{l}\text { Ağciyər vo } \quad \text { plevrada } \\
\text { ağırlaşma }\end{array}$ & Plevro-pulmonal ağırlaşma nadir & $\begin{array}{l}\text { Plevro-pulmonal ağırlaşma } \\
\text { çox rast gəlir }\end{array}$ \\
\hline Yerləşməsi & Adətən mərkəzdə & Subkapsulyar \\
\hline Görüntüləmədə divarı & Barizdir & Divarı görünmür \\
\hline Serologiya & mənfidir & müsbətdir. \\
\hline Punktat & İrinli, bakteriyalarla zəngin & $\begin{array}{l}\text { Hemorragik, "şokalad } \\
\text { rəngli", trofozoidlər }\end{array}$ \\
\hline
\end{tabular}

Müalicəsi. Amöb absesləri əksər hallarda konservativ antiamöb müalicə ilə sağalırlar. İrinli abseslərin müalicəsi üçün isə drenaj şərtdir.

Amöb abseslərində 3-4 gün $750 \mathrm{mg} /$ gün dozda metronidazol verilir. Klinik əlamətlərdə yaxşılaşma müşahidə edilərsə bu müalicə 10 günə qədər davam etdirilir və sonra lüminal müalicə (yodokinol 20 gün + panamomisin 7 gün + diloxanid fomat 10 gün) aparılır. Ogər ilk 3-4 gün aparılan müalicəуə cavab alınmazsa drenaj edilməsi lazım gəlir.

İrinli abseslərdə antibiotikoterapiya və detoksikasiya başladılır, absesin sayına, lokalizasiyası və yanaşı xəstəliklərə görə drenaj üsulu seçilir 
(Sxema 3.5). Kiçik və çoxlu abseslərdə antibiotikoterapiyaya cavab alınarsa drenaja ehtiyac qalmır. Qarın boşluğunda əməliyyat tələb edən xəstəliklər olduqda, böyük və çoxlu abseslərdə, dəridən keçən drenaj yetərsiz olduqda abses boşluğu açıq və ya laparoskopik yolla drenaj edilir. Səthə yaxın, asan müdaxilə edilən abseslərdə USM və ya BT nəzarətində boşluğa dəridən kəçən kateter yerləşdirilərək drenaj tə'min edilir.

Az rast gəlsə də, bə'zi hallarda, xüsusən yetərli drenaj olunmayan hallarda abses xronik formaya keçir. Bu halda absesin sərt və hərəkətsiz fibroz divarı boşluğun sərbəst bağlanmasına imkan vermir. Qalıq boşluq isə, infeksiyanın davam etməsinə səbəb olur. Bundan başqa, irinli infeksiya ilə əlaqədar boşluğun plastikası da effektsiz olur. Belə hallarda qüsurlu dövranı ləğv etmək, xəstəni xronik infeksiyadan qurtarmaq üçün rezeksiya lazım gəlir.

Bir çox hallarda absesin etiologiyasını dəqiq bilmək mümkün olmur. Belə hallarda xəstənin vəziyyəti və klinik əlamətlərinə görə diaqnostik və müalicə taktikası seçilir.

\section{QARACIYOR KISTLORININ DIFFERENSIALL DİAQNOSTIKASI} VӘ REZEKSIYYAYA GÖSTəRIŞLəR

Göründüyü kimi qaraciyərdə xəstəliklər bir-birinə yaxın klinik (qaraciyərdə kütlə,ətrafa təzyiq) və görüntü (kist) əlamətləri ilə biruzə verirlər. Lakin, bunların təbiəti müxtəlif olduğu kimi, müalicəsi də fərqlidir. Ona görə də, kistlərin bir-birindən ayrılması, təbiətinin müəyyən edilməsi klinik praktikada vacib məsələlərdən biridir.. 
Qaraciyar rezeksiyasına göstorişlor va oks göstorişlor

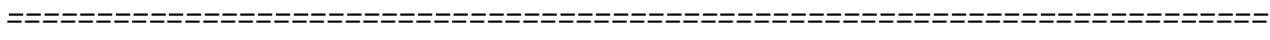

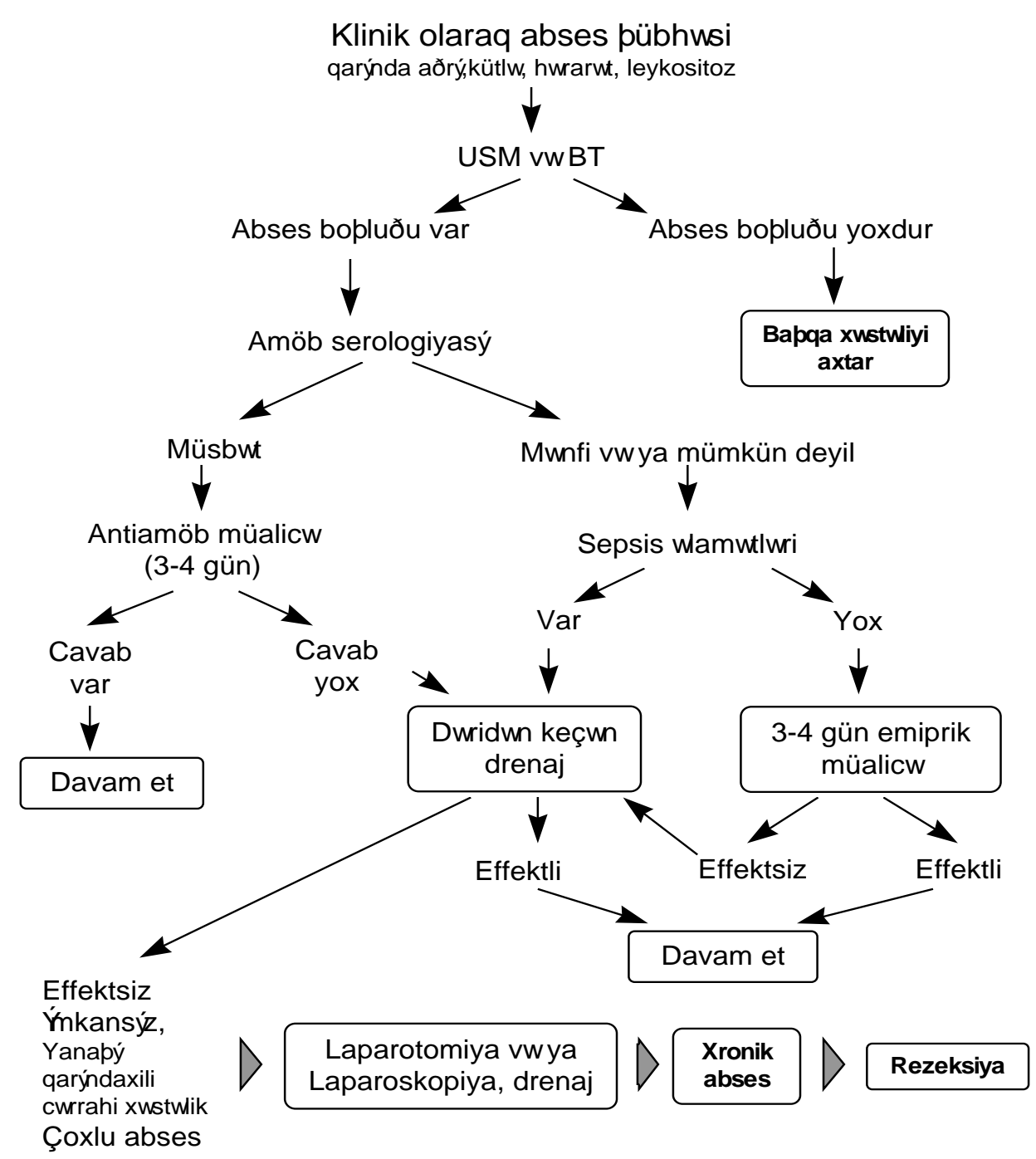

Sxema 3.5. Qaraciyor abseslorindo diaqnostika vo müalico taktikast

Kistlərin differensial diaqnostikasında başlıca kriteriyalar klinik əlamətlər və kistin daxili quruluşudur 
Yüksək hərarət, ağrıda artma, leykositoz kimi septik əlamətlər kistşəkilli törəmənin abses və ya absesləşmiş kist olduğunu göstərir. Absesdə əsas müalicə drenajdır.

Anadangəlmə, exinokokk, neoplastik kistlərin differensasiyasında kistin daxili quruluşunu ortaya çıxarmaq əsas yer tutur, çünki klinik əlamətlər çox bənzərdir.

İncə, düzgün divarın, möhtəviyyatın az sıxlıqlı və homogen olması anadangəlmə kistlər üçün xarakterikdir. Bu tipli kistin bir neçə ədəd olması və böyrəklərdə, sümüklərdə də müşahidə edilməsi polikistik xəstəliyi göstərir. Çoxlu, kiçik $(<5 \mathrm{sm})$ kistlər, xolangit əlamətləri Karoli xəstəliyinə şübhə yaradır. Xolangioqrafiyada intrahepatik öd yollarında kistşəkilli genişlənmələr diaqnozu dəqiqləşdirir.

Exinokokk kisti üçün ən səciyyəvi əlamət içərisində xitin qatı və/və ya qız qovucuqlarının görünməsidir. USM və tomoqrafiyalarda bunlar ikiqatl divar, "arı pətəyi", "yun yumağı" şəkilində görünür. İncə divarlı və xitin qatı USM vəuBT-də görünməyən kistlər (I tip) anadangəlmə kistlərə çox bənzəyir. Bunları ayırmaq üçün MRG daha yararlıdır, çünki, MRG-də kistin içərisi daha yaxşı göründüyü üçün incə xitin qatı ortaya çıxır.

Neoplastik kistlarda qalın, kaləkötür divar və divardan kist mənfəzinə doğru papillamatoz şəkildə uzanan şiş toxuması görünür. Birbirinə yaxın və möhtəviyyatlarındakı sıxlığının müxtəlif olması da neoplastik kistlər üçün xarakterikdir. Dəqiq diaqnoz patohistoloji müayinədə qoyulur.

Travmatik kistləri anadangəlmə kistlərdən gərqləndirmək çətindir. Anamnezdə travma və möhtəviyyat sıxlığının yüksək olması travmatik kistə şübhə yaradır. Dəqiq diaqnoz əməliyyatda içində öd və qan tapılması ilə və patoloji müayinədə divarında epitel qatının tapılmaması ilə qoyulur.

Klinik təcrübədə ən vacib məsələrdən biri də, budur ki, əgər qaraciyərdə kist tapılarsa nə edilməlidir? Kist əməliyyat vaxt1 tapılarsa punksiya edilir, divarın və möhtəviyyat xarakterinə baxılır, divar və möhtəviyyat patoloji müayinəyə göndərilir. Kist daxilində yüksək təzyiq, xitin qatı və qız qovucuqları exinokokku göstərir. 
Qaraciyar rezeksiyasına göstorişlor va oks göstorişlor

Kist simptomatik və ya asimtomatik xəstədə tapıldıqda klinik və görüntüləmə müayinələri aşağıdakı prinsiplərə əsaslanan ardıcıllıqla qiymətləndirilir:

\section{Kist tə'cili müdaxilə tələb edirmi?}

2. Kist mütləq əməliyyat edilməlidirmi?

Abses tə'cili müalicə tələb edir, neoplastik və exinokokk kistləri isə mütləq əməliyyat tələb edir.

Qaraciyər kistlərinə cərrahi nöqteyi-nəzərən baxd1qda kistşəkilli xastวliklardə qaraciyər rezeksiyasına göstarişlarin müəyyən edilməsidir. Ümumiyyətlə, kistlərin müalicəsi üçün aşağıdakı hallarda qaraciyər rezeksiyası tatbiq edilir:

1. Neoplastik kistlər, əgər ekstrahepatik yayılım yoxdursa.

2. Periferdə yerləşən exinokokk kistləri (divarının 1/3-dən azı qaraciyərlə təmasda olan kistlər).

3. Böyük damarlara və axacaqlara invaziya etməyən lokal alveolokokkoz.

4. Bir payı tutan simtomatik Karoli xəstəliyi.

5. Sərt, hərəkətsiz divarlı, xarici drenajla sağalmayan xronik abseslər. 


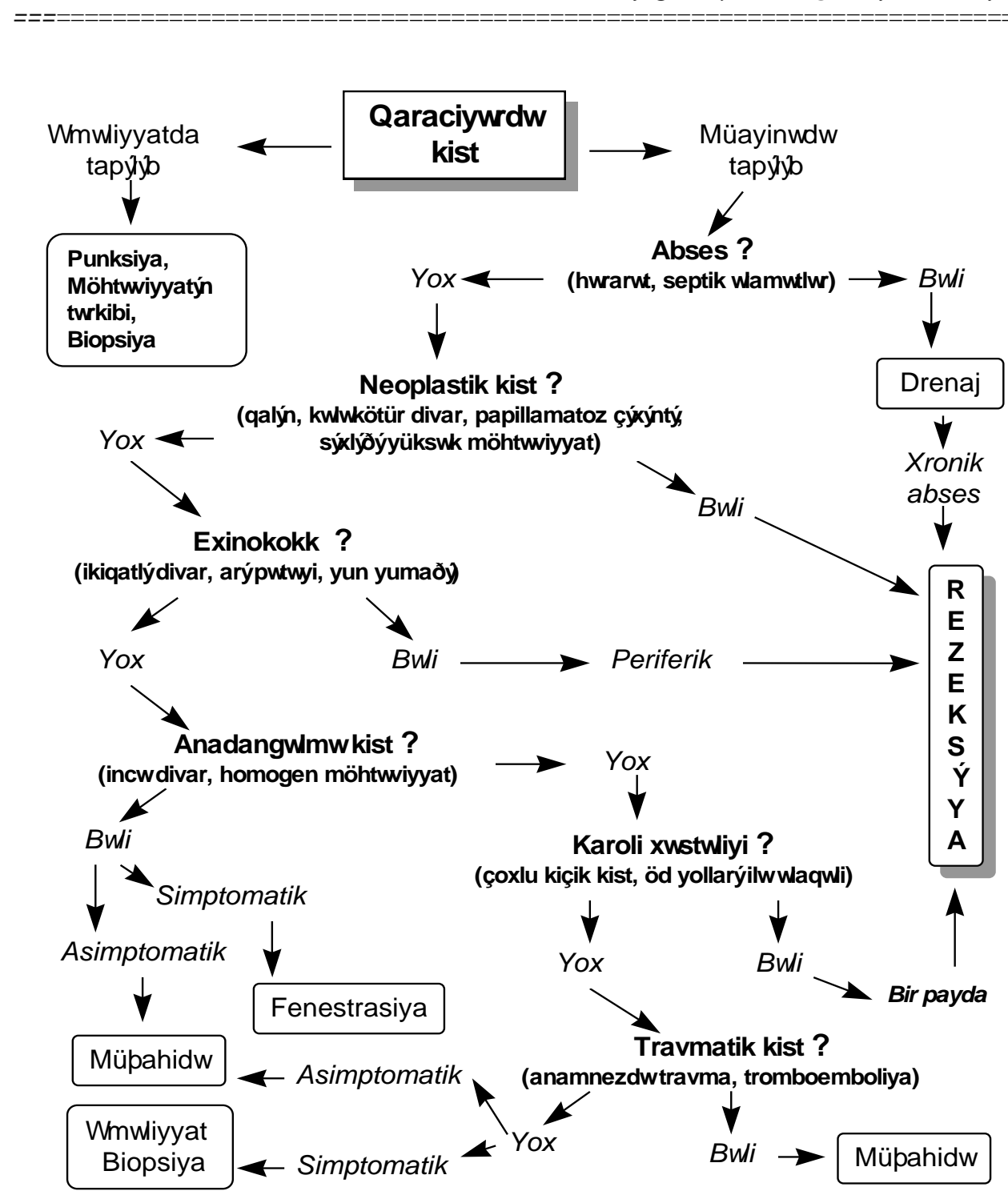

Sxema 3. 6. Qaraciyor kistlorindo differensial diaqnostika vo rezeksiyaya göstorişlar 
Qaraciyar rezeksiyasına göstorişlor va oks göstorişlor

\section{QARACIYYRİN BӘDXASSЭLI ŞişLəRİ}

Qaraciyər şişləri rezesiyaya ən çox göstəriş təşkil edən xəstəliklərdir. Ovvəlki bölümlərdə qeyd edildiyi kimi, qaraciyər toxumasından inkişaf dən birincili və metastaz nəticəsində əmələ gələn ikincili şişlərə rast gəlir. Birincili şişlər qaraciyərdəki bütün toxumalardan inkişaf edə bilir, lakin, hepatositlərdən, öd epitelindən və damarlardan inkişaf edən bəd və xoş xassəli şişlərə daha çox rast gəlinir.

Hemangioma qaraciyərin bəd və xoş xassəli şişləri arasında ən çox rast gələn xoş xassəli damar şişidir. Rast gəlmə tezliyinə görə ikinci yerdə metastatik şişlər durur. Metastatik şiş qaraciyərin birincili xərçəngindən 20 dəfə çox rast gəlir. Praktik olaraq qastrointestinal xərçənglərin hamısı və diğər orqanlardan inkişaf edən bəd xassəli şişlərin yarısından çoxu qaraciyərə metastaz verir. Üçüncü yerdə hepatosellular karsinoma, sonrakı yerlərdə isə, xolangiokarsinoma, hepatik adenoma, fokal nodulyar hiperplaziya durur. Diğər toxumalardan inkişaf edən birincili qaraciyər şişləri nadirdir. bəhs ediləcək.

Burada qaraciyərdə ən çox rast gələn birincili və metastatik şişlərdən

\section{HEPATOSELLULAR XəRÇӘNG}

Hepatosellular xərçəng (HSX) hepatositlərdən inkişaf edən, qaraciyərin ən çox rast gələn birincili bəd xassəli şişi olub, birincili xərçəngin $80 \%$-ni təşkil edir. Sənaye ölkələrində bütün şişlər arasında 0,2-0,8\%, bitki qidaları çox istifadə edilən ölkələrdə isə, 5,5-20\% hallarda rast gəlir. On çox 60-70 yaşlarında və kişilərdə (qadınlardan 2,5 dəfə çox) rast gəlir. Yüksək riskli ölkələrdə isə, daha çox 30-40 yaşlarında müşahidə edilir.

Etiologiyası dəqiq bilinmir. Lakin bir çox faktorların HSX inkişafındakı rolu dəqiqləşdirilmişdir:

Sirroz HSX əmələ gəlməsində rolu ən yüksək olan amil hesab edilir. HSX olan xəstələrin 60-90\%-ində sirroz tapılır. Postnekrotik (virus) sirrozu olan xəstələrin 40-50\%-ində, alkoqol sirrozunda isə 5\% hallarda HSX inkisaf edir.

Xronik B hepatiti olan xəstələrin 12\%-nə yaxınında HSX inkişaf edir. 
Karsinogenlor. Aflatoksinin, siderozis, oral kontraseptivlərin, torotrastın HSX inkişafinda rol uynadığı ehtimal dilir.

Anadangəlmə metabolik pozğunluqlar - $\alpha$-antitripsin defisiti, Oilson xəstəliyi, qalaktozemiya və s. HSK inkişafında rol oynayır. Hesab edilir ki, bu xəstəliklər sirroz törədərək HSX inkişafına şərait yaradir.

Böyümə tipinə görə HSX tək şiş (50\%), multisentrik kiçik (20\%) və mikroskopik diffuz şəkildə olur. HSX daha çox qapı venasına (25-40\%) və qaraciyər venalarına (16\%) invaziya edir, $8 \%$ hallarda isə uzaq metastazlar verir.

Histoloji cəhətdən HSX hepatositlərdən və stromadan ibarət olub, bə’zən kapsulu da olur. Xərçəngdəki hepatositlər görünüşünə görə normal hepatositlərdən çox fərqlənmir, lakin düzülüşünə görə trabekulyar, prevdoqlandulyar, kompakt, fibrolamellar və s. tipləri vardır.

Təsnifatı. HSX bir çox cəhətinə - şişin sitoloji tipi, diferensasiya dərəcəsi, ağırlaşmaları, yayılma dərəcəsinə görə təsnif edilə bilir. Hazırda ən çox istifadə edilən təsnifat şişin klinik-histoloji tipinə və yayılma dərəcəsinə görədir.

Klinik-histoloji cəhətdən fibrolamellar və adi tipli HSX ayrıd edilir. Fibrolamellar tip hepatositlarin sütunşəkilli düzülüşü, zəngin fibroz toxumanın - kapsulun, fibroz arakəsmələrin mərkəzində çapı̆̆ın və kalsifikasionların olması ilə xarakterizə olunur. Bu tip gənc yaşlarda (30-40 yaşlarda) çox rast gəlir, sirroz və diğər qaraciyər xəstəlikləri ilə əlaqəsi yoxdur. Şişdə $\alpha$-fetoprotein yüksəlmir, proqnozu adi tipə nəzərən daha yaxşıdır. Adi tip yaşlılarda, kişilərdə daha çox rast gəlir, sirroz və diğər qaraciyər xəstəlikləri ilə yaxın əlaqəsi var, $\alpha$-fetoprotein yüksəlir. Adi tipin histoloji cəhətdən müxtəlif növləri vardır: trabekulyar, psevdoqlandulyar, kompakt, skirroz və s.

Yayılma daracasina görə təsnifat Beynəlxalq TNM (tumor, nodul, metastaz) sisteminə əsaslanır. Şişin qaraciyərdə yayılma dərəcəsi "T" ilə, limfa düyünlərinə yayılması "N" ilə, metastazlar isə "M" ilə ifadə olunur. Şişin qaraciyərdə yayılma göstəriciləri kimi ölçüsü, sayı, böyük damarlara invaziyası və tutduğu payların sayı nəzərdə tutulur: 
$\mathrm{T}_{\mathrm{x}}$ - şiş müəyyən edilmir

$\mathrm{T}_{0}-$ şiş yoxdur

$\mathrm{T}_{1}$ - tək şiş, $<2 \mathrm{sm}$, damar invaziyası yoxdur

$\mathrm{T}_{2}$ - tək şiş, $<2 \mathrm{sm}$, damar invaziyası var tək şiş, $>2 \mathrm{sm}$, damar invaziyası yox

bir payda çoxlu şiş, $<2 \mathrm{sm}$, damar invaziyası yox

$\mathrm{T}_{3}$ - tək şiş $>2 \mathrm{sm}$, damar invaziyası var

bir payda çoxlu şiş, $<2 \mathrm{sm}$, damar invaziyası var

bir payda çoxlu şiş, $>2 \mathrm{sm}$, damar invaziyası var/yox

$\mathrm{T}_{4}$ - hər iki payı tutan çoxlu şiş

qapı venasına, qaraciyər venalarına, aşağı boş venaya invaziya edən şişlər.

$\mathrm{N}_{0}$ - regional limfa düyünləri tutulmayıb

$\mathrm{N}_{1}$ - regional limfa düyünləri tutulub

$\mathrm{M}_{0}$ - metastaz yoxdur

$\mathrm{M}_{0}$ - metastaz var

TNM mə'lumatlarına əsaslanaraq şişin yayılma dərəcəsini göstərən 4 mərhələ ayırd edilir:

I mərhəla: bir payda, tək, 2 sm-dən kiçik şiş, damar invaziyası, limfa düyünündə tutulma və metastaz yoxdur.

$\mathrm{T}_{1} \mathrm{~N}_{0} \mathrm{M}_{0}$

II mərhələ: bir payda, 2 sm-dən böyük tək və ya 2 sm-dən kiçik bir neçə şiş, damar invaziyası, limfa düyünündə tutulma və metastaz yoxdur.

$\mathrm{T}_{2} \mathrm{~N}_{0} \mathrm{M}_{0}$

III mərhələ: bir payda yerləşmiş şiş, damar invaziyası və ya limfa düyünündə tutulma var, metastaz yoxdur.

$\mathrm{T}_{3} \mathrm{~N}_{0} \mathrm{M}_{0}, \mathrm{~T}_{1-3} \mathrm{~N}_{1} \mathrm{M}_{0}$ 
IV mərhələ: şiş hər iki paydadır və ya uzaq metastaz İstənilən $\mathrm{N}$ və $\mathrm{M}$-də $\mathrm{T}_{4}$ və ya istənilən $\mathrm{T}$ və $\mathrm{N}-\mathrm{d} ə \mathrm{M}_{1}$

Praktik təcrübədə daha asan olan aşağıdakı təsnifat istifadə edilə bilər:

I mərhələ: bir payda tək şiş var, damar invaziyası, limfa düyünündə tutulma və metastaz yoxdur.

II mərhələ: bir payda bir neçə şiş var, damar invaziyası, limfa düyündə tutulma və metastaz yoxdur.

III morhələ: bir payda yerləşən şiş intrahepatik damarlara invaziya etmiş və ya yerli limfa düyününə yayılmışdır, metastaz yoxdur.

IV mərhələ: şiş hər iki paydadır və ya ekstrahepatik damarlara invaziya var və ya uzaq metastaz var

HSX-in mərhələlərə ayrılması həm müalicə üsulunun seçilməsində həm də müalicənin nəticələrinin və proqnozun qiymətləndirilməsində əhəmiyyətlidir. I və II mərhələdəki şişlərdə rezeksiya edilir. III mərhələdəki şişlərdə də rezeksiya edilə bilir, lakin nəticələri əvvəlkilərə nəzərən qənaətbəxş deyildir. IV dövrdə rezeksiya əks göstərişdir.

Klinikası. HSX adətən qeri-spesifik əlamətlərlə ortaya çıxır. Qarının sağ tərəfində ağrı,zəif sarılıq, arıqlama, iştahsızlıq ən çox rast gələn əlamətlərdir. Şiş hüceyrələrinin atipik funksiyası ilə əlaqədar paraneoplastik sindromlar - karsinoid sindrom, ginekomastiya, eritroblastoz və s. rast gələ bilir. Obyektiv müayinədə hepatomeqaliya, sarılıq, assit müşahidə edilə bilir.

Diaqnostikası. Görüntüləmə üsulları, şiş markerləri ( $\alpha$-fetoprotein) və biopsiya diaqnostikada əsas yer tutur.

USM-də HSX toxumalı törəmə şəklində, hiperekoik (15\%), hipoekoik (25\%) və qarışıq (60\%) görünür. Kalsifikasionlar şişdə nekrozu göstərir və fibrolamellar tipdə daha çox rast gəlir. USM-in həssaslığ $190 \%$, spesifikliyi 60-70\%-dir. 1 sm-dən kiçik və səthi şişlərdə USM-in həssaslığ və spesifikliyi azalır.

KT-də hipodens, az hallarda isə izo-, hiperdens kütlə müəyyən edilir. Şişdə nekroz, fibroz və kalsifikasyonlar olarsa heterogen görünür. 
USM-də olduğu kimi KT-nin də 1 sm-dən kiçik və səthi şişlərdə həssaslığı çox azdır. Kontrastlı KT-də HSX adətən hiperdens (hipervaskular) görünür. Ethiodol kontrastı ilə çəkilən gecikdirlilmiş KT-də hiperdens şəkildə görünür və 0,5 sm-dən böyük törəmələr görünə bilir. $\mathrm{Bu}$ üsulun dəqiqliyi daha yüksəkdir (80\%-ə yaxın).

MRT-də xərçəng T1-də hipointens, T2-də isə hiperintens görünür. MRT yağ toxumasını və sirrotik qaraciyəri KT-yə görə daha yaxşı göstərdiyi üçün HSX-i sirrotik düyündən, yağ toxumasından və hemangiomadan ayırmağa imkan verir.

Angioqrafiyada hipervaskular törəmə və damar invaziyası görünür. Doppler USM törəmənin qan təhcizatının çox olduğunu və böyük damarlara invaziyanı göstərə bilir.

Laborator müayinələrdən ən spesifiyi $\alpha$-fetoproteinin artmasıdır. Lakin fibrolamellar tipdə $\alpha$-fetoprotein artmır. Diğər laborator göstəricilərdəki dəyişiklik qeyri-spesifikdir. Bilirubin, transaminaz səviyyəsində artma, paraneoplastik sindrom əlamətlərihiperxolesterinemiya, eritrositoz, hipoqlisemiya, hiperkalsemiya müşahidə edilə bilər.

Beləliklə, HSX-in əsas diaqnostik simptomları:

USM: qarışıq törəmə, az hallarda hipo- və hiperekoik törəmə

KT: kontrastsızda- hipodens, kontrastlıda is Hemangiomalardan ayırmaq üçün dinamik KT

MRT: T1-də hipointens, T2-də hiperintens. Hemangiomları və sirrotik düyünləri ayırmaq üçün T2 və ya kontrastlı MRT

$\alpha$-fetoprotein səviyyəsində yüksəlmə

Lakin, bu əlamətlərin heç biri HSX üçün patoqnomonik və çox dəqiq deyildir. Ona görə də şübhəli hallarda iynə biopsiyası və ya laparoskopik biopsiya aparılması məsləhətdir.

Müalicəsi. Diğər bəd xassəli şişlərdə olduğu kimi HSX müalicəsində də əsas prinsip şiş toxumasının aradan qaldırılmasıdır. Hazırda bunun üçün müxtəlif üsullar tətbiq edilməkdədir - rezeksiya, kriodestruksiya, lazerodestruksiya, mikrodalğalarla destruksiya, etanolla destruksiya, intraarterial və intraportal kimyaembolizasiya və s. Qaraciyər rezeksiyası 
HSX-in asas müalicə üsuludur, diğərlari isə, aməliyyatönü dövrdo şişi kiçiltmək və ya əməliyyatdan sonra residivi azaltmaq üçün köməkçi üsul kimi istifado olunur.

Lakin rezeksiya I və II mərhələdəki şişlərdə, yə’ni bir payda yerləşən böyük damarlara invaziya etməyən və uzaq metastazları olmayan şişlərdə aparıla bilir. HSX-i bu mərhələlərdə, yə’ni rezektabel dövrdə aşkar etmək çətindir. Diaqnoz qoyulduqda rezeksiya imkanı fibrolamellar xərçəngdə 48\%, adi tipdə isə $17-23 \%$ təşkil edir. Rezeksiyadan sonra 5 illik yaşama adi tipdə $30 \%$, fibrolamellar tipdə isə $60 \%$-dir.

III mərhələdə rezeksiya edilə bilir, ancaq nəticələri qənaətbəxş deyil. Bu dövrdə damar invaziyası və limfa düyünlərində tutulma olduğu üçün şişin retroqrad yayılması və multisentrik ehtimalı yüksəokdir.

IV dövrdə rezeksiya əks göstərişdir. Böyük damarlara invaziya, hər iki payı tutma və ya uzaq metastazlar olduğu üçün rezeksiya texniki cəhətdən mümkün olmur və ya faydasız olur. Bu qrup xəstələrdə yerli və ya sistemik kimyaterapiya aparılır.

Son illər uzaq metastazı olmayan qeyri-rezektabl şişlərdə şişi kiçiltmək və ya böyümə sür'ətini azaltmaq məqsədi ilə intraarterial və ya intraportal kimyaembolizasiya tətbiq edilir.Bu müalicədən 1-2 ay sonra şiş kiçilib rezektabel vəziyyətə gələrsə, rezeksiya edilir. Effekt zəif olarsa, müalicə təkrar edilə bilər.

Proqnozu qənaətbəxş deyildir. Diaqnoz qoyulduqdan sonra müalicə olunmayan halda orta yaşama müddəti adi tipdə 4-6 ay, fibrolamellar tipdə isə 30-32 aydır. Rezeksiyadan sonra 5 illik yaşama adi tipdə $30 \%$, fibrolamellar tipdə isə $60 \%$-dir.

\section{XOLANGIOKARSINOMA}

Xolangiokarsinoma öd axacaqları epitelindən inkişaf edən bəd xassəli şişdir. İnkişaf etdiyi yerə görə intrahepatik və ekstrahepatik (xoledox xərçəngi) növləri vardır. İntrahepatik xolangiokarsinoma qaraciyərin birincili bəd xassəli şişləri arasında hepatosellular xərçəngdən sonra ikinci yerdə durur. 
Qaraciyar rezeksiyasına göstorişlor va oks göstorişlor

Xolangiokarsinomanın etiologiyası tam mə'lum deyildir. Tez-tez təkrarlayan xolangitlərin və xoledox kistlərinin risk faktoru olduğu ehtimal edilir.

Morfoloji cəhətdən xolangiokarsinomanın düyünlü və diffuz tipi ayırd edilir. Xərçəng ən çox axacaq üzrə yayılır, qaraciyər parenximasına və damarlara invaziya edir. Limfa düyünlərini tutma və uzaq metastazlar da az rast gəlmir. İntrahepatik xolangiokarsinomanı yayılması hepatosellular xərçəngə çox bənzəyir. Ekstrahepatik xolangiokarsinoma isə daha çox axacaq böyunca yayılır, qapı venasına, I və IV seqmentlərə invaziya edir.

Xəstəliyin patofiziologiyasında $\ddot{o d}$ axacaqlarının obliterasiyası və damarlara invaziya əsas patogenetik faktordur. Ekstrahepatik xolangiokarsinomada böyük axacaq tutulduğu üçün total xolestaz və sarılıq daha çox rast gəlir. İntrahepatik xolangiokarsinomada isə, xolestaz qaraciyərin bir bölgəsində baş verir, sarılıq isə müşahidə olunmaya bilir.

Xolangiokarsinoma ilk dövrlərdə zəif əlamətlərlə biruzə edir. Qarında ağrı, kütlə hissi, arıqlama gec mərhələlərdə ortaya çıxır. Sarılıq və diğər xolestaz əlamətləri ekstrahepatik formada erkən mərhələdə, intrahepatik formada isə, gec mərhələdə ortaya çıxır.

USM-də genişlənmiş intrahepatik öd yolları və hiperekoik törəmə görünür. İntrahepatik xolangiokarsinomada öd yollarında genişlənmə bir bölgədə, ekstrahepatik xərçəngdə isə, hər iki payda müşahidə edilir. Hər iki halda da distal öd yollarında genişlənmə olmur. Strikturlardan fərqli olaraq xərçəngdə damar invaziyası doppler USM ilə görünə bilir.

KT-də homogen, hipodens və irregulyar kənarlı törəmə görünür. Angioqrafiyada damar invaziyası görünə bilir. Xolangioqrafiya öd yollarındakı darlığın yerini və dərəcəsini dəqiqliklə göstərir. MRT-nin yeni metodları olan kontrastsız işıltılı xolangioqrafiya öd yolları patologiyasını daha aydın görməyə imkan verir.

Laborator göstəricilər qeyri-spesifikdir və əsasən xolestaz əlamətləri ortaya çıxır. Ümumi xolestaz baş verdiyi hallarda bilirubinlə yanaşı QF və QQT artır, yerli xolestasda isə QF və QQT artmasına baxmayaraq bilirubin səviyyəsi normal olur. 
Beləliklə, öd yollarının genişlənməsi, tam və yerli xolestaz göstəriciləri ilə birlikdə qaraciyərdə və qap1 bölgəsində törəmə göründüyü hallarda xolangiokarsinoma ehtimalı yüksəkdir.

Xolangiokarsinomanın radikal müalicəsi carrahi üsuldur. İntrahepatik xolangiokarsinomada əməliyyata göstəriş və əks göstərişlər hepatosellular xərçəngdə olduğu kimidir. Görüntüləmə üsulları ilə bu iki patologiyanı bir-birindən ayırmaq çətindir və diaqnoz adətən patohistoloji müayinə ilə qoyulur.

Ekstrahepatik xolangiokarsinomanın mülacəsinda asas prinsipi: rezektabel hallarda rezeksiya, qeyri-rezektabel hallardai isə xolestazın qarşısını almaq üçün palliativ müdaxilə- daxili öd drenaj1. Müalicə taktikasını müəyyən edən amillər xərçəngin axacağa, damar və parenximya invaziya daracasi, uzaq metastazlar va xəstanin ümumi vaziyyatidir (Şəkil 3.7).

Qeyri-rezektabel hallarda- uzaq metastazlar, limfa düyününə yayılma, orqan və sistem yetməzliyi olan xəstələrdə daxili öd drenj1 tətbiq edilir. Bunun üçün bilio-enterik anastomozlar (III seqment axacağı, qaraciyər axacağı və ya diğər qaraciyərdaxili öd axacaqları ilə nazik bağırsaq arasında anastomoz), tunelizasiya üsulları istifadə edilir. Bu xəstələrdə əməliyyat edərək və ya endoskopik yolla axacaqlara stend qoymaq olar.

Damara invaziya olduqda rekonstruksiya imkanları nəzərə alınır. Rekonstruksiya imkanı varsa, qaraciyərin damarı ən çox tutulan payı rezeksiya edilir, qalan payın arteriya vo venası rekonstruksiya edilir. Rekonstruksiya imkanı olmayan hallarda palliativ əməliyyat- daxili drenaj edilir.

Damar invaziyası olmayan hallarda xəstəliyin rezeksiya olma ehtimalı yüksəkdir. $\mathrm{Bu}$ halda xərçəngin qaraciyərdaxili axacağa və parenximaya yayılma dərəcəsinə görə hərəkət edilir. Axacağı tam tutulan payın şişlə birlikdə rezeksiya edilməsi lazım gəlir. Axacaq tam tutulmadıqda isə parenximaya invaziyası nəzərə alınr və invaziya görünən seqment şişlə birlikdə ç1xarılaraq hepatiko-yeyunostomiya qoyulur. Xolangiokarsinoma ən çox I və IV seqmentlərə invaziya etdiyi üçün bu seqmentlərin çıxarılması lazım gəlir. 
Qaraciyar rezeksiyasına göstorişlor va oks göstorişlor

Parenximaya invaziya etməyən xoledox səviyyəsindəki şişlərdə axacaq sağlam toxuma səviyyəsində rezeksiya edilərək hepatikoyeyunostomiya qoyulur.

Beləliklə, xolangiokarsinoma aşağıdakı hallarda rezeksiyaya göstəriş sayılır:

1. Rezektabel intrahepatik xolangiokarsinoma: uzaq metastaz, böyük damarlara invaziya və hər iki paya yayılma yoxdur.

2. Parenximaya, intrahepatik axacaqlara, damarlara invaziya edən ekstrahepatik şişlərdə, əgər rekonstruksiya imkanı varsa, uzaq metastaz və limfa düyünlərinə yayılma yoxdur.

\section{METASTATIK QARACIYYR ŞIŞLӘRİ}

Qaraciyər orqanizmdə limfa düyünlərindən sonra ən çox metastaz olan orqandır. Metastatik şişlər qaraciyərin birincili bəd xassəli şişlərindən 20 dəfə çox rast gəlir. Mə’də-bağırsaq şişlərinin hamısı, diğər şişlərin yarısından çoxu qaraciyərə metastaz verir. 


\section{Ekstrahepatik xolangiokarsinoma}

$\downarrow$

Limfa düyününwyayŷma, uzaq metastaz, orqan vwsistem yetmwzliklwri

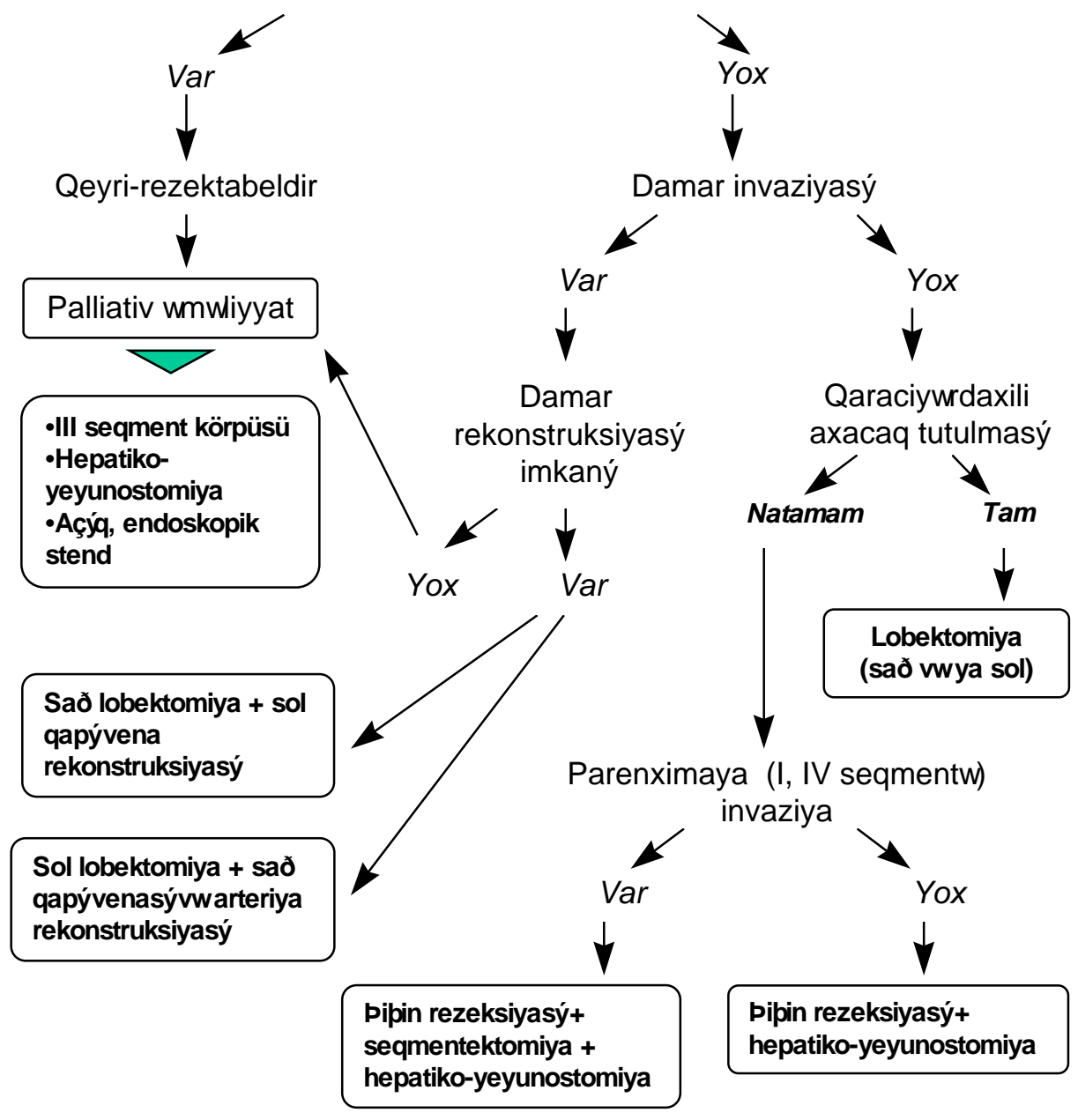

Şəkil 3.7. Ekstrahepatik xolangiokarsinomada müalicə taktikası 
Qaraciyar rezeksiyasına göstorişlor va oks göstorişlor

Qaraciyərdə ən çox rast gələn metastatik şişlər çənbər bağırsaq (42\%), mə’də (23\%), mə’dəaltı vəzi (21\%), süd vəzi (14\%), ağciyər $(13 \%)$ xərçəngidir.

Metastatik şişlər əksər hallarda (98\%) multipl olub, hər iki payı (77\%) tutar. Să̆ pay (20\%), sola (3\%) nəzərən daha çox tutulur.

Qaraciyərə metastaz arterial qanla, qapı venası, birbaşa təmasla, və limfatik yolla retroqrad yolla yayılır. On çox yayılma yolu arterial qanla və qap1 venas1 vasitəsi ilə olur.

Metastatik şişlər şiş hüceyrələrindən və stromadan ibarət olub, ölçüləri böyüdükcə nekroz bölgələri ortaya çıxır. Şiş ətrafındakı normal qaraciyər toxumasında iltiabi reaksiya müşahidə edilir. Metastatik şişlərdə müxtəlif sıxlıqlı toxumaların olması, onların heterogen görünməsinə səbəb olur.

Metastatik şiş hüceyrələri normal qaraciyər hüceyrələrindən morfofunksional cəhətdən fərqlənirlər. Bu fərq rəngə və görüntüləmə əlamətlərinə də sirayət edir. Metastazlar, xüsusən də adenokarsinomalar ağ rəngdə olub, normal qaraciyərə nəzərən daha sərtdirlər və tərkibindəki fibroz toxumanın miqdarından asılı olaraq sərtlikləri arta bilər.

Stroma şişin qidalanma və dayağını tə'min edən damar və birləşdirici toxumadan təşkil olunmuşdur. Metastatik şişlər qidalanmasını başlica olaraq arterial qandan alırlar. Bu xüsusiyyətləri arterioqrafiyada və intraarterial kimyaterapiyada nəzərə alınır.

Nekroz şişin böyüməsi ilə əlaqədar şişin mərkəzində və ya qanaxmalar nəticəsində qidalanma pozulmasına bağlı olaraq meydana gəlir. Nekroz şiş daxilində fibrotik toxuma və kalsifikasionlar əmələ gəlməsinə səbəb olur. Mərkəzində nekrozun olması səthdə yerləşən şişlərə xarakteristik "nəlbəki" şəkli verir.

Şişlər normal qaraciyər toxumasında reaktiv iltihabi reaksiya (perihepatit) və venoz staz törədir ki, bu da ödematoz bir halqa əmələ gəlməsinə səbəb olur. Ödemli halqa USM və MRT ilə aydın görünə bilir.

Şişlər qaraciyər venasına, qapı venasına, aşağı boş venaya və öd yollarına invaziya etdikdə portal hipertenziya, aşağı boş vena sindromu və mexaniki sarılıq törədirlər. 
Qaraciyərin metastatik şişlərindəki klinik əlamətlər şişin böyüməsi ilo slaqadar tozyiq, invaziya noticosindo qaraciyərin, magistral damarların vo axacaqların funksional pozulmaları noticosindo ortaya çıxır. Hepatomeqaliya və qaraciyər enzimlərində artma ən çox rast gələn kliniklaborator əlamətlərdir. Qələvi fozfataza $(\mathrm{QF})$ və laktat dehidrogenaza $(\mathrm{LDH})$ enzimlərinin artması metastatik şişlərdə çox rast gəlir. QF-nin artmasını şiş hüceyrəsində aktiv proliferasiya və periferik öd yolları tıxanması ilə izah etmək olar. Şiş toxumasında çox rast gələn anaerob metabolizm və nekroz LDH-1n artma səbəbi hesab edilə bilər. ALT və AST səviyyələrində artmaya da rast gəlir. Bilirubin səviyyəsində artma şişin magistral öd yollarını tıxadığını, albumin səviyyəsində azalma isə şişin qaraciyərin böyük hissəsini invaziya etdiyini göstərir. Qeyd etmək lazımdır ki, metastatik şişlər sirrotik xəstələrdə rast galmədiyi üçün, qaraciyər funksional göstəricilarində izah olunmayan dəyişiklik müşahida edilon xastələrdo metastaz ehtimalını unutmamaq lazımdır.

Portal hipertenziya əlamətləri, aşağ 1 boş vena sindromunun müşahidə edilməsi şişin böyük damarları tutduğunu göstərir.

Diaqnostikası. Klinik əlamətlərlə yanaşı görüntüləmə, patohistoloji üsullar diaqnostikada mühüm yer tutur.

USM qaraciyər şişlərinin müəyyən edilməsində həssas üsullardan biridir. Dərində yerləşən və ölçüsü $1 \mathrm{sm}$-dən böyük olan törəmələrin aşkar edilməsində həssaslığı yüksək olduğu halda (88-90\%), səthi və 1 sm-dən kiçik şişlərin müəyyən edilməsində bu göstərici çox (25\%) kiçikdir. USM də kiçik metastatik şişlər adətən hipoekoik görünürlər, nekroz, fibroz və kalsifikasiyanın olması heterogen göstüntüyə səbəb olur. Şiş ətrafındakı ödemli halqa hipoekoik şəkildə görünür ki, bu da metastatik şişlər üçün çox xarakterikdir. Ümumiyyətlə, USM-nin metastatik şişlər üçün spesifikliyi 60$70 \%$ həddindədir.

Kontrastsız KT-də metastatik şişlər hipoekoik və ya heterogen görünürlər. Kontrastlı müayinələrdə hiperdens görüntü hipervaskulariteni göstərir. Metastatik şişlərin tə’yin edilməsində iodin kontrastlı gecikdirilmiş KT və KT-angioqrafi (arterio ve ya arterio-portoqrafi) üsulları daha yararlıdır. İodin verilmesindən 4-6 saat sonra çəkilən tomoqrammalarda kontrastın qalması bəd xassəli şişin olduğunu göstərir. KT-angioqrafiya 
Qaraciyar rezeksiyasına göstorişlor vo əks göstorişlor

qaraciyər arteriyasına (arterioqrafiya) və ya yuxarı müsariqə arteriyasına (arterial portoqrafiya) kontrast verilərək çəkilir.KT qaraciyərdə $1 \mathrm{sm-dən}$ böyük və dərində yerləşən şiş törəmələrinin $60-70 \%$ həssaslıqla, bundan kiçik və səthi şişləri $10-20 \%$ həssaslıqla göstərir. KT-ilə metastatik şişləri birincili şişlərdən ayırmaq çətindir. Dinamik KT metastatik şişlərin hemangiomalardan ayrılması, KT-angioqrafi isə qaraciyərdə əlavə metastazların olub-olmamasını müəyyən etmək üçün istifadə edilir.

MRT ilə daha kiçik (<1 sm)şișləri və metastatik şişlərin xarakteristik əlaməti olan ödemli halqanı görmək mümkündür. Bundan başqa MRT şişin daxili quruluşunu daha aydın göstərir. Hüceyrospesifik kontrastlı MRT üsulunun klinik praktikaya totbiqi metastatik şişlorin differensial diaqnostikasında mühüm bir addım olacaqdır.

Radioizotop müayinə 1,5-2 sm-dən böyük şişlərin aşkar edilməsində yüksək həssaslıq göstərir (80-90\%).

Biopsiya şişin tabiatini göstarən an güvanli üsuldur. Biopsiya görüntüləmə üsullarının köməyi ilə aparıldıqda daha dəqiq nəticə verir.

Klinik praktikada üç ənənəvi diaqnostik məsələ (varmı? nədir? nə qədərdir?) metastatik şişlərin diaqnostikasında aşağıdakı şəkildə qarşıya çı1xır:

Vücudun har hansı bir yerinda bad xassali şişi oln xəstado qaraciyarda metastaz varmı?

Qaraciyərdə tapılan törəmə metastatik, yoxsa birincili şişdir?

Rezektabel metastatik şişi olan xastado qaraciyərin diğar bölgasinda alava metastazlar varmı?

Xərçəngi olan xəstələrdə, xüsusən də mə'də-bağırsaq xərçəngində qaraciyəri müayinə etmək mütləq lazımdır. Bu xəstəliyin dövrünü və müalicə taktikasını müəyyən etməyə imkan verir. Qaraciyərin fiziki müayinəsi ilə yanaşı funksional və görüntüləmə üsulları da tətbiq edilməlidir. ALP və LDH əksər hallarda ALT və AST isə bə'zi hallarda yüksəlir. Qaraciyər enzimləri normal olan xəstələrdə qaraciyərdə metastaz ehtimalı xeyli azalır $(90 \%)$. Lakin bu hər zaman yetərli olmur və görüntüləmə üsullarından ən az biri ilə müayinə aparmaq lazımdır. USM həssas və ucuz olduğu üçün daha çox istifado edilir. 
Qeyd etmək lazımdır ki, yerli yayılma dəracəsindən asılı olmayaraq, qaraciyərə metastaz verma ehtimal yüksək va carrahi aməliyyat planlanan şişlardə qaraciyər funksional va görüntülamo üsulları ila mütlaq müayinə edilmalidir (Şəkil 3.8). Misal olaraq, yoğun bağırsağın rezektabel xərçəngində $29 \%$ hallarda qaraciyərdə metastaz tapılır.

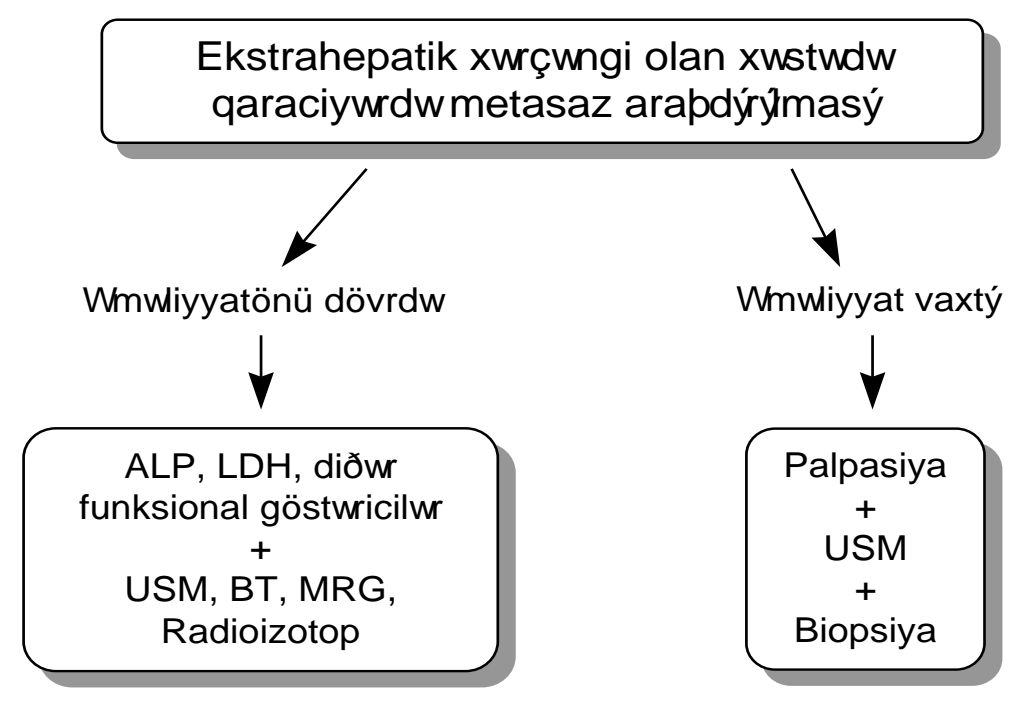

Şəkil 3.8. Ekstrahepatik xərçəngi olan xəstəlardə qaraciyər müayinəsi

Íkinci məsəla- qaraciyərdəki törəmənin metastatik şiş olubolmamasının müəyyən etmək klinik praktikada ən çətin məsələdir. Çünki, bir tərəfdə metastatik şişlər müxtəlif mənşəlidirlər, spesifik əlamətləri yoxdur, digər tərəfdən müasir görüntüləmə üsulları şişin hüceyrəvi tərkibini göstərə bilmir. Ona görə də, xəstələrdə klinik, laborator və görüntüləmə müayinələrinin nəticələrini birlikdə qiymətləndirmək lazımdır (Şəkil. 3. 9). Sirrotik qaraciyərdə metastatik şişlərin görünmədiyini, USM və MRT-də şiş ətrafında "ödemli halqa" əlaməti, mə'də-bağırsaq şikayətləri, anamnezdə hər hansı bir orqanda bəd xassəli şiş mə'lumatı nəzərə alınmalıdır. Bütün bu müayinalar natica vermadikda USM altında iyna biopsiyası etmak lazımdır. 


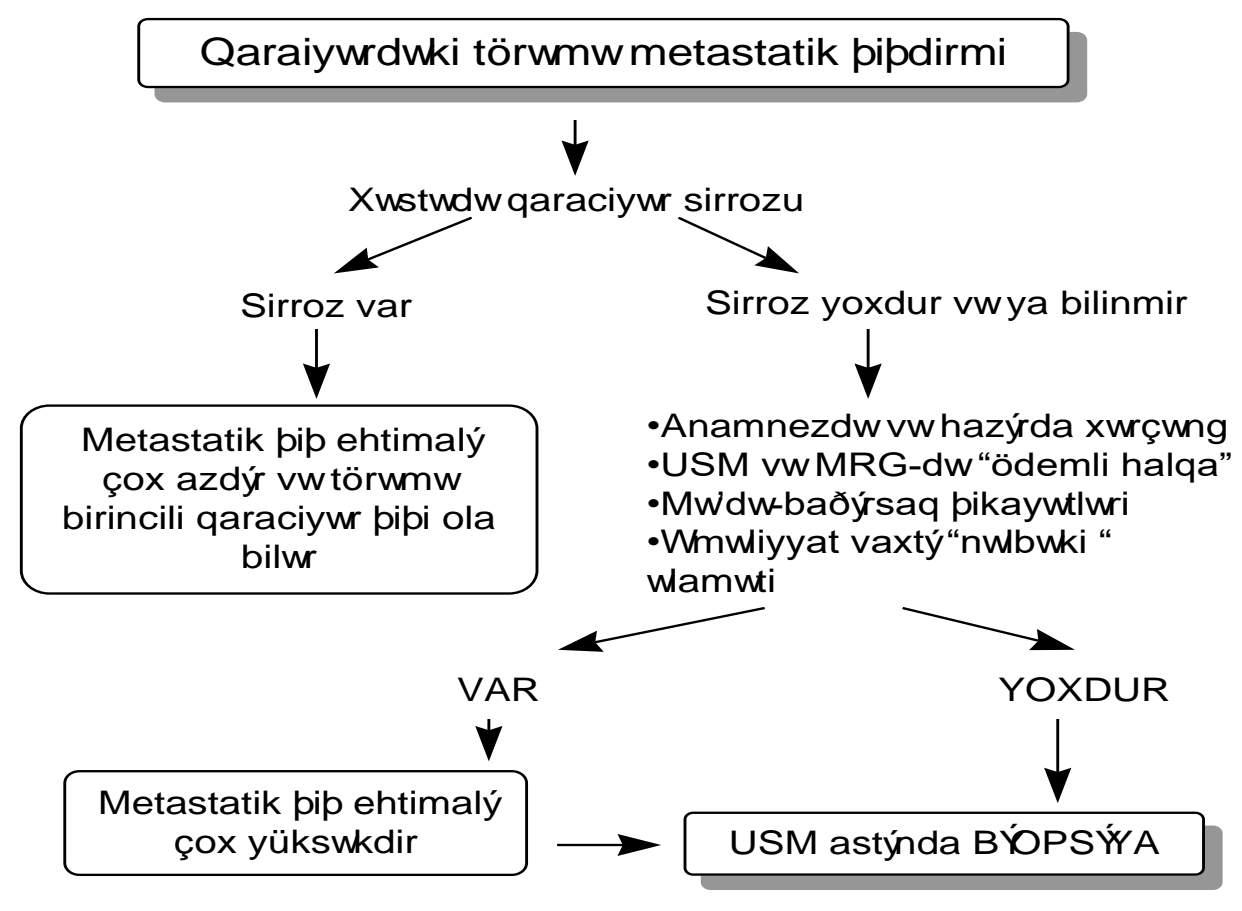

Şəkil. 3. 9. Qaraciyərdəki törəmənin metastatik şiş nöqteyi-nəzərdən araşdırılması

Üçüncü məsələnin həlli, yə’ni rezektabel metastatik şişi olan xəstədə qaraciyərin diğər bölgəsində metastaz olub-olmadığının tə’yini rezeksiya həcmini və rezektabelliyi dəqiq müəyyən etmək üçün çox vacibdir. $\mathrm{Bu}$ məqsədlə əməliyyatönü dövrdə gecikdirilmiş KT, KT-angioqrafiya (arterioqrafiya və ya arterial portoqrafiya) və ya MRT müayinələrinin aparılması lazımdır (Şəkil. 3. 10). KT-angioqrafiya $40-55 \%$ hallarda, gecikdirilmiş iodin-kontrastl $1 \mathrm{KT}$ isə $20-25 \%$ hallarda əlavə metastazları aşkara çıxarır. MRT-nin perspektivləri daha yüksəkdir. Oməliyyat vaxtı səthdə yerləşən əlavə metastazları müəyyən etmək üçün palpasiya, dərindəkilər üçün isə əməliyyatdaxili USM çox həssas bir metoddur. 


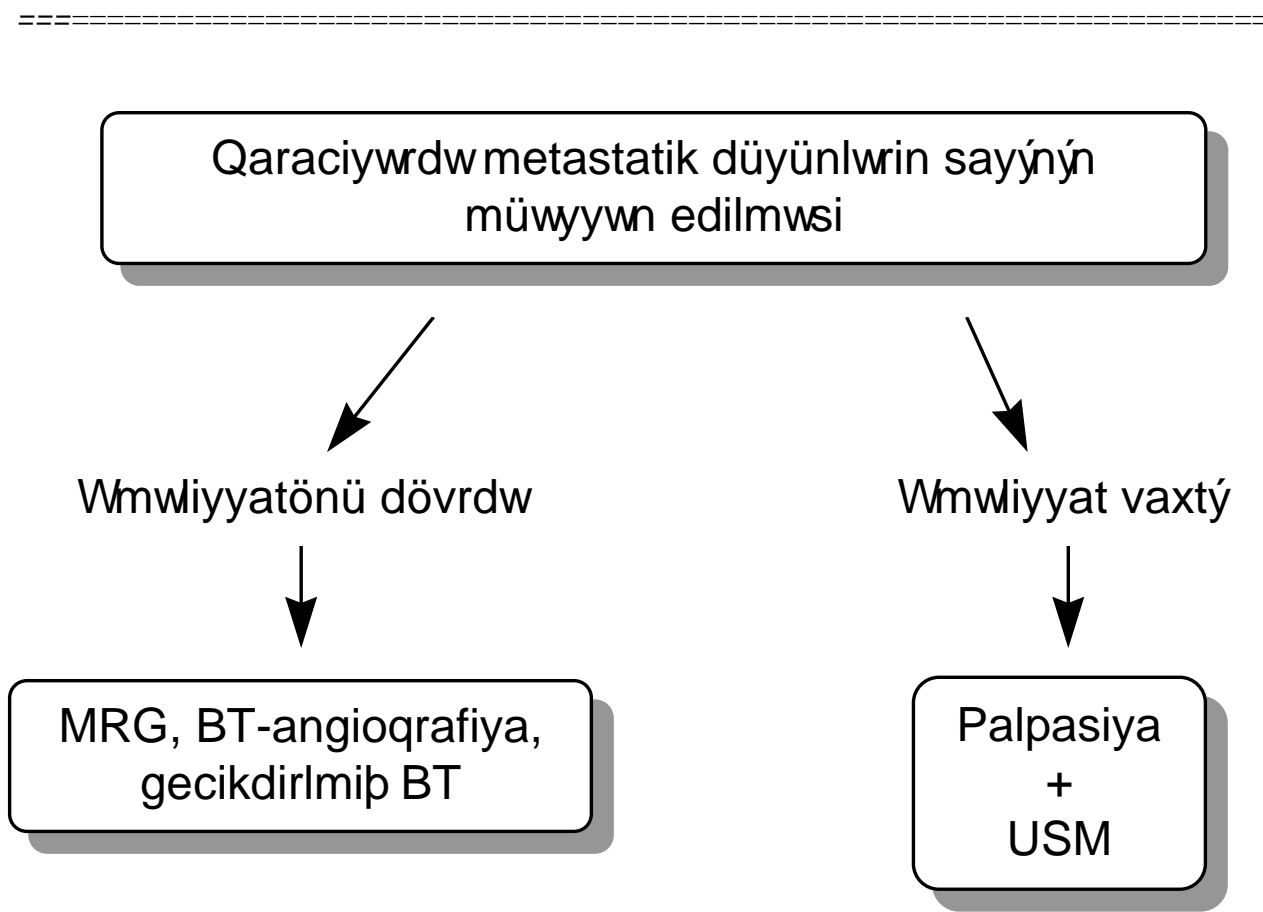

Şəkil. 3. 10. Qaraciyərdəki metastatik düyünlarin sayının müəyyən edilməsi

Müalicəsi. Metastatik şişlərin müalicəsini müəyyən edən üç əsas amil-şiş mənbəyinin aradan qaldırılması imkanı, ekstrahepatik yayılmanın olub-olmaması va qaraciyardə yayılma daracosidir (Şəkil. 3. 11).

Rezeksiya metastatik şişlərin radikal müalicə üsuludur. Lakin, əksər hallarda (75-80\%) hər iki pay tutulduğu və ekstrahepatik metastazlar olduğu üçün metastatik şişlərdə rezeksiya imkanları çox az olur(10\%). Metastatik rezeksiya edilməsi üçün xəstəlik və qaraciyərdəki metastaz rezektabel olmalıdır, yə’ni aşağıdakı şərtlər lazımdır:

1. Şişin mənbəyi aradan qaldırılmalıdır

2. Qaraciyərdən kənarda metastaz olmamalıdır

3. Metastaz qaraciyərin bir payını tutmalı, böyük damar və axacaqlara sirayət etməməlidir. 
Rezektabel şişlərdə qaraciyər rezeksiyası ilkin mənbəyin çıxarılması ilə eyni vaxtda və ya 1-1,5 ay sonra aparıla bilər. Íkimərhələli əməliyyatın tərəfdarları daha çoxdur. Hesab edilir ki, şişin mənbəyi çıxarıldıqdan sonra 11,5 ay müddətdə bə'zi şişər kimyaterapiya edilərək kiçilə bilər, və ən vacibi isə, ilk müayinələrdə görünməyən gizli metastazlar ortaya çıxa bilər.

Bu üç şərtdən biri ödənməyən halda şiş qeyri-rezektabel olaraq qabul edilir. Bu halda palliativ və şiş ölçüsünü azaltmaq məqsadi ilo müxtəlif müalicalər tətbiq edilir. Şiş mənbəyi çıxarıldı̆̆ metastaz varsa sistemik kimyaterapiya aparılır. Şiş çıxarıldı̆̆ ekstrahepatik metastaz olmadiğg, lakin qaraciyərdəki şiş qeyri-rezektabel olduğu hallarda iso intraarterial kimyaterapiya vo ya kriodestruksiya aparllır. Şiş kiçilib rezektabel vaziyyatə galarsa rezeksiya edilir. 


\section{Qaraciywrdw metastatik pip}

$\downarrow$

Ýkin munbw aradan qaldýrýldýmý?

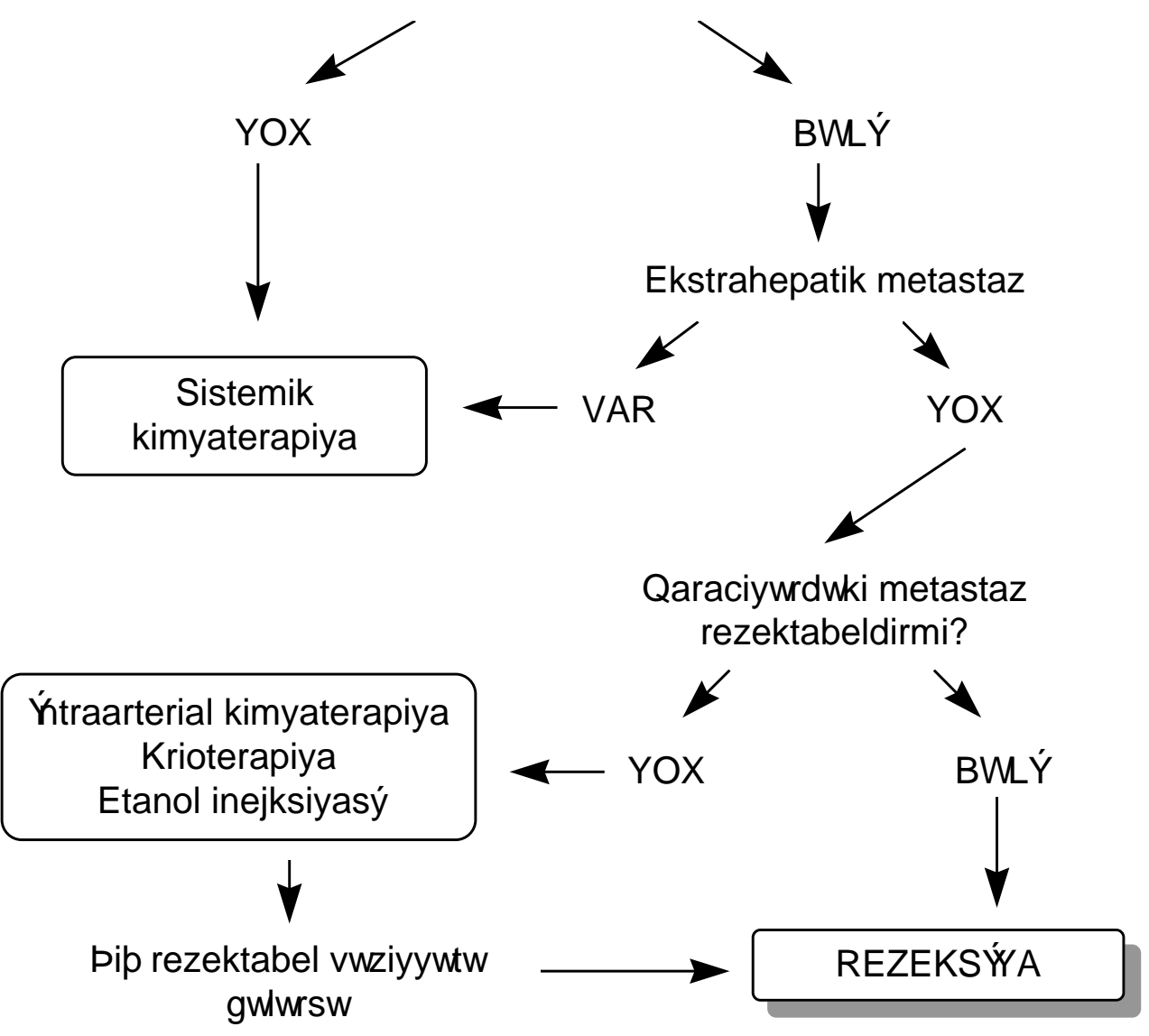

Şəkil. 3. 11. Qaraciyərin metastatik şişlərində ümumi müalicə taktikası 
Qaraciyar rezeksiyasına göstorişlor va oks göstorişlor

\section{QARACIYORIN XOŞ XASSOLI ŞIŞLORI}

\section{HEPTOSELLULAR ADENOMA}

Hepatosellular adenoma (HA) hepatositlardon inkişaf edon xoş xassali, kontraseptiv hormon alan qadınlarda çox müşahida edilan va qanaxmaya meyilli şişdir.

HA qaraciyərin xoş xassəli birincili epitelial şişləri arasında ən çox rast gələnidir və son illər kontraseptiv hormonların (estrogen, progestron) geniş tətbiqi ilə əlaqədar rast gəlmə tezliyi də artmışdır.

Etiologiyasında kontraseptiv hormonların mühüm rolu vardır. HA olan qadınların 90\%-ə yaxınında kontraseptiv istifadə edildiyi mə'lumdur. $\mathrm{Bu}$, qadın cinsiyyət hormonlarının qaraciyər regenerasiyasını artırması ilə izah edilə bilər. Hamiləlik şişin böyüməsinə, hətta partlama və qanaxmasına səbəb ola bilir. Kişilərdə nadirdir, yalnız anabolik steroid qəbul edənlərdə müşahidə edilir.

Morfologiyası. HA ən çox sağ payda (75\%) yerləşir, ortalama ölçüsü 6-8 sm-dir. Mikroskopik olaraq normal hepatositlərdən fərqlənməyən hepatositlərdən ibarətdir, lakin arxitektonikası çox fərqlidir. Qap1 üçlüyü, mərkəzi venası yoxdur. Kompressiyonla əlaqədar ətrafinda fibroz kapsul (prevdokapsul) əmələ gəlir, qanaxma, degenerasya çox rast gəlir. Arxitektonikasına (qapı üçlüyü, mərkəzi venasının olmaması, paycıqsız olması) görə normal qaraciyərdən, öd axacaqlarının olmamasına, hemorragiya və degenerasyaların olmasına görə fokal nodulyar hiperplaziyadan forqlənir.

Klinik gedişinə görə asimptomatik (20\%), simptomatik və ağırlaşmalı formaları vardır. Təzyiqə və qanaxmalara bağlı ağrı və anemiya ən çox rast gələn simptomlarıdır. Qaraciyərin funksiyonal göstəriciləri normal səviyyədədir.

Qanaxma ən çox rast gələn (41\%) ağırlaşmadır. Qanaxma şiş daxilinə və sərbəst qarın boşluğuna ola bilir. Bu halda anemiya, ağrıda artma, qaraciyər funksiya pozulmaları və hemoperitoneum əlamətləri ortaya çıxır. Hemoperitoneum olan hallarda tə'cili əməliyyat lazım gəlir.

İkinci ağırlaşması malignizasiyadır. Uzun müddət davam edən adenomlar hepatosellular xərçəngə çevrilə bilər. 
Diaqnostikasında klinik müayinə ilə yanaşı görüntüləmə üsulları əhəmiyyətli yer tutur. Anemiya, ağrı, və kontraseptiv hormon qəbul edən qadınlarda HA şübhəsi yüksəkdir.

Hepatosit kütlasi, hemorragiya va degenerasiya ocaqlarının olması HA-nın görüntüləmə üsulları ilə heterogen görünməsinə səbəb olur. USM-də kəskin sərhədli, hipo-, hiperekoik heterogen törəmə şəkilində görünür. KT-də hipodens heterogen, kontrastlı müayinədə isə, qarışıq tipdə hiperdens törəmə şəkilində görünür. Kontrastlı KT ilə təzə qanaxmalar görünə bilər. MRT-də HSK-ya bənzər heterogen törəmə şəklində görünür, T1-də hiperintens (yağ toxuması olduğu üçün) bölgələri, T2-də isə, izo- (hepatositlər) və hiperintens (qanaxma, nekroz) bölgələri ayırd edilir.. Göründüyü kimi görüntüləmə üsulları ilə adenomaları xərçəngdən ayırmaq çətindir. Adenomlar qanaxmaya meyilli olduqları üçün biopsiyə ehtiyatla yanaşılmalıdır.

Müalicasində əsas prinsip kontraseptiv hormonların kəsilməsi və şişin çıxarılmasıdır (rezeksiya). Bə’zi müəlliflər kontraseptivlərin kəsilməsi nəticəsində hepatik adenomların kiçildiyini bildirirlər. Lakin qanaxma tez-tez rast gəldiyi və malignizasiya ehtimalı olduğu üçün klinik formasından (asimptomatik, simptomatik, ağırlaşmalı) asılı olmayraq şişin çıxarılması məsləhət görülür. Diğər tərəfdən hazırkı müayinə üsullarının HA ilə HSX birbirindən dəqiq ayırd edə bilməməsi də, əməliyyata meyli artırır. Şiş çox böyük olduqda, xəstənin ümumi vəziyyəti rezeksiyaya əks göstəriş təşkil etdiyi hallarda arterial embolizasiya tətbiq edilir (Şəkil 3.12).

\section{FOKAL NODULYAR HIPERPLAZIYA}

Fokal nodulyar hiperplaziya (FNH) normal hepatositlardon amolo galmiş hamartomatoz va ya yerli zadəlanməyə, xüsusən damar anormalliğl bölgalarində inkişaf edən regenerativ törəmə olduğu hesab edilir.

Hepatik adenomadan sonra ən çox rast gələn birincili xoşxassəli epitelial şişdir 


\section{Hepatik adenoma}

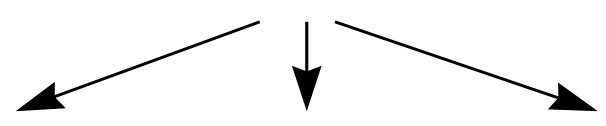

Asimptomatik Simptomatik Aoýlapmalý

Rezektabel

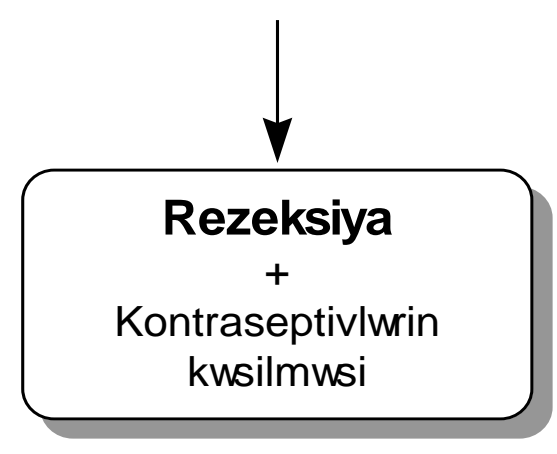

Qeyri-rezektabel

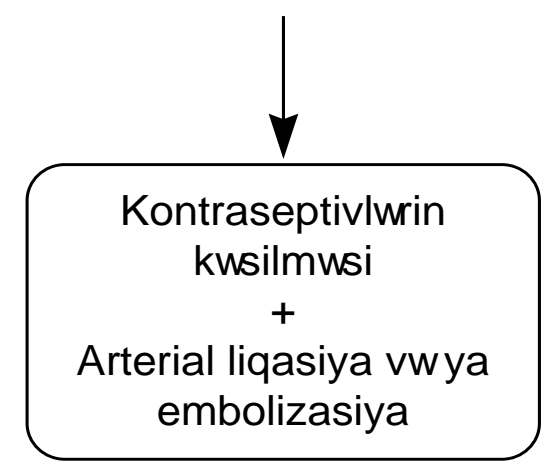

Səkil 3.12. Hepatik adenomanın müalicasi

Etiologiyası tam bilinmir. Hemangiomalarla birliktə rast gəlməsi (23\%) və dopler USM-də arterio-venoz şuntların tapılması bu xəstəliyin damar zədələnməsi bölgələrindən inkişaf etmə ehitmalını artırır. Hepatik adenomadan fərqli olaraq kontraseptiv istifadəsi ilə əlaqəsi zəifdir (11\%).

Morfoloji olaraq, FNH normal hepatositlərə çox yaxın hüceyrələrdən təşkil olunmuş, arakəsmələrlə paycıqlara bölünmüş və böyük törəmələrdə mərkəzdə çapıq toxuma vardır. Arakəsmələrdə öd yolları və damarlar 
mövcuddur. Bariz qap1 üçlüyü, mərkəzi venası yoxdur. Әtraf toxumalara təzyiq nəticəsində fibroz kapsul (psevdokapsul) əmələ gəlir. Nekroz və hemorragiya nadir olduğu üçün kalsifikasiyonlar müşahidə edilmir. Ölçüləri adətən (85\%) 5 sm-dən kiçikdir, az hallarda (20\%) sayı iki və daha çox olur. Paycıql1, arakəsmələrdə öd yolları və damarların, mərkəzində çapıq toxumanın olması, kalsifikasyon və ağırlaşmalarının nadir rast gəlməsi ilə hepatik adenomadan fərqlənir.

Klinik olaraq asimptomatik, simptomatik vo az hallarda ağırlaşmalarla müşahidə edilir. FNH əksər hallarda 5 sm-dən kiçik olduğu üçün ciddi əlamətlər vermir və adətən təsadüfi müayinələrdə ortaya ç1xır. Simptomatik dövrdə böyümə və ətrafa təzyiqlə əlaqədar ağrı ortaya çıxır. Hemorragiya bu xəstəlikdə nadir hallarda rast gəlməsinə baxmayaraq kontraseptiv alanlarda artır (10\%). Nadir hallarda sürə’tli böyümə müşahidə edilir. Malignizasiya ehtimalının çox azdır.

Diaqnostikasında USM, KT, MRT, radioizotop müayinə və biopsiya əsas yer tutur. USM-də hipoekoik, hömogen və mərkəzində çapıq toxuma görünür. Dopler USM-də arterio-venoz şuntlar görünə bilir. Kontrastsız KTdə homogen hiperdens, kontrastlida isə, homogen hiperdens və ya izodens görünür. 15\% hallarda mərkəzi çapıq görünə bilir. MRT ilə bu törəmələr T1və T2-də homogen izointens, mərkəzi çapıq isə, T1-də hipointens, T2-də hiperintens görünür. Radioizotop müayinədə adenomalardan fərqli olaraq FNH-də izotop tutulumasında artma müşahidə edilir. FNH-ın spesifik görüntüləmə əlaməti yoxdur. Qeyd edilən əlamətlər HSK-da da görünə bildiyi üçün bir-birindən ayrılması çətindir. Ona görə də iynə və ya açıq biopsiya diaqnozu dəqiqləşdirmək üçün ən güvənli üsuldur.

Müalicəsi. FNH az hallarda çox böyük ölçülərə çatdı̆̆ı, nadir hallarda ağırlaşmalara səbəb və malignizasiya ehtimalı çox az olduğu üçün həm asimptomatik, həm də simptomatik formalarda müşahidə edilməsi tövsiyə olunur. Ağırlaşma hallarının olmaması üçün bu xəstələrdə oral kontraseptivlər istifadə edilməməlidir. Törəmə sür’ətlə böyüdüyü hallarda rezeksiya lazım gəlir (Şəkil 3.13). 


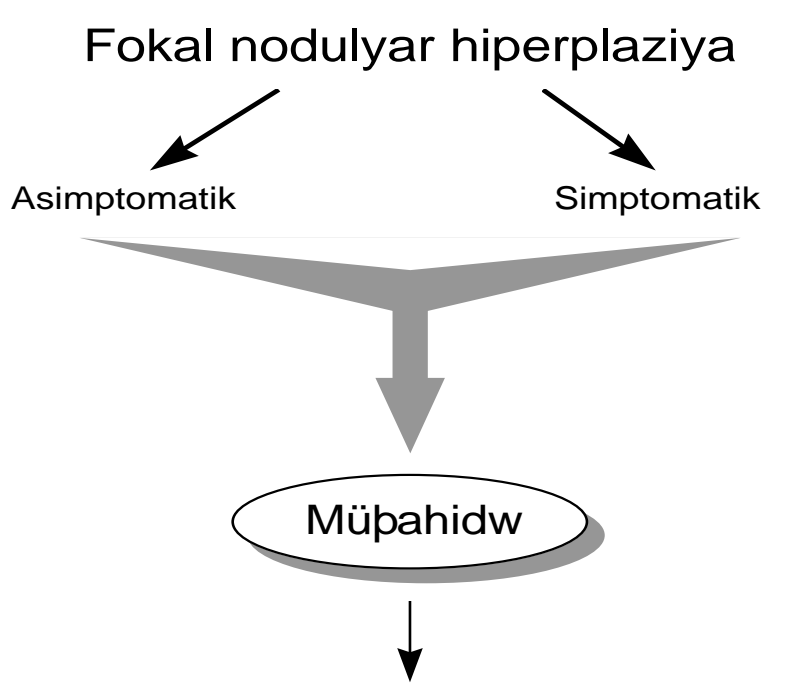

Sür'utli böyümw

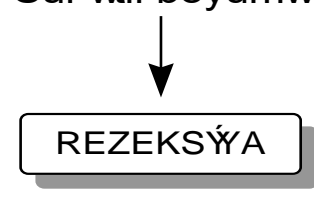

\section{Şəkil 3.13. Fokal nodulyar hiperplaziyanın müalicəsi}

\section{HEMANGIOMA}

Hemangioma qan damarlarının kistşəkilli genişlanməsi va qan dövranının yavaşıması ila xarakteriza olunan törəmadir. Genişlənən damardan asılı olaraq kapillyar və kavernoz hemangiomalar ayırd edilir. Kapillyar hemangiomlar kapillyarların genişlənməsi olub çox kiçikdirlər. Kavernoz hemangiomalar isə, böyük damarların genişlənməsi nəticəsində əmələ gəlir və ölçüsünə görə kiçik $(<5 \mathrm{sm})$, orta $(5-10 \mathrm{sm})$ və böyük $(>10 \mathrm{sm})$ ola bilir. Klinik gedişinə görə isə, asimptomatik, simptomatik və ağırlaşmış formalar1 var.

Hemangiomalar qaraciyər törəmələri arasında metastatik şişlərdən sonra ikinci, xoş xassəli şişlər arasında isə, birinci yerdə duran törəmədir. 
Qadınlarda kişilərdən 5 dəfə çox rast gəlir. İnsanlarda 0,4-7\% hallarda rast gəlir.

Hemanfiomaların etiologiyası vo patogenezi dəqiq mə'lum deyil. Gadınlarda, kontraseptiv hormonlar qəbul edənlərdə və çox uşaq doğanlarda daha çox rast gəldiyinə əsaslanaraq genital hormonlar etioloji faktor hesab edilir. Bir çox hallarda qaraciyərlə yanaşı diğər orqanlarda rast gəlir.

Morfologi olaraq kapillyar hemangiomalar kapillyarların genişlənməsi və yumaqşəkilli toplanmasından ibarətdir. Kavernoz hemangiomalar bir-birindən qalın fibroz arakəsmələrlə ayrılmış kavernalardan ibarətdir. Kavernaların daxili divarı endotellə örtülüdür. Kavernalarda qan hərəkəti yavaşladığı üçün tromblar əmələ gələ bilir ki, bu da fibrozisin və kalsifikasyonların əmələ gəlməsinə səbəb ola bilir. Böyük hemangiomalarda tromblaşmanın tez-tez təkrarlanması trombositopeniyaya səbəb ola bilir (Kasabach-Meritt sindromu). Müşahidə edilən hemangiomaların 90\%-i kiçik ( $<5 \mathrm{sm})$, yerdəqalan hissəsini isə, orta (5-10 $\mathrm{sm})$ və böyük (>10 sm) hemangiomalar təşkil edir.

Klinik olaraq hemangiomlar asimptomatik, simptomatik və ağırlaşmalı seyr edə bilir. On çox rast gələn kiçik hemangiomlar $(<5 \mathrm{sm})$ adətən $(70 \%)$ əlamət verməzlər. Hemangiomanın böyüyərək ətrafa təzyiq etməsi və tromboz nəticəsində diskomfort, ağrı, hərarətin artması müşahidə edilir. Bu əlamətlər böyük hemangiomalarda (>10 sm) daha barizdir, lakin böyük hemangiomalar az rast gəlir (10\%).

Ağırlaşmalar böyük və səthdə yerləşən hemangiomalarda müşahidə edilir. Hemangiomun partlaması və qanaxma çox az $(4,5 \%)$ rast gələn ağırlaşmadır, çünki hemangiomların qalın fibroz qatı vardır. Böyük və çoxlu trombozlarla əlaqədar trombositopeniya və absesləşmə də az rast gəlir. Hemangiomaların malignizasiya ehtimalı yoxdur, lakin, fokal nodulyar hiperplaziya ilə birlikdə rast gələ bilər.

Diaqnostikası. USM, kontrastl1 KT və MRT hemangioma diaqnostikasında mühüm yer tutur. Biopsiya səthdə yerləşmiş hemangiomalarda qanaxma təhlükəsi yaratdığı üçün adətən tövsiyə edilmir. Ona görə də, görüntüləmə üsulları ilə diaqnozun mühüm əhəmiyyəti vardır. USM-də kiçik hemangiomalar hiperekoik və homogen görünür. Orta və böyük hemangiomalar, xüsusən də tromboz olduğu halllarda heterogen (qanla 
dolu böyük kaverna, fibroz toxuma, tromb) görünürlər. Dopler USM də qan axını heç görünmür və ya çox zəif ( $<50 \mathrm{sm} / \mathrm{san})$ qeyd edlir.

Kontrastsız KT-də hemangiomalr dəqiq sərhədli hipodens törəmələr kimi görünürlər. Kontrastlı dinamik $\boldsymbol{K T}$ kavernoz hemangiomaların diaqnostikasında mühüm əhəmiyyət kəsb edir. $\mathrm{Bu}$ müayinədə hemangiomaların qan dövranı xüsusiyyəti- periferiyadan mərkəzə doğru zəif qan axını- ortaya çıxır. Belə ki, kontrast verildikdən həmən sonra törəmənin periferiyası kontrastlaşmağa başlayır, 8-10 dəq sonra isə, kontrast törəmənin mərkəzində toplanır.

Angioqrafiyada kavernalar aydın görünür.

MRT-nin tətbiqinə qədər dinamik KT hemangiomaların müəyyən edilməsi üçün istifadə edilən ən güvənli noninvaziv üsul idi. MRT hemangiomaların diaqnozunu 90-95\% dəqiqliklə müəyyən edir. KT-dən fərqli olarq MRT hemangiomaların daxili quruluşunu daha aydın göstərir. MRT-də hemangiomlar düzgün kənarl1, kapsulsuz, kiçik ölçülərdə homogen, orta və böyük ölçülərdə isə, heterogen görünürlər. T1-də izo-, hipointens, T2də isə, hiperintens görünürlər. Gadolinium-DTPA kontrası ilə çəkilən MRTdə də periferiyadan-mərkəzə kontrastlaşma əlaməti ortaya çıxır.

Ovvəllər hemangiom şübhəsi olan xəstələrdə biopsiya edilməməsi məsləhət görülürdü. Lakin, son zamanlar incə iynəlarla və törəməyə nomal qaraciyər toxumasından keçmək şərti ilə biopsi edilə bilir. Bu texnika qanaxma təhlükəsini ciddi şəkildə azaldır. Bunu yerinə yetirmək üçün biopsiyanı görüntüləmə üsulları nəzarətində aparmaq lazımdır.

Omoliyyat vaxtı törəmənin hemangioma olub olmadığını tə'yin etmək üçün aşağıdakı simptomlara diqqət etmək lazımdır. Hemangiomalar tünd qırmızı rəngdə, yumşaq, elastikdirlər, döş qəfəsində təzyiq artdıqda (Valsalava sınağı) böyüyürlər. Bəd xassəli şişlər isə, bilindiyi kimi adətən açıq rəngli və sərt olurlar.

Müalicəsi klinik gedişindən asılı olaraq dəyişir (Şəkil 3.14). Asimptomatik hemangiomaların müşahidə edilməsi məsləhət görülür. Simptomatik və ağırlaşmalı formalarda rezeksiya və ya enokulyasiya edilməsi lazım gəlir. Rezektabel olmayan hemangiomlarda kortikosteroid müalicəsi, arterial embolizasiya və liqasiya istifadə edilir. Qanaxma 
ehtimalının az olduğunu, malignizasiyanın rast gəlmədiyini nəzərə alaraq, son illər hemangiomların müalicəsində rezeksiya üsuluna daha az yer verilir.

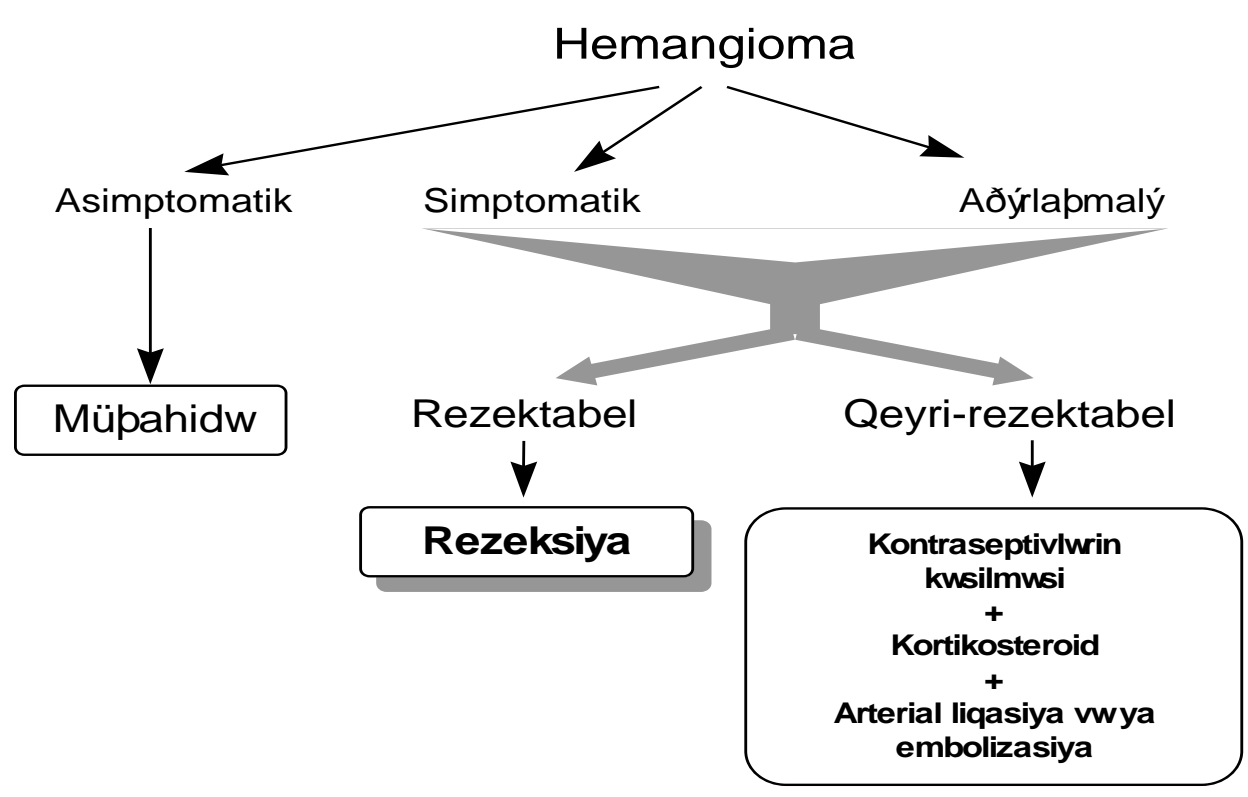

Şəkil 3.14. Hemangiomanın müalicəsi

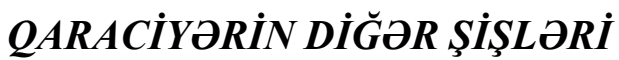

Hepatoblastoma uşaqlarda ən çor rast gələn (50\%) bəd xassəli birincili qaraciyər şişidir. Histoloji cəhətdən embrional hepatositlərə bənzəyən hüceyrələrdən təşkil olunmuşdur. Şiş daxilində osteoid, gı̆̆ırdaq, fibroz tipli mezenximal toxumalara da rast gəlmək olur.

Әn çox sağ payda yerləşir, ölçüləri 1-2 sm-dən 10-15 sm-ə qədər dəyişə bilir. Alfa-fetoprotein əksər hallarda yüksəlir. Osteoid toxumanın, və nekrozun olması ilə əlaqədar şiş daxilində kalsifikasionlara tez-tez $(30 \%)$ müşahidə olunur. Görüntüləmə əlamətlərinə görə qaraciyərin diğər 
şişlərindən ciddi fərqlənmir- hipoekoik, hipodens, hipervaskulyar, T1-də hpointens, T2-də hiperintens, heterogen.

Uşaq yaşlarında qaraciyərdə törəmə tapılarsa ilk növbədə hepatoblastomadan şübhələnmək lazımdır. Dəqiq diaqnozu patohistoloji müayinədə qoyulur.

Qaraciyər rezeksiyası radikal müalicə üsuludur. Hepatosellular xərçəngdən fərqli olaraq hepatoblastoma əksər hallarda $(60 \%)$ rezektabel vəziyyətdə olur. Buna baxmayaraq ölüm halları çox yüksəkdir (70\%).

Angiokarsinoma qaraciyərin nadir rast gələn bəd xassəli şişi olub, Kupffer hüceyrələrindən inkişaf etdiyi ehtimal edilir. Odəbiyyatda müxtəlif adlarla - hepatik angiosarkoma, hemangioendotelial sarkoma, Kupffer hüceyrə sarkomu, hemangiosarkoma - adlandırılır.

Etiologiyasında torotrastın, arsenidin, vinil xloridin rolu olduğu mə'lumdur. Sür’ətlə böyüyərək çox erkən metastazlar verir və ən çox dalağa $(80 \%)$ və ağciyərə $(60 \%)$ yayılır.

Görüntüləmə üsulları ilə diğər şişlərdən fərqləndirmək çətindir. Hüceyrəspesifik kontrastlı (Kupffer hüceyrələrində tutulan) MRT diaqnostikada yeni perspektivlər açır. Dəqiq diaqnozu patohistoloji müayinə ilə qoyulur.

Müalicəsi erkən dövrlərdə rezeksiyadır. Lakin, əksər hallarda angiosarkoma qeyri-rezektabel vəziyyətdə olur və orta yaşama müddəti 1 ildən azdır.

Qaraciyərin lipoma, leyomioma, mezotelioma, teratoma və s. bəd və xoş xassəli şişləri çox nadir rast gəlir. Bunların klinik və görüntüləmə əlamətləri diğər şişlərinkinə bənzəyir. Dəqiq diaqnozu biopsiyada və ya rezeksiya ilə çıxarılan parçanın patohistoloji müayinəsində qoyulur. Ogər, diaqnoz rezeksiyaya qədər mə’lum olarsa, müalicəsi təbiətinə uyğun olaraq xoş və bəd xassəli şişlərdə olduğu kimidir.

\section{QARACIYYRIN TOXUMALI TÖROMOLORINİN DIFFERENSİAL DIAQNOSTIKASI}

Qaraciyərin toxumalı törəmələrinin aşkar edilməsi və təbiətinin müəyyən edilməsi cərrahi hepatologiyanın ən vacib məsələsidir. Müasir 
görüntüləmə üsulları 1 sm-dən böyük törəmələri aşkar etməkdə yüksək həssaslıq (90\%-ə qədər) göstərirlər.

İkinci məsələ-şişin təbiətinin müəyyən edilməsi, hazırda tam həllini tapmamışdır. Çünki, müasir görüntüləmə üsulları törəmənin hüceyrəvi tərkibini dəqiqliklə göstərmirlər, laborator göstəricilər spesifik deyildir, törəmələrin çox az hissəsinin spesifik klinik, laborator və görüntüləmə əlamətləri vardır. Şişin təbiətini dəqiq tə’yin etmək üçün istifadə olunan biopsiya invaziv olduğu, ağırlaşma təhlükəsi (qanaxma, şişin yayılması) törətdiyi üçün həmişə istifadə edilmir.

Bunları nəzərə alaraq qaraciyərin toxumalı törəmələrinin diaqnostikasında aşağıdakı prinsipləri rəhbər tutmaq lazımdır:

1. Klinik, laborator və görüntüləmə müayinələrinin nəticələri birlikdə qiymətləndirilməlidir.

2. Klinik,laborator və görüntüləmə müayinələrinin nəticələri diaqnozu dəqiqləşdirmədikdə biopsiya aparılmalıdır.

3. Törəmənin xoş xassəli olduğu dəqiqləşmədikdə, bu törəmə bəd xassəli kimi qə’bul edilərək müalicə edilməsi məsləhətdir.

4. $\mathrm{Bu}$ prinsiplərə əməl edərək, törəmələrin kompleks diaqnostikasında aşağıdakı mə'lumatları da nəzərə almaq faydalıdır.

5. Qaraciyərdə ən çox rast gələn toxumalı törəmə sıra isə hemangioma, metastatik şiş və hepatosellular xərçəngdir.

6. Qaraciyərin birincili xoş xassəli şişlərindən fokal nodulyar hiperplaziya nadirdir, adenoma isə başlica olaraq kontraseptiv dormanlar alan qadınlarda və anabolik hormon alan kişilərdə müşahidə edilir. Kişilərdə toxumalı töramalarin bad xassali olma ehtimalı yüksəkdir.

7. Sirrotik qaraciyərdə metastatik şiş olma ehtimalı çox nadirdir (bizim mə'lumatlara görə müşahidə edilməmişdir), hepatosellular xərçəng ehtimalı isə çox yüksəkdir. Bu xəstələrdə hepatosellular xərçəng ilə sirrotik düyün arasında differensasiya aparmaq lazımdır.

8. Anamnezində və hal-hazırda hər hansı bir orqanında bəd xassəli şişi və ya şiş sübhəsi olan xəstələrdə törəmənin metastaz olma ehtimalı yüksəkdir. 
9. Alfa-fetoproteinin yüksək olması hepatosellular xərçəng ehtimalını artırır, lakin normal olması hepatosellular xərçəngi inkar etmir. Çünki, hepatosellular xərçəngin fibrolamellar tipində alfa-fetoproteinin artmır.

10. Metastatik şişlər kistşəkilli də ola bilərlər. Xüsusən, çənbər bağırsağın, mə'dəaltı vəzin və yumurtalıqların musinoz xərçəngləri sistoadenokarsinoma şəklində metastaz verə bilir.

11. Törəmənin homogen və ya heterogen görünməsi bəd xassəli şişlərdə olduğu kimi xoş xassəli şişlərdə də müşahidə edilir.

12. Hissəvi kalsifikasiya və ya nekrozlar həm bəd xassəli, həm də xoş xassəli şişlərdə görünür.

13. Törəmə tamamilə kalsifikasiya olarsa təhlükəsiz hesab edilə bilər.

14. İynə biopsiyalarda ă̆ırlaşmaları azaltmaq üçün onu USM və ya $K T$ nəzarətində aparmaq və törəməyə transhepatik daxil olmaq vo yetorli material almaq lazımdır. Yə'ni törəmə ilə qaraciyər kapsulu arasında normal parenxima olmalıdır. Biopsiya laparoskopik üsulla da aparıla bilər.

$\mathrm{Bu}$ mə'lumatlara əsaslanaraq, qaraciyərin toxumalı törəmələrində diaqnostik alqoritmi aşağıdakı şəkildə verilə bilər (Şəkil 3.15). 


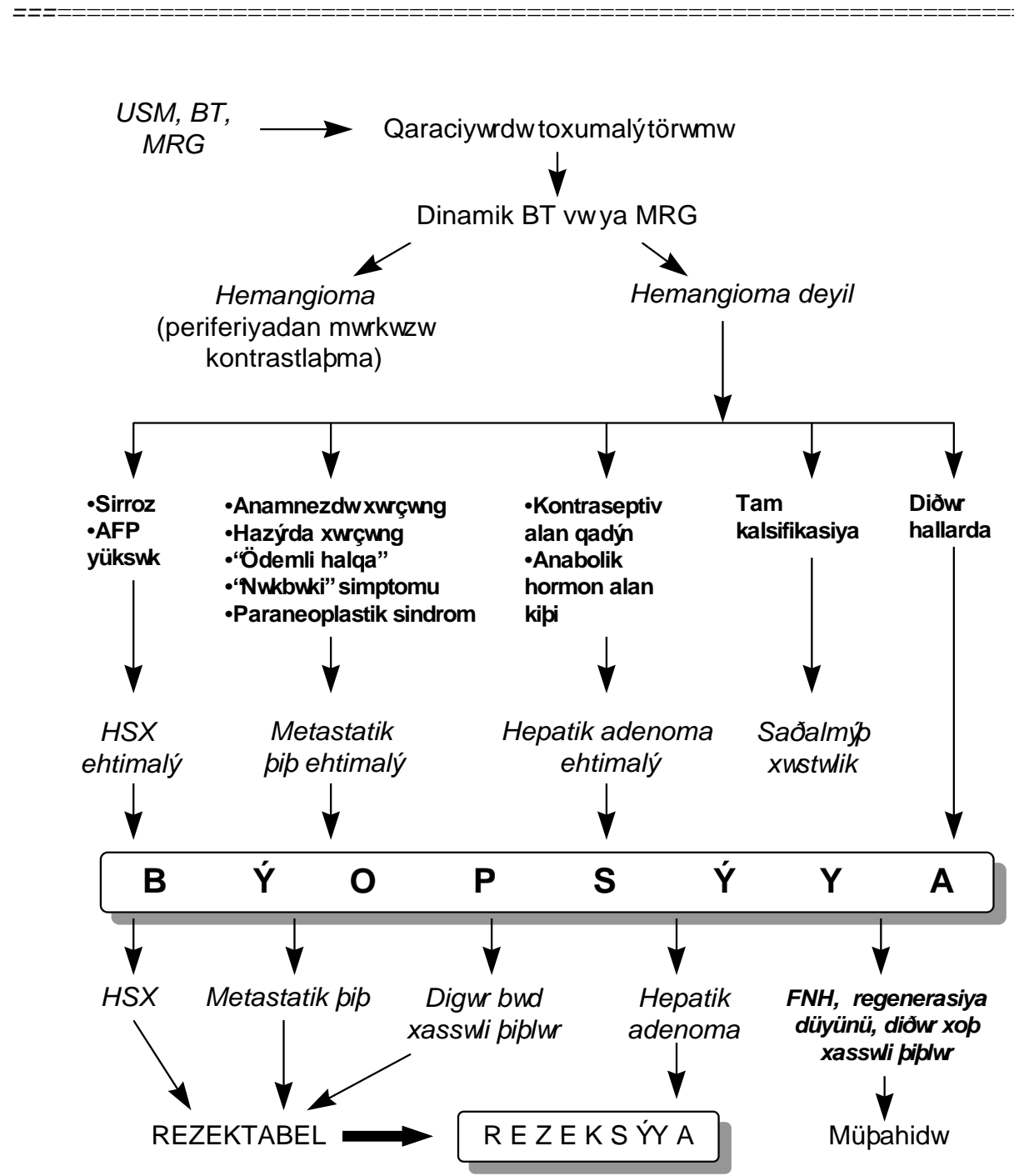

Şəkil 3.15. Qaraciyərdəki toxumalı töroməlorin differensial diaqnostikası

QARACIYOR TRAVMALARI 
Qaraciyar rezeksiyasına göstorişlor va oks göstorişlor

Qaraciyər qarının kut və açıq travmalarında ən çox zədələnən orqanlardan biridir. Qaraciyər zədələnmələrinin müalicə tələb etməyən kiçik hematomalardan başlamış, geniş parenxima destruksiyası və magistral damarların zədələnməsinə qədər dəyişən müxtəlif ağırlıq dərəcələri vardır. Şübhəsiz ki, zədələnmənin ağırlıq dərəcəsi klinik gedişi və müalicə taktikasını müəyyən edən ən əsas amildir.

Hazırda mövcud olan təsnifatlarda qaraciyər yaralanmalarının ağırlıq dərəcələrini tə’yini etmək üçün yaranın ölçüsü əsas kriteriya kimi qə'bul edilir. Ancaq, mə’lumdur ki, qaraciyərdə eyni ölçülü, lakin fərqli lokalizasiyalı yaralar orqanizm üçün müxtəlif dərəcədə təhlükə törədə bilər. Məsələn, qaraciyərin periferik hissəsində 1-2 sm dərinlikdəki yara müalicəsiz də sağala bildiyi halda, qaraciyər venaları və ya qapı bölgəsindəki eyni ölçülü yara həyati təhlükəli qanaxma törədə bilər. Bundan başqa yaralanmanın ağırlıq dərəcəsi təkcə yaranın ölçüsü ilə yox, həm də həyat qabiliyyətini itirmiş toxumaların miqdarı ilə də tə'yin olunmalıdır. Digər tərəfdən, mövcud təsnifatlarda qaraciyərin anatomik xüsusiyyətləri nəzərə alınmamışdır.

Bunları nəzərə alaraq, qaraciyər zədələnmələrinin yeni, xüsusən də, müalicə taktikasını müəyyən edən təsnifatını təqdim edirik. Bu təsnifat Azərbaycan Tibb Universiteti I-Cərrahi Xəstəliklər kafedrasında və Qarabağ müharibəsində Hərbi Səhra Hospitallarındakı təcrubələrimizdən istifadə edilərək hazırlanmışdır.

Takli edilan təsnifat qaraciyarin anatomik xüsusiyyətina va anatomik strukturun zadalanmo daracasina asaslanmışdır. Morfoloji cahatdan qaraciyar damar-axacaq torundan va parenxima kütlasindən ibarat bir orqandır. Ona görə də, zadələnmənin ağırlıq dərəcəsini müəyyən etmək üçün zadəlanən damar-axacaq elementlarinin diametri vo hayat qabiliyyatini itirmiş parenximanın hacmi asas kriteriyalar kimi nəzəro alınmışdır. Zadalənən damar-axacaq elementlorinin diametri qanaxmanın miqdarını, qan dövranı pozulmalarının, öd sızıntısının ağırlıq daracəsini va müalicənin vaxtını, üsulunu müəyyən edən əsas amildir. Travmanın birbaşa to'siri və ya damar zadəlanməsi noticosindo ikincili olaraq amolo galon devitalize olmuş toxumaların miqdarı isə, yaranın carrahi işlənməsinin genişlik dəracasini müəyyən edir. 
Təsnifatın diğər cəhəti isə, ayrı-ayrı ağırlıq dərəcələrində müalicə taktikasının göstərilməsidir və bunlar yaraların ümumi müalicə prinsiplərinə uyğun olmasidır.

Zədələnən damar-axacaq elementinin diametrinə, devitalize olmuş parenximanın miqdarına və yaraların müalicə prinsiplərinə əsaslanaraq qaraciyər zədələnmələri 4 ağırlıq dərəcəsinə ayrılmışdır. (Cədvəl 3.2)

Kiçik $(<2 \mathrm{sm})$, qanaxması və ətrafında nekrotik toxumaları olmayan yaralar I dərəcəli yaralanmalar kimi qə'bul edilir. Bu yaralanmalarda kapillyarlar səviyyəsində zədələnənmə olur, parenxima destruksiyası isə, mikroskopik səviyyədədir. Qanaxma olmadığı və destruksiya çox kiçik olduğu üçün bu yaralanmalar adətən müalicə tələb etmir.

II dərəcəli yaralara 2 sm-dən böyük, aktiv qanaxması olan və makroskopik olaraq devitalize olmuş parenximanın görünən yaraları aid edilir. $\mathrm{Bu}$ zədələnmələrdə subseqmentar səviyyədəki damar-axacaqlar zədələnir, destruksiyaya uğramış parenximanın həcmi seqmentdən kiçik olur. II dərəcəli yaralanmalarda qanaxmanı dayandırmaq və devitalize parenximanı çıxarmaq lazım gəlir. Qanaxma nisbətən kiçik damarlardan olduğu üçün sadə hemostaz üsullar1- koter, müvəqqəti sıxma, hemostatik süngərlər və s. - adətən yetərli olur.

III dərəcəli yaralanmalarda aktiv davam edən qanaxma və seqmentar səviyyədə parenxima destruksiyası müşahidə edilir. II dərəcədən fərqli olaraq bu yaralanmalarda seqmentar səviyyədəki damarlar zədələnir və qanaxmanı dayandırmaq üçün sadə hemostaz üsulları yetərsiz olur. Qanaxmanı dayandırmaq üçün Pringler manevrası tətbiq edilərək, qanaxma azaldılır,sonra hepatotomiya edilərək qanaxan damar və zədələnən axacaq tapılaraq bağlanılır. Zədələnən damarın bağlanması qaraciyərdə əlavə nekroz əmələ gətirmir və yalnız ilkin nekrozu çıxarmaq lazım gəlir. Beləliklə, nekroektomiya, qap1 sıxacı, hepatotomiya, zədələnən damar və axacağın selektiv bağlanmasının lazım gəlməsi və bunun qaraciyərdə ikincili nekroz törətməməsi III dərəcəli yaralanmaların səciyyəvi cəhətidir.

Codval 3.2.

Qaraciyər yaralanmalarının təsnifatı 
Qaraciyar rezeksiyasına göstorişlor vo əks göstorişlor

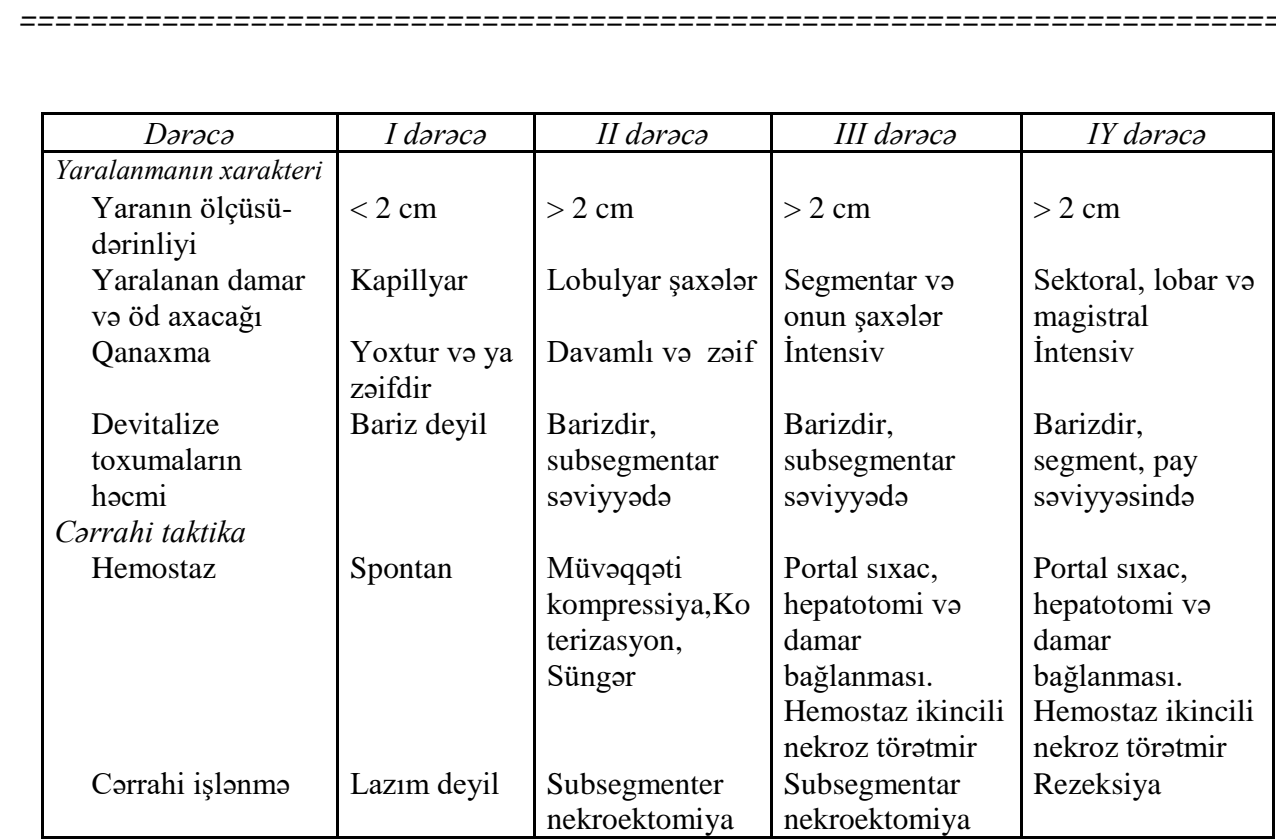

IV dərəcəli yaralanmalar qaraciyərin ən ağır travmaları olub, intensiv qanaxma, parenximada geniş zədələnmə ilə xarakterizə olunur və rezeksiya tələb edən zədələnmələrdir. Bu zədələnmələrdə adətən qaraciyərin böyük damarları zədələnir, pay və daha çox səviyyədə parenxima nekrozu müşahidə edilir. Böyük damarların zədələnməsi və bağlanması nəticəsində ikincili nekrozlar əmələ gəlir. Bu zədələnmələrdə adətən lobektomiya və daha böyük rezeksiyalar aparmaq lazım gəlir.

Beləliklə, böyük səviyyədəki damar-axacaqların zədələnməsi, pay və daha böyük səviyyədə birincili və ikincili nekrozların olması və rezeksiyanın lazım gəlməsi IV dərəcəli yaralanmaların səciyyəvi cəhətidir.

Nəticə olaraq, qaraciyər zədələnmələrində qaraciyər rezeksiyaları aşağıdakı hallarda göstəriş sayılır:

1. Təftiş vaxtı seqment, sektor, pay səviyyəsində nekroz.

2. Zədələnən böyük intra- və ya ekstrahepatik damarların bağlanması nəticəsində əmələ gələn ikincili nekrozlar. 
Belalikla, qaraciyarin morfoloji xüsusiyyatina, zadəlanon damaraxacaq elementinin diametrina, hayat qabiliyyatini itirmiş parenxima hacminə asaslanan təsnifat müalicə taktikasını müəyyən etməyə imkan verir.

\section{QARACIYYR REZEKSIYYASINA DİĞӘR GÖSTORIŞLӘR}

Intrahepatik xolelitiaz iki səbəbdən baş verir. Öd kisəsində əmələ gəlmiş daş retroqrad olaraq qaraciyərdaxili axacaqlara keçir. Öd yolları xəstəlikləri nəticəsində daş birincili olaraq qaraciyərdaxili axacaqlarda meydana gəlir. Karoli xəstəliyi, xolangitlər, öd yolları anomaliyaları, travmaları, xolestatik xəstəliklər qaraciyərdaxili daşların əmələ gəlməsinə səbəb ola bilir.

Daşlar xolangitin baş verməsinə və ya davam etməsinə şərait yaradır, öd yollarını tıxayaraq mexaniki sarılıq, atrofiya, hətta xolangiokarsinoma törədə bilirlər.

Diaqnostikasında USM və xolangioqrafiya həlledici rol oynayır.

Daşları endoskopik yolla və ya əməliyyat vaxtı xoledoxtan çıxarmağa çalışılır. Bu mümkün olmadıqda, uzunmüddətli mexanik sarılıq və xolangitlə əlaqədar qaraciyərdə atrofiya, degenerasiya olarsa zədələnən bölgənin rezeksiyası lazım gəlir.

Canlıdan qaraciyər köçürülməsi son illər tətbiq edilməyə başlanmışdır. Beyin ölümü olan donorların sayında azalma və qaraciyər alıcılarının artması transplantalogiyada "orqan q1tlığı" problemini yaratmışdır. Bu problemi həll etmək üçün bir çox yollar axtarılmaqdadır:

- Beyin ölümü olan donordan alınan qaraciyəri iki yerə bölüb hərəsini bir xəstəyə köçürərək bir donorla iki alıcıyı orqanla tə’min etmək.

- Alıcının canlı və sağlam qohumlarından qaraciyərin bir parçasını alıb köçürmək

- Ürək fəaliyyəti dayanmış ölüdən orqan almaq

- Heyvanlardan orqan köçürülməsi - ksenotransplantasiya 
Qaraciyor rezeksiyasına göstorişlor vo əks göstorişlor

Bu üsullardan ilk ikisi klinik praktikada istifadə edilməkdədir. Diğər ikisi isə hələlik eksperimental səviyyədədir.

Qaraciyər rezeksiyası texnikasındakı irəlləyişlər sayəsində normal qaraciyərdə aparılan rezeksiyaların ağırlaşmaları azalmışdır. $\mathrm{Bu}$ isə, canlı vericidən qaraciyər parçası alınmasının donor üçün təhlükəsini xeyli azaltmağa imkan vermişdir.

Canlıdan qaraciyər köçürülməsi üçün donorda qaraciyərin sol payı və ya II+III seqmentlər rezeksiya edilir. Rezeksiya vaxtı parçalar işemiyaya uğradılmır və damar ayaqcıqları saxlanılır. Alıcıda qaraciyər parçası heterotopik və ya ortotopik şəkildə yerləşdirilir. Damar ayaqcıqları kiçik olduqda plastik material istifadə edilir. Qaraciyərdən hansı parçanın alınması alıcının yaşından və çəkisindən asılıdır. Yaşlı alıcılar üçün donordan sol pay, uşaq yaşlarındakı alıcılar üçün isə, II+III seqmentlər alınır.

Donorun qaraciyər vericisi olması üçün aşağıdak1 şərtlər mühümdür:

1. Donor yaxın qohum olmalı və orqanını verməyə könüllü olmalidir.

2. Qan qrubu alıcının qan qrubu ilə eyni olmalıdır.

3. Qaraciyərdə heç bir xəstəlik olmamalıdır

4. Diğər orqan və sistemlərində hər hansı bir xəstəlik olmamalıdır.

5. Hepatit virusları ilə yoluxmamalı və daşıyıcısı olmamalıdır.

6. Donor ilə alıcı arasında limfositar reaksiya mənfi olmalıdır.

Bir sözlə, donor könüllü, praktik sağlam olmalı va alıcı ila immun konflikt ehtimalı olmamalıdır. Ona görə də, donorlar əməliyyatdan əvvəl hərtərəfli müayinədən keçməlidirlər.

\section{QARACIYORIN REZEKTABELLIYI}

Xəstəliyin rezektabel qə'bul edildikdən sonra ikinci məsələnin qaraciyərin rezektabelliyi məsələsinin həllinə keçilir. Qaraciyərin rezektabelliyi dedikdə, xəstənin qaraciyərinin planlanan rezeksiyaya davam gətirib-gətirməyəcəyi, başqa sözlə, "qaraciyərin planlanan hissəsi 
çıxarıldıqdan sonra qalan hissə kompensasiya və regenerasiya edərək funksiyasını bərpa edəcəkmi ?" məsələsi nəzərdə tutulur. Әslində, qaraciyərin rezektabelliyi əməliyyatdan sonrak1 qaraciyər yetməzliyinin proqnozlaşdırlıması deməkdir. Çünki, rezeksiyadan sonra baş verən ağırlaşmaların əksəriyyəti, xüsüsən, həyati təhlükə daşıyanları birbaşa, və ya dolayı olaraq qaraciyərin funksional yetməzliyi ilə əlaqədardır. Bunlar ya yetməzliyin nəticəsində ortaya çıxır (assit, intoksikasiya, qaraciyər yetməzliyi, varikoz qanaxmalar, davamlı sarılıq və s.), ya da yetməzliyə səbəb olurlar (arterial və ya venoz trombozlar, absess, qanaxmalar, şok, sepsis, mexaniki sarılıq və s.).

Böyük həcmli rezeksiyalarda (50\%-dən çox) bu məsələnin həlli qaraciyər cərrahiyyəsin ən aktual problemlemlərindən biridir və bu günə qədər dəqiq həll edilməmişdir.

Qaraciyər rezektabelliyinin əsas məsələ, qalan qaraciyər parçasının əməliyyatdan sonrakı tələbatı ödəyə bilmə imkanlarının tə’yini və regenerasiya, funksional kompensasiya proseslərini poza bilən faktorların müəyyən edilməsidir. $\mathrm{Bu}$ isə, rezeksiya həcmi, qaraciyərin funksional ehtiyatları və qaraciyərin yükünü artıran faktorlardırn birlikdə qiymətləndirilməsi vasitəsi ilə mümkündür.

Normal qaraciyər 75-80\% rezeksiyaya davam gətirə bilir. Ona görə də, bu səviyyə normal qaraciyərdə aparılan rezeksiyaların üst həddi sayılır. Kəskin hepatit və hepatik koma istənilən tipli rezeksiyaya əks göstəriş hesab edilir.

Qaraciyərdə xronik parenxima xəstəliyi olan və ya qaraciyər funksiyasını pozan faktorlar mövcud olduğu hallarda rezktabelliyi tə'yin etmək üçün müxtəlif üsullar vardır. Bu üsullar başlıca olaraq iki əsas prinsipə əsaslanır: qaraciyərin funksional ehtiyatlarının tə'yini və qalan qaraciyərə mənfi tə'sir göstərən amillərin tə'yini. Qaraciyərin funksional ehtiyatlarını tə'yin etmək üçün qaraciyərin mövcud vəziyyətinin öyrənilməsi (Child təsnifat1, xolinesteraza səviyyəsi) və funksional yükləmə (bromsulfalein sinağı, indosianin yaşıl sınağı, amidopirin, lidokain, qalaktoza və s.) üsullarından istifadə edilir. Qalan qaraciyərə tə'sir edən amillərin tə'yinində isə başlıca olaraq, multivariant analizdən istifadə edilir. 
Child təsnifatı qaraciyərin funksional vəziyyətini müəyyən etmək üçün istifadə edilən ən qədim üsuldur. Oslində sirrozun ağırlıq dərəcəsini müəyyən etmək üçün təklif olunmuş bu üsul, hazırda rezeksiyalarda proqnozlaşdırma üçün də geniş istifadə edilir. Qanda albuminin, bilirubinin miqdarına və assitin xarakterinə əsaslanaraq qaraciyərin sintetik, detoksikasyon və hemodinamik funksiyaları haqqında mə'lumat alınır. Bu təsnifata protrombin miqdarını (Child-Pugh təsnifat1) və ya ensefalopatiya dərəcələri (ChildTurgott təsnifatı) əlavə edilərək, yəni təsnifatlar yaradılmasına baxmayaraq təsnifatdakı əsas prinsip dəyişməmişdir. Child təsnifatına görə, qaraciyərin üç funksional vəziyyəti ayırd edilir: $A, B, C$ (Cədvəl 3.3). A grupu xəstələrdə göstəricilər normal səviyyədədirlər və bu qrupa normal qaraciyərlər və ya kompensasiya dövründə olarn sirrozlar aid edilir. A qrupundakı xəstələrdə böyük həcmli rezeksiyalar $(>50 \%)$ aparıla bilir. $B$ qrupu xəstələrdə subkompensasiya səviyyəsindəki qaraciyər yetməzliyi olan xəstələr aid edilir və bu xəstələrdə kiçik həcmli $(<30 \%)$ rezeksiyaların aparılması məsləhət görülür. $C$ qrupu xəstələrdə isə qaraciyər yetməzliyi dekompensasiya səviyyəsində olduğu üçün rezeksiya əks göstəriş sayılır. Sadə və praktik olduğu üçün geniş yayılmasına baxmayaraq, Child təsnifatının dəqiq olmadığını göstərən faktlar vardır. B və $\mathrm{C}$ dərəcəli sirrozlarda böyük həcmli rezeksiyalar aparıla bildiyini və A dərəcəlilərdə isə qaraciyər rezeksiyası baş verdiyini göstərilir.

Cadval 3.3

Child təsnifatına görə sirrozun ağırlıq dərəcələri

\begin{tabular}{|l|c|c|c|}
\hline \multirow{2}{*}{ Göstoricilar } & \multicolumn{3}{|c|}{ Sirrozun ă̆ırlıq dorəcəlori } \\
\cline { 2 - 4 } & $\boldsymbol{A}$ & $\boldsymbol{B}$ & $\boldsymbol{C}$ \\
\hline Bilirubin (mkmol/l) & $<34,2$ & $34,2-51,3$ & $>51,3$ \\
mg/dl & $<2$ & $2-3$ & $>3$ \\
Albumin (g/l) & $>35$ & $30-3,5$ & $<30$ \\
Assit & Yox & Müalicəyə asan & Müalicəyə çətin \\
& & tabe olur & tabe olur \\
Nevroloji pozulmalar & Yox & Minimal & Ciddi, koma \\
Qidalanma & Yaxş1 & Orta & Arıqlama \\
\hline
\end{tabular}


Xolinesteraza qaraciyərdə sintez olunan fermentdir və onun səviyyəsinə görə qaraciyərin sintetik funksiyası qiymətləndirilir. $\mathrm{Bu}$ üsul daha çox transplantasiyada köçürülən qaraciyərin funksional vəziyyətini tə’yin etmək üçün istifadə edilir.

Yükləmə sınaqlarında ekzogen maddələrin qandan qaraciyər vasitəsi isə təmizlənməsinə görə zərərsizləşdirmə (bromsulfalein , indosianin yaş1, amidopirin, lidokain və s.), və energetik (qalaktoza və s.) funksiyalarının ehtiyatları müəyyən edilir.

Bromsulfalein sınağı allergik reaksiyalar törətdiyi üçün hazırda geniş istifadə edilmir. Amidopirin, lidokain, qalaktoza sınaqları geniş yayılmamışdır.

Yükləmə sınaqları arasında indosianin yaşıl sınăğ (İSYS) ən geniş yayılanıdır. ISY qandan sür'ətli şəkildə qaraciyər tərəfindən tutulur və heç bir biotransformasiyaya uğradilmadan öd yollarına atılır. Bromsulfaleindən fərqli olaraq İSY entero-hepatik dövrana daxil olmur. Xəstəyə vena daxilinə $0,5 \mathrm{mg} / \mathrm{kg}$ dozada İSY vurulur və $15 \mathrm{dəq}$. sonra qan alınaraq birbaşa və ya qulaqda fotometrik üsulla boyanın miqdarı ölçülür. Sınağı müxtəlif dövrlərdə təkrarlayaraq "İSY indeksini"- nisbətləri də istifadə oluna bilər. Normada 15 dəq. sonra İSY qandakı miqdarı başlanğıcdakı səviyyəsinin 10\%-dən azını təşkil edir. Boyanın qandan təmizlənmə vaxtının uzanması, yəni retensionunun 10\%-dən artıq olması qaraciyərdə qan dövranının pozulmasını, hepatosellülar yetməzliyi göstərir. İSY-1n 15-ci dəqiqədəki indeksi (ISYİ ${ }_{15}$ ) 10\%-dən az olan hallarda böyük rezeksiyaların aparılması, 10-20\% arasında olduqda kiçik həcmli rezeksiyaların aparılması, 20\%-dən çox olduqda isə heç bir rezeksiya aparılmaması məsləhət görülür. Lakin, yükləmə sınaqları bir funksiyanı göstərdikləri üçün qaraciyər funksiyasını tam əhatə etmirlər. Bə’zi tədqiqatlarda İSYİ ${ }_{15} 20 \%$-dən yüksək olan hallarda böyük rezeksiyalar aparıldığg bildirilir.

Bə’zi tədqiqatçılar Child və İSYİ birlikdə istifadə edirlər.

Həm Child, həm də yükləmə sınaqlarında ümumi əksik cəhət odur ki , qaraciyərin həcmi ilə funksiyası arasındakı asılılıq təxmini olraq tə’yin edilir. Bunu nəzərə alaraq daha obyektiv üsul olan əməliyyatdaxili indosianin yaşıl sınağı (ODİSYS) tərəfimizdən təklif edilmişdir. 
Qaraciyar rezeksiyasına göstorişlor va oks göstorişlor

Oməliyyatdaxili indosianin yaşı1lı indeksi böyük və orta həcmli qaraciyər rezeksiyalarının planlanmasında istifadə edilir. Oməliyyatdan öncə 10-cu dəqiqədə indosianinin qandan təmizlənmə göstəricisi hesablanır. Oməliyyat vaxtı çıxarılması nəzərdə tutulan payın qapı elementlərinə sıxac qoyulur və xəstənin venasına $0,5 \mathrm{mg} / \mathrm{kg}$ dozada indosianin yaşı1 boyası vurulur. Boya verildikdən öncə və 1, 3, 5, 7, 10 dəq. sonra qanda boyanın konsentrasiyas1 ölçülür. Bu göstəricilərə əsasən portal elementlərin birtərəfli sıxıldığı halda boyanın 10-cu dəqiqədəki təmizlənmə faizi hesablanır. Oməliyyatdan öncə 10-cu dəqiqədəki təmizlənmə göstəricisinin, portal elementlərin birtərəfli s1xılmasından sonra 10-cu dəqiqədəki təmizlənmə göstəricisinə olan nisbəti hesablanır. $\mathrm{Bu}$ nisbətin 3-dən çox olması, qalan qaraciyərin funksiyonal rezervlərinin çox az olduğunu, qaraciyər funksiyasının 3 dəfədən çox azldığını və əməliyyatdan sonrakı dövrdə qaraciyər yetməzliyi baş vermə ehtimalının yüksək olduğunu göstərir. $\mathrm{Bu}$ xəstələrdə sıxac qoyulmuş bölgənin çıxarılması məsləhət deyildir. Rezeksiya həcmini azaltmaq və ya rezeksiya etməmək lazımdır. İndeksin qiyməti 2-3 arasında dəyişərsə kiçik həcmli rezeksiyalar - seqmentektomiyalar aparıla bilər. Omiliyyatönü/ əməliyyatdaxili təmizlənmə nisbətinin 2-dən kiçik olduğu hallarda s1xac qoyulmuş bölgənin çıxarılması- lobektomiya və genişləndirilmiş lobektomiyalar mümkündür.

Beləliklə, qaraciyrərin rezektabelliyini tə’yin tmək üçün rezeksiya həcmi, qaraciyərin funksional ehtiyatları və qaraciyərin funksional yükunü artıran amilləri müəyyən etmək lazımdır. Qaraciyərin funksional ehtiyyatlarını tə’yin etmək üçün obyektiv üsul olan əməliyyatdaxili indosianin yaşıl indeksi hesablana bilər. Bunun tətbiq edilməsi mümkün olmadıqda klassik Child təsnifatı istifadə edilə bilər. $\mathrm{Bu}$ üsulları qiymətləndirərkən aşağıdakı mə'lumatların nəzərə alınması tövsiyə olunur.

Lobektomiya vo genişlandirilmiş lobektomiyaya (böyük hacmli rezeksiyalara) göstorişlar

- Normal qaraciyər

- ODİSY indeksi <3

- Bilirubin $<2 \mathrm{mg} / \mathrm{dl}$ 
- Albumin $>3,5 \mathrm{q} / \mathrm{dl}$

- Müvəqqəti, müalcə olunan assit

- İndosianin yaş1 $1_{15}<10 \%$

Seqmentektomiyalara (kiçik hacmli rezeksiyalara) göstərişlər:

- Normal qaraciyər

- ODİSY indeksi 2-3

- Bilirubin 2-3 mg/dl

- Albumin 3-3,5q/dl

- Müvəqqəti, müalicə olunan assit

- İndosianin yaş1 $1_{15} 10-15 \%$

Rezeksiyaya əks göstərişlar:

- Kəskin hepatit

- Hepatik koma

- ODISSY indeksi $>3$

- Bilirubin $>3 \mathrm{mg} / \mathrm{dl}$

- Albumin $<3 \mathrm{q} / \mathrm{dl}$

- Refrakter assit

- ALT və ya AST >100 TV/L

- İndosianin yaş1 $1_{15}>15 \%$

\section{Bölümün yekunu}

Qaraciyər rezeksiyası ağır və travmatik əməliyyatlardan biri olub, ağırlaşma halları yüksək olan müalicə metodudur. Ona görə də, rezeksiya qərarını verərkən bu əməliyyatın törədə bildiyi ağırlaşmalar və müalicə effekti nəzərə alınmalıdır. Qaraciyər rezeksiyası qərarını vermək üçün üç məsələ ciddi və obyektiv bir şəkildə həll edilməlidir.

1. Xostalik rezektabeldirmi?

2. Qaraciyor rezektabeldirmi?

3. Xosto rezektabeldirmi? 
Xəstəlik rezektabelliyi dedikdə, qaraciyərdə olan patoloji mənbənin çıxarılmasının lazım olub-olmadığı, texniki olaraq mümkün olması və xəstənin bundan fayda görməsi məsələləri nəzərdə tutulur. Xəstəliyin rezektabelliyini müəyyən edən amil xastaliyin təbiati va yayılma dəracasidir. Başqa sözlə, xəstəliyin təbiəti rezeksiyaya göstərişi müəyyən edirsə, yayılma dərəcəsi isə əks göstərişi müəyyən edir. Müalicəsi cərrahi əməliyyat tələb edən xəstəliklər adətən qaraciyərdə yer tutan toxumalı və ya kist şəkilli törəmələrdir. Bəd və xoş xassəli şişlər, parazitar və qeyri-parazitar kistlər, travma və xəstəlik nəticəsində nekrozlaşmış toxumalar qaraciyər rezeksiyasına göstəriş təşkil edən başlıca xəstəliklərdir.

Xəstəlik qaraciyərdə geniş yayıldıqda, ətraf orqanlara, və ya böyük damarlara sirayət etdikdə çıxarılması texniki çətinlik törətdiyi, ağırlaşma riskini artırdığı üçün rezeksiyaya əks göstəriş sayılır. Uzaq metastazlar da rezeksiyaya əks göstərişdir, çünki, xəstəlik mənbəyinin çıxarılmasının xəstəyə faydası olmur. Klinik olaraq, aşağıdakı hallar xəstəliyin rezektabel olmadığını göstərir, yə’ni rezeksiyaya əks göstəriş kriteriyaları sayılırlar:

1. Hor iki paya yayılma

2. Böyük damarlara invaziya

3. Otraf orqanlara invaziya

4. Uzaq metastaz

Belalikla, xastaliyin təbiati müəyyən edildikdən sonra, rezeksiyaya aks göstวriş kriteriyaları araşdırılır. Oks göstəriş kriteriyaları olmayan xastalik rezektabel qa'bul edilir.

Xəstəliyin rezektabelliyinə qərar verildikdən sonra ikinci məsələnin - qaraciyərin rezektabelliyi məsələsinin həllinə keçilir. Qaraciyərin rezektabelliyi dedikdə, xəstənin qaraciyərinin planlanan rezeksiyaya davam gətirib-gətirməyəcəyi, başqa sözlə, "qaraciyərin planlanan hissəsi çıxarıldıqdan sonra qalan hissə kompensasiya və regenerasiya edərək funksiyasını bərpa edəcəkmi ?" məsələsi nəzərdə tutulur. Böyük həcmli rezeksiyalarda (50\%-dən çox) bu məsələnin həlli qaraciyər cərrahiyyəsinin ən aktual problemlərindən biridir və bu günə qədər dəqiq həll edilməmişdir.

Qaraciyərin rezektabelliyi məsələsinin həlli üçün şübhəsiz ki, qaraciyərin qalan hissəsinin funksional ehtiyatlarını dəqiq bilmək lazımdır. 
Mövcud üsullar empirik olub, qaraciyərin hazırkı funksional vəziyyətinə və rezeksiya həcminə əsaslanır.

Normal qaraciyər $75-80 \%$ rezeksiyaya davam gətirə bilir. Ona görə də, bu səviyyə normal qaraciyərdə aparılan rezeksiyaların üst həddi sayılır.

Parenxima xəstəliyi olan hallarda rezektabelliyi müəyyən etmək üçün müxtəlif funksional sınaqlar və göstəricilər nəzərə alınır. On çox istifadə edilən üsullar İSY sınağı və Child təsnifatıdır. Biz təcrübəmizdə əməliyyatdaxili indosianin yaşıl sınağından istifadə edirik ${ }^{1}$. Ogər çıxarılması nəzərdə tutulan qaraciyər parçasının qan dövranı kəsildikdən sonra İSY-ın təmizlənmə dərəcəsi 3 dəfədən çox azalarsa rezeksiya əks göstəriş sayılır. $\mathrm{Bu}$ halda ya rezeksiya aparılmamalıdır, ya da rezeksiya həcmi kiçildilməlidir. İndeksin qiyməti 2-3 arasında dəyişərsə kiçik həcmli rezeksiyalar seqmentektomiyalar aparıla bilər. Təmizlənmə dərəcəsi 2 dəfədən az dəyişərsə, lobektomiya və genişləndirilmiş lobektomiyalar aparıla bilər. Oməliyyatdaxili indosianin yaşıl sınağı aparmaq imkanı olmayan hallarda Child təsnifatından istifadə edilməsi məsləhət görülür. Xəstədə aşağıdakı kriteriyalar biri olduqda rezeksiya əks göstəriş sayılır:

1. Bilirubin $>3 \mathrm{mg} / \mathrm{dl}$

2. Albumin $<3 \mathrm{q} / \mathrm{dl}$

3. Refrakter assit

4. ALT və ya AST $>100 \mathrm{TV} / \mathrm{L}$

5. İndosianin yaş1 $1_{15}>15 \%$

Üçüncü məsələ - xəstənin rezektabelliyi və ya operabelliyi, yə’ni xəstənin orqan və sistemlərinin qaraciyər rezeksiyası kimi ağır və travmatik aməliyyatın stresinə davam gatirə bilməsi məsələsidir. Bu məsələ ümumi qayda üzrə həll edilir, yə’ni xəstənin qan dövranı, tənəffüs, ifrazat koaqulyasiya, sistemlərinin vəziyyəti və rezeksiyanın ağır əməliyyat olduğu nəzərə alınır. Ümumiyyətlə, həyati vacib orqan və sistemlərdəki yetməzlik, diğər ağır əməliyyatlar kimi, qaraciyər rezeksiyasına da əks göstəriş sayılır.

Beləliklə, qaraciyər rezeksiyasına göstəriş və əks göstərişləri aşağıdakı şəkildə göstərmək olar (Şəkil 3.16).

\footnotetext{
${ }^{1}$ bu haqda ətraflı mə’lumat “Oməliyyatdaxili diaqnostika” bölümündə verilmişdir.
} 
Rezeksiyaya wks-göstwriplwr

•Hwr iki paya yayyma
•Böyük damarlara invaziya
- Wraf orqanlara invaziya
-Uzaq metastaz
-Murkuzi böyük kistlur

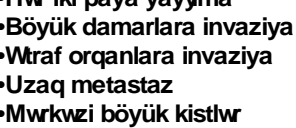

Böyük damarlara invaziya

Wraf orqanlara invaziya

Mwrkwzi böyük kistlu

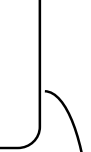

\section{XWSTWLIYIN}

rezektabelliyi

(xustwiyin twbinti vw

yayýma dwrwcusi)

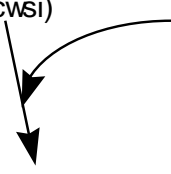

Qeyri rezektabel

\section{REZEKTABEL}

Rezeksiyaya göstwriplwr

•I,Il dövrduki birincili bud xasswi piplur

- Íkin munbuyi çx́xaryımy, ekstrahepatik yayylýmý

olmayan metastatik piblwr

-Simptomatik xop xasswi

piplwr

-Periferik kistlur

-Neoplastik kistlur

-Tuktwrufli Karoli zustwiyi

-Qaraciyur köçürülmusi

-Xronik abses

-IV durwculi travma

-Kuskin hepatit
-WDŚSY indeksi >3
-Hepatik koma
-Bilirubin $>3 \mathrm{mg} / \mathrm{dl}$
-Albumin $<3 \mathrm{q} / \mathrm{dl}$
-Refrakter assit
-ALT vwya AST $>100 \mathrm{TV} / \mathrm{L}$
-Ýndosianin yaby $>15 \%$

Qeyri rezektabel

-Normal qaraciywr -WDÉSY indeksi $<3$

-Xronik hepatit

-Bilirubin <3 mg/dl

-Albumin $>3 q / d l$

- Müvnqquti assit

-Ýndosianin yapy <15\%

rezeksiya hwcmi

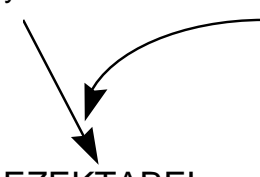

REZEKTABEL

-Qan dövranýyetmuzliyi
-Tunuffis yetmuzliyi
•Böyruk yetmuzliyi
- Ýmmun yetmuzlik
-Adýr laxtalanma
pozulmalarý
-Adýr anemiyalar
-Sepsis
-Koma
-Wmuliyyat önü hazýrlýq vaxtý
müalicwedilmwyun
pozulmalar

Qeyri rezektabel

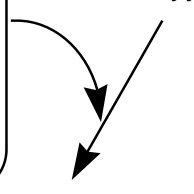

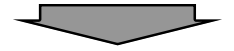

\section{XWSTWN'́}

rezektabelliyi

(ümumi vwziyywt vw wmwlyyatönü hazýrlýq)

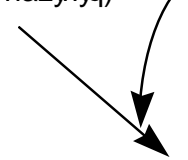

REZEKTABEL

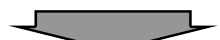

REZEKSÝYA
- Normal vuziyyut

- Sistemik xwstulik yox -Wmwliyyat önü

hazýlýqqda müalicw edilun pozulmalar

Şəkil 3. 16. Qaraciyər rezeksiyasına göstoriş vo əks göstorişlər 


\section{ӘDӘВIYYAT}

\section{QARACIYOR KISTLORI}

1. Akoğlu M., Davidson BR. A rational apporach to the trminology of hydatid disease of the liver. J infection 1992:24:1-6

2. Catinis GE, et al. Hepatic cystadenoma: an unusual presentation. Am J Gastroenterol. 1998 May;93(5):827-9.

3. Domene CE, et al. Videolaparoscopic treatment of hepatic single cysts. Rev Hosp Clin Fac Med Sao Paulo. 1997 Nov-Dec;52(6):302-5.

4. Doty JE., Tompkins RK. Management of cyctic diseasees of the liver. In. Surg Cln North Am 1989:69:2:285-296

5. Frey CF et al. Liver abscesses. In. Surg Cln North Am 1989:69:2:259-272

6. Horejsova M, et al. Epithelioid hemangioendothelioma of the liver. Accidental detection of a solitary focus resembling a hepatic cyst. Cas Lek Cesk. 1998 Aug 3;137(15):476-8.

7. Kesby GJ. Pregnancy complicated by symptomatic adult polycystic liver disease. Am J Obstet Gynecol. 1998 Jul;179(1):266-7.

8. Klingler PJ, et al. Late complication after laparoscopic fenestration of a liver cyst. Surg Laparosc Endosc. 1998 Feb;8(1):76-7.

9. Konoshita $\mathrm{T}$, et al. Clinical characteristics of polycystic kidney disease əith end-stage renal disease. The Kanazaəa Renal Disease Study Group. Clin Nephrol. 1998 Aug;50(2):113-7.

10. Koperna T, et al. Nonparasitic cysts of the liver: results and options of surgical treatment. Oorld J Surg. 1997 Oct;21(8):850-4; discussion 854-5.

11. Langer B., Gallinger S. Cystic diseases of liver. In: Shackelfrd's Surgery of the alimentary tract.Saunders Company, 1996:526-563

12. Suzuki F, et al. Intracystic hemorrhage of simple hepatic cyst--report of a case. Nippon Shokakibyo Gakkai Zasshi. 1998 Aug;95(8):926-8. 
13. Tzen CY, et al. Mesenchymal hamartoma of the liver: a case report. Chung Hua I Hsueh Tsa Chih (Taipei). 1998 Jul;61(7):427-31..

\section{HEPATOSELLULAR XəRÇӘNG}

1. Billingsley KG, et al. Segment-oriented hepatic resection in the management of malignant neoplasms of the liver. J Am Coll Surg. 1998 Nov;187(5):471-81.

2. Farges $\mathrm{O}$, et al. Surgical treatment of hepatocellular carcinoma in cirrhosis. Ann Chir. 1998;52(6):535-42. Revieə. French.

3. Farges $\mathrm{O}$, et al. Aggressive management of recurrence folloəing surgical resection of hepatocellular carcinoma. Hepatogastroenterology. 1998 Aug;45 Suppl 3:1275-80.

4. Farmer DG, Rosove MH, Shaked A, Busuttil RӘ. Current treatment modalities for hepatocellular carcinoma. Annal.Surgery 1994;219(3):236-247

5. Hemming AӘ, et al. Aggressive Surgical Management of Fibrolamellar Hepatocellular Carcinoma. J Gastrointest Surg. 1997 Jul;1(4):342-346.

6. Kimura $\mathrm{H}$, et al.Prognostic factors in resected hepatocellular carcinomas and therapeutic value of transcatheter arterial embolization for recurrences. Int Surg. 1998 Apr-Jun;83(2):146-9.

7. Lam CM, et al. Prolonged survival in selected patients folloəing surgical resection for pulmonary metastasis from hepatocellular carcinoma. Br J Surg. 1998 Sep;85(9):1198-200.

8. Mazziotti A, et al. Surgical treatment of hepatocellular carcinoma on cirrhosis: a Oestern experience. Hepatogastroenterology. 1998 Aug;45 Suppl 3:1281-7.

9. Makuuchi M, et al. Hepatic resection for hepatocellular carcinoma -- Japanese experience. Hepatogastroenterology. 1998 Aug;45 Suppl 3:1267-74..

10. Olthoff KM. Surgical options for hepatocellular carcinoma: resection and transplantation. Liver Transpl Surg. 1998 Sep;4(5 Suppl 1):S98-104.

11. Rivas MJ, et al. Expression of human macrophage metalloelastase gene in hepatocellular carcinoma: correlation əith angiostatin generation and its clinical significance. Hepatology. 1998 Oct;28(4):986-93.

12. Rose AT, et al. Hepatocellular carcinoma outcomes based on indicated treatment strategy. Am Surg. 1998 Dec;64(12):1128-34; discussion 1134-5. 
13. Ryu M, et al. Hepatectomy əith microəave tissue coagulation for hepatocellular carcinoma. J Hepatobiliary Pancreat Surg. 1998;5(2):184-91..

14. Sbai Idrissi MS, et al. Treatment of hepatic recurrence after resection of hepatocellular carcinomas. Ann Chir. 1998;52(6):543-6.

15. Shirabe K, et al. Clinicopathologic features of patients ith hepatocellular carcinoma surviving >10 years after hepatic resection. Cancer. 1998 Dec 1;83(11):2312-6.

16. Shimada R, et al. Staged hepatectomy after emergency transcatheter arterial embolization for ruptured hepatocellular carcinoma. Surgery. 1998 Sep;124(3):526-35.

17. Takayama $\mathrm{T}$, et al. Early hepatocellular carcinoma as an entity əith a high rate of surgical cure. Hepatology. 1998 Nov;28(5):1241-6.

18. Tang ZY, et al.Progress and prospects in hepatocellular carcinoma surgery. Ann Chir. 1998;52(6):558-63.

\section{XOLANGIOKARSINOMA}

1. Blumgart LH., Benjamin İS. Liver resection for bile duct cancer. In. Surg Cln North Am 1989:69:2:323-338

2. Endo I, et al. Hepatic resection for advanced carcinoma of the gallbladder. Nippon Geka Gakkai Zasshi. 1998 Oct;99(10):711-6. Japanese.

3. Harrison LE, et al. Surgical treatment of 32 patients aith peripheral intrahepatic cholangiocarcinoma. Br J Surg. 1998 Aug;85(8):1068-70.

4. Iəatsuki S, et al. Treatment of hilar cholangiocarcinoma (Klatskin tumors) əith hepatic resection or transplantation. J Am Coll Surg. 1998 Oct;187(4):358-64.

5. Madariaga JR, et al. Liver resection for hilar and peripheral cholangiocarcinomas: a study of 62 cases. Ann Surg. 1998 Jan;227(1):70-9.

6. Nozaki $\mathrm{Y}$, et al. Reconsideration of the lymph node metastasis pattern ( $\mathrm{N}$ factor) from intrahepatic holangiocarcinoma using the International Union Against Cancer TNM staging system for primary liver carcinoma. Cancer. 1998 Nov 1;83(9):1923-9

7. Ogura Y, et al. Central bisegmentectomy of the liver plus caudate lobectomy for carcinoma of the gallbladder. Dig Surg. 1998;15(3):218-23.

8. Roayaie S, et al. Aggressive surgical treatment of intrahepatic cholangiocarcinoma: predictors of outcomes. J Am Coll Surg. 1998 Oct;187(4):365-72. 
9. Sasaki A, et al. Intrahepatic peripheral cholangiocarcinoma: mode of spread and choice of surgical treatment. Br J Surg. 1998 Sep;85(9):1206-9.

10. Yamamoto $\mathrm{M}$, et al. Does gross appearance indicate prognosis in intrahepatic cholangiocarcinoma? J Surg Oncol. 1998 Nov;69(3):162-7.

\section{METASTATIK QARACIYYR ŞIŞLӘRI}

1. Bakalakos EA, et al. Determinants of survival folloəing hepatic resection for metastatic colorectal cancer. Oorld J Surg. 1998 Apr;22(4):399-404; discussion 404-5.

2. Elias D, et al. Results of 136 curative hepatectomies oith a safety margin of less than $10 \mathrm{~mm}$ for colorectal metastases. J Surg Oncol. 1998 Oct;69(2):88-93.

3. Elias D, et al. Resection of liver metastases from a noncolorectal primary: indications and results based on 147 monocentric patients. J Am Coll Surg. 1998 Nov;187(5):487-93.

4. Fong Y, et al. Hepatic colorectal metastasis: current status of surgical therapy. Oncology (Huntingt). 1998 Oct;12(10):1489-98; discussion 1498-500, 1503.

5. Gibbs JF, et al. Intraoperative determinants of unresectability for patients əith colorectal hepatic metastases. Cancer. 1998 Apr 1;82(7):1244-9

6. Hanazaki K, et al. Hepatic metastasis from esophageal cancer treated by surgical resection and hepatic arterial infusion chemotherapy. Hepatogastroenterology. 1998 Jan-Feb;45(19):201-5.

7. Kato T, et al. Recent management of metastatic colorectal cancer. Gan To Kagaku Ryoho. 1998 Oct;25(12):1865-72.

8. Kevin H. et al. Surgery for colorectal cancer metastatic to liver. In. Surg Cln North Am 1989:69:2:339-360

9. Kokudo N, et al. Effects of systemic and regional chemotherapy after hepatic resection for colorectal metastases. Ann Surg Oncol. 1998 Dec;5(8):706-12.

10. Nakamura S, et al. Resection of metastatic liver tumors oith special reference to hepatic venous system. Hepatogastroenterology. 1998 Jan-Feb;45(19):24-8.

11. Norton JA, et al. Surgical treatment of localized gastrinoma oithin the liver: a prospective study. Surgery. 1998 Dec;124(6):1145-52 
12. Purkiss SF. Theoretical evaluation of measurements used to assess the groath of colorectal hepatic metastases. Eur J Surg. 1998 Nov;164(11):803-9.

13. Quinlan RM. Tumors of the liver. In: Shackelfrd's Surgery of the alimentary tract.Saunders Company, 1996:512-525

14. Robinson $\mathrm{BJ}$, et al. Is resection of pulmonary and hepatic metastases əarranted in patients aith colorectal cancer? J Thorac Cardiovasc Surg. 1999 Jan;117(1):66-76.

15. Zibari GB, et al. Surgical and nonsurgical management of primary and metastatic liver tumors. Am Surg. 1998 Mar;64(3):211-20; discussion 220-1.

\section{QARACIYYRIN XOŞ XASSOLI ŞISSLORI}

1. Bartolozzi C, et al. Differentiation of hepatocellular adenoma and focal nodular hyperplasia of the liver: comparison of poəer Doppler imaging and conventional color Doppler sonography. Eur Radiol. 1997;7(9):1410-5.

2. Beets-Tan RG, et al. Hepatic adenoma and focal nodular hyperplasia: MR findings aith superparamagnetic iron oxide-enhanced MRI. Clin Imaging. 1998 MayJun;22(3):211-5.

3. Broglia L, et al. Computerized tomography, magnetic resonance, and nuclear medicine in the non-invasive diagnosis of focal nodular hyperplasia of the liver. Radiol Med (Torino). 1998 Sep;96(3):218-25

4. Cohen C, et al. Sex and androgenic steroid receptor expression in hepatic adenomas. Hum Pathol. 1998 Dec;29(12):1428-32.

5. Francis C et al. Benign liver tumors. In. Surg Cln North Am 1989:69:2:297-314

6. Fukukura Y, et al. Angioarchitecture and blood circulation in focal nodular hyperplasia of the liver. J Hepatol. 1998 Sep;29(3):470-5.

7. Lopez Cano A, et al. Focal nodular hyperplasia: characterization əith Doppler ultrasonography. Gastroenterol Hepatol. 1998 Jun-Jul;21(6):277-9.

8. Mergo PJ, et al. MRI in focal liver disease: a comparison of small and ultra-small superparamagnetic iron oxide as hepatic contrast agents. J Magn Reson Imaging. 1998 Sep-Oct;8(5):1073-8.

9. Ott R, et al. Focal nodular hyperplasia and liver cell adenoma: operation or observation? Zentralbl Chir. 1998;123(2):145-53 
Qaraciyor rezeksiyasına göstorişlor va oks göstorişlor

10. Sakamoto M, et al. Natural history and prognosis of adenomatous hyperplasia and early hepatocellular carcinoma. Jpn J Clin Oncol. 1998 Oct;28(10):604-8.

11. Turkenburg JL, et al. Focal nodular hyperplasia. J Belge Radiol. 1998 Oct;81(5):249.

\section{QARACIYOR TRAVMALARI}

1. Moore E.E. Critical Decisions in the Management of Hepatic Trauma. Am J Surg 148: 712-717, 1984

2. Feliciano DV, Jordan GL, Bitondo CG et al. Management of 1000 Consecutive Cases of Hepatic Trauma. Ann Surg 204: 438-445, 1986

3. Feliciano DV, Burch JM, Spjut-Patrinely V et al. Abdominal Gunshot Đounds. Ann Surg 208: 362-369, 1988

4. Đalker ML, Poindexter JM, Stovall I. Principles of Management of Shotgun əounds. Surg Gynecol Obstet 170: 01-05, 1990;

5. Feliciano DV. Surgery for Liver Trauma. Surg Clinic North Am 69: 273-284, 1989

6. Юароюnikov VV. Diaqnostika i leзenie raneniy. Moskova 1985

7. Bayramov NY. Odlu silah yaralanmalarının patogenezi və müalicə prinsipləri. Bakı 1994.

8. Bayramov NY. Classification Of Gunshot Đounds Of The Liver. East J Surg 1996:2:80-85

9. Bruce A., Cairns MD, Dale Э. et al. Management and Outcome of Abdominal Shotgun Đounds. Ann Surg. 221: 272-277, 1995

10. Grimes ӘR, Deitch EA, McDonald JC. A Clinical Revieə of Shotgun Đuonds to the Chest and Abdomen. Surg Gynecol Obstet 160: 148-152, 1985

11. Glezer JA, Minard G, Groce MA. Shotgun Đounds to the Abdomen. Am Surg. 59: 129-132, 1993

12. Reed RL, Merrell RC, Meyers $ə C$ et al. Continuing Evolution in the Approach to Severe Liver Trauma. Ann. Surg 216: 524-538, 1992

13. Pachter HL, Spencer FC, Hofstetter SR et al. Significant Trends in the Treatment of Hepatic Trauma. Ann Surg 215: 492-502, 1992 
14. Degiannis E, Levy RD, Velmahos GC, et al. Gunshot injuries of the liver: The Baragəanath experience. Surg 117: 359-364, 1995

15. Moore EE, Shackford SR, Pachter HL. et al. Organ injury scaling: spleen, liver and kidney. J Trauma 29: 1664-1666

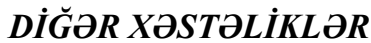

1. Chen YS, et al. Pediatric liver transplantation from living-related donors. Transplant Proc. 1998 Nov;30(7):3252-3

2. Chan FL, et al. Modern imaging in the evaluation of hepatolithiasis. Hepatogastroenterology. 1997 Mar-Apr;44(14):358-69

3. HABERAL M. Organ ve doku transplantasyonları.1994

4. Jeng KS. Treatment of intrahepatic biliary stricture associated əith hepatolithiasis. Hepatogastroenterology. 1997 Mar-Apr;44(14):342-51

5. Kaəagishi N, et al. Safety of the donor operation in living-related liver transplantation: analysis of 22 donors. Transplant Proc. 1998 Nov;30(7):3279-80

6. Kelly DA. Pediatric liver transplantation. Curr Opin Pediatr. 1998 Oct;10(5):493-8

7. Liu CL, et al. Primary biliary stones: diagnosis and management. Đorld J Surg. 1998 Nov;22(11):1162-6

8. Miyagaəa S, et al. Concomitant caudate lobe resection as an option for donor hepatectomy in adult living related liver transplantation. Transplantation. 1998 Sep 15;66(5):661-3.

9. Oikaəa $\mathrm{K}$, et al. Graft əeight/recipient body əeight ratio (G/R ratio) in living-related liver transplantation for pediatric patients: abdominal əall closure in cases əith a large $G / R$ ratio.Transplant Proc. 1998 Nov;30(7):3209-10.

10. Taira K, et al. A neə, stable model of left lobectomy for living-related liver transplantation in the pig. Transplant Proc. 1998 Nov;30(7):3207-8. 
IV Bölüm

\section{QARACIYYRIN REZEKSIYYA ÜSULLARI}

\section{QARACIYOR REZEKSIYASININ TOSNIFATI}

Qaraciyər rezeksiyası əməliyyata göstərişə, əməliyyat ardıcıllığına, parenximanı kasmə üsuluna, çıxarılan parenxima hacminə, və rezeksiya edilan bölgənin adına görə təsnif edilir.

Göstərişin tə'cili olub olmadığına görə tə'cili və planlı rezeksiyalar ayırd edilir. Tə'cili rezeksiyalar az hallarda tətbiq edilir və travmalarda, şiş partlamaları və qanaxmalarda, mexaniki sarılıqda aparılır. Qaraciyərin əksər cərrahi xəstəliklərində isə, planlı rezeksiyalar daha çox yerinə yetirilir.

Omaliyyat ardıcılliğına görə təsnifatda parenxima və damar ayaqcığının kəsilib bağlanması ardıcıllığı nəzərdə tutulur. "Şərq üsulunda" əvvəlcə parenxima kəsilir, sonra isə, damar ayaqcıqlar bağlanıb kəsilir. "Qərb üsulunda" isə, bunun əksi - əvvəlcə ayaqciq sonra isə, parenxima kəsilir. "Qarışıq üsulda" isə, qapı ayaqcı̆̆ı bağlanıb kəsildikdən sonra parenxima kəsilir, ən axırda isə, qaraciyər venaları bağlanıb kəsilir.

Qaraciyər parenximasını kasmək üçün istifadə edilən üsullar prinsipial olaraq üç əsas grupa ayrılır: hemostatik tikiş qoyub kəsmə, dağlama və ayırma üsulları. Hemostatik qoyub kəsmə üsulu hazırda yalnız biopsiyalarda istifadə olunur. On çox ayırma üsulu istifadə olunur. Dağlama üsulları isə, ayırma üsuluna köməkci kimi tətbiq olunur.

Rezeksiya həcminə görə təsnifatında çıxarılan parçadakı sağlam parenximanın miqdarı nəzərdə tutulur $\mathrm{ki}$, bu da çıxarılan sağlam parenximanın qalan qaraciyərə nisbəti ilə ölçülür. Yə’ni, nə qədər sağlam qaraciyər parenximası çıxarıldığı müəyyənləşdirilir. $\mathrm{Bu}$ əslində qalan 
qaraciyərin funksional yükünü qiymətləndirmək deməkdir. Törəmənin həcmi nəzərə alınmır, çünki, törəmələr adətən qeyri-funksional hesab edilir. Rezeksiya həcminə görə böyük, orta və kiçik rezeksiyalar ayırd edilir. Parenximanın 30\%-dən azının çıxarılması kiçik, 30-50\%-nin çıxarılması orta, 50\%-dən çoxunun çıxarılması isə, böyük həcmli rezeksiya adlanır. Parenximanın pezeksiya hacmi (PRH) qaraciyər parenximasının rezeksiya nəticəsində nə qədər azaldığını göstərir və aşağıdakı düsturla hesablanır:

$$
\boldsymbol{P R H}=\frac{\text { Çx́xaryan qaraciywr parçasýnýn hwcmi }- \text { Pipin hwcmi }}{\text { Qaraciywrin umwliyyatdan öncwhwcmi - Pipin hwcmi }} \boldsymbol{x} \mathbf{1 0 0}
$$

Parenximanın və rezeksiyanın həcmini tə'yin etmək üçün tomoqrafiya üsulu daha obyektivdir. Tomoqrafiya üsulu mümkün olmadıqda seqmentlərin təxmini həcminə görə hesablana bilər. I seqment qaraciyər həcminin 5\%-ni, II+III seqmentlər birlikdə - 15\%, IV seqment - 20\%, V, VI, VII və VIII seqmentlərin hər biri qaraciyər həcminin 15\%-ni təşkil edir. Onu qeyd etmək lazımdır ki, verilən seqment həcmləri normal qaraciyər üçün nəzərdə tutulmuşdur. Qaraciyər xəstəliklərində seqmentlər atrofiyaya və ya hipertrofiyaya uğrayaraq həcmlərini çox dəyişə bilir. Məsələn, sirrozda sol pay hipertrofiyaya uğrayaraq sağ pay həcminə yaxınlaşa, hətta keçə bilər. Bundan başqa, bir payı və ya segmenti tutan törəmələrdə qaraciyərin diğər bölgələri hipertrofiyaya uğrayaraq böyüyə bilirlər. Ona görə də, parenximanın rezeksiya həcmini qiymətləndirərkən tomoqrafik üsullara daha çox əhəmiyyət vermək lazımdır.

Çıxarılan bölgənin adına görə təsnifat ən çox qarışıqlıq törədən təsnifatdır. Eyni əməliyyat müxtəlif müəlliflər tərəfindən müxtəlif adlarla verilir və ya müxtəli həcmli rezeksiyalar eyni adla verilir. Məsələn, cərrahi sağ payın çıxarılması sağ lobektomi, sağ hepatektomi, sağ hemihepatektomi adlanır. Bu qarışıqlığın başlıca səbəbi köhnə anatomik nomenklatura ilə qaraciyarin həqiqi arxitektonikası arasındakı uyğunsuzluqdur. Köhnə anatomik nomenklaturada sağ və sol paylar arasındakı sərhəd oraqvari bağ hesab edilir. Həqiqətdə isə, paylar arasındakı sərhəd orta qaraciyər venası üzrədir. Yə’ni, köhnə nomenklaturada qaraciyərin xarici görünüşü nəzərdə tutulur. Ona görə də, klinik praktikada bunları ayırmaq üçün qaraciyərin xarici görünüşünə əsaslanan nomenklaturaya anatomik, daxili arxitektonikasına əsaslanan nomenklatura isə, cərrahi nomenklatura deyilir. 
Məsələn, anatomik sağ paya cərrahi sağ pay və IV seqmentdən təşkil olunmuşdur. Anatomik sol pay isə, cərrahi II+III seqmentlərə uyğun gəlir.

Bizim totbiq etdiyimiz təsnifatda qaraciyərin daxili arxitektonikasına əsaslanan cərrahi nomenklatura istifadə edilmişdir. Seqment ç1xarılması seqmentektomiya, sektor ç1xarılması sektorektomiya, cərrahi payın çıxarılması isə, lobektomiya və ya hemihepatektomiya adladırılır. Hepatektomiya terminini orqan köçürülməsində qaraciyərin bütövlükdə çıxarıldığg hallarda istifadə edirik.

Oməliyyatı adlandırarkən iki cəhəti qeyd etmək məsləhət görülür:

1. Çıxarllan bölgənin ümumi adı və ona daxil olan seqmentlor

2. Parenximanin rezeksiya hacmi

Misallar:

Qaraciyərin 2/3 rezeksiyası, sağ lobektomiya (hemihepatektomiya, V, VI, VII, VIII seqmentlər).

Qaraciyərin 35\% rezeksiyas1, sol lobektomiya (hemihepatektomiya - II, III, IV seqmentlər).

Qaraciyərin 55\% rezeksiyası, genişləndirilmiş sağ lobektomiya (VVIII+IV seqmentlər).

Klinik təcrübə və elmi araşdırmalar qaraciyər yetməzliyi, qanaxma, iltihabi proseslər və öd fistulları kimi ciddi ağırlaşmaların meydana gəlməsini parenximanın kəsilməsi vaxtı baş verən qanaxma, öd axarlarının yetərincə bağlanmaması, parenximanın nekrozu və qalıq qaraciyərin həcm və funksional baxımdan azlığı ilə əlaqələndirir. Oməliyyatdan sonrakı ağırlaşmalar içərisində ən çox rast gələni və müalicə nöqteyi-nəzərindən çətinlik yaradanı qanaxma və onun törətdiyi pataloji proseslərdir. 
Qaraciyorin rezeksiya üsullart

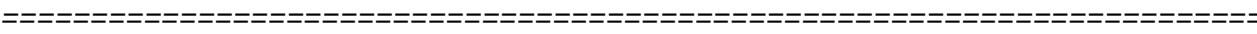

ŞWKil 4.1 QARACIYUR REZEKSIYASININ TUSNIFATI

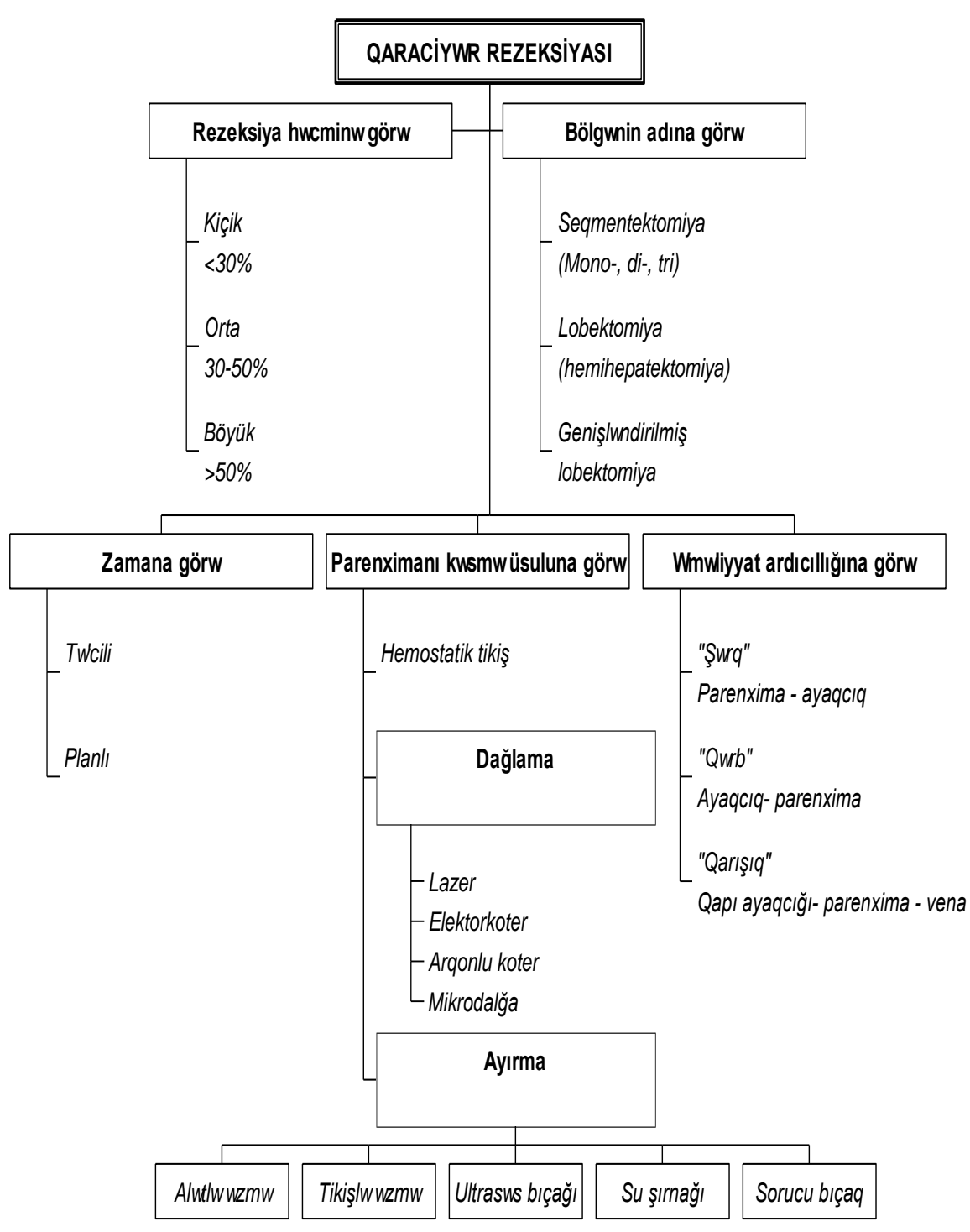


Qaraciyərin qanaxmaya yüksək dərəcədə meyilli olması parenximanın anatomik quruluşundan irəli gəlir. Quruluş baxımından qaraciyər arteriyaların, qapı venalarının və öd axarlarının təşkil etdiyi qapı strukturları və qaraciyər venalarından əmələ gəlmiş damar-axacaq torundan və parenxim hüceyrələrdən ibarətdir. Damar-axacaq torunun təşkilində pay, sektoral, seqmqntar, subseqmqntar, lobulyar və kapilyar damarlar və axacaqlar (sinusoidlər, mərkəzi venulalar, xolangiolalar) iştirak edir. Ölçüləri 20 mm-dən 7 mkm-ə qədər olan damar və axacaqların təşkil etdiyi bu tor makroskopik və mikroskopik səviyyələrdə yüksək sıxlığa malikdir və təxminən dəqiqədə $1500 \mathrm{ml}$ qanın qaraciyərdən keçməsini və $1000 \mathrm{ml} /$ gün miqdarında ödün ifrazını tə'min edir. Damar-axacaq torunun yüksək sıxlığı, yüksək dərəcədə qan təhcizatı $(1 \mathrm{ml} / \mathrm{g}$. dəq) və kapilyarlardan başlamış pay səviyyəsinə qədər bütün damarlardan qanaxma imkanının olması ilə əlaqədar parenximanın kəsilməsi vaxtı şiddətli qanaxma yaranır, vaxtında hemostaz edilmədikdə ağır qanitirmə ilə nəticələnir.

Ona görə də, parenximanın kəsilməsi vaxtı qanaxamanı dayandırmaq qaraciyər raezeksiyası əməliyyatının “özək nöqtəsini” təşkil edir. Başqa sözlə, qaraciyər parenximasının kəsilməsi aslində qaraciyərdaxili damar va axacaqların yetərli dərəcədə bağlanıb kəsilməsi deməkdir.

Hazırda qaraciyər rezeksiyalarında qanaxmanı dayandırmaq üçün müxtəlif metodlar istifadə edilməkdədir. Bu üsulları prinsipal olaraq iki qrupda cəmləşdirmək olar.

Birinci qrup üsullarda qaraciyərdə və ya onun kəsiləcək bölgəsində əvvəlcə qan axını dayandırıldırılır, sonra isə, parenxima kəsilir. "Hemostazkəsmə" adlandırdığımız bu üsullarda ya yerli sıxıcı tədbirlərin köməyi ilə (hemostatik tikişlərlə, sıxıcı alətlə) kəsik nahiyyəsində, ya da, magistral damarlara (qaraciyər arteriyası, qapı venası, qaraciyər venaları, pay damarları ) nəzarət etməklə bütün qaraciyərdə və ya bir payda qan axını dayandırılır, sonra isə, rezeksiya edilir. Rezeksiyadan sonra sıxıcı, büzücü tikişlərlə son hemostaz həyata keçirilir.

İkinci qrup üsullarda qanaxmanın dayandırılması parenximanın kəsilməsi vaxtı həyata keçirilir. "Kəsərkən hemostaz" adlandırdığımız bu qrupa damarların parenximlə birlikdə dağlanaraq (koaqulyasya edilərək) kəsilməsi (elektrik cərəyanı ilə, lazerlə, mikrodalğalarla, plazma ilə dağlama) 
və ya damar-axacaq elementlərini paraenximdən ayıraraq bağlanıb kəsilməsi (digitoklaziya-barmaqla ayırma, alətlə əzmə, tikişlə əzmə, şırnaqla ayırma, sorucu bıçaqla ayırma, ultrasəslə ayırma) üsulları aid edilir.

\section{QANAXMANI DAYANDIRMA ÜSULLARI}

Sıxıcı tikişlor qaraciyər rezeksiyasında istifadə edilən ən qədim üsullardandır. İlk qaraciyər rezeksiyası bu üsulla yerinə yetirilmişdir. Metodun əsasında tikişlərin parenximanı və damarları birlikdə sıxaraq kəsiləcək bölgədə qan axınını dayandırması durur. Bu məqsədlə müxtəlif tikiş növləri təklif edilmişdir: fasiləli “ " $"$ "şəkilli, “ $Z$ ” şəkilli, blok tikişlər; fasiləli döşək (matras) tikişi, çəkməçi tikişi, burmalı tikiş, qayıdan tikiş, metal, plastik tikişlər və s. Tikişlər kəsik xəttindən $1 \mathrm{sm}$ aralı qoyulduqdan sonra parenxima kəsilir. Kəsik səthində baş verən qanaxan yerlərə əlavə sıxıcı tikişlər və ya örtücü "Z”-şəkilli tikişlər qoyularaq qanaxma dayandırılır .

Texnik olaraq asan və əlavə vəsait tələb etməməsinə baxmayaraq bu üsulların bir çox əksik cəhətləri vardır. Qaraciyər parenximasında nekrozlaşma, əməliyyat vaxtı və əməliyyatdan sonrakı dövrdə qanaxmalar, öd fistulları tikiş üsulunda ən çox rast gələn ağırlaşmalardır. Qaraciyərdaxili damarlardakı təzyiqlər nəzərə alınarsa, tikişlə qanaxmanı dayandırmaq üçün ən az 20-25 mm Hg st. təzyiq yaratmq tələb olunur. Bu təzyiq isə, parenximanın əzilməsinə, tikişlərdən distal tərəfdə qalan $1 \mathrm{sm}$ enindəki toxumanın qan təchizatının pozulmasına və nəticədə tikiş xəttinə yaxın bölgələrdə parenximanın nekrozlaşmasına səbəb olur. Nekroza uğramış toxumalar əməliyyatdan sonrakı dövrdə intoksikasiya və septiki ağırlaşmalar törədə bilir. Bundan başqa nekrozlaşma tikişlərdə boşalma törədərək əməliyyatdan sonrakı dövrdə qanaxmaların və öd fistulların baş verməsinə səbəb ola bilr. Tikişlər vasitəsi ilə yüksək s1xıcı təzyiq yaratmaq mümkün olmadığ1 üçün (tikişlər parenximanı kəsir) təzyiqi $30-40 \mathrm{~mm} \mathrm{Hg}$ st. səviyəsindən artıq olan damarlardan, xüsusən subseqmentar, seqmentar və pay arteriyalarından qanaxmanın qarşısının alınmasında yetərsiz olur. Ona görə də, sıxıcı tikişlərdən istifadə edərək aparılan rezeksiyalarda intraoperasion qanaxmalar baş verir və onun dayandırılması üçün əlavə tikişlər qoymaq lazım gəlir. Bu səbəblərlə əlaqədar hazırda sıxıcı tikişlər qaraciyərin böyük həcimli rezeksiyalarında tətbiq edilmir. 
Sıxıcı alotlor vasitosi ilo rezeksiyalarda qaraciyər üçün hazırlanmış xüsus1 sıxıc1 ilə parenxima kəsik xəttininə yaxın yerdə müvəqqəti kompressiya edilərək kəsilir, kəsik səthinə tikişlər qoyularaq qanaxma dayandırılır, sonra alət çıxarılır. Mərkəzi və arxa seqmentektomiyalarda (IV, VII, VIII seqmentlər) bu üsulun tətbiqi texniki çətinliklər yaradır. Sıxıcı tikişlərə məxsus olan əksik cəhətlər bu üsulda da ortaya çıxdığından geniş tətbiq tapmamışdır.

Magistral damarların müvoqqati vo daimi bağlanması. Qaraciyərin böyük həcimli rezeksiyalarında, ağır və qanaxmalı travmalarında, qanın laxtalanma qabiliyyətində pozulmalar olan hallarda qanaxmanın azaltmaq üçün qapı damarlarını müvəqqəti olaraq sıxmaq lazım gəlir. Әdəbiyatda bu metod Pringler usulu adlandırılır (235). Pringler üsulu qaraciyər venalaından baş verən qanaxmaları nisbətən, qapı damarlarından baş verən qanaxmaları isə, kəskin olaraq azaldır. Ona görə də, bu üsul qaraciyər travmalarında qanaxma mənbəyinin qap1 damarları yoxsa qaraciyər venaları olduğunu tə’yin etmək üçün də istifadə edilir. Pringler usulunda işemiyanın müddəti ilə ələqədar müxtəlif fikirlər var. Bu üsulun 10-15 dəqiqə sıxma, 5 dəqiqə açma hərəkətlərinin təkrarlanması ilə istifadə edilməsi geniş yayılmışdır. Bir çox müəlliflər qap1 damarlarının 1 saata qədər sıxılmasının qaraciyər üçün təhlükəsiz olduğunu göstərirlər. Qaraciyərin işemiya-reperfuziya zədələnmələrinin profilaktikası üçün antioksidantlar və sitoprotektorlar təkilf edilir. Asan yerinə yetirilməsi, tə'cili vəziyyətlərdə istifadə oluna bilməsi, parenximanın istənilən kəsilmə üsulları ilə birlikdə tətbiq oluna bilməsi və travmalarda qanaxma mənbəyinin tə'yini üçün yararlı olması Pringler üsulunun üstün cəhətləridir. Ancaq bu üsulun mə'də bağırsaq sistemində venoz staz (göllənmə) yaratması, dövr edən qanın həcmini azaltmas1, parenximada işemiya törətdiyi üçün işemiyaya çox həssas olan qaraciyər sirrozlarında istifadə imkanının kəskin azalması və canlı donordan qaraciyər parçasının köçürülməsi əməliyatında istifadə oluna bilməməsi kimi əksik cəhətləri də mövcuddur. Həmçinin bu üsulla icra edilən rezeksiyalarda parenximanın kəsilməsindən sonra qanaxmanı son və davamlı dayandırmaq üçün tikişlərdən, dağlama üsullarından və lokal hemostatiklərdən istifadə edilməsi lazım gəlir və damarlar parenxima içərisinə qaçdığı üçün bu üsulların yerinə yetirilməsi çətinləşir, effektliliyi isə, azalır. Ona görə də 
hazırda Pringler üsulu qaraciyər rezeksiyalarında sərbəst şəkildə yox, köməkçi və ehtiyat vasitə kimi istifadə olunur.

Magistral damarlara nəzarət metodlarından biri də onların qaraciyər qapısında, parenxima içərisində və aşağı boş venaya açılan yerdə ayrılıb bağlanmasdır. Çıxarılan payın, sektorun və ya seqmentin gətirici və aparıcı damarları selektiv olaraq bağlandıqdan sonra parenxima kəsilir, baş verən qanaxmalar digər üsullarla dayandırılır. Qərb cərrahları tərəfindən çox istifadə edildiyi üçün bu üsul ədəbiyatlarda "qərb üsulu" adı ilə də məhşurdur. Magistral damarlar selektiv olaraq bağlandığ 1 üçün çıxarılan parça tərəfdən qanaxma xeyli azalır, qalan qaraciyər parçasında isə, total işemiya, qapı sistemində venoz durğunluq və dövr edən qanın defisiti baş vermir. Lakin qalan parenxima hissəsindən qanaxma davam edir. Bundan başqa parenximi kəsmədən damarların ayrılması xeyli çətinliklər törədir, bə'zən də onların zədələnməsinə səbəb olur. $\mathrm{Bu}$ vəziyyətlər qaraciyər venalarını sərbəstləşdirərkən daha çox rast gəlir. Digər tərəfdən canlıdan qaraciyər köcürərkən bu üsul tətbiq oluna bilmir.

Mağistral damarlara nəzarət üsullardan biri də total vaskulayar izolyasiya, yə'ni qaraciyərə gələn və çıxan bütün damarların bağlanaraq, qaraciyəri müvəqqəti olaraq tamamilə qansızlaşdırılmasıdır. Bu üsul son illər praktikaya tətbiq edilməyə başlamışdır. Bu üsul rezeksiyanı az qanitirmə ilə həyata keçirməyə imkan versə də, işemiya və portal sistemdə staz törətmək kimi əksik cəhətlərə sahibdir.

Beləliklə, hazırda mə'lum olan "hemostaz-kəsmə" metodları qanaxmanı yetərli dərəcədə dayandırmamaq, parenximada işemiya və nekroz törətmək kimi əksik cəhətlərə malik olduqları üçün sərbəst şəkildə geniş tətbiq tapa bilməmişlər. Lakin, bir çox müsbət cəhətlərinə görə diğər üsullara birlikdə rezeksiya zamanı köməkci vasitə kimi istifadə olunurlar.

\section{PARENXIMANI KOSMO ÜSULLARI}

Qan axınını lokal və total olaraq dayandırdıqdan sonra parenximanın kəsilməsindən ibarət olan "hemostaz-kəsmə" üsullarının qaraciyər rezeksiyalarında başlıca problem olan qanaxmanı yetərincə dayandırmaması alternativ bir yolun - "kəsərkən hemostaz" adlandırdığımız və qanaxmanın 
parenximanın kəsilməsi vaxtı dayandırması prinsipini meydana çıxarmışdır. Hazırda bu prinsip başlıca olaraq parenxima və damarları birlikdə dağlama və qaraciyərdaxili damarları parenximdən ayıraraq bağlayıb kəsmə yolları ilə həyata keçirilir.

\section{Dağlama üsullart}

Elektrikla dağlama (elektrokoaqulyasiya) cərrahiyyədə ən geniş yayılmış koaqulyasiya üsuludur. Müasir elektrokoaqulyatorların geniş güc diapazonu, kəsmə və dağlama rejimlərində işləyə bilməsi onların imkanlarını artırır. Elektriklə dağlama üsulu qaraciyər parenximini və qaraciyərdaxili damar-axacaq strukturlarını sürətlə kəsməyə imkan verir. Lakin bir cox əksik cəhətləri bu usulun qaraciyər rezeksiyalarında istifadəsini məhdudlaşdırır. Elektriklə dağlama qaraciyər parenximasında geniş nekroz törədir. Diametri 0,5-1 mm-dən çox olan damarlar elektriklə dağlama vaxtı koaqulyasiyaya uğramadığından qanaxma baş verir və bunun dayandırılması üçün dağlama gücünü və ya müddətini artırmaq lazım gəlir. $\mathrm{Bu}$ isə, parenximada nekroz sahəsinin daha da genişlədirir, bir çox hallarda isə, qanaxmanı tam dayandıra bilmir. Elektriklə dağlama magistral damarları zədələdiyi üçün onlara yaxın bölgələrdə istifadə edilməsi təhlükəlidir. Ona görə də elektirklə dağlama qaraciyər rezeksiyalarında məhdud şəkildə - Qlisson kapsulunu, qaraciyər bağlarını və az hallarda isə, böyük damarlar olmayan bölgəlrdə kiçik parenxim kəsilmələrində istifadə edilir.

Lazer bıçă̆ cərahiyədə geniş istifadə edilir. Mə'lumdur ki, lazer məcburi şualandırılma nəticəsində gücləndirilmiş monoxromatik və koherent işıq şüalarıdır. Bu xassələr lazerlərin fiziki, kimyəvi, bioloji və s. tə'sir effektlərinin əsasında durur. Şüalandırma dozası (vahid səthə verilən işı̆̆ın enerjisi- güc və zamanın hasili) və şüaların dalğa uzunluğundan asılı olaraq lazerlər toxumalarda müxtəlif növ spesifik və qeyri-spesifik dəyişikliklər törədir. Toxumalarda lazerlərin tə'siri ilə aşağı dozalarda $\left(0,3-5 \mathrm{C} / \mathrm{sm}^{2}\right)$ spesifik biostimulyasiya, orta dozalarda $\left(10-30 \mathrm{C} / \mathrm{sm}^{2}\right)$ bioloji proseslərin ləngiməsi, yüksək dozalarda isə, dağlama $\left(200-400 \mathrm{C} / \mathrm{sm}^{2}\right)$ və buxarlandırma (800 $\mathrm{C} / \mathrm{sm}^{2}$ dozadan artıq) effektləri ortaya çıxır. Lazerlərin cərrahi əməliyyatlarda istifadəsinin əsasında termik tə'sir nəticəsində meydana gələn buxarlandırma, dağlama effektləri və bu effektlərin birmomentli baş verməsi durur. Yüksək 
enerjiyə malik lazer işı̆̆ının tə'sirindən toxumalarda təbiətcə yanıq prosesi olan və morfoloji baxımdan 3 bölgəyə ayrılan "lazer yarası" əmələ gəlir. Mərkəzi yara defekti lazerin yüksək termik təsirindən toxumadaki bərk və maye təbiətli maddələrin birbaşa buxara çevrilməsi nəticəsində əmələ gəlir. Nekroz bölgəsi adlanan ikinci zonanı toxumaların koaqulyasion nekrozu nəticəsində əmələ gəlmiş "koaqulyasion pərdə" və nekrobioza uğramış toxumalar təşkil edir. Nekroz bölgəsinin ətrafında yerləşən üçüncü reaktiv bölgə isə, orqanizmin nekroza qarşı iltihab reaksiyası nəticəsində əmələ gəlir. Lazerin istifadə dozası və toxumanın xüsusiyyətlərindən asılı olaraq bu bölgələrin ölçüləri dəyişir.

Hazırda cərrahiyyədə lazer bıçağı kimi aktiv maddəsi karbon qazı $\left(\mathrm{CO}_{2}\right)$ və yarımkeçiricilər (Er:YAG, Nd:YAG və s.) olan, infraqırmızı diapazonda şüalandıran yüksək enerjili lazerlər daha geniş yayılmışdır. Yumşaq işıqdaşıyıcıların və sapfir ucluğun köməyi ilə lazerlər istənilən dərinlikdəki əməliyatlarda asanlıqla istifadə və idarə oluna bilirlər.

Qaraciyər cərrahiyəsində çıxış gücü 25-80 $\partial$ olan lazerlər $>1000$ $\mathrm{C} / \mathrm{sm}^{2}$ dozada istifadə edilməkdədir. Bu təsir nəticəsində qaraciyərin parenximası kəsilir, damarlar isə, həm dağlanır, həm də kəsilir. İki effekti eyni vaxtda törədə bilmək kimi başlıca üstün cəhətlərə malik olan lazerin qaraciyər cərrahiyəsində yeni era açacağı, "qansız əməliyyat" həyata keçirəcəyi və sür'ətli rezeksiya imkanı yaradacağına böyük ümid yaratmışdı. Ancaq qaraciyərin quruluş xüsusiyyətləri və lazerlərə məxsus bir çox nögsanlarla əlaqədar lazer bıçağı qaraciyər rezeksiyasında əsas problem olan qanaxma problemini tam aradan qaldıra bilmədi.

Birincisi, lazer işığı qaraciyər toxumasında nekroz törədir. Nekrozun ölçüsü müxtəlif müəlliflərə görə 4 mm-dən 2 sm-ə qədər ola bilər. İkincisi, klinik və eksperimental işlər nəicəsində mə’lum olmuşdur ki, diametri $1 \mathrm{sm}$ dən çox olan qaraciyərdaxili damarlar lazerlərlə yetərli dərəcədə dağlanmırlar və ona görə də "qansız rezeksiya" icra etmək mümkün olmur. Yetərli hemostaz üçün uzunmüddətli dağlama lazım gəlir. Bu nekrozun artmasına səbəb olur. Üçüncüsü, kəsilən bölgədə qan dövranı dayandırıldıqda lazer enerjisinin ətrafa yayılmasının azalması ilə əlaqədar, nekroz sahəsi kiçilir, hemostatik effekt və kəsmə sür'əti artır. Ancaq işemiyaya həssaslığı yüksək olan sirrozlu qaraciyərlərdə, canlıdan parça qaraciyər köçürülməsində 
orqanın müvəqqəti də olsa, qansızlaşdırılması mənfi nəticələrə gətirib çıxarır. Dördüncüsü, lazerlə kəsmə vaxtı oksigenin iştirakı ilə gedən yanma prosesi sayəsində toxumaların kömürləşməsi baş verir. Oməliyyat vaxtı görmə sahəsini örtülür, əməliyyatın icrası çətinləşir və magistral damarların zədələnməsi ehtimalı artır.

Arqonlu elektrokoaqulyator iki ünsürü - arqon qazının püskürdülməsi və yüsəktezlikli elektrik cərəyanını birlikdə istifadə etməyə imkan verən cihazdır. Yüksəktezlikli elektrik cərəyanı digər elektrokoaqulyatorlarda olduğu kimi toxumalarda dağlama, kəsmə effektləri törədir. Elektrokoaqulyasiya vaxtı yaraya tökülən qan və toxuma hissələri püskürülən arqon qazı vasitəsi ilə kənarlaşdırılır.Arqon qazı inert qaz olduğundan toxumalarda dəyişiklik törətmir, əksinə dağlama sahəsindən oksigeni qovaraq toxumaların yanması və kömürləşməsinin qarşısını alır. Kəsilən nahiyəyə arqon qazı 2-7 L/dəq. sür'ətlə elektrik cərəyanı ilə birlikdə verilir. Arqon qazının yaranı təmizləməsi və kömürləşmənin qarşısını alması elektrokoaqulyasiya vaxtı kəsilən və dağlanan toxumaların görünməsinə imkan verir, magistral damarların zədələnmə ehtimalı və nekroz sahəsini azaldır. Nekroz bölgəsinin 3-4 mm-ə qədər olduğu göstərilir. Elektrokoaqulyatorlara və lazerlərə görə bu üstünlüklərə malik olan arqonlu elektrokoaqulyatorun bir çox nögsan cəhətləri də var. Yüksək sür'ət və təzyiqlə verilən arqon qazı damarlara keçərək emboliyalar törədə bilər. Xüsusən də böyük damarlara yaxın yerlərdə istifadə edilərkən bu təhlükə daha artır. Püskurmə nəticəsində şiş hüceyrələrinin, viruslu toxumaların ətrafa yayılması da arqonlu elektrokoaqulyatorun mənfi tərəflərindəndir. Yüksəktezlikli elektrik cərəyanı (və ya elektromaqnit dalğaları) arqonlu fəzadan keçərkən arqon atomlarını ionlaşdırır və bu zaman mavi rəngli işıq əmələ gəlir. Ona görə də bə’zən səhv olaraq bu cihazı arqon lazeri və ya arqon şüaları adlandırırlar.Oslində isə, toxumalardakı dağlama ve kəsilmə prosessləri elektrik cərəyanının tə’sirindən baş verir, arqon isə, yalnız püskürtmə effekti yaradır.

Plazma bıçağının cərrahiyədə tətbiqi nüvə reaksiyaları nəticəsində əmələ gələn yüksək plazma enerjisinin toxumalarda dağlama və kəsmə effektləri törətməsinə əsaslanmışdır. Şüalanma təhlükəsi, çətin idarə olunması ilə əlaqədar plazma bıçağı hazırda geniş tətbiq tapmamışdır. 
Qaraciyərin rezeksiya üsulları

\section{Ayırma üsulları.}

Ayırma üsulları adı altında intrahepatik damarlar və axacaqların parenximadan ayıraraq bağlanması prinsipinə əsaslanan metodlar birləşdirilir. Damar- axacaq strukturlarının və parenximatoz hüceyrələrin fiziki xüsusiyyətləri (elastiklik, bərklik, su tutumu) arasındakı fərqin olması onları bir-birindən ayırmağa şərait yaradır. Nisbətən kövrək və incə olan parenximanın mexaniki tə'sirdən əzilməsi, parçalanması və dağılması sayəsində elastikliyi və möhkəmliyi nisbətən yüksək olan damar-axacaq strukturlarının sərbəstləşməsinə imkan yaranır. Hazırda əzmə, ultrasəs və su şırnağı ayırma üsulları istifadə edilməkdədir.

Әzmə üsullarında barmaqların və ya alətlərın köməyi ilə parenxima əzilərək parçalanır, sərbəstləşən damar-axacaq strukturları bağlanıb kəsilir və bu hərəkətlər təkrarlanaraq çıxarılacaq parenximanın tam ayrılmasına qədər davam etdirilir.

Barmaqla əzmə üsulu (digitoklaziya) ayırma metodları içərisində ən qədimidir, 1958-ci ildə T.Y.Lin tərəfindən klinikada istifadə edilmişdir. Qlisson kapsulası kəsildikdən sonra qaraciyər toxuması baş və göstərici barmaqlar arasında əzilir və bu vaxt damar-axacaq elementləri atmalar şəklində ortaya çıxır. Bu üsul hər dəfə ayrılmış damar-axacaq elementlərinin bağlanıb kəsilməsinin təkrarlanması ilə və ya kəsik xətti üzrə bütün damarları sərbəstləşdirdikdən sonra bağlayıb kəsməklə istifadə edilir. Digitoklaziyada adətən diametri 1,5-2 mm-dən az olan damarlar dağılır, böyük damarlar isə, sərbəstləşdirilir. Texniki cəhətdən asan, sürə'tli olması və damarlara barmaqlarla nəzarət edilə bilməsi digitoklaziya üsulunun başlıca üstünlükləridir. Bu üsulla 5-8 dəq. ərzində parenxima ayrılır. Ona görə də qaraciyərin sürətli rezeksiyaları tələb olunan və qan axan böyük damarların tapılması üçün məsləhət görülür. Ancaq, toxumalar barmaqla əzilərkən diametri 1,5-2 mm-dən kiçik damarlar zədələndiyi və parenxima içərisinə qaçdığı üçün qanaxma artır, onun dayandırılması çətinləşir. Xüsusi ilə hipokoaqulyasiya fonunda qanitirmə təhlükəsi çox yüksək olur. Digər üsullarla müqayisədə barmaqla əzmə vaxtı daha çox toxuma zədələndiyi üçün (2-3 sm) nekroz sahəsi böyük olur.

Prinsipcə barmaqla əzmə üsuluna yaxın olan alətlə əzmə metodunda parenxima küt alətlərin köməyi ilə əzilərək içərisindəki damarlar 
sərbəstləşdirilir. Bu məqsədlə bıçaq sapı, arterial sıxıcılar, toxuma ayırıcıları (dissektor) və xüsusi olaraq bunun üçün hazırlanmış alətlər istifadə edilir. Damar-axacaq elementlərinin daha aydın görünməsi üçün kəsik sahəsindəki toxuma parçaları və qan vakuum sorucusu ilə təmizlənir. Barmaqla əzmə metodundan fərqli olaraq alətə əzmə üsulunda nekroz sahəsi kiçik olur $(1,5$ $\mathrm{sm})$ və kiçik damarlar (1 $\mathrm{mm}-ə$ yaxın) ayrıldığından qanaxma az olur. Ancaq bu üsul qaraciyərin rezeksiya müddətini xeyli artırır.

Ozərək ayırma üsullarının biri də tikiş sapı ila azmə metodudur. Parenxima parçasından alətlərin köməyi ilə keçirilmiş tikiş sapı bağlanarkən parenxima kəsilir, damar və axacaqlar bağlanır. Damarların görünmədən, nəzarətsiz, kor-koranə bağlanması və düyün içərisinə parenximanın alınması ilə əlaqədar əməliyyatdan sonra nekroz, septik ağırlaşmalar və qanaxmalar baş verir.

\section{Sorucu bıçaqla rezeksiya}

Sorucu bıçaq adlanan alətin işləmə prinsipinin əsasında qaraciyər parenximasının kiçik boru ilə yüksək təzyiqdə sorulması və bu vaxt parenximadaxili damar və axacaqların sərbəstləşməsi durur. Parenxima sorulduqdan sonra sərbəstləşən damar və axarlar bağlanıb kəsilir və ya koaqulyasiya olunur. $\mathrm{Bu}$ metodun bir çox çatışmayan cəhətləri vardır. Birincisi, sirrozlu qaraciyərdə aşırı fibroz olduğu üçün sorucu bıçaqla qaraciyər parenximasını ayırmaq çətinlik törədir. İkincisi, bu metodla xəstə qaraciyərdə rezeksiya zamanı elastikliyini itirmiş damarlar asanlıqla zədələnir və qanaxmaya səbəb olur.

Ayırma üsullarından biri də su şırnăğ ilə rezeksiya metodudur. Yüksək təzyiq altında $\left(12-50 \mathrm{Kg} / \mathrm{sm}^{2}\right)$ kiçik diametrli $(0,1-0,5 \mathrm{~mm})$ borudan keçən su şırnağı qaraciyər parenximasına yönəldilir. Bu təzyiqin tə’siri nəticəsində parenxima hüceyrələri damarlardan qopub ayrilır. Diametri 0,2 mm-dən kiçik damarlar zədələnir, böyük damarlar isə, zədələnmədən sərbəstləşir. Çox kiçik damarlar eljtrokoaqulyatorla dağlanaraq, nisbətən iri damarlar isə, bağlanaraq kəsilir. Normal qaraciyərdə $12-20 \mathrm{Kg} / \mathrm{sm}^{2}$ təzyiq yetərli olduğu halda, sirrozlu qaraciyərdə fibrotik prosesin dərəcəsindən asılı olaraq şırnağın təzyiqinı artırmaq lazım gəlir. Qaraciyər toxumasında çox az nekroz törətməsi (1-2mm), ucuz olması, çox kiçik damarları zədələməməsi bu üsulun səciyyəvi üstünlükləridir. Ancaq bu üsulun da bir çox əksik 
cəhətləri də var. Su şırnağının qaraciyərə toxunarkən köpüklənməsi, qan və toxuma parçaları ilə qarışması sayəsində kəsik sahəsi örtülür, görmə çətinləşir. Kiçik damarlar $(<0,2 \mathrm{~mm})$ dağlanmadığı üçün kapilyar tipli qanaxma baş verir və koaqulyasya pozulmalarında bu qanaxmalar təhlükəli olur. Şırnaq şiş hüceyrələrinin, infeksiyalı toxumaların ətrafa yayılmasına da səbəb olur. Oməliyat müddətinin nisbətən artıq olması da şırnaqla rezeksiya üsulunun əksik cəhətlərindəndir.

\section{Ultrasoslo ayırma}

Ultrasəs dalğalarının cərrahi bıçaq kimi istifadəsinə 1970-ci illərin sonundan başlanmışdır. Qaraciyər rezeksiyasına olan təlabatın artması və lazer, eletrokoaqulyator kimi ümidverici üsulların rezeksiya problemlərini yetərli dərəcədə həll edə bilməməsi 1990-c1 illərdə ultarasəslə ayırma metodunun inkişafına təkan verdi.

Ultrasəs dalğalarının cərrahiyədə tətbiqinin əsasında toxumalarda törətdiyi kavitasiya hadisəsinin durduğu hesab edilir. Kavitasiya, yüksək enerjinin tə'siri ilə mühitdə olan molekulların sür'ətli hərəkət əldə edərək buxara çevrilməsi, buxar qovucuqlarının əmələ gəlməsi və qovucuqların partlaması hadisəsidir. Qovucuqların partlaması hüceyrəvi və qeyrihüceyrəvi strukturların parçalanması, dağılması və destruksiyasını törədərək toxumada defektin, yaranın əmələ gəlməsinə səbəb olur. Toxumanın fizikikimyəvi xususiyyətləri və verilən dalğanın enerjisindən asılı olaraq ultrasəsin toxumada törətdiyi effekt müxtəlifdir. Su ilə zəngin və zərif olan parenxima hüceyrələri və kapilyarlar nisbətən azenerjili dalğaların təsirindən və daha tez destruksiyaya uğrayırlar. Birləşdirici toxuma lifləri ilə zəngin olan bağlar, fassiya, böyük ölçlü damar və axacaq elementlərinin zədələnməsi üçün daha böyük enerji tələb olunur. Parenxima və damar-axacaq elementlərinin fizikikimyəvi xüsusiyətləri arasındakı fərqə və buna uyğun dalğa enerjisi ilə strukturların bir-birindən ayrılması ultrasəsin qaraciyər rezeksiyasında tətbiqinin əsasında durur. Müəyyən olunmuşdur ki, saniyədə verilən 1-3 $\mathrm{KC} / \mathrm{sm}^{2}$ (1-3 KӘ/ $/ \mathrm{sm}^{2}$ gücündə) ultrasəs enerjisi parenximada destruksiya və $1 \mathrm{~mm}$-dən kiçik damarlarda dağlanma törətdiyi halda, Qlisson kapsulunu, peritonu, qaraciyərdəki $1 \mathrm{~mm}$-dən böyük damarları zədələmir. Nəticədə bu ölçüdəki damar və axacaqlar parenximadan ayrılaraq sərbəstləşdirilir və onlara nəzarət üçün şərait yaranır. Müqayisə, üçün qeyd etmək olar ki, 
müayinə üçün istifadə olunan ultrasəs cihazları $3 \mathrm{Mhz}$ tezlikli və $10 \mathrm{~m} / \mathrm{sm}^{2}$ gücündə ultrasəs dalğalandırırlar.

Hazırda qaraciyər rezeksiyasında CUSA (Cavitron Ultrasonic Surgical Aspirator) adlanan ultrasəs ayırıcisı istifadə edilir. Bu cihaz prinsipal olaraq 3 prosesi eyni vaxtda həyata keçirməyə imkan verir: ultarasəs kavitasiyas1; su ilə yuma; sorma. Cihazdan $23 \mathrm{Khz}$ tezlikdə, və $100 \mathrm{mkm}$ dalğa uzunluqlu ultrasəs çıxır. Bu dalğalar diametri $2 \mathrm{~mm}$ olan vibratordan çıxaraq $2,5 \mathrm{~K} / \mathrm{sm}^{2}$ güc sixlığ 1 yaradır və toxumaya $2,5 \mathrm{~K} / \mathrm{sm}^{2}$ dozada enerji verilməsini tə'min edir.

Ultrasəslə birlikdə vurulan su ultrasəs dalğalarının toxumaya yayılması üçün mühit yaradır, şırnaq effekti törədərək hüceyrələrin damaraxacaq elementlərindən asanlıqla ayrılmasına imkan verir. Sorucu isə, yaradakı parçaları, su və qanı təmizləyərək rezeksiya sahəsinin aydın görünməsi üçün şərait yaradır.

Ultrasəs kavitasiyası, su şırnağı və sorma proseslərinin eyni vaxtda həyata keçirilməsi nəticəsində kiçik damarlar $(<1 \mathrm{~mm})$ dağlanır, parenximada defekt yaranır, parenximadan ayrılaraq sərbəstləşən və defektdə aydın görünən damar-axacaq elementlərinin (diametri $>1 \mathrm{~mm}$ ) bağlanıb kəsilməsi mümkün olur. $\mathrm{Bu}$ elementlərin bağlanması üçün avtomatik klemplərin istifadə edilməsi kəsmə prosesini sür'ətləndirməyə imkan verir. Beləliklə qaraciyərin sür'ətli və az qanaxmalı rezeksiyası həyata keçirilir.

Ultrasəs bıçağının 70-ci illərdən, CUSA tipli cihzın isə, 90-c1 illərdən başlayaraq ümumi cərrahiyyədə, ginekologiyada, neyrocərrahiyyədə istifadə edilməsinə baxmayaraq onun üstün və əksik cəhətləri ilə əlaqədar müxtəlif fikirlər var. Rezeksiya vaxtı baş verən qanaxmanın miqdarına görə aparılan tədqiqatların əksəriyyətində ultrasəs üsulunun digitoklaziyaya nisbətən qanaxmanı xeyli azaltmasını göstərilir. Digitoklaziya vaxtı qaraciyərin vahid səthinə düşən qanaxma miqdarı $32,5 \mathrm{ml} / \mathrm{sm}^{2}$ olduğu halda, ultrasəslə rezeksiyalarda bu miqdar $24,3 \mathrm{ml} / \mathrm{sm}^{2}$ təşkil etmişdir. Әzmə üsullarında rezeksiyanın həcmindən asılı olaraq qanaxma orta hesabla 1,5-3 1 təşkil etdiya halda, uyğun həcmli rezeksiyalarda ultrasəs tədbiq edildikdə qanaxmanın miqdarı 0,6-1,5 1-ə qədər azalmışdır, qanköçürməyə təlabat isə, azalmışdır. Ancaq ədəbiyatda ultrasəs üsulunun əzmə üsulu ilə müqayisədə qanaxma miqdarını azltmadığını göstərən faktlar da vardır. 
Qaraciyərin rezeksiya üsulları

Ultrasəs üsulunun elektokoaqulyasiya və lazerlərlə müqayisədə qanaxma miqdarını azaltması bir neçə tədqiqatda göstərilmişdir. Oksinə, lazer və ulatrasəs üsulları arasında qanaxma miqdarına görə ciddi fərq olmadığını təsdiq edən işlər də mövcuddur.

Oməliyyata sərf edilən zamana görə ulatrasəs üsulu ilə digər rezeksiya üsullarının müqayisəsinə həsr edilmiş işlərdə müxtəlif nəticələr ortaya çıxmışdır. Bə'zi araşdırmalarda ultrasəsin digitoklaziya və lazerə nisbətən əməliyyat müddətini azaltması qeyd edilir. Bir çox tədqiqatlarda isə, əzmə, ultrasəs və lazer üsullarının əməliyyat müddətinə görə bir-birindən fərqlənməməsi göstərilmişdir. Parenximanı kəsmə sür’ətinə görə aparılan tədqiqatlarda ulatrasəslə $(0,50 \mathrm{dəq} / \mathrm{sm} 2)$ əzmə metodu $(0,57 \mathrm{dəq} / \mathrm{sm} 2)$ arasında ciddi fərq olmaması nəticəsi meydana çıxmışdır. Odəbiyyatda nəticə müxtəlifliyinin başlıca səbəblərindən biri əməliyyata sərf edilən vaxtın hesablanmaları arasındakı fərqin olmasıdır. Çünki, bir çox müəlliflər tam əməliyyat vaxtını, bə'ziləri qaraciyərin kəsilmə və tam hemostaz müddətini, digərləri isə, sadəcə parenximanın kəsilməsinə sərf edilən vaxtı (damar-axacaq elementlərinin ayrılmasını) nəzərə almışlar. Zənnimizcə bu üsulların müqayisəsi qaraciyərin kəsilməsi və tam hemostaza sərf edilən zamana görə və qaraciyərin struktural dəyişikliklərini nəzərə alaraq aparılsa idi, daha doğru nəticələr ortaya çıxardı.

Beloliklo, hazırda qaraciyor rezeksiyası üçün mövcud olan üsulların heç biri “ideal rezeksiya üsulu” toloblorino, yo'ni minimal qanaxma vo ya qanaxması, sür'ətli kəsmo, qaraciyordo nekroz törotməmo vo sirrotik qaraciyorlordo do effektli ola bilmo kimi tolobloro yetorli doracədo cavab vermirlor. Ona göro do qaraciyər rezeksiyası üçün yeni effektiv üsulların axtarışı corrahi hepatologiyanın vacib mosolosi olaraq qalmaqdadir. 
Cadval 4.1. Qaraciyər rezeksiyalarında istifadəedilən üsulların qanaxmanı dayandırma imkanları üstünlüklari, nöqsanları va tatbiqina göstวrişlar

\begin{tabular}{|c|c|c|c|c|c|}
\hline $\begin{array}{l}\text { ÜSULLAR } \\
\text { Hemostatik } \\
\text { tikişlor }\end{array}$ & $\begin{array}{l}\text { Hemostaz } \\
\text { mexanizmi } \\
\text { Parenxima və } \\
\text { damarları } \\
\text { birlikdə s1xma }\end{array}$ & $\begin{array}{l}\text { Hemostaz } \\
\text { imkanları } \\
\text { Kapilyarlar, } \\
\text { çapı }<1 \mathrm{~mm} \\
\text { venalar }\end{array}$ & $\begin{array}{l}\text { Üstünlükləri } \\
\text { Olavə vəsait tələb etməməsi } \\
\text { Asan olması } \\
\text { Dərinə qaçmış damarlarlardan } \\
\text { qanaxmanı dayandırması }\end{array}$ & $\begin{array}{l}\text { Nöqsanları } \\
\text { Nekroz törətməsi (1-2 sm) } \\
\text { Yetərsiz intraopersyon } \\
\text { hemostaz (arteriyal) } \\
\text { Oməliyatdan sonra } \\
\text { qanaxmalar (nekrozla } \\
\text { əlaqədar) }\end{array}$ & $\begin{array}{l}\text { Totbiqina } \\
\text { göstorişlar } \\
\text { İntraoperasyon } \\
\text { biopsiyalar }\end{array}$ \\
\hline $\begin{array}{l}\text { Hemostatik } \\
\text { slxıcı alot }\end{array}$ & $\begin{array}{l}\text { Parenxima və } \\
\text { damarları } \\
\text { birlikdə sıxma }\end{array}$ & $\begin{array}{l}\text { Kapilyarlar, } \\
\text { çapı }<1 \mathrm{~mm} \\
\text { venalar }\end{array}$ & Asan və tez olmas 1 & $\begin{array}{l}\text { Nekroz törətməsi }(1-2 \mathrm{sm}) \\
\text { Müvəqqəti olması və daimi } \\
\text { hemostaz üçün digər } \\
\text { üsulların lazım gəlməsi } \\
\text { Qaraciyərin arxa və } \\
\text { mərkəzi seqmentlərinə } \\
\text { qoyula bilməməsi }\end{array}$ & $\begin{array}{l}\text { İntraoperasyon } \\
\text { biopsiyalar }\end{array}$ \\
\hline $\begin{array}{l}\text { Magistral } \\
\text { damarlara } \\
\text { selektiv } \\
\text { nozarot }\end{array}$ & $\begin{array}{l}\text { Çıxarılan } \\
\text { parçanın qan } \\
\text { dövranının } \\
\text { tam və ya } \\
\text { hissəvi olaraq } \\
\text { dayandırılması }\end{array}$ & $\begin{array}{l}\text { Kollaterallar } \\
\text { dan və qalan } \\
\text { hissəninkind } \\
\text { ən başqa } \\
\text { bitün } \\
\text { damarlar }\end{array}$ & $\begin{array}{l}\text { Qanaxma təhlükəsinin } \\
\text { azalmas1 } \\
\text { Digər üsullarla birlikdə istifadə } \\
\text { oluna bilməsi }\end{array}$ & $\begin{array}{l}\text { Qalan paydan qanaxmanın } \\
\text { olması və bunu } \\
\text { dayandırmaq üçün digər } \\
\text { üsulların lazım gəlməsi } \\
\text { Damarları ayırarkən } \\
\text { çətinliklər və zədələmə } \\
\text { təhlükəsi } \\
\text { Canlıdan qaraciyər } \\
\text { köçürülməsində istifadə } \\
\text { edilə bilməməsi }\end{array}$ & $\begin{array}{l}\text { Digər üsullarla } \\
\text { birlikdə qeyri- } \\
\text { transplantasya } \\
\text { lobektomiyalarda }\end{array}$ \\
\hline $\begin{array}{l}\text { Pringler } \\
\text { üsulu }\end{array}$ & $\begin{array}{l}\text { Qap1 } \\
\text { damarların1 } \\
\text { müvəqqəti } \\
\text { sixma }\end{array}$ & $\begin{array}{l}\text { Kollaterallar } \\
\text { dan və } \\
\text { qaraciyər } \\
\text { venalarından }\end{array}$ & $\begin{array}{l}\text { Qanaxma təhlükəsinin } \\
\text { azalmas1 } \\
\text { Digər üsullarla birlikdə istifadə } \\
\text { oluna bilməsi }\end{array}$ & $\begin{array}{l}\text { Müvəqqəti olması və daimi } \\
\text { hemostaz üçün digər } \\
\text { üsulların lazım gəlməsi }\end{array}$ & $\begin{array}{l}\text { Qaraciyər } \\
\text { travmalarında } \\
\text { qanaxma } \\
\text { mənbəyinin }\end{array}$ \\
\hline
\end{tabular}


Cwdvwl 4.1. Qaraciywr rezeksiyalarında istifadwedilwn üsulların qanaxmanı dayandırma imkanları üstünlüklwri, nöqsanları vw twtbiqinw göstwrișlwr (davamı)

\begin{tabular}{|c|c|c|c|c|c|}
\hline$\ddot{U S U L L A R}$ & $\begin{array}{l}\text { Hemostaz } \\
\text { mexanizmi }\end{array}$ & $\begin{array}{l}\text { Hemostaz } \\
\text { imkanlart }\end{array}$ & Üstünlüklori & Nöqsanlart & $\begin{array}{l}\text { Totbiqino } \\
\text { göstorişlor }\end{array}$ \\
\hline & & $\begin{array}{l}\text { başqa } \\
\text { qaraciyərə } \\
\text { gələn bütün } \\
\text { damarlar }\end{array}$ & $\begin{array}{l}\text { Tə'cli vəziyətlərdə istifadə } \\
\text { oluna bilmesi } \\
\text { Asan və tez olması } \\
\text { Qanaxma mənbəyinin tə’yin } \\
\text { edilməsi }\end{array}$ & $\begin{array}{l}\text { Qaraciyər venalarından } \\
\text { qanaxmanın davam etməsi } \\
\text { Qaraciyərdə işemiya,portal } \\
\text { sistemde staz yaratması } \\
\text { Sirrozlarda və canlıdan } \\
\text { qaraciyər köçürülməsində } \\
\text { istifadə imkanının az } \\
\text { olması }\end{array}$ & $\begin{array}{l}\text { tə’yin etmək } \\
\text { üçün } \\
\text { İstənilən üsulla } \\
\text { birlikdə, } \\
\text { qanaxmanı } \\
\text { müvəqqəti } \\
\text { dayandırmaq və } \\
\text { ya azltmaq üçün }\end{array}$ \\
\hline $\begin{array}{l}\text { Elektriklo } \\
\text { dağlama }\end{array}$ & $\begin{array}{l}\text { Damarların } \\
\text { dağlanması }\end{array}$ & $\begin{array}{l}<1 \mathrm{~mm} \\
\text { damarlar }\end{array}$ & $\begin{array}{l}\text { Birmomontli hemostaz və } \\
\text { kəsmə } \\
\text { Sür’ətli kəsmə } \\
\text { Laxtalanma pozulmalarında } \\
\text { istifadə edilməsi }\end{array}$ & $\begin{array}{l}\text { Nekroz törətməsi (1-1,5 } \\
\text { sm) } \\
1 \text { mm-dən böyük } \\
\text { damarlardan qanaxma } \\
\text { Kömürləşmənin görmə } \\
\text { sahəsini örtməsi } \\
\text { Magistral damarları } \\
\text { zədələyə bilməsi }\end{array}$ & $\begin{array}{l}\text { Kiçik damarlar } \\
\text { olan bölgələrin } \\
\text { kəsilməsi } \\
\text { (Qlisson kapsulu, } \\
\text { periferik } \\
\text { parenxima) } \\
\text { Hipokoaqulyasya }\end{array}$ \\
\hline Lazer bıçă̆ & $\begin{array}{l}\text { Damarların } \\
\text { dağlanması }\end{array}$ & $\begin{array}{l}<2 \mathrm{~mm} \\
\text { damarlar }\end{array}$ & $\begin{array}{l}\text { Birmomontli hemostaz və } \\
\text { kəsmə } \\
\text { Sür’ətli kəsmə } \\
\text { Laxtalanma pozulmalarında } \\
\text { istifadə edilməsi } \\
\text { Fibroz toxumaları tez kəsməsi }\end{array}$ & $\begin{array}{l}\text { Nekroz törətməsi (1-1,5 } \\
\text { sm) } \\
2 \text { mm-dən böyük } \\
\text { damarlardan qanaxma } \\
\text { Kömürləşmənin görmə } \\
\text { sahəsini örtməsi } \\
\text { Magistral damarları } \\
\text { zədələyə bilməsi } \\
\text { Effektliliyini artırmaq üçün } \\
\text { işemiya lazım gəlməsi }\end{array}$ & $\begin{array}{l}\text { Hipokoaqulyasya } \\
\text { İşemiya } \\
\text { törətməyə imkan } \\
\text { olduqda bütün } \\
\text { rezeksiyalarda }\end{array}$ \\
\hline $\begin{array}{l}\text { Arqonlu } \\
\text { elektro- } \\
\text { koaqulyator }\end{array}$ & $\begin{array}{l}\text { Damarların } \\
\text { dağlanması, } \\
\text { arqon qazı } \\
\text { püskürdülməsi }\end{array}$ & $\begin{array}{l}<2 \mathrm{~mm} \\
\text { damarlar }\end{array}$ & $\begin{array}{l}\text { Birmomontli hemostaz və } \\
\text { kəsmə } \\
\text { Sür'ətli kəsmə }\end{array}$ & $\begin{array}{l}\text { Nekroz törətməsi (1-1,5 } \\
\text { sm) } \\
2 \text { mm-dən böyük } \\
\text { damarlardan qanaxma }\end{array}$ & $\begin{array}{l}\text { Hipokoaqulyasya } \\
\text { Magistral } \\
\text { damarlardan və }\end{array}$ \\
\hline
\end{tabular}


Cwdvwl 4.1. Qaraciywr rezeksiyalarında istifadwedilwn üsulların qanaxmanı dayandırma imkanları üstünlüklwri, nöqsanları vw twtbiqinw göstwrislwr (davamı)

\begin{tabular}{|c|c|c|c|c|c|}
\hline$\ddot{U} S U L L A R$ & $\begin{array}{l}\text { Hemostaz } \\
\text { mexanizmi }\end{array}$ & $\begin{array}{l}\text { Hemostaz } \\
\text { imkanlart }\end{array}$ & 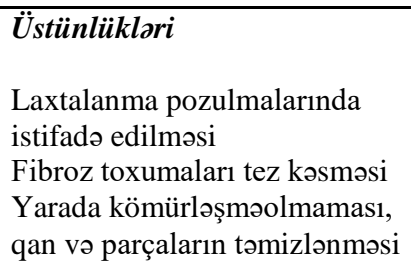 & $\begin{array}{l}\text { Nöqsanlart } \\
\text { Qaz emboliyası } \\
\text { Magistral damarları } \\
\text { zədələyə bilməsi } \\
\text { Şiş və viruslu hüceyrələri } \\
\text { ətrafa yayma }\end{array}$ & $\begin{array}{l}\text { Totbiqinə } \\
\text { göstorişlər } \\
\text { şişlərdən kənar } \\
\text { rezeksiyalarda } \\
\text { Sirrozlu } \\
\text { qaraciyərdə }\end{array}$ \\
\hline $\begin{array}{l}\text { Barmaqla } \\
\text { ozmo }\end{array}$ & $\begin{array}{l}\text { Damarların } \\
\text { parenximdən } \\
\text { ayrılaraq } \\
\text { bağlanması }\end{array}$ & $\begin{array}{l}>2 \mathrm{~mm} \\
\text { damarlar } \\
\text { sərbəstləşir }\end{array}$ & $\begin{array}{l}\text { Sür’ətli kəsmə } \\
\text { Asan olmas1 } \\
\text { Damarlara barmaqla nəzarət }\end{array}$ & $\begin{array}{l}\text { Böyük nekroz bölgəsi (2-3 } \\
\text { sm) } \\
2 \text { mm-dən kiçik } \\
\text { damarlardan qanaxma } \\
\text { Hipokoaqulyasiyalarda } \\
\text { istifadə edilə bilməməsi }\end{array}$ & $\begin{array}{l}\text { Travmalarda } \\
\text { Qanayan böyük } \\
\text { damaralrın } \\
\text { tapılmasında }\end{array}$ \\
\hline Alatlo azmo & $\begin{array}{l}\text { Damarların } \\
\text { parenximdən } \\
\text { ayrılaraq } \\
\text { bağlanması }\end{array}$ & $\begin{array}{l}>1 \mathrm{~mm} \\
\text { damarlar } \\
\text { sərbəstləşir }\end{array}$ & $\begin{array}{l}\text { Nekrozun az olması }(<1,5 \mathrm{sm}) \\
\text { Qanaxmanın az olması }\end{array}$ & Uzun vaxt tələbi & $\begin{array}{l}\text { İstənilən tipli } \\
\text { rezeksiyalarda }\end{array}$ \\
\hline Tikişlo azmo & $\begin{array}{l}\text { Parenximanın } \\
\text { hissəvi } \\
\text { kəsilərək } \\
\text { damarlarla } \\
\text { birgə } \\
\text { bağlanması } \\
\end{array}$ & $\begin{array}{l}>1 \mathrm{~mm} \\
\text { damarlar } \\
\text { bağlanır }\end{array}$ & $\begin{array}{l}\text { Nisbətən sür'ətli kəsmə } \\
\text { Asan olması }\end{array}$ & $\begin{array}{l}\text { Böyük nekroz bölgəsi (2 } \\
\text { sm) } \\
\text { Kor kəsmə } \\
\text { Oməliyyatdan sonra } \\
\text { qanaxmalar. }\end{array}$ & Biopsiyalarda \\
\hline $\begin{array}{l}\text { Su şırnă̆ } \\
\text { ilo ayırma }\end{array}$ & $\begin{array}{l}\text { Parenximanı } \\
\text { damarlardan } \\
\text { suyun təzyiqi } \\
\text { ilə ayrılması }\end{array}$ & $\begin{array}{l}>0,2 \mathrm{~mm} \\
\text { sərbəstləşir }\end{array}$ & $\begin{array}{l}\text { Az nekroz törətməsi }(1-2 \mathrm{~mm}) \\
\text { Kiçik damarları }(>0,2 \mathrm{~mm}) \\
\text { parenximadan ayırma } \\
\text { Ucuz olması }\end{array}$ & $\begin{array}{l}\text { Otrafa su siçraması } \\
\text { Şiş və viruslu hüceyrələri } \\
\text { ətrafa yayma } \\
\text { Köpüklənmə nəticəsində } \\
\text { görmənin pisləşməsi }\end{array}$ & $\begin{array}{l}\text { İstənilən həcmli } \\
\text { rezeksiyalar }\end{array}$ \\
\hline $\begin{array}{l}\text { Ultrasəs } \\
\text { bıçağıl } \\
(\text { CUSA) }\end{array}$ & $\begin{array}{l}\text { Parenximanı } \\
\text { damarlardan } \\
\text { ultrasəs } \\
\text { kavitasiyas } 1\end{array}$ & $\begin{array}{l}>1 \mathrm{~mm} \\
\text { damar və } \\
\text { axacaqlar } \\
\text { sərbəstləşir }\end{array}$ & $\begin{array}{l}\text { Ayırma, yuma və sorma } \\
\text { prosesləri birmomenttli olur } \\
\text { Kiçik damarlar dağlanır }(<1 \\
\text { mm) } \\
\text { Nekroz azdır }(1-2 \mathrm{~mm})\end{array}$ & $\begin{array}{l}\text { Fibrotik qaraciyərlərdə } \\
\text { əməliyyat müddəti artır } \\
\text { Hipokoaqulyasiiyalı } \\
\text { xəstələrdə kapilyar } \\
\text { qanaxma başverə bilir. }\end{array}$ & $\begin{array}{l}\text { İstənilən həcmli } \\
\text { rezeksiyalar }\end{array}$ \\
\hline
\end{tabular}


Cwdvwl 4.1. Qaraciywr rezeksiyalarında istifadwedilwn üsulların qanaxmanı dayandırma imkanları üstünlüklwri, nöqsanları vw twtbiqinw göstwrișlwr (davamı)

\begin{tabular}{|llllll|}
\hline$\ddot{U S U L L A R}$ & $\begin{array}{l}\text { Hemostaz } \\
\text { mexanizmi } \\
\text { sayəsində } \\
\text { ayırma }\end{array}$ & $\begin{array}{l}\text { Hemostaz } \\
\text { imkanlart }\end{array}$ & Üstünlükləri & Nöqsanlart & $\begin{array}{l}\text { Totbiqino } \\
\text { göstorişlor }\end{array}$ \\
\hline
\end{tabular}




\section{BÖLÜM.}

\section{QARACIYOR REZEKSIYYASININ TEXNIKKASI}

\section{II morhold: ЭMӘLIYYATDAXILII DİAQNOSTIKA}

Oməmliyyatdaxili diaqnostika xəstəliyin, rezeksiyaya göstəriş və əks göstərişin müəyyən edilməsində son və həlledici mərhələdir. $\mathrm{Bu}$ mərhələdəki və əməliyyatönü müayinələrə əsaslanaraq rezeksiya olunma və ya rezeksiyadan imtina qərarı verilir. Oməliyyatdaxili diaqnostikada iki əsas məsələ həll edilir. Birincisi, xəstəlik rezeksiya tələb edirmi və rezeksiya oluna bilərmi, yə’ni xəstəlik rezektabeldirmi? İkincisi, tələb olunan rezeksiya həcmi nə qədərdir və qaraciyər buna davam gətirə bilərmi, yə'ni qaraciyar rezektabeldirmi ?

Bu məsələlərin həlli üçün əməliyyatönü müayinələrin nəticələri nəzərə alınmaqla bərabər qaraciyər və ətraf orqanlar əməliyyat vaxtı müayinədən kəçirilir. Baxma, palpasiya, lazım gəldikdə tə'cili patohistoloji, punksiya, ultrasas müayinalari yerina yetirilir. $\mathrm{Bu}$ müayinələr xəstəlik və qaraciyər haqqında mə'lumatlar verir.

Normal qaraciyər tünd qəhvəyi rəngdə, kənarları kəskin, səthi hamar olub ön kənarı qaborğa qövsü səviyyəsindədir, palpasyonda konsistensiyası yumşaqdır və içində kütlə əllənmir. Kəskin və ya kəskinləşmiş hepatitlərdə qaraciyərin ölçüsü böyümüş olub qabırğa qövsündən kənara çıxır, kənarları kütləşir və şişkindir, rəngi nisbətən avazımışdır. Konsistensiyasını sərtləşməsi xronik hepatit, sirroz və ya fibrozla əlaqədar birləşdirici toxumanın inkişaf etdiyini göstərir. Yayğın düyünlərin olması, avazımış rəng, sərt konsistensiya və portal hipertenziya (assit, qaraciyər qapısında və ətrafında genişlənmiş venoz damarlar) sirrozun başlica əlamətləridir və adətən sol paayın hipertrofiyası müşahidə edilir.

Oməliyyatdaxili ultrsəs müayinəsinin iki ühüm əhəmiyyəti var. Birincisi, qaraciyərdəki patoloji kütlənin ölçülərini, damar və axacaqlara münasibətini tə'yin etmək, palpasiya olunmaayan qaraciyərdaxili kütlələrin yerini, ölçüsünü müəyyən etmək üçün. İkincisi, qaraciyər pay və seqmentlərin sərhəddini, xüsusuən də qaraciyər venalarının yerini müəyyən etmək üçün.

Punksiya kütlənin kistik və ya toxumalı olduğunu, patohistoloji müayinə isə kütlənin təbiətini və ya qaraciyər parenximasının vəziyyətini müəyyən etmək üçün istifadə edilir.

Birinci masəlnin- xasaliyin rezeksiya talab etmasi va rezektabelliyinin həlli üçün patoloji kütlənin təbiəti, yeri, ölçüsü, və yayılma dərəcəsi müəyyən edilir. Ortası çökük, kənarları qaraciyər səthindən yuxarı qalxmış, "nəlbəki “ tipli sərt kütlə adətən metastatik adenokarsinomalarda olur. Sərt, səthi düzənsiz səthi olan kütlələr 
hepatosellular karsinomalarda, yumşaq, elastik, səthi hamar, qırmızıya çalan rəngli kütlələr isə hemangiomalarda olur. Kistlər adətən düzgün səthi, ağımtıl rəngli divarı olan elastik və ya sərt-elastik kütlələrdir. Kütlənin kist və ya toxuma tipli olduğunu müəyyən etmək üçün USM və ya punksiya edilə bilər.

Xəstəliyin rezektabelliyi iki cəhəti ilə müəyyən edilir: tabiəti va yayllma dorəcəsi. Bəd xassəli şişlər mütləq və sağlam toxuma səviyyəsində rezeksiya tələb edir. Xoşxassəli şişlər kapsulları və ya hüdudları səviyyəsində rezeksiya oluna bilərlər. Kistlərdə isə rezeksiya adətən periferik (kist divarının 1/3-dən azı qaraciyərlə bitişik olduqda) tipli olduqda uyğundur.

Xəstəliyin qaraciyər daxilinə və xaricinə yayılma dərəcəsi rezektabelliyi müəyyən edən ikinci əsas amildir. Qaraciyərdən kənar orqanlara, xüsusən magistral damarlara (qaraciyər venası, aşağı boş vena, qap1 damarları), limfa düyünlərinə sirayət edən və/və ya hər iki payda da olan bəd xassəli şişlər rezeksiya olunmaz hesab edilir. Qaraciyərin bir payında yerləşən, magistral damarlara sirayət etməmiş şişlər rezeksiya edilə bilərlər. Ona görə də əməliyyatdaxili müayinə vaxtı hər iki pay diqqətlə müayinə edilməlidir, magistral damarların və limfa düyünlərinin vəziyyətinə baxılmalıdır. Assit adətən rezeksiyaya əks göstəriş hesab edilir. Çünki, assit ya dekompensasya mərhələsindəki sirrozu, ya magistral damarlara sirayəti, ya da limfadik damarların şişlə blokadasını göstərir. Palpasiya ilə səthdə yerləşən, USM və BT isə dərində yerləşən kütlələrin aşkar edilməsi üçün daha həssasdır.

İkinci məsələ- qaraciyərin rezektabelliyinin müəyyən olunmasında əsas amillər rezeksiya həcmi və qaraciyərin funksional ehtiyatlarıdır. Oməliyyat vaxtı qaraciyər həcmini tə’yin etmək üçün sağ payı $65 \%$, sol pay1 isə $35 \%$ qəbul etmək olar. Normal qaraciyərin $75 \%$ qədəri rezeksiya edilə bilər. Sirroz və xronik hepatitdə qaraciyərin davam gətirilə biləcək rezeksiya həcmi bu xəstəliklərin ağırlıq dərəcəsindən asılıdır. $\mathrm{Bu}$ xəstələrdə rezeksiya həcmini tə’yin etmək üçün əməliyyatönü qaraciyər göstəriciləri və əməliyyatdaxili müayinə nəticələri birlikdə qiymətləndirilir. Kəskin hepatitdə hər növ rezeksiya əks göstərişdir. Oməliyyat vaxtı bariz assiti olan, Child $\mathrm{C}$ grubuna dahil olan hastalarda rezeksiya edilməməlidirlər. Child B qrubunda 30\% qədər rezeksiya, Child A qrubunda isə $70 \%$ qədər rezeksiya edilə bilər. Bu üsullar təxmini olduqları üçün dəqiq nəticələr vermirlər. Ona gərə də daha obyektiv üsul olan əməliyyatdaxili indosianin yaşıl sınağı (ODİSYS) aparılması məsləhət görülür.

Әməliyyatdaxili indosianin yaşı1 indeksi böyük və orta həcmli qaraciyər rezeksiyalarının planlanmasında istifadə edilir. Oməliyyatdan öncə 10cu dəqiqədə indosianinin qandan təmizlənmə göstəricisi həsablanır. Oməliyyat vaxt1 çıxarılması planlanan qaraciyər payının qap1 elementlərinə sıxac qoyulur və xəstənin venasına $0,5 \mathrm{mg} / \mathrm{kg}$ dozada indosianin yaşıl boyası vurulur. Boya vurulmadan öncə və 1, 3, 5, 7, 10 dəq. sonra qanda boyanın konsentrasiyasına baxılır. Bu göstəricilərə 
əsasən portal elementlərin birtərəfli sıxıldığ1 halda boyanın 10-cu dəqiqədəki təmizlənmə faizi hesablanır. Oməliyyatdan öncəki 10-cu dəqiqədə təmizlənmə göstəricisinin, portal elementlərin birtərəfli sıxılması zamanı 10-cu dəqiqədə boyanın təmizlənmə göstəricisinə olan nisbəti hesablanır. Bu nisbətin 3-dən çox olması qalan qaraciyərin funksiyonal rezervlərinin çox az və əməliyyatdan sonrak1 dövrdə qaraciyər yetməzliyi baş vermə ehtimalının yüksək olduğunu göstərir. $\mathrm{Bu}$ xəstələrdə sıxac qoyulmuş bölgənin çıxarılamsı məsləhət deyildir. Rezeksiya həcmini azaltmaq və ya rezeksiya etməmək lazımdır. Omiliyyatönü/əməliyyatdaxili təmizlənmə nisbətinin 3-dən kiçik olduğu hallarda sıxac qoyulmuş bölgənin çıxarılması mümkündür.

Beləliklə, əməliyyatdaxili müaayinələrin nəticəsində aşağıdakı vaziyyətlər ola bilər:

1. Rezeksiya tələb edən xəstəlik və qaraciyər rezektabeldir. Bu halda rezeksiyanın növbəti mərhələsinəe keçilir.

2. Rezeksiya tələb etməyən xəstəliklərdə uyğun müalicə üsulu seçilir.

3. Rezeksiya tələb edən, lakin, yayğın olduğu və ya qaraciyər rezektabel olmadığ1 üçün rezeksiya oluna bilməyən hallarda rezeksiyadan imtina edilir. Metasttik adenokarsinomalarda qaraciyər arteriyasina kateter qoyulur və emeliyyatdan sonrakı dövrdə kimyaterapiya aparılır. Hepatosellular karsinomalarda isə əməliyyatdan sonrak1 dövrdə arteriyadaxili kimyaterapevtik embolizasiya tətbiq edilir.

\section{III mərhələ: Qaraciyərin sərbəstləşdirilməsi}

Bu marhəladə asas maqsad qaraciyərin çıxarlacaq bölgasini atraf toxumalardan ayıraraq yaraya asanliqla gəlməsini tə'min etməkdir.

Diğər orqanlarda olduğu kimi qaraciyər rezeksiyasında da sərbəstləşdirmə vacib mərhələdir. Bu mərhələdə qaraciyərin çıxarılacaq bölgəsinin bağları kəsilir, varsa ətraf orqanlarla bitişmələri ayrılır və çıxarılacaq bölgə ilə vücud arasında parenxima və damar əlaqəsi qalır.

Qaraciyər ilə ətraf toxumalar arasındakı iltihab mənşəli bitişmələr olduqda bunlar çətinlik törətmədən elektrokoter ilə ayrılırlar. Şiş invaziyası nəticəsindəki bitişmələr çətin ayrılır və bu xəstələrdə rezeksiya əks göstəriş olduğu üçün adətən lazım gəlmir. Lakin, bəzi hallarda, xüsusən əməliyyatdan öncəki biopsiya xətti üzrə invaziyalara rast gəlinir və bunların sağlam toxumalar səviyyəsində kəsilməsi məsləhətdir.

Bağların kəsilməsi qaraciyər rezeksiyası üçün çox vacibndir. Әvvəlcə girdə bağ bağlanaraq kəsilir. Bu bağın qaraciyər tərəfinə qoyulan ip tutacaq kimi istifadə edilə bilər. Ikkinci oraqvari bağ kəsilir. Oraqvari bağ kəsmədən qaraciyərin sağ və sol payları yetərli dərəcədə sərbəstləşə bilməz. Oraqvari bağda limfa kapilyarları vardır və bunlar periton ilə plevra arasinda kollteral rolu oynayaraq əməliyyatdan sonra 
hidrotoraksın baş verməsində rol oynayırlar. Ona görə də bu bağ1 dağlayaraq kəsmək lazımdır. Oraqvari bağ qaraciyərin "venozx yəhər" (bu bağın tac bağlara ayrıldığı yer) bölgəsinə qədər kəsilir. Yəhər bölgəsində qaraciyər venaları yerləşir və bə’zən venalar tac bağlarla yaxın təmasda olurlar. Ona görə də bu bölgədə ehtiyatla davranmaq, toxumaları incə, ayıraraq və görərək kəsmək lazımdır.

Üçüncü, çıxarılacaq tərəfin tac və üçbucaq bağları kəsilir. Tac bağları kəsərkən "yəhər" bölgəsində onların qaraciyər venaları, sağ tərəfdə isə aşağı boş vənə ilə yaxın təmasda ola biləcəyini və limfatik kapilyarlarla zəngin olduğunu unutmamaq lazımdır. Ona görə də onları ayırma texnikası vasitəsi ilə- disektorla altdakı toxumalardn ayırıb elektrokoterlə kəsmək lazımdır.

Qarciyər mediala doğru çəkildikdə sağ üçbucaq və tac bağlar daha bariz görünür. Sağ üçbucaq və arxa tac bağlar kəsildikdən sonra ön tac bağ aşağıdan başlayaraq "yəhərə” qədər kəsilir. Bu zaman qaraciyərlə aşağ1 boş vena arasındakı kiçik venalar bağlanıb kəsilə bilir. "Yəhər" bölgəsində bağlarla venalar arasında birləşmə sıx olduğu için bağ1 kəsməyə çalışmamaq lazımdır. Ogər qaraciyər venasını əvvəlcədən bağlamaq planı varsa, onda kəsiyi Qlisson kapsulından aparıb venanın qaraciyərdaxili hissəsini bağlamaq lazımdır. Qaraciyər venalarını parenxima kəsildikdən sonra bağlamağı tövsiyə edirik.

Sağ üçbucaq, tac və oraqvari bağlar kəsildikdən sonra qqaraciyərin să̆ payı yetərli dərəcədə sərbəstləşir və istənilən həcmli rezeksiya üçün şərait yaranır. Qaraciyər arxasındakı aşğı boş venaya açılan kiçik venaların bağlanıb kəsilməsi sərbəstləşməni daha da asanlaşdır.

Rezeksiya sol payda aparılacağı halda isə sol üçbucaq və tac bağların kəsilməsi şərtdir. Qaraciyər aşağıya və sağa çəkidikdə üçbucaq və tac bağlar bariz görünür. Ovvəlcə üçbucaq və varsa qaraciyər-qida borusu bağı, sonra tac bağlar "yəhərə” qədər kəsilir. Bu bağlar və oraqvari bağ kəsildikdən sonra II və III seqmentlər yetərli dərəcədə sərbəstləşir.

Qaraciyərin çıxarılacaq bölgəsi sərbəstləşdirildikdən sonra çıxarılacaq bölgə ilə vücud arasında parenxima və damar əlaqəsi qalır və əməliyyatın növbəti mərhələsinə başlanır.

\section{IV mərhələ: Mağistral damarlara nəzarət}

Bu morhalodo asas maqsad rezeksiya vaxtı baş verən qanaxmanı azaltmaq və asanlıqla nəzarət altına almaq üçün qaraciyərdə qan axınını dayandırmaqdır.

Qaraciyər ikili qan təhcizatına və zəngin damar toruna malik olduğu üçün parenximanı kəsərkən böyük və təhlükəli qanaxmalar baş verə bilir. Ona görə də qanaxmanın olmaması və baş verdikdə isə tezliklə dayandırılması qaraciyər rezeksiyasının ən vacib elementidir. 
Bu mərhələdə qaraciyərə gələn və qaraciyərdən çıxan damarlar nəzarət altına alınır. Lazım gəldikdə isə bu damarlar bağlanaraq və ya sıxılaraq rezeksiya xəttində qan dövranı dayandırılır. Nəticədə qnaxma azalır və qanayan damarın tutulub bağlanması və ya dağlanması üçün əlverişli şərait yaranır.

Qaraciyərdə qan dövranın tam, natamam və bölgəsəl şəkildə dayandırılması üsulları vardır. Tam dayandırmada qaraciyərə gələn və çıxan damarların hamısı sıxılaraq bütünqaraciyərdə qan dövranı dayandırılır. Natamam dayandırmada yalnız qaraciyərə gələn damarlarqap1 venası və qaraciyər arteriyası sıxılaraq (Pringler üsulu) qaraciyərə qangəlimi müvəqqəti olaraq kəsilir. Bölgəsəl dayandırılmada isə çıxarılacaq bölgəya gələn və çıxan damarlar bağlanır.

Qaraciyərdə qan dövranını tam dayandırmaq üçün qapı venası, qaraciyər arteriyası və venaları ayrılaraq sərbəstləşdirilir və nəzarət altına alınır. Qap1 elementlerini nəzarət altına almaq üçün sol əlin göstərici barmağı Vinslav dəliyinə daxil edilir, baş barmaqla arteriya, vena və axacaq üçlüyü müəyyən edilir. Üçlüyün sol tərəfində qaraciyər-mə'də bağı damarsız yerdən deşilir və buradan qaytan keçirilərək qapı üçlüyü asqıya alınır.

Qaraciyər venalarını nəzarətə almaq üçün oraqvari, sağ və sol tac bağlar kəsilərək "qaraciyərin çıxışına-"yəhərə" çatılır. Burada venaları iki yolla- ekstra- və intrahepatik üsullarla səbəstləşdirmək olar. Ekstrahepatik sərbstləşdirmədə bağlar çox ehtiyatla və incə ayırma texnikası ilə altdakı venalardan ayrılaraq kəsilir. Venaların ekstrahepatik hissələri çox kiçik $(0,5-1,5 \mathrm{sm})$ və bağlarla six təmasda olurlar. Sol və orta venalar əksər hallarda çoxışda birləşərək bir vena şəkilində boş venaya açılırlar. Ona görə də əksər hallarda ekstrahepatik olaraq iki vena-sağ və birləşmiş sol-orta venalar müşahidə edilir. Qaraciyər venaları incə divarlı və bağlarla sıx bitişməli olduğu için ayrılma vaxtı asanlıqla zədələnə bilirlər. $\mathrm{Bu}$ isə təhlükəli qanaxmalara və hava emboliyasına səbəb ola bilir. Bə'zi hallarda isə bu bölgədə şiş və iltihabi bitişmələr olduqda venaların ekstrahepatik sərbəstləşdirlməsi mümkün olmur. Bu səbəblərə görə təhlükəsi az olan intrahepatik üsula üstünlük verilir. İntrahepatik üsulda qaraciyər çıxışına yaxın yerdə Qlisson kapsulu kəsilir, ayırma texnikası ilə parenxima içərisində venalar tapılır. Sərbəstləşdirilmiş venalar qaytanla asqıya alınır.

Qaraciyərə gələn və çıxan damarlara asq1lar qoyulduqdan sonra lazım olan vaxt qaraciyərdə qan dövranını dayandırnaq olar. Bunun üçün əvvəlcə qap1 elementlərinə, sonra isə qaraciyər venalarına əzməyən sixaclar qoyulur. İşəmik zədələnməni azaltmaq üçün 10 dəq sonra sıxaclar açılır. Lazım gəldikdə 5 dəq sonra sıxaclar təkrar qoyula bilir. $\mathrm{Bu}$ şəkildə, 10 dəq. işemiya (qansızlazdırma), 5 dəq reperfuziya (qanlandırma) bir neçə dəfə təkrar edilə bilər. Bə’zi tədqiqatçılar qaraciyərin toplam 60 dəq qədər qansızlaşdırmaya davam gətirdiyi bildirilir. 
Qan döranını tam dayandırma üsulu qaraciyər əməliyyatlarında qanaxmanı dayandırmaq üçün ən effektiv üsuldur. Lakin bu üsulun çox ciddi əksik cəhətləri vardır. Bu üsul qaraciyərin qalacaq hissəsində işemiya törədir. Qaraciyər venalarını sərbəstləşdirmək bir tərəfdən əməliyyat müddətini artırır, diğər tərəfdən təhlükəli ağırlaşmalar (qanaxma, emboliya) törədə bilir. Ona görə də tam dayandırma üsulu hazırda geniş istifadə olunmur və biz də bu üsulu tövsiyə etmirik.

Natamam dayandırma üsulunda yalnız qapı üçlüyü nəzarətə alınır və qaraciyər venalarına müdaxilə edilmir. Yuxarıda göstərildiyi kimi qap1 elementleri qaytanla asq1ya alınır və rezeksiya vaxtı əzməyən damar sıxıcısı ilə sıxılır. 10 dəq. qansızlaşdırma, 5 dəq qanlandırma tətbiq edilir. Pringlər üsulu qaraciyərdə qan dövranını ciddi şəkildə azaldır və qap1 damarlarından baş verən yuksək təzyiqli qanaxmanı dayandırmaq üçün çox effektivdir. S1xmaya baxmayaraq qanaxma davmam etməsi qanaxmanın qaraciyər venalarından olduğunu göstərir. Qaraciyər venalarında qapaq olmadığı üçün aşağı boş venadan retroqrad qan axını baş verir və bu qanaxmaya səbəb olur. Bu qanaxmalar zəif təzyiqli qanaxmalardır və adətən qaraciyər toxumasına zəif təzyiq ilə dayandırmaq olur. Qaraciyərdə işəmiya törətməsi və retroqrad qanaxmanı dayandıra bilməməsi bu üsulun mənfi cəhətidir. Lakin, asan yerinə yetirildiyi, yüksək təzyiqli və böyük qanaxmaları dayandırmada yararlı olduğu üçün ən geniş yayılmış üsuldur.

Təcrübəmizdə Pringler üsulu aşağıdakı şəkildə istifadə edilir. Qaraciyər rezeksiyası vaxtı bütün xəstələrdə qaraciyər "qap1 üçlüyü” qaytanla asq1ya alınır. Sıxacın qoyulmasını isə bütün xəstələrdə yox aşağıdakı hallarda tövsiyə edirik:

* $\quad$ rezeksiya vaxtı qanayan daamarı tapıb bağlamaq üçün

* diffuz kapilyaar qanaxmalarda qaraciyər səthini effektiv koaqulyasiya etmək üçün

* $\quad$ sirrozlu xəstələrdə parenximanı kəsmək üçün əzmə üsulu tətbiq edildiyi hallarda.

Göstərişə görə istifadə etməklə üsulun işemiya törətmə imkanları minumuma endirilir

Bögəsəl dayandırma üsulu əslində qaraciyər rezeksiyasının, xüsusən də seqmentektomiya və daha böyük əməliyyatların mütləq komponentidir. Çünki, qaraciyər qaraciyər parçasını çıxarmaq üçün parenximanın kəsilməsi ilə yanaşı ayaqcı̆̆ın da bağlanıb kəsilməsi şərtdir. tam və natamam üsullardan fərqli olaraq bu üsul müvvəqqəti yox daimidir, qalan qaraciyərdə işemik zədələnmə törətmir və ç1xarılacaq bölgənin sərhəddlərini dəqiq müəyyən etməyə imkan verir. Lakin bu üsul rezeksiya xəttində qan axınını və qanaxmanı tam dayandırmır, çünki qarşı tərəfdə qan axını mövcuddur. Bu üsulun texnikası irəlidə "damar ayaqcı̆̆ının bağlanması" bölümündə veriləcəkdir.

V mərhələ: Damar-axacaq ayaqcıqlarının bağlanması 
Bu marhalado asas maqsad çıxarlacaq bölgənin asas damar və axacaqlarının bağlayıb kəsməkla, bu bölgəni qalan qaraciyərdən ayırmaq va qan dövranını kasməkdir.

Çıxarılacaq bölgə ətraf orqanlardan ayrılıb sərbəstləşdirildikdən sonra orqanizmlə iki əlaqəsi qalır: damar-axacaqlarla (DA) və parenxima ilə. Hansının- , parenximanın yoxsa damar -axacaq əlaqəsinin ilk növbədə kəsilməsindən asılı olaraq müxtəlif üsullar var.

Qərb cərrahlarının istifadə etdiyi üsulda qapı eleməntləri və qaraciyər venaları bağlanıb kəsildikdən sonra parenxima kəsilir. Bu üsulun müsbət cəhəti odur ki, damarlar bağlandığı üçün qanaxma nisbətən az olur, lakin tam dayanmır. Çünki, qalan qaraciyərdə qan dövranı dayandırılmamışdır. Diğər tərəfdən damarların bağlanması ilə əlaqədar qansızlaşan bölgənin rəngi dəyişir və sərhəddləri dəqiq müəyyən olunur. Mənfi cəhəti isə odur ki ayaqciqların, xüsusən də venaların sərbəstləşdirilməsi texniki çətinlik törədir, və əməliyyat müddətini uzadir.

İkinci üsul şərq (Yaponya, Çin) cərrahları tərəfindən geniş istifadə olunur və əvvəlcə parenxima, sonra isə DA ayaqcı̆̆ı kəsilir. Bu üsulun müsbət cəhəti odur ki, parenxima kəsildirkdən sonra damar və axacaqlar ortaya çıxır və asanlıqla bağlanıb kəsilir, əməliyyat müddəti qısa olur. Həm qalan həm də çıxarılan parçalarda işemiya törənmədiyi üçün bu üsul canlıdan qaraciyər köçürülməsində əlverişlidir. Lakin bu üsulda qanaxma yüksək olur və adətən bütöv qansızlaşdırmaya ehtiyac duyulur. Bundan başqa çıxarılacaaq anatomik bölgənin sərhəddləri dəqiq müəyyən olunmur. Damarlar bağlandıqdan sonra qansızlaşmış bölgələr ortaya çıxarsa təkrar rezeksiya edilməsi lazım gəlir.

İstifadə və tövsiyə etdiyimz üçüncü üsulda isə aşağıdakı ardıcıllıq yerinə yetirilir: əvvəlcə çıxarılacaq bölgənin “qapı üçlüyü” bağlanıb kəsilir, sonra parenxima kəsilir, ən axırda isə qaraciyər venaları bağlanıb kəsilir. Beləliklə həm çıxarılacaq bölgənin sərhəddləri dəqiq müəyyən olunur, həm qanaxma nisbətən azaldılır, həm də qaraciyər venası təhlükəsiz və asanlıqla tapılaraq, əməliyyat müddəti qisaldılır.

DA ayaqcıqlarının düzgün bağlanması üçün aşağıdakı anotomik cəhətləri unutmamaq lazımdır:

* Qap1 venas1, qaraciyər arteriyası və öd axacaqlar1 qaraciyər daxilində ayr1-ayrı şəkildə yox, Glisson kapsuludan əmələ gəlmiş ümümi bir q11ıf içərisindədirlər. Ona görə də bu üç element birlikdə bağlana bilirlər.

* Qaraciyərdaxili qap1 DA ayaqciqları qaraciyərə boylama və perpendikulyar istiqamətdə olub visseral səthə yaxın yəeləşirlər.

* Qaraciyər venaları qaraciyərə köndələn istiqamətdə olub diafraqmatik səthə yaxın yerləşirlər, qılıfları yoxdur və asanlıqla zədələnə bilirlər.

Payların qapı ayaqciqlarının ayrılması

Sağ və sol qapı üçlüyünün ayrılması ekstrahepatik və intrahepatik üsullarla ola bilir. 
Ekstrahepatik ayırma üsulunda qaraciyər-12-barmaq bağının ön səhifəsi damar damar və axacaqlardan ayrilır. Qaraciyərə yaxın yerdə arteriya, axacaq və venanın sağ və sol şaxələri tapılır. Burada unutmamaq lazımdır ki, ən erkən arteriya sonra axacaq, qaraciyərə ən yaxında isə qap1 venası sağ və sol şaxələrə ayrılır. Rezeksiya olunacaq tərəfin damar və axacaqları ayrı ayrılıqda bağlanıb kəsilir. Bu üsulun müsbət cəhəti odur ki, şaxələr gözlə görünərək dəqiq bağlanıb kəsilir. Lakin, üsulun bir çox mənfi cəhəti də vardır. Qapı elementlərinin ayrılması əməliyyatı uzadır, xüsusən, sirrotik xəstələrdə qaraciyər qpısında zəngin kollateralları ayırmaq və kəsmək üçün üzun zamantələb olunur. Diğər tərəfdən əlavə qaraciyər arteriyası olan anomaliyalarda, bu arteriyaların bağlanmaması rezeksiya vaxtı qanaxmaya səbəb ola bilir.

Intrahepatik ayırma üsulu nisbətən sadə, lakin təcrübə tələb edən üsuldur. Qaraciyər qapısından 1-1,5 sm yuxarıda Qlisson kapsulu və qapıya paralell 2-2,5 sm kəsilir. Göstərici barmaq buradan qaraciyər parenximasına daxil edilir və qapı arxasında baş barmaqla qarşılaşdırılır. Parenxima iki barmaq arasında əzildikdə qapı ayaqcı̆̆ı müəyyən edilir. Üç qap1 elementi qaraciyər daxilində ümumi q1lıfda olduğu üçün barmaqla qaytan şəkilində hiss edilir. Sağ payın qapı qayaqcı̆̆ı nisbətən dərində və q1sa $(0,6-1,5 \mathrm{sm})$ olub tezliklə sektoral-seqmentar şaxələrə ayrilır. Sağ hemihepatektomiyalarda əvvəlcə xolesistektomiya edildiyi üçün sağ qapı ayaqcığına öd kisəsi yatağından da müdahilə etmək olar. Sol payın qapı ayaqcığ 1 isə solda və səthə yaxın olub daha uzundur (4-6 sm) və girdə bağ çuxurunda seqmentar şaxələrə ayrılır. Tapılmış ayaqcıq qaytanla asqıya alınır və parenximadan daha geniş ayrılır. Sonra ayaqcığa sıxac qoyuluraq 2-3 dəq gözlənir və qaraciyərdə rəng dəyişikliyinə baxılır. Rəngi dəyişən anatomik bölgəyə görə hans1 ayaqcığın sıxıldığı dəqiqləşdirilir. Rəng dəyişikliyi orta yarıqdan hansı tərəfdə baş verirsə, bu eyni tərəfin ayaqcığının sıxıldığını göstərir. Bu dəqiqləşdirmə işləmindən sonra ayaqcıq 01-02 saylı sorulmayan iplə bağlanaraq kəsilir.

Bəzən sağ ayaqcıq sıxıldıqda IV seqmentdə də rəng dəyişikliyi baş verir. $\mathrm{Bu}$ anomaliya olaraq IV seqment saxəsinin sağ ayaqcıqdan ayrıldığını göstərir. Belə halda sağ ayaqcıq daha distaldan sıxılıb təkrar baxılır. Ogər IV seqmentdə rəng dəyişikliyi təkrar baş verirsə onda sağ ayaqcığın bağlanıb kəsilməsi parenxima kəsildikdən sonraya saxlanılır. Parenxima kəsildikdən sonra sağ payın seqmentar şaxələri ayrı-ayrılıqda bağlanıb kəsilir, IV seqmentin saxəsi qorunur.

$\mathrm{Bu}$ üsul təcrübə tələb etsə də (barmaqla ayaqcığı hiss etmə və dərinlik hissi) tez olduğu, hər üç element birlikdə tapıldığı üçün geniş istifadə edilir. Diğər tərəfdən arteriya anomaliyalarında da bu üsul faydalıdır. Ö̈̈nki, əlavə arteriyalar da ümumi q1lifin içində olurlar.

Seqmentlarin qap ayaqciqların ayrlmast.

I seqment qapı təhcizatını adətən sol qapı ayaqcığından bir və ya bir neçə şaxə ilə alır. Venoz axını isə kiçik venalarla birbaşa aşağı boş venaya 
açılır. Ona görə də bu seqmentin ayaqcı̆̆ını parenximanı kəsmədən tapıb bağlamaq çox çətindir.

II seqmentin qapı ayaqcı̆̆ını tapmaq üçün girdə bağ çuxurunda sol qap1 ayaqcı̆̆ını ayırmaq lazımdır. Girdə bağ qaraciyər daxilində sol qapı venasının II, III və IV seqmentlərə şaxələndiyi yerə birləşir. Girdə bağın parenximada gedişi izlənir və birləşdiyi yer parenximadan küt üsulla ayrılır. II seqmentin şaxəsi girdə bağdan solda, III seqment şaxəsindən arxada yerləşir. III seqment şaxəsi də bağdan solda, lakin, visseral səthə yaxın və öndə yerləşir. IV seqment şaxəsi isə üçüncününkü ilə eyni səviyyədə lakin bağdan sağda yerləşir. Bir çox hallrda II seqmentə bir yox bir neçə qapı şaxəsi daxil olur. Ona görə də bağlanıb kəsmədən əvvəl rəng dəyişmə sınağının aparılması tövsiyə olunur.

III seqmentin qap1 ayaqcığı visseral səthə yaxın və öndə olduğu üçün ikinci seqmentinkinə nəzərən daha asan tapılır. Bu seqmentin şaxəsi IV seqment şaxəsinə yaxın olduğu üçün səhvən hər ikisi də bağlana bilər. Buna yol verməmək üçün III seqment şaxəsini həmişə bağın sol tərəfində axtarmaq və bağlamadan əvvəl rəng dəyişmə sınağı aparılmalıdır.

II və üçüncü seqmentlərin şaxələri bir-birinə yaxın olduqları üçün tapılıb ayrılıqda bağlanmaları çox vaxt çətinlik törədir. Ona görə də ya hər iki seqment birlikdə çıxarılır, ya da ayaqcığın bağlanması parenximanın kəsilməsindən sonra yerinə yetirilir.

IV seqmentin qapı ayaqcı ğı III seqmentin şaxəsi ilə eyni sviyyədə girdə bağın qapı venasına birləşdiyi yerdən ayrılır və sağa doğru istiqamətlənir. IV seqment ayaqcığını tapmaq üçün girdə bağın sağ tərəfi parenximadan ayrılır. Burada sol qapı ayaqcı̆̆ı da ortaya çıx bilər. IV seqment şaxəsi sol qapı ayaqcı̆̆ından öndə və yuxarıda yerləşir. Rəng dəyişmə sınağı seqment ayaqcığının tapılmasında köməkci ola bilər. Lakin seqmentin bir neçə şaxəsi olarsa bu sınaq düzgün nəticə verməyə bilər.

IV seqment ayaqcığı yerinə səhvən sol qapı ayaqcığı, III və IV saxalər birlikdə bilər ki, bu da II və III seqmentlərdə nekroz törədər. Bu səhvlərə yol verməmək üçün sol qapı ayaqcığını parenximadan kifayət dərəcədə ayırmaq, sübhəli hallarda isə ayaqcığın bağlanmasını parenxima səsilməsindən sonraya saxlamq lazımdır. Ümumiyyətlo, IV seqmentin rezeksiyalarında qapı ayaqcı̆̆ının parenximadan ayrılması vo nozarat altına alınması tövsiyo olunur. Bu hom qanaxmanı asanlıqla nəzarat altına almă̆a həm də səhvliklərə yol verməmək üçün lazımdır.

Sağ paydakı seqmentlərin qap1 ayaqciqlarının tapılması sola nəzərən daha çətindir. Çünki, sağ seqmentar şaxələr daha dərində yerləşir və nisbətən q1sadırlar. Sağ paydakı seqmentlərin (V, VI, VII və VIII seqmentlər) qapı ayaqcıqlarını iki üsull tapmaq olar: barmaqla qaraciyərə daxil olub parenximanı əzərək tapma; parenximanı kəsdikdən sonra görərək bağlama.

Sağ qap1 şaxəsinin intrahepatik yolla tapılmasında olduğu kimi, qap1 üzərində kapsul 2-3 sm kəsilir, barmaqla qaraciyər toxumasına daxil olunur, sağ tərəfdə parenxima iki barmaq arasında əzilir. Sağ qap1 ayaqcı̆̆ı və şaxələndiyi yeri barmaqla parenximadan ayrılır. Bundan 
sonra şaxənin istiqamətinə və reng dəyişikliyi sınağına görə sektoral və seqmentar şaxələr müəyyən olunur.

Sağ orta sektorun ayaqcı̆̆ı qisa olub yuxarıya doğru gedir və önə V seqmentə, arxaya isə VIII seqmentə şaxələnir. Sağ yan sektorun ayaqcı̆̆1 uzun olub sağa və aşağıya doğru gedirək önə VI seqmentə, arxaya VII seqmentə şaxələnir.

Sağ payın seqmentlərinin qap1 ayaqcıqlarının tapılıb bağlanmaları zamanı bir çox çətinliklər və ağırlaşmalar baş veriə bilir. Sirrozda parenximanın əzilməsi çətinlik törədir, çoxlu qanaxmaya səbəb ola bilir. VI və VII seqmentlərin öd axacaqları sorta sektorun ayaqcığını soldan və arxadan dolandığı üçün ("Hjortsjo qarmağı") orta sektor ayaqcı̆̆ının bağlanması vaxtı bu axacaq da bağlana bilər.

Bu çətinliklərlə qarşılaşmamaq və ağırlaşmaları azaltmaq üçün sağ payın seqmentar ayaqcıqlarını parenxima kəsildikdən sonra bağlamaq daha məqsədəuyğundur.

Beləliklə, bu mərhələdə ç1xarılacaq bölgənin qapı venası, qaraciyər arteriyası və öd axacağından ibarət üçlü qapı ayaqcığı tapılıb bağlanaraq yerli qan dövranı dayandırılır. Bu, çıxarılacaq bölgənin sərhəddlərini dəqiq müəyyən etməyə və parenximanı kəsərkən qanaxmanı azaltmağa şərait yaradır. Să̆ və sol payların qapı ayaqcıqları ekstrahepatik yolla qaraciyər-12 barmaq bağırsaq bağında və ya intrahepatik yolla qap1 ətrafındakı parenximanı barmaqla əzərək tapılıb bağlanırlar. II, III və IV seqmentin qap1 ayaqcıqları girdə bağ çuxurunda, V, VI, VII və VIII seqmentin ayaqcıqları isə öd kisəsi yatağına və ya qapıya yaxın bölgədə intrahepatik yolla tapılıb bağlanır. Qapı ayaqcıqlarını bağlayıb kasmadon avval rong dayişmo sină̆ ila ayaqcĭ̆ın doğru tapıldı̆̆ını dəqiqloşdirmək lazımdır. Ayaqcığın axtarılması texniki çətinlik töradarso, onun axtarılması va bă̆lanması parenximanı kasdikdan sonra yerina yetirilmalidir

VI marhələ: Parenximanın kəsilməsi

Bu marhəladə asas maqsad çıxarllacaq qaraciyər bölgasi ila qalan qaraciyər arasındakı əlaqəni kəsmək, kiçik damar və axacaqları bağlamaqdır.

Çıxarılacaq bölgə müəyyən edildikdən, ətraf toxumalardan sərbəstləşdirildikdən, qanaxmaya nəzarət üçün bütöv qansızlaşdırmaya hazırlıq gördükdən, qap1 ayaqcığı bağlanıb kəsildirkdən və sərhəddlər dəqiqləşdirildikdən sonra onu qalan qaraciyərdən ayırmağa başlanılır. Çıxarılacaq qaraciyər parçası qalan qaraciyərə parenxima, intrahepatik qapı damarları, axacaqlar və qaraciyər venaları ilə bağlıdır.

Qaraciyər toxuması qapı elementləri və qaraciyər venalarından təşkil olunmuş müxtəlif diametrli damar torunndan və bunlar arasında yerləşən hepatosit kütləsindən ibarətdir. Hepatosit kütləsi kövrək oldüğu üçün asanlıqla ayrılır. Damar-axacaq torunun kəsilməsi isə qanaxma və öd 
s1zmas1 törədir. Ona göro do parenximanın kosilmosi oslindo qaraciyordaxili damar vo axacaqların bağlanmast vo kosilmosi omaliyyatıdır.

Ovvəlki bölümdə qeyd edildiyi kimi qaraciyər paernximasını kəsmək üçün dğlama (lazer, plazma, elektrıkoter, arqonlu koter), ayırma (digitoklaziya, alətlə əzmə, ultrasəs bıçağı, su şırnağı, sorucu bıçaq) və s. müxtəlif kimi üsullar mövcuddur. Hazırda ən geniş istifadə olunan üsullar ayırma prinsipinə əsaslanan üsullardır. $\mathrm{Bu}$ üsullarda qaraciyərdaxili damar və axacaq elementləri parenximadan ayrılıb sərbəstləşdirildikdən sonra bağlanıb kəsilir.

Təcrübəmizdə istifadə etdiyimiz iki ayırma üsulunun -alətlə ezmə və ultrasəs bıçağının tətbiqi haqqında mə'lumat verəcəyik.

Әzmə üsulu

Qlisson kapsulu elektrokoaqulyator isə kəsildikdən sonra s1xıcı alətlə qaraciyər toxuması əzilərək içərisindəki damarlar sərbəstləşdirilməyə çalış1lır. Bunun üçün ücü 2-3 sm olan əyri tipli dişsiz sıxıcılar istifadə edilə bilər. Qaraciyər toxuması s1xıcının ayaqları arasına kəsik xəttinə paaraləll olaraq alınır və sıxıcı sıxılaraq toxuma əzilir. Sıxıcının yerini yaraya köndələn istiqamətdə 2-5 mm dəyişərək əzmə təkrarlanır. Nəticədə parenxima əzilir, $1 \mathrm{~mm}$-dək kiçik damarlar qurılır, bundan böyük damar və axacaqlar isə zədələnmirlər . Sorucu alət vasitəsi isə yaradakı parenxima parçaları və qan təmizləndikdə parenximadan ayrılmış damarlar sərbəst şəkildə ortaya çıxır. Bu damarlar tutulur, hər iki tərəfdən bağlanır və kəsilir. Bu işləm, yə’ni "əzmə $\rightarrow$ sorma $\rightarrow$ bağlama $\rightarrow$ kəsmə" prosesi addım-addım yerinə yetirilərək çıxaarılacaq parça tam ayrılana qədər davam etdirilir. Hemostaz normal olduqda zədələnən kiçik damar və kapilyarlardan baş verən qanaxma özözünə durur. Parenxima içərisinə qaçan və qanaxma törədən böyük damarlar eyni üsulla parenximadan ayrılarq tapılıb bağlanır.

Ultrasas bıçă̆l

Ultrasəs bıçağı qaraciyər cərrrahiyyəsinin inkişafinda mühüm rol oynamışdır. $\mathrm{Bu}$ üsulun tətbiqi sayəsində qaraciyər rezeksiyasının təhlükəsi xeyli azalmış, və istənilən həcimdə rezeksiyalar aparmaq mümkün olmuşdur. Ulrtasəs bıçağı ilə parenximanın kəsilməsində CUSA (Cavitron Ultrasonic Surgical Aspirator, Surgical Technology Group, USA) cihazından istifado edilmişdir. Bu alətin 3 prosesi (kavitasiya, irriqasiya və aspirasiya) eynimomentli həyəta keçirməsi sayəsində qaraciyərdaxili damarlar və axacaqlar parenximadan ayrilır və sərbəstləşir. Kavitasiya nəticəsində həssas parenxima hüceyrələri destruksiyaya uğrayır, irriqasiya ilə kavitasiya üçün şərait yaranır və zədələnmiş toxumalar yuyulur, aspirasiya isə zədələnmiş toxumaları və qan1 rezeksiya xəttindən təmizləyir. $\mathrm{Bu}$ proseslər nəticəsində parenximadan ayrılaraq sərbəstləşən intrahepatik damar və axacaqlar tutulur, sapla bağlanaraq kəsilir.

Parenximanın kasilmasi metodikası

Parenximanı kəsərkən aşağıdakı qaydalara əməl etmək lazımdır: 
* Oməliyyat vaxtı qaraciyər toxumasını az travmaya uğratmaq və qanaxmaya yol verməmk lazımdır.

* Mümkün qədər anatomik rezeksiyalar aparılmalı, qansız, nekrotik toxumalar qalmamalıdır. Bu əməliyyat vaxtı və sonrası ağırlaşmaların profilaktikası üçün əhəmiyyatlidir.

* Kəsik qaraciyər venalarında 1 sm kənardan aparılmalıdır. Venaların zədələnməsi təhlükləli qanaxmalara və hava emboliyasına səbəb ola bilər.

* Residivi azaltmaq üçün parenxima şiş toxumasından on az $1 \mathrm{sm}$ kənarda sağlam toxuma səviyyəsində kəsilməlidir.

$\mathrm{Bu}$ qaydalar aəməl etmək surətiylə parenximanın kəsilməsi prosesinə başlanılır. $\mathrm{Bu}$ işləm aşağıdakı ardıcıllıqla aparılır: rezeksiya sarhaddlarinin to'yin edilmasi, Qlisson kapsulunun kasilmasi, parenximadaxili damar vo axacaqların ayrılması, bağlanıb kasilməsi, qanaxmaya nəzarət, qaraciyər venalarının bağlanıb kəsilməsi və parçanın çıxarılmast.

Parenximanı kəsmədən əvvəl çıxarılacaq bölgənin sərhəddləri müəyyən olunmalıdır. Bu iki üsulla tə’ yin edilir. Qapı ayaqcığı bağlı olduğu halda rengi dəyişmiş bölgə ilə normal bölgə arasındakı xətt çıxarılacaq bölgənin sərhəddini göstərir. Qapı ayaqcığı bağlı olmadığı hallarda isə sərhəddi tə' yin etmək üçün qaraciyərin cərrahi anatomiyası nəzərə alınır. Mə'lumdur ki, qaraciyər venalarının proeksiyası pay, sektor və seqmentlərin sərhəddlərini müəyyən etməkdə əsas istiqamətvəricidir. Qaraciyər venalarının yerini dəqiq tə’yin etmək üçün əməliyyatdaxili USM istifadə edilir. USM olmadıqda isə təxmini xətlərə görə (məsələn, orta vena aşağı boş venadan öd kisəsi yatağına çəkilən xətt üzrə yerləşir) müəyyən olunur.

Ç1xarılacaq bölgənin sərhəddləri müəyyən edildikdən sonra kəsik xəttinin yeri tə’yin edilir. Kəsik xətti qaraciyər venasından çıxarılacaq bölgəyə doğru $1 \mathrm{sm}$, şişdən sağlam toxumaya doğru isə ən az $1 \mathrm{sm}$ uzaqlıqda aparılmalıdır.

Müəyyən olunmuş kəsik xətti üzrə Qlisson kapsulu elektrokoaqulyatorla 1-2 mm dərinlikdə kəsilir. Ozmə və ya ultrsəs bıçağı ilə parenximadaxili damar va axacaq elementleri sərbəstloşdirilorək bağlanıb kəsilir. $\mathrm{Bu}$ işləm addım-addım yerinə yetirilir və parenxima tam kəsilənə qədər davam etdirilir. Qaraciyərin aşağı boş venaya bitişik olan arxa səthi də əzmə və ultrasəs üsulu ilə ayrılır və burada rast gələn kiçik venalar bağlanıb kəsilir.

Damarlar kliplə və ya iplə bağlana bilər. Bunun üçün elektrokoaqulyatorun istifadə edilməsini məsləhət görmürük. Yara kənarlarının yanlara doğru zəif çəkilməsi yaranın daha yaxşı görünməsi, ayırma, bağlama və kəsmə işləri üçün əlvərişli şərait yaradır.

Böyük damarlardan və ya yeri tapılmayan qanaxma yox isə Pringler işləminə ehtiyac qalmır. Qırılaraq parenxima içinə qaçan və qanayan damarların yerini tapmaq üçün sorucu ilə yara qandan aktiv təmizlənir. 
Damarın tutulub bağlanması mümkün deyilsə ətrafı parenximadan ayrıldıqdan sonra tutulub bağlanır. Qanaxma güclü olduğu hallarda Pringler işləmi yerinə yetirilir. Әgər, bu işləmdən sonra qanaxma dayanmazsa, qaraciyər venalarında zədələnmə olduğu düşünülməlidir. $\mathrm{Bu}$ qanaxmalar yara kənərına zəif təzyiq vasitəsi ilə dayana bilir. Qanaxma dayandıqdan sonra həmin bölgə ətraf parenximadan ayrılır və qanaxan damar tapılıb bağlanır.

Parenximanı kəsərkən qaraciyər venalarına diqqət edilməlidir. Venalar adətən diafraqmal səthə yaxın yerləşirlər və aşağı boş venaya yaxın yerlərdə daha bəlirgindirlər Qapı elementlərindən fərqli olaraq venaların ətrafinda q1lıf yoxdur və divarları nazik olduğu üçün asanlıqla zədələnə bilirlər. Ona görə də bunları parenximadan ehtiyatla ayırıb bağlamaq lazımdır. Çıxarılacaq bölgənin venasını aşağı boş venaya qədər sərbəstləşdirmk lazım deyil. Onu boş venaya yaxın ancaq parenxima içərisində bağlamaq daha təhlükəsizdir. Qapı ayaqcığının parenxima kəsilməsindən öncə bağlanmadığ 1 hallarda qaraciyər venasını bağlamdan əvvəl qapı ayaqcığı bağlanmalıdır. Qapı ayaqcığı qaraciyərin visseral səthinə və mərkəzə yaxın yaxın yerləşir.

Parenxima, parenximadaxili damar və axacaqlar, qap1 ayaqcığı və qaraciyər venası kəsildikdən sonra qaraciyər parçası qalan qaraciyərdən tam ayrılır və yaradan çıxarılır.

Belalikla, bu marhalada rezeksiya sarhaddlari ta'yin edilir, Qlisson kapsulu kəsilir, parenximadaxili damar və axacaqlar sərbəstloşdirilarək bağlanıb kasilir, qanaxma dayandırılır, qaraciyar venaları sarbastlaşdirilarək parenximadaxili hssado bağlanıb kasilir va parça çlxarllır.

\section{VII mərhələ: Yara səthinin təvtişi}

Bu mərhaladəasas məqsad əməliyyat vaxtı buraxılan səhvlari aşkar emək va aradan qaldırmaqdir.

Bu mərhələdə qalan qraciyərdə qanaxma, öd sızıntıs1, nekrotik toxuma, venoz axının vəziyyətində dəyişiklik, yerdəyişmə və ətraf orqanlarda zədələnmə olub-olmadığı yoxlanılır.

Rezeksiya səthindən qanaxma iki başlıca səbəbdən ola bilər: kapilyar qanaxma; böyük damarların yetərli bağlanmaması və ya liqaturanın çıxması. Ayırma texnikasına əsaslanan mövcud rezeksiya üsulları adətən 1-2 mm-dən böyük damarları sərbəstləşdirməyə və bağlamağa imkan verir. Bu ölçüdən kiçik, xüsusən də kapilyar damarlar adəəən qırılır və bağlana bilmir. Laxtalanma sistemi normal olan hallarda kapilyar damarlarda əmələ gələn tromblar qanaxmanın dayanmasını tə'min edirlər. Lakin, hipokoaqulyasiyası olnan xəstələrdə tromb əmələ gəlməsində və ya lizisindəki pozulmalar nəticəsində kapilyar qanaxma davam edə bilir. Kapilyar qanaxma yara səthində difuz, "bulaq kimi 
qaynama" şəkilində olur. Az təzyiqli olmasına baxmayaraq buqanaxma çətin durduğu və diffuz olduğu üçün çoxlu miqdarda qanitirməyə səbəb ola bilir.

Kapilyar qanaxmanı dayandırmaq üçün Pringler manevrası ilə qanaxma azaldılır, rezeksiya səthi qurudulur və koaqulyatorla incə təbəqə şəkilində dağlanır. Ogər bu fayda verməzsə, lokal hemostatikler (trombin süngərləri, fibrin yapışqanları və s) istifadə olunur. Buimkanlar olma1qda isə rezeksiya səthi tamponada edilir və 24-48 saat sonra relaparatomiya edilərək tamponlar çıxarılır. Kapilyar qanaxmada yerli tədbirlərlə yanaşı laxtalanma sistemindəki pozulmaları korreksiya etmək mühüm şərtdir. Laxtalanma faktorlarının köçürülməsi, YDDL sindromunda isə bununla yanaşı heparin verilməsi ən vacib tədbirlərdəndir.

Yetərli bağlanmama və liqaturanın çıxması nəticəsində nisbətən böyük damarlardan baş verən qanaxmaları dayandırmaq üçün qanaxan damar tapılb bağlanır.

Öd sızması öd axacaqlarının zədələnəmsi, kəsilən axacaqların yetərli bağlanmaması nəticəsində baş verir. Öd aacaqlarında sızmanın olubolmasığını yoxlamaq üçün "hava qabarcı̆ğ sınağı” aparılır. Oməliyyat gölgəsinə fizioloji məhlul doldurulur və qalan qaraciyərin rezeksiya səthi məhlul içərisində tutulur. İncə iynə ilə xoledoxa hava vurulur və kəsik səthi müşahidə edilir. Hava qabarcıqlarının çıxaması bağlanmamış od yolunu göstərir. $\mathrm{Bu}$ yer tapılıb bağlanır. Anatomik olmayan, texniki cəhətdən çətin və sirrotik qaraciyaərlərdə aparılan rezeksiyalarda öd sızmasına daha çox diqqət edilməlidir.

Qalan qraciyərdə görünən hər tərəfinə diqqətlə baxılaraq rəngini dəyişmiş bölgələr olub-olmadığı yoxlanılır. Bu bölgələr çıxarılmadıqda nekrozlaşaraq infeksiya və intoksikasiya mənbəyinə çevrilirlər. Rəng dəyişikliyinə uğramış bölgələr rezeksiya edilərək çıxarılmalıdır.

Qaraciyər venalarının səhvən bağlanması və ya qatlanması qalan qaraciyərdə venoz axının pozulmasına və ödəmin inkişafına səbəb olur. Venoz staz qaraciyərin bir bölgəsində olduqda həmin bölgəni çıxarmaq lazımdır və ya əməliyyyatdan sonra diqqətlə müşahidə edilməlidir. Qalan qaraciyəri tamamilə tutan venoz axın pozulmasının aradan qaldırılması çətindir. Venaya qoyulan liqaturanın açılması vfayda vermədiyi hallarda venoz plastika, həttda transplantasiya lazım gələ bilir.

Böyük həcmli rezeksiyalardan sonra qalan qaraciyər damar ayaqcı̆̆ ətrafında çevrilərək damar və axacaqların burulmasına, qatlanmasına səbəb ola bilir. Bağların kəsilməsi də buna şərait yaradır. Ona görə də əməliyyatın sonunda qalan qraciyərin hərəkətliliyinə diqqət edilməlidir. Yerdəyişmə ehtimalı yüksək olan hallarda qalan qaraciyər bir neçə tikişlə diafraqmaya tikilir.

Oməliyyat sahəsinə yaxın orqanlar, xüsusən 12 barmaq bağırsaq, mə'də, köndələn bağırsaq, aşağı boş vena diqqətlə yoxalnmalıdır. Zədələnmə olars bərpa edilməlidir. 
Belalikla, bu marhaladə qalan qraciyardə qanaxma, öd sızıntısı, nekroz, venoz axın pozulmasl, yerdəyişmə, atraf orqanlarda zədəlanmə olubolmadiğ yoxlanılır va uyğun tədbirlorla aradan qaldirllır. Rezeksiya sathinin omentoplastika, " $U$ "- " $Z$ "- şəkilli tikişlarla tikilmasi va diğar işlanma üsulların istifadə va tövsiyə etmirik.

\section{VIII mərhələ: Drenaj və yaranın tikilməsi}

Đməliyyatın bu son mərhələsində qarın boşluğu drenaj edilir və laparatomi yarası tikilir. Drenaj diafraqmaaltı, qaraciyəraltı nahiyyələrdə maye toplamnasının qarşısını almaq və rezeksiya səthindən baş verən qanaxmaların, öd sızmasının erkən diqnozu üçün vacibdir. Drenaj rezeksiya səthinə yaxın bölgəyə, diafraqmaaltı və ya qaraciyəraltı nahiyyəni əhatə edəcək şəkildə yerləşdirilir və əsas yaradan kənardan çixarılır.

Laparotomi yarası qat-qat tikilir. Đzələ və aponevroz qatlarının birlikdə sorulmayan sintetik monoflament saplarla tikilməsi tövsiyə olunur.

\section{QARACIYӘR REZEKSIYASI ӘMӘLIYYATININ QISA XÜLASӘSI}

\section{Rezeksiyaya göstoriş}

- Hepatosellular karsinoma və diğər birincili bəd xassəli şişlər: I, II, bə’zən də III dövrdə

- Metastatik şilşlər: ekstrahepatik yayılım olmadıqda

- Hepatik adenoma

- Fokal nodular hiperplaziya

- Hemangioma, şimptomatik, 5 sm-dən böyük

- Periferik kistlor

- Neoplastik kistlər

- İntrahepatik daşlar

- Canlıdan qaraciyər köçürülməsi

- IV derəcəli qaraciyər travması (destruksiya, devaskularizasiya)

\section{Rezeksiyaya əks göstərişlar}

- III, IV dövrdə hepatosellular karsinoma və diğər birincili bəd xassəli şişlər

- Ekstrahepatik yayılımı olan metastatik şişlər

- Kəskin hepatit

- Dekmpensasiya dövründəki sirroz 
- Oməliyyatdaxili indosianin sınağı 3-dən kiçik olanlar

- Qan dövranı, ağciyər, böyrək yetməzliyi, şok, koma

I morhələ: Qarın boşluğunun açılması- kəsiklər

- Sağ paydakı və hər iki paydakı rezeksiyalarda: ikitərəfli qabırğaaltı,

"Mersedes", Topçubaşov, Mak Dermotti, kasiklari

- Sol paydak1 rezeksiyalarda: orta yuxarı, Feodorov kasiklari

\section{II marhola: Omaliyyatdaxili diaqnnostika}

- Әməliyyatönü müayina nəticalari, amiyyatdaxili müayinalarəbaxma, palpasiya, punksiya, biopsiya USM, ӘDISY sınă̆ına dayanaraq aşağıdakı mosalalar hall edilir

- Xəstəlik rezektabeldirmi? - xastaliyin tabiati va yayılma daracəsi nazara alınır.

- Qaraciyər rezektabeldirmi? - rezeksiya həcmi və qaraciyərin funksional ehtiyatları nozวra alınır.

\section{III marhala: Sarbastlaşdirma}

- Çıxarılacaq bölgə ətraf toxumalarla bitişmələrdən ayrılır

- Çıxarılacaq bölgənin bağları (girdə, oraqvari, tac, üçbuvcaq bağlar) kəsilir

\section{IV marhəla: Mağistral damarlara nozarat}

- Qaraciyər- 12 barmaq bağırsaq asqıya alınır

- Oməliyyat vaxtı lazım gəldikdə (profuz qanaxmalar, sirrotik qaraciyər rezeksiyalarında) 10 dəq. sıxma, 5 dəq. açma işləmi yerinə yetirilir. Sıxma-açama 5-6 dəfə təkrar oluna bilər.

V mərhələ: Damar ayaqcı̆̆ının bağlanması

- Ekstrahepatik üsul: sağ və ya sol payın qapı damar və axacaqları qaraciyər- 12 barmaq bağırsaq bağının içərisində sərbəstləşdirilib bağlanir.

- Intrahepatik üsul: Qaraciyər qapısından 2 sm yuxarıda Qlisson kapsulu 2-2,5 sm kəsilir $\rightarrow$ barmaqla qaraciyərə daxil olunur $\rightarrow$ parenxima əzilərək qapı ayaqcığı tapılır $\rightarrow$ ayaqcığa sıxıcı qoyulub doğru tapıldığ 1 yoxlanılır $\rightarrow$ ayaqcıq bağlanır

- Sol seqment ayaqciqları girdə bağ çuxurunda, sağ pay seqmentlərinin qapı ayaqcıqları öd kisəsi yatağına yaxın yerdə axtarılır. 
VI marhala: Parenximanın kasilmasi

- Çıxarılacaq bölgənin sərhəddləri dəqiqləşdirilir: törəmənin yerinə, ölçüsünə görə; anotomik bölganin təxmini sarhəddlarinə görə; qapı ayaqcı̆̆ı bağlandıqdan sınra rong dayişikliyina göra

- Venadan 1 sm distala, bəd xassəli törəmədən ən az 1 sm kənarda Qlisson kapsulu koaqulyatorla kəsilir

- Ozmə və ya ultrasəs bıçağı ilə parenxima damar-axacaq elementlerindən sərbəstləşdirilir $\rightarrow$ bağlanır $\rightarrow$ kəsilir

- Sərbəstləşdirmə $\rightarrow$ bağlama $\rightarrow$ kəsmə işləmi parenxima tam ayrılana qədər davam etdirilir.

- Qaraciyər venası parenxima içərisində bağlanır kəsilir.

\section{VII marhalə: Yaranın toftişi}

- Qalan qaraciyərdə qanaxma, öd sızması, nekroz, venoz axın, yerdayişma təftiş edilir, varsa uyğun müalicalar edilir.

- Otraf orqanlar təftiş edilir

\section{VIII marhala: Drenj va yaranın tikilmasi}

- Qalan qaraciyərin rezeksiya səthinə yaxın bölgəyə drenaj borusu qoyulur.

- Laparatomi yarası qat-qat tikilir 


\title{
QARACIYOR REZEKSIYYASINDA ӘZMӘ, ULTRASOS BIÇAĞI VӘ ARQONLU KOAQULYATORUN TəTBIQі
}

\begin{abstract}
Klinik tədqiqat 1985-1996-cı illəridə Türkiyə Yüksək İxtisas Xəstəxanası, Ankara Universiteti Cərrahi Onkoloji Bölümü və Başkənd Universiteti Ümumi Corrahiyyə kafedrasında qaraciyər rezeksiyası olunan cəmi 165 xəstənin müayinə və müalicə nəticələrini əhatə etmişdir. Xəstələrin yaşı, cinsi, xəstəliyi, qaraciyər parenximasındkı diffuz dəyişikliklər, yanaşı xəstəliklər və rezeksiya həcmi haqqında ümumi mə’lumat Cədval 6.1-də verilmişdir. Rezeksiya olunan xəstələrin əksəriyyətini orta yaşlilar və kişilər (78,8\%) təşkil etmiş, kişilər qadınlardan 3,7 dəfə çox oluşdur. Xəstələrin böyük hissəsində hepatit virusu səthi antigeni müsbət olmuş (HBsAg+) və 47 nəfərdə xronik hepatit, digərləri isə virus daşıyıcısı olmuşdur.

Rezeksiyaya göstərişlərə gəldikdə isə, xəstələrin əksəriyyətində rezeksiya qaraciyərin birincili şişləri $(64,2 \%)$, metastatik şişlərinə görə $(16,4 \%)$ və canlıdan qaraciyər köçürülməsi üçün donorlarda $(12,7 \%)$ aparılmışdır. Qaraciyərin birincili şişləri metastatik şişlərdən 3,9 dəfə çox olmuşdur və bunun səbəbi xəstələrdə qaraciyər sirrozunun yüksək olmasıdır. Sirroz fonunda mə'lum olduğu kimi, hepatosellular karsinoma çox rast gəldiyi halda, metastatik şişlər nadirdir və bizim xəstələrdə müşahidə edilməmişdir. Birincili şişlər içərisində hepatosellular karsinoma əksəriyyət təşkil etmişdir (87/106- 82,1\%).

Yanaş1 xəstəliklər 24 xəstədə $(14,5 \%)$ rast gəlmişdir. Bu xəstəliklər içərisində ən çox rast gələni ürək-damar xəstəlikləri, şəkərli diabet və xolesistitdir.
\end{abstract}

Cadval 6.1 
Xəstələr haqqında ümumi mə'lumatlar və onların rezeksiya və müalicə üsuluna görə paylanması.

\begin{tabular}{|c|c|c|c|c|c|}
\hline \multirow[t]{2}{*}{ Göstəricilər } & \multicolumn{2}{|c|}{$\begin{array}{l}\text { Xəstələrin } \\
\text { ümumi say1 }\end{array}$} & \multicolumn{3}{|c|}{ Rezeksiya üsulu } \\
\hline & müt. & $\%$ & Әzmə & UB & UBAK \\
\hline Yaş & $55,4 \pm 4$ & & $52,4 \pm 4$ & $55,4 \pm 4$ & $57,4 \pm 4$ \\
\hline Kişi & 130 & 78,8 & 37 & 51 & 42 \\
\hline Qadın & 35 & 21,2 & 9 & 15 & 11 \\
\hline HBsAg müsbət & 113 & 68,5 & 31 & 42 & 40 \\
\hline Yanaşı xəstəliklər & 24 & 14,5 & 5 & 10 & 9 \\
\hline \multicolumn{6}{|l|}{ Rezeksiyaya göstərişlər } \\
\hline Qaraciyər donoru & 21 & 12,7 & - & 12 & 9 \\
\hline Metastatik şiş & 27 & 16,4 & 9 & 11 & 7 \\
\hline $\begin{array}{l}\text { Hepatosellular } \\
\text { karsinoma }\end{array}$ & 87 & 52,7 & 20 & 35 & 32 \\
\hline Hemangioma & 17 & 10,3 & 10 & 4 & 3 \\
\hline Hepatik adenoma & 2 & 1,2 & 1 & - & 1 \\
\hline Endokrin şiş & 2 & 1,2 & 1 & - & 1 \\
\hline Exinokokk & 4 & 1,8 & 2 & 1 & 1 \\
\hline Alveolokokkoz & 1 & 0,6 & - & - & 1 \\
\hline İntrahepatik xolelitiaz & 2 & 1,2 & 1 & - & 1 \\
\hline Karoli xəstəliyi & 2 & 1,2 & 1 & 1 & - \\
\hline \multicolumn{6}{|l|}{ Qaraciyərin vəziyyəti } \\
\hline Sirroz & 59 & 35,8 & 14 & 24 & 21 \\
\hline Xronik hepatit & 54 & 32,7 & 15 & 19 & 20 \\
\hline Normal qaraciyər & 52 & 31,5 & 16 & 21 & 15 \\
\hline \multicolumn{6}{|l|}{ Rezeksiya həcmi } \\
\hline Böyük həcmli & 64 & 38,8 & 16 & 25 & 23 \\
\hline Orta həcmli & 64 & 38,8 & 16 & 26 & 22 \\
\hline Kiçik həcmli & 37 & 22,4 & 13 & 13 & 11 \\
\hline Cәm & 165 & & 45 & 64 & 56 \\
\hline
\end{tabular}

Tədqiqatın məqsədinə uyğun olaraq rezeksiya əməliyyatında parenximanı kəsmə üsuluna görə xəstələr qruplara ayrılmışdır. 
ayrilmışdır:

Qaraciyər parenximasının vəziyyətinə görə xəstələr 3 qrupa

- qaraciyəri normal olan xəstələr - 52 xəstə. Bu xəstələrdə qaraciyərdə diffuz dəyişiklik olmamışdır, qaraciyər funksiyalarındakı dəyişikliklər başlıca olaraq əsas xəstəliklə əlaqədar olmuşdur. Qaraciyər donorlarında qaraciyər morfo-funksiyonal cəhətdən praktik sağlam olmuşdur.

- $\quad$ xronik hepatit olan xəstələr - 54 xəstə. Bu xəstələrdə qaraciyərdə xronik aktiv və persistan hepatit və buna uyğun funksiyonal dəyişikliklər qeyd edilmişdir

- qaraciyər sirrozu olan xəstələr - 59 xəstə. Bu xəstələrin qaraciyərində əsas xəstəliklə yanaşı sirrotik dəyişikliklər və funksiyonal pozulmalar mövcud olmuşdur.

Sirroz va xronik hepatit zamani qaraciyərdo fibrotik prosesin mövcud olduğunu va parenximanı kasarkan fibrotik elementlarin kasma prosesinə tə’sirini nəzərə alaraq rezeksiya üsullarının müqayisəsindo sirrotik və xronik hepatiti olan xəstələr ümumi ad altında, (fibrotik qaraciyər) adı altında nazardan keçirilmişdir.

Qaraciyər rezeksiyasında parenximanı kəsmə üsulllarının yararlılığını tə'yin etmək məqsədinə uyğun olaraq xəstələr 3 qrupa ayrılmışdır (Codval 6.2):

- $\quad$ Ozmə qrupu - 45 xəstə. Bu qrupda parenximanı kəsmək üçün barmaqla (digitoklaziya) və ya alətlə əzmə texnikası istifadə edilmişdir.

- Ultrasəs bıçağı (UB) qrupu - 64 xəstə. Bu qrupda parenximi kəsmək üçün ultrasəs bıçağı tətbiq edilmişdir.

- Ultrasəs biçağı və arqonlu koaqulyator (UBAK) qrupu - 56 xəstə. Bu xəstələrdə parenximanı kəsərkən ultrasəs bıçağı ilə parenximadan ayrılıb sərbəstləşdirilən kiçik intrahepatik damarlar arqonlu koaqulyatorla dağlanmış və kəsilmişdir. 
Qaraciyər rezeksiyasında əzmə üsulu, ultrasəs bıçağı vo arqonlu koaqulyator

Cadval 6.2

Xəstวlərin rezeksiya üsulu, rezeksiya həcmi və qaraciyər dəyişiklikinlarə göra paylanması

\begin{tabular}{|r|c|c|c|c|}
\hline $\begin{array}{l}\text { Qaraciyərin } \\
\text { vəziyyəti və } \\
\text { rezeksiya } \\
\text { həcmi }\end{array}$ & Өzmə & UB & UBAK & \multirow{2}{*}{ Toplam } \\
\cline { 2 - 4 } Normal & & & & \\
Böyük & 16 & 21 & 15 & 52 \\
Orta & 6 & 11 & 7 & 25 \\
Kiçik & 3 & 7 & 5 & 18 \\
Fibrotik & 29 & 3 & 3 & 9 \\
Böyük & 9 & 43 & 41 & 113 \\
Orta & 10 & 14 & 16 & 39 \\
Kiçik & 10 & 10 & 17 & 46 \\
\hline Cəmi & 45 & 64 & 56 & 28 \\
\hline
\end{tabular}

Tətbiq olunan bu 3 rezeksiya üsulu aşağıdakı göstəricilərə görə müqayisə edilmişdir:

* intraoperativ qanaxma

* köçürülon qanın miqdarı

* rezeksiyaya sorf olunan zaman

* qapt elementlorinin stxulma müddoti

* qaraciyordo baş veron nekroz.

* omoliyyatdan sonrakı ă̆ırlaşmalar

Qanaxma miqdarı qaraciyər parenximasını kəsərkən baş verən qanaxmanın miqdarını ifadə edir. Qanaxma şiddoti isə, parenximanın kəsilməsi vaxtı kəsik sahəsinin vahid sahəsindən axan qanın miqdarını 
göstərir. Bu göstəricini hesablamaq üçün qanaxma miqdarı və rezeksiya səthinin sahəsi tapılmışdır və aşağıdakı düsturdan istifadə edilmişdir.

Qanaxma şiddəti $=\frac{\text { qanaxma miqdarý }(\mathrm{ml})}{\text { rezeksiya suthinin sahusi }(\mathrm{sm} 2)}$

Rezeksiya müddəti qaraciyər parenximasının kəsilməsinə sərf edilən zamanı ifadə edir. Bu müddət qaraciyərin damarlarının sərbəstləşməsindən başlayır, rezeksiya bitdikdən sonra tam hemostaza qədər olan zamanı əhatə edir. Parenximanı kəsmə sür'əti vahid zamanda kəsilən parenxima sahəsini ifadə edir və aşağıdakı düsturla hesablanır.

Parenximanı kəsmə sür 'oti $=\frac{\text { rezeksiya suthinin sahusi }(\mathrm{sm} 2)}{\text { rezeksiya müdduti }(\mathrm{dnq})}$

Transfuziya miqdarı və portal sıxac müddətinin rezeksiya səthinə olan nisbətləri də, anoloji qayda ilə ölçülmüşdür.

Qanaxma şiddəti, parenximanın kəsmə sür'əti, transfuziya miqdarı və portal s1xac müddətinin rezeksiya səthi sahəsinə nisbəti kimi göstəricilərin istifadə etməklə rezeksiya həcmi və sahəsinin qanaxma miqdarı və rezeksiya müddətinə tə'siri aradan qaldırılmışdır. $\mathrm{Bu}$ isə, rezeksiya üsullarının müqayisəsini daha obyektiv zəmində aparmağa imkan verir.

Qaraciyər nekrozunu qiymətləndirmək üçün laborator (ALT, AST) və patohistoloji göstəriçilər istifadə olunmuşdur.

Qaraciyərin dəyişiklikləri, rezeksiya həcmi və əməliyyatönü dövrdə laxtalanma sisteminin dəyişiklikləri rezeksiya üsulunun effektivliklərini tə’yin etmək üçün seçdiyimiz göstəricilərə ciddi tə’sir göstərir. Bunu nəzərə alaraq üsullar arasında müqayisə aşağıdakı qaydada aparılmışdır:

1. Qaraciyərdo struktur doyişikliklari nəzərə alınmışdır. Rezeksiya üsullarının noticalori normal vo fibrotik qaraciyarlardo ayrilıqda müqayisa edilmişdir.

2. Rezeksiya hacminin naticalaro to'sirini aradan qaldırmaq, müqayisəni asanlaşdırmaq vo daha obyektiv zəmindo aparmaq maqsadi ilo üsulların müqayisəsində qanaxma miqdarı və rezeksiya müddəti nəzərə alınmamış, 
daha obyektiv göstoricilor olan qanaxma şiddəti va parenximi kasmə sür'ati istifado edilmişdir.

3. Qaraciyardə töradilan nekrozun biokimyəvi və patohistoloji göstəricilari böyük vo orta hacmli rezeksiyalarda daha bariz olduğu va həcmlar arasında ciddi forqlar olmadığını nəzərə alaraq, qaraciyər nekrozu üzra aparılan müqayisədə böyük va orta hacmli rezeksiyaların nəticələrindən istifado edilmişdir.

4. Әməliyyatönü dövrda normokoaqulyasiyası olan xastalarin rezeksiya naticalarinin normal quruluşlu qaraciyari olan xastalarin naticalarindan, hipokoaqulyasiyall xastalarin naticalarinin is fibrotik qaraciyarlari olan xastalarin naticalarindan ciddi farqlanmadiyi har 3 üsulda müşahido edildiyi üçün koaqulyasiya dayişikliklari müqayisadə nazərə alınmamışdır.

\section{NORMAL QARACIYORLӘRDӘ REZEKSIYA ÜSULLARININ QARŞILIQLI MÜQAYISəSI}

\section{Qanaxma}

Normal qaraciyərdə yerinə yetirilən rezeksiyalarda qanaxma miqdarı Cədvəl 6.3-də verilmişdir. UB və UBAK üsullarında qanaxma miqdarı daha azdır.

Qanaxma şiddəti əzmə üsulunda $30,5 \pm 2,1 \mathrm{ml} / \mathrm{sm}^{2}$, ultrasəs biçağ 1 üsulunda $17,5 \pm 1,4 \mathrm{ml} / \mathrm{sm}^{2}$, UBAK üsulunda isə $14,3 \pm 1,5 \mathrm{ml} / \mathrm{sm}^{2}$ olmuşdur (Qrafik 6. 1). qanaxma şiddətin ən çox əzmə, ən az isə UBAK üsulunda müşahidə edilmişdir.

Codval 6.3

Normal qaracəyərdə əzmə, UB və UBAK üsulu ilə rezeksiyalarda rezeksiya hacmindən astl olaraq qanaxma miqdart.

\begin{tabular}{|l|c|c|c|}
\hline \multirow{2}{*}{ Rezeksiya üsulu } & \multicolumn{3}{|c|}{ Qanaxma miqdarı (ml) } \\
\cline { 2 - 4 } & $\begin{array}{c}\text { Böyük } \\
\text { həcmli } \\
\text { rezeksiya }\end{array}$ & $\begin{array}{c}\text { Orta } \\
\text { həcmli } \\
\text { rezeksiya }\end{array}$ & $\begin{array}{c}\text { Kiçik } \\
\text { həcmli rezeksiya }\end{array}$ \\
\hline
\end{tabular}


Nuru Yusifoğlu Bayramov. Qaraciyər rezeksiyast

\begin{tabular}{|c|c|c|c|}
\hline Әzmə & $1412 \pm 41$ & $1045 \pm 36$ & $535 \pm 21$ \\
\hline UB & $1090 \pm 34$ & $849 \pm 29$ & $275 \pm 21$ \\
\hline UBAK & $825 \pm 43$ & $678 \pm 37$ & $196 \pm 27$ \\
\hline
\end{tabular}

Ancaq, statistik analizdə fərqli nəticələr ortaya çıxmaqdadır. Әzmə üsulu ilə müqayisədə həm ultrasəs bıçağı, həm də UBAK usulu qanaxma şiddətini əhəmiyyətli dərəcədə (hər 2 halda $p<0,05$ ) və uyğun olaraq 1,8 və 2 dəfə azaldır. Ultrasəs bıçağı ilə UBAK müqayisə edildikdə isə qanaxma şiddəti UBAK üsulunda nisbətən az olmasına baxmayaraq, fərqin statistik əhəmiyyətli $(p>0,05)$ olmadığı meydana çıxır. Yə'ni ultrasəs bıçağı ilə yerinə yetirilən rezeksiyalarda arqonlu koaqulyatorun əlavə edilməsi qanaxma şiddətini ciddi olaraq dəyişdirmir.

Beləliklə, aparılan müqayisəli analiz göstərir ki, normal parenximaya malik olan qaraciyərlərin rezeksiyalarında qanaxmanı azaltmaq üçün ən effektiv üsul ultrasəs bıçağı və UBAK üsuludur və bu 2 metodlar birbirinə yaxın yararlılığa malikdir.

\section{Transfuziya miqdart}

Normal qaraciyərlərdə aparılan rezeksiyalarda rezeksiya sahəsinə düşən transfuziya miqdarının əməliyyat üsuluna görə müqayisəli analizi göstərir ki, həm $\operatorname{UBAK}\left(8,1 \pm 0,8 \mathrm{ml} / \mathrm{sm}^{2}\right)$ həm də ultrasəs bıçağ $\left(10,2 \pm 0,9 \mathrm{ml} / \mathrm{sm}^{2}\right)$ əzmə üsuluna $\left(17,9 \pm 1,0 \mathrm{ml} / \mathrm{sm}^{2}\right)$ nəzərən transfuziya miqdarını əhəmiyyətli dərəcədə və uyğun olaraq 1,8 və 2 dəfəyə yaxın azaltmışdır(Qrafik 6. 2). UBAK ilə ultrasəs bıçağı arasındakı fərqlər isə statistik əhəmiyyətli olmamışdır 
Normal qaraciywr

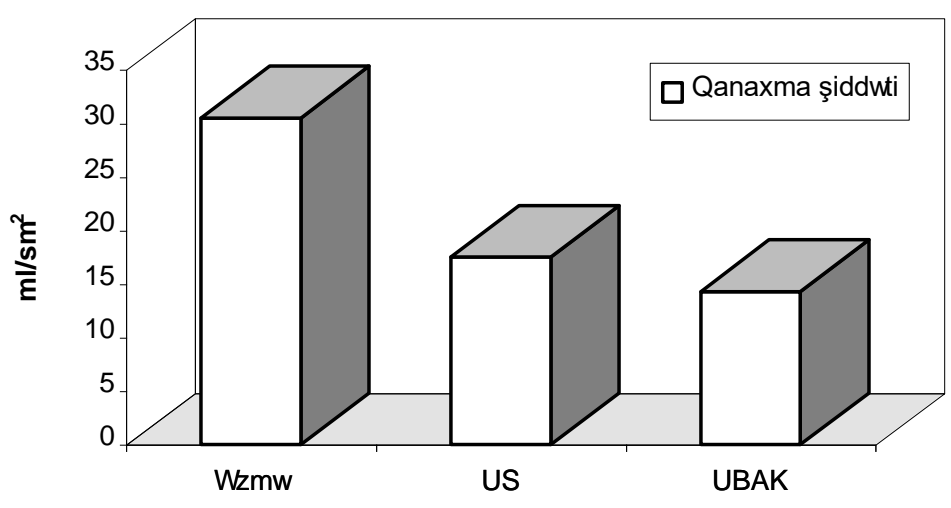

Qrafik 6. 1. Normal qaraciyərlordə rezksiya üsulundan asılı olaraq qanaxma şiddati

Normal qaraciywr

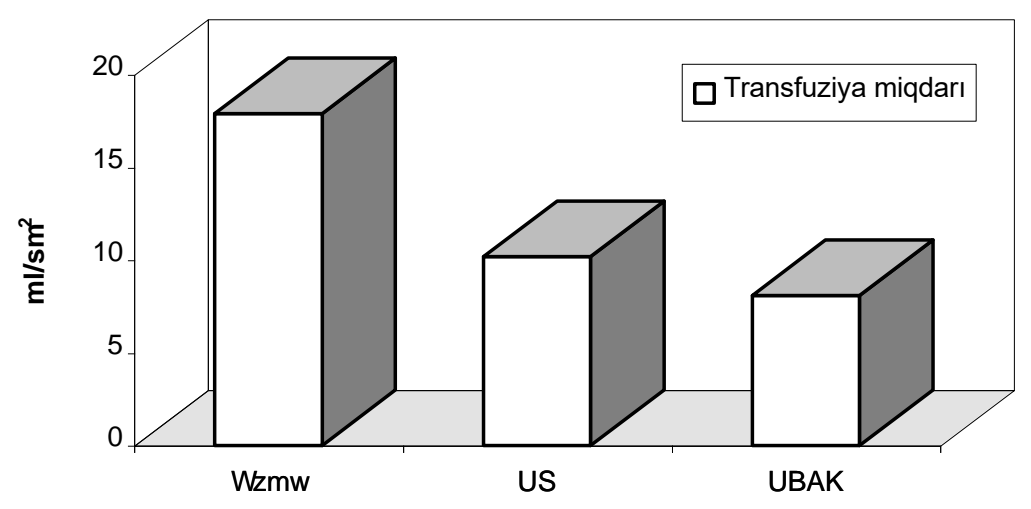

Qrafik 6. 2. Normal qaraciyərlordə rezksiya üsulundan asılı olaraq transfuziya miqdarl 
Belalikla, normal quruluşlu qaraciyərin rezeksiyalarında UBAK vo ultrasas bıçă̆ı üsulları rezeksiya sathinə düşən transfuziya miqdarına görə bir birindən ahəmiyyatli daracəda farqlanmir va azma üsuluna nəzərən transfuziya miqdarını taxminan 2 dəfa azaldır.

\section{Rezeksiya müddoti}

Normal qaraciyərdə yerinə yetirilən rezeksiyalarda rezeksiya müddəti Cadval 6.4-do verilmişdir. UB və UBAK üsullarında rezeksiya müddəti daha azdır.

Normal qaraciyərlərdə parenximanı kəsmə sür'əti əzmə üsulunda $0,42 \pm 0,02 \mathrm{sm}^{2} / \mathrm{d} ə q$, ultrasəs bıçağı ilə rezeksiyalarda $0,98 \pm 0,07 \mathrm{sm}^{2} / \mathrm{d} ə$, UBAK üsulunda isə $1,12 \pm 0,08 \mathrm{sm}^{2} /$ dəq təşkil etmişdir. Göründüyü kimi UBAK üsulu ən yuksək kəsmə sür'ətinə malik metoddur (Qrafik 6.3). Statistik analizdə ultrasəs bıçağının əzmə üsuluna nisbətən əhəmiyyətli dərəcədə $(\mathrm{p}<0,05)$ və 2,3 dəfə sürətli kəsmə üsulu olduğu üzə çıxır.

Cadval 6.4

Normal qaracəyərda azmə, UB və UBAK üsulu ila rezeksiyalarda rezeksiya hacmindan asilı olaraq amaliyyat müddəti

\begin{tabular}{|l|c|c|c|}
\hline \multirow{2}{*}{ Rezeksiya üsulu } & \multicolumn{3}{|c|}{ Parenximanın kəsmə müddəti (dəq.) } \\
\cline { 2 - 4 } & $\begin{array}{c}\text { Böyük } \\
\text { həcmli } \\
\text { rezeksiya }\end{array}$ & $\begin{array}{c}\text { Orta } \\
\text { həcmli } \\
\text { rezeksiya }\end{array}$ & $\begin{array}{c}\text { Kiçik } \\
\text { həcmli rezeksiya }\end{array}$ \\
\hline Ozmə & $142 \pm 8$ & $112 \pm 8$ & $54 \pm 4$ \\
UB & $72 \pm 9$ & $59 \pm 4$ & $25 \pm 3$ \\
UBAK & $70 \pm 5$ & $58 \pm 5$ & $22 \pm 4$ \\
\hline
\end{tabular}

UBAK üsulu əzmə üsulundan əhəmiyyətli dərəcədə fərqlənməklə yanaşı ( $p<0,05), 2,6$ dəfə sürətli kəsmə imkanına malikdir. UBAK üsulu ultrasəs bıçağına nisbətən yüksək kəsmə sür'ətinə malik olsa da onlar arasındakı fərq statistik əhəmiyyətli olmamışdır $(\mathrm{p}>0,05)$. 


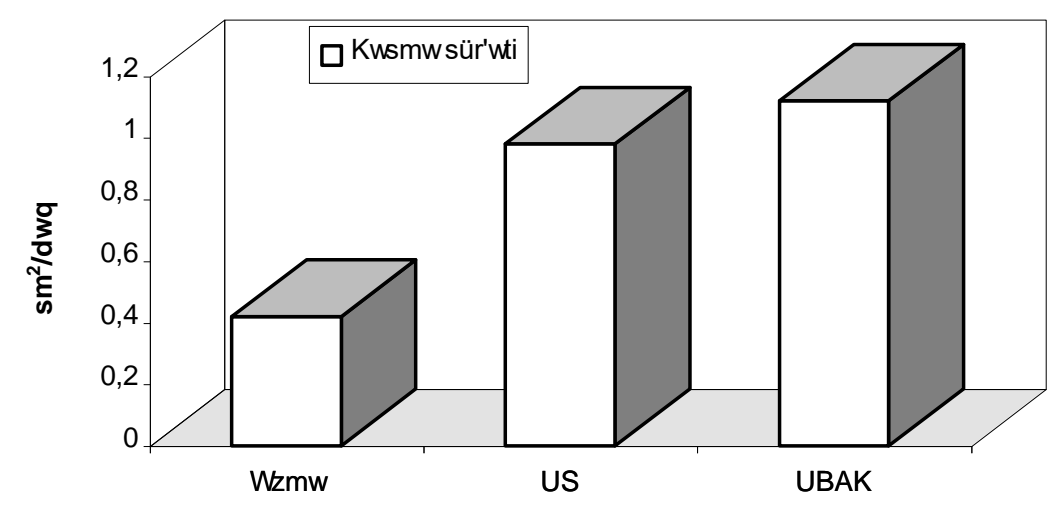

Qrafik 6. 3. Normal qaraciyərlərdə rezksiya üsulundan asılı olaraq parenximanı kasma sür'ati

Beləliklə, normal qaraciyərlərin rezeksiyalarında parenximanı kəsmə sür’ətinə görə UBAK və ultrasəs bıçağı üsulları bir - birinə yaxındır və əzmə üsuluna nəzərən kəsmə sür'ətini 2,5 dəfə artırır.

\section{Portal sixac müddoti}

Normal qaraciyərlərin əzmə üsulu ilə rezeksiyalarında rezeksiya səthinə düşən portal sıxac müddəti $0,32 \pm 0,02 \mathrm{dəq} / \mathrm{sm}^{2}$, ultrasəs biçağı ilə rezeksiyalarında $0,18 \pm 0,01 \mathrm{dəq} / \mathrm{sm}^{2}$, UBAK üsulu ilə rezeksiyalarında isə $0,16 \pm 0,01 \mathrm{dəq} / \mathrm{sm}^{2}$ olmuşdur (Qrafik 6.4). Bu nəticələr göstərir ki, normal quruluşlu qaraciyərlərin rezeksiyalarında əzmə üsulu ilə müqayisədə ultrasəs bıçağı və UBAK üsulu portal elementlərin müvəqqəti sıxma müddətini əhəmiyyətli dərəcədə və təxminən 2 dəfə azaltmışdır. UBAK üsulu ilə ultrasəs bıçağı arasındakı fərqlər isə statistik əhəmiyyətli olmamışdır. Bundan başqa portal sıxaca əzmə üsulunda $75 \%$ halda, ultrasəs biçağ üsulunda $66,7 \%$ halda, UBAK üsulunda isə $46,7 \%$ halda zərurət yaranmışdır.

Belaliklo, normal qaraciyorin rezeksiyalarında portal sixac müddoti ultrasos bıçağı vo UBAK üsulları bir-birindon ciddi forqlonmir vo ozmo üsuluna nozoron daha yararlıdir. 


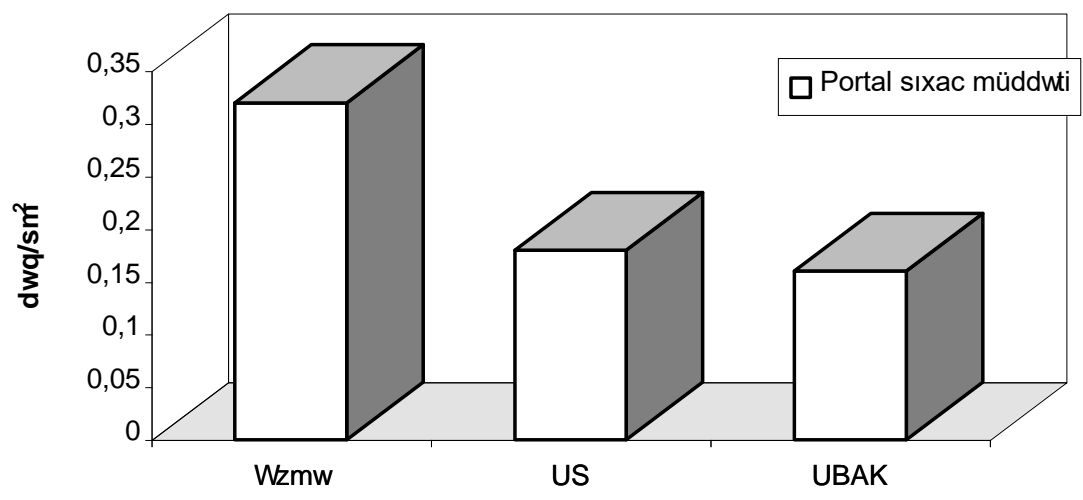

Qrafik 6. 4. Normal qaraciyərlordə rezksiya üsulundan asılı olaraq portal sixac müddati

\section{Qaraciyor nekrozu}

Normal qaraciyərlərdə aparılan rezeksiyalarda ALT səviyyəsinin araşdırılması göstərir ki, rezeksiya üsulundan asılı olmayaraq fermentin qandakı aktivlik səviyyəsi ümumi qanunauyğunluqlarla dəyişir. Hər 3 üsulla aparılan rezeksiyalardan sonra birinci gündə ALT səviyyəsi maksimal artır, 3-cü gündə maksimal səviyyədən əhəmiyyətli dərəcədə düşür, 5-ci gündə azalma davam edir və 7-ci gündə normal səviyyəyə qayıdır (Qrafik 6. 5).

Rezeksiya üsulları fermentin artma miqdarı üzrə müqayisə edildikdə UBAK üsulunda ALT-1n maksimal artma miqdarı (339 \pm 15 TV/L) ultrasəs bıçağı $(312 \pm 16 \mathrm{TV} / \mathrm{L})$ və əzmə üsulundakına $(282 \pm 16 \mathrm{TV} / \mathrm{L})$ nəzərən yüksək görünsə də, onlar aralarındakı fərqlər statistik əhəmiyyətli olmamışdır (bütün hallarda $\mathrm{p}>0,05$ ). 


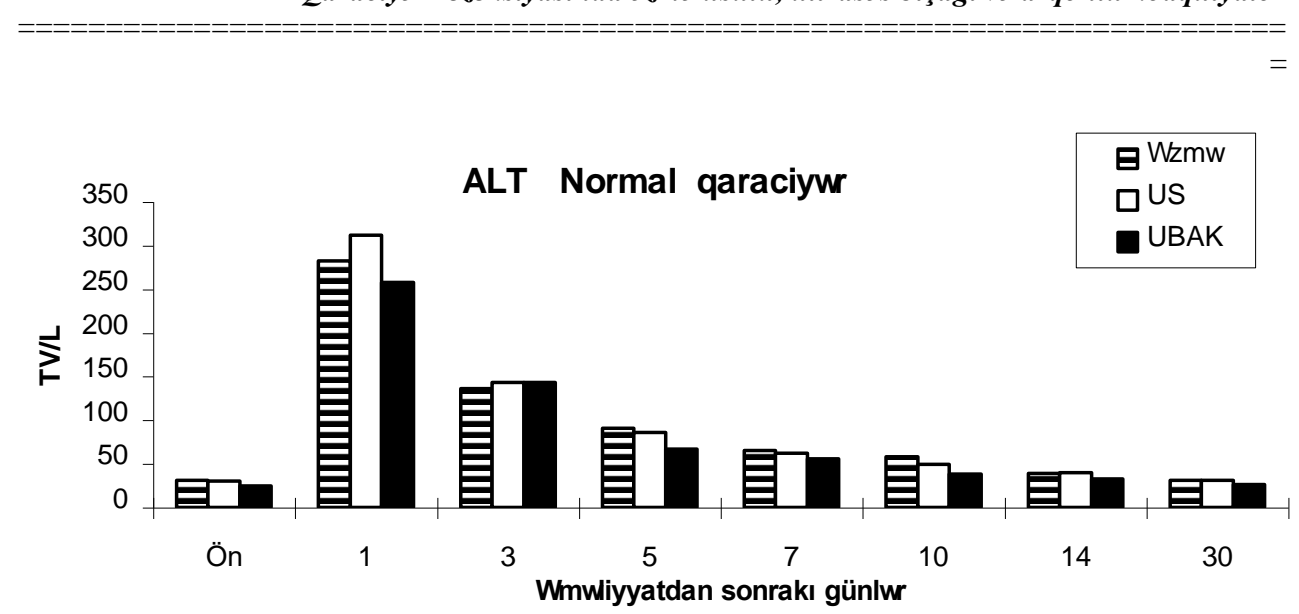

Qragik 6. 5. Normal qaraciyərdə rezeksiya üsulundan sılı olaraq ALT dinamikast

$\mathrm{Bu}$ vəziyyətə yaxın hal AST dinamikasının müqayisəsində də meydana çıxmışdır. Rezeksiya üsulundan asılı olmayaraq əməliyyatdan sonra 1-ci gündə AST-nin plazmadakı aktivlik səviyyəsi maksimal artmış, 3-cü gündə maksimal səviyyədən əhəmiyyətli düşmə baş vermiş, 5-ci gündə isə normal hüdudlara enmişdir (Qrafik 6. 6). ALT səviyyəsində olduğu kimi, AST-nin maksimal artma səviyyəsi UBAK üsulunda (264 $\pm 15 \mathrm{TV} / \mathrm{L})$ ultrasəs bıçağı $(237 \pm 16 \mathrm{TV} / \mathrm{L})$ və əzmə üsuluna $(212 \pm 15 \mathrm{TV} / \mathrm{L})$ nəzərən yüksək görünsə də, onlar aralarındakı fərqlər statistik əhəmiyyətli olmamışdır (bütün hallarda $\mathrm{p}>0,05)$.

Beləliklə qaraciyər nekrozunun biokimyəvi göstəricilərinin analizidən mə'lum olur ki, rezeksiya üsulları transaminazaların dinamikası və artma səviyyələri üzrə bir-birindən əhəmiyyətli dərəcədə fərqlənmir. $\mathrm{Bu}$ onu göstərir ki, rezeksiyadan sonra ALT və AST dinamikası rezeksiya üsulundan asılı olmayaraq ümümi dinamika üzrə gedir, əzmə üsulu ilə müqayisədə ultrasəs bıçağı və UBAK üsulu qaraciyər nekrozunu ciddi surətdə artırmır.

Patohistoloji göstaricilar

Patohistoloji tədqiqatın nəticələrinin müqayisəsində nekrozun dərinliyi ultrasəs bıçağ $(9,2 \pm 1,1 \mathrm{~mm})$ ilə yerinə yetirilən rezeksiyalarda xeyli 
aşağıdadır. Ancaq bu üsulla əzmə üsulu $(14,5 \pm 2,1 \mathrm{~mm})$ və UBAK $(16,3 \pm 2,3$ $\mathrm{mm}$ ) arasında statistik əhəmiyyətli fərqlər ortaya çıxmamışdır (bütün hallarda $\mathrm{p}>0,05)$.

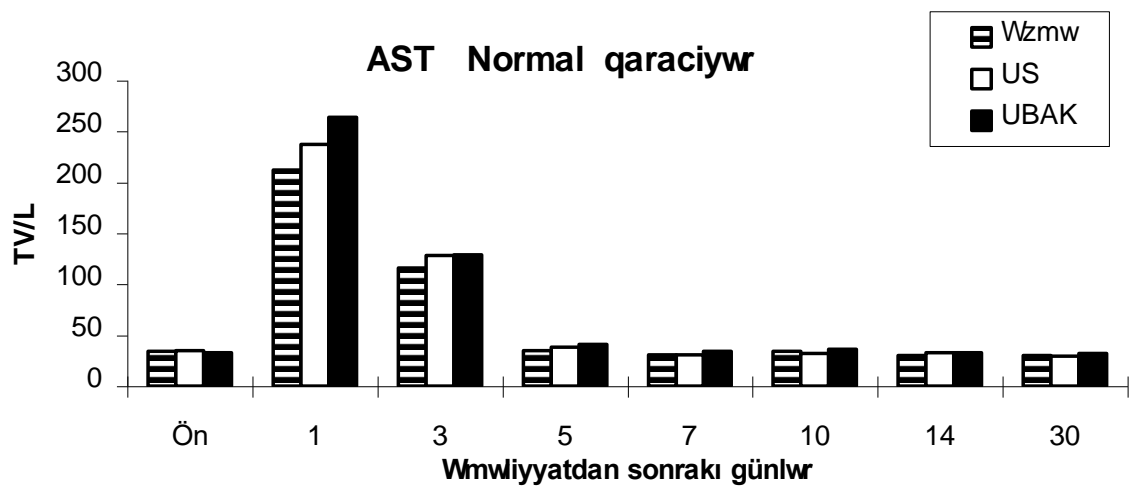

Qragik 6. 6. Normal qaraciyərdə rezeksiya üsulundan asılı olaraq AST dinamikasl

Beləliklə, həm biokimyəvi həm də patohistoloji meyarlar subut edir ki, əzmə üsulu ilə müqayisədə ultrasəs biçağı və UBAK üsulu normal qaraciyərlərdə rezeksiya vaxtı törədilən nekrozun səviyyəsini ciddi artırmır.

Ă̆ırlaşmalar

Normal qaraciyəri olan xəstələrdə rezekiyadan sonra ağırlaşmalar cəmi 9 (17,3\%) xəstədə rast gəlmişdir (Cədval 6. 5). Ozmə üsulu ilə yerinə yetirilən rezeksiyalarda ağırlaşma $4(25 \%)$, ustrasəs bıçağında $3(14,2 \%)$, UBAK ilə aparılan rezeksiyalarda isə 2 xəstədə $(13,3 \%)$ təsadüf etmişdir. Yə’ni normal qaraciyərdə ultrasəs bıçağı və UBAK üsulu rezeksiyadan sonrakı ağırlaşmaları azaldır.

Cadval 6. 5

Normal qaraciyərdo aparlan rezeksiyalardan sonra baş verən ağırlaşmaların rezeksiya üsuluna görə paylanması. 
Qaraciyər rezeksiyasında əzmə üsulu, ultrasss bıçağı vo arqonlu koaqulyator

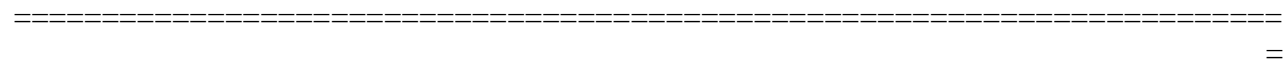

\begin{tabular}{|l|c|c|c|}
\hline Qaraciyərin vəziyyəti & $\begin{array}{c}\text { Ozmə } \\
\mathrm{n}=16\end{array}$ & $\begin{array}{c}\text { UB } \\
\mathrm{n}=21\end{array}$ & $\begin{array}{c}\text { UBAK } \\
\mathrm{n}=15\end{array}$ \\
\hline Ağırlaşma halları & $4(25 \%)$ & $3(14,2 \%)$ & $\begin{array}{c}2 \\
(13,3 \%)\end{array}$ \\
\hline
\end{tabular}

FIBBROTIK QARACIYORLӘRDə REZEKSIYA ÜSULLARININ QARŞILIQLI MÜQAYISOSI

\section{Qanaxma}

Fibrotik qaraciyərdə yerinə yetirilən rezeksiyalarda qanaxma miqdarı Codval 6.6-da verilmişdir. UB və UBAK üsullarında qanaxma miqdarı daha azdir.

Fibrotik qaraciyərlərdə rezeksiya üsullarının qanaxma şiddətinə görə müqayisəsində normal qaraciyərlərdə olduğundan fərqli nəticələr əldə edilmişdir. Fibrotik qaraciyərlərdə ultrasəs bıçağı $\left(29,4 \pm 1,5 \mathrm{ml} / \mathrm{cm}^{2}\right)$ əzmə üsuluna $(43,6 \pm 2,2$ $\left.\mathrm{ml} / \mathrm{cm}^{2}\right)$ nəzərən qanaxma şiddətini əhəmiyyətli dərəcədə $(\mathrm{p}<0,05)$ və 1,5 dəfə azaltmışdır (Qrafik 6.7). UBAK üsulunada isə qanaxma şiddəti $\left(16,4 \pm 1,8 \mathrm{ml} / \mathrm{cm}^{2}\right.$ ) həm əzmə, həm də ultrasəs bıçağına görə xeyli az olmuşdur və onlar aralarındakı fərqlər statistik əhəmiyyətlidir (hər iki halda $\mathrm{p}<0,05$ ).

Cadval 6.6

Fibrotik qaracəyərd azmə, UB və UBAK üsulu ila rezeksiyalarda rezeksiya hacmindan astl olaraq qanaxma miqdart.

\begin{tabular}{|l|c|c|c|}
\hline \multirow{2}{*}{ Rezeksiya üsulu } & \multicolumn{3}{|c|}{ Qanaxma miqdar1 (ml) } \\
\cline { 2 - 4 } & $\begin{array}{c}\text { Böyük } \\
\text { həcmli } \\
\text { rezeksiya }\end{array}$ & $\begin{array}{c}\text { Orta } \\
\text { həcmli } \\
\text { rezeksiya }\end{array}$ & $\begin{array}{c}\text { Kiçik } \\
\text { həcmli rezeksiya }\end{array}$ \\
\hline Әzmə & $1750 \pm 52$ & $1579 \pm 49$ & $745 \pm 34$ \\
UB & $1332 \pm 38$ & $1147 \pm 35$ & $412 \pm 23$ \\
UBAK & $901 \pm 41$ & $789 \pm 39$ & $231 \pm 29$ \\
\hline
\end{tabular}


Fibrotik qaraciyərlərin rezeksiyalarında UBAK üsulu qanaxma şiddətini əzmə üsuluna nisbətən 2,6 dəfə, ultrasəs bıçağına nisbətən isə 1,7 dəfə azaltmışdır.

Fibrotik qaraciywr

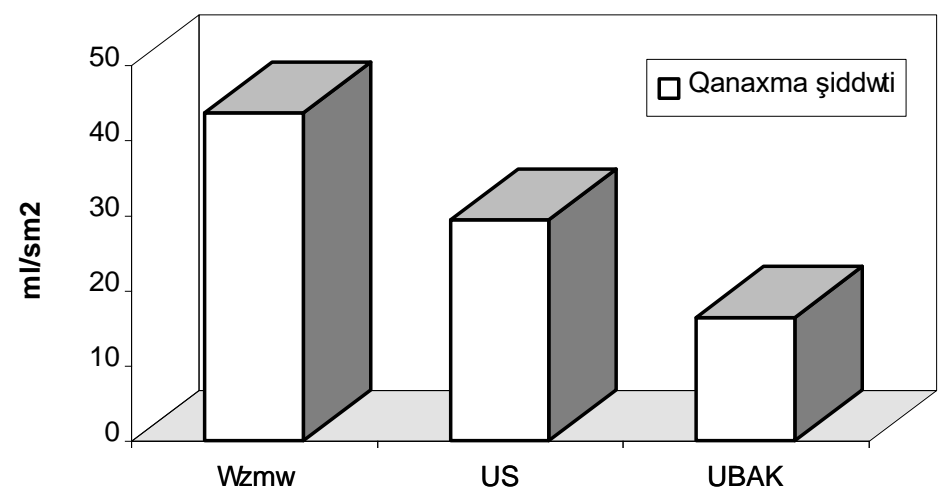

Qrafik 6. 7. Fibrotik qaraciyərlordə rezeksiya üsulundan asılı olaraq qanaxma şiddoti

Belaliklo, normal qaraciyərlordən farqli olaraq fibrotik qaraciyərlərdə aparllan rezeksiyalarda UBAK üsulu əzmə və ultrasəs bıçağ ilə müqayisadə qanaxma şiddətini əhəmiyyatli darəcədə azaltmaq üçün ən effektiv metod kimi ortaya çıxmışdır.

\section{Transfuziya miqdarı.}

Fibrotik dəyişiklikli qaraciyərlərin rezeksiyalarında rezeksiya sahəsinə düşən transfuziya miqdarına görə əməliyyat üsulları bir-birindən əhəmiyyətli dərəcədə fərqlənmişlər (bütün hallarda $\mathrm{p}<0,05$ ). Oməliyyat vaxt qan ən çox əzmə üsulunda $\left(25,8 \pm 1,1 \mathrm{ml} / \mathrm{sm}^{2}\right)$, ən az isə UBAK üsulunda $\left(9,6 \pm 0,7 \mathrm{ml} / \mathrm{sm}^{2}\right)$ köçürülmüşdür (Qrafik 6. 8). Ultrasəs biçaği ilə yerinə yetirilən rezeksiyalarda transfuziya miqdarı $\left(17,2 \pm 0,9 \mathrm{ml} / \mathrm{sm}^{2}\right)$ əzmə üsulundan 1,5 dəfə az, UBAK üsulundan isə 1,8 dəfə çox olmuşdur. 


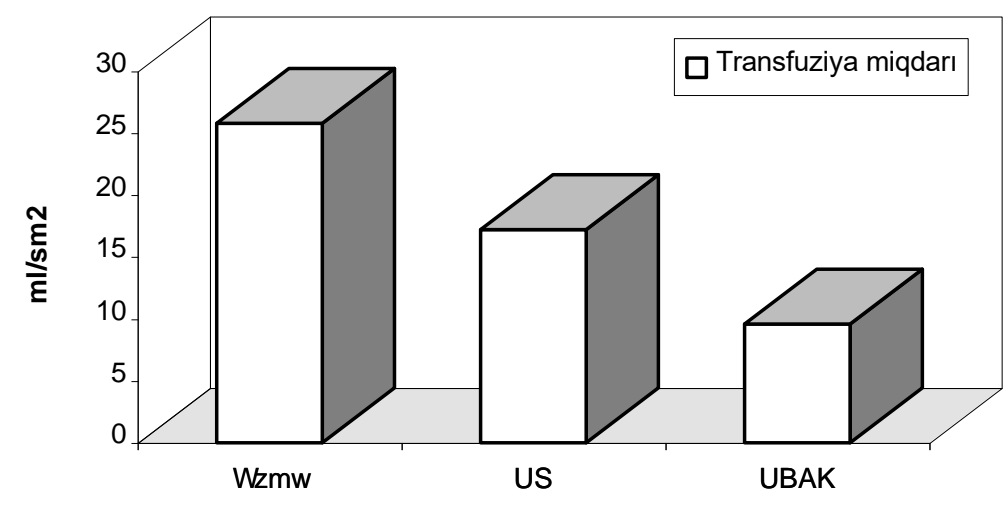

Qrafik 6. 8. Fibrotik qaraciyərlordə rezeksiya üsulundan asılı olaraq transfuziya miqdarı

Beləliklə, fibrotik dəyişiklikli qaraciyərlərin rezeksiyalarında rezeksiya sahəsi vahidinə düşən transfuziya miqdarına görə UBAK üsulu ən effektiv metoddur və bu transfuziya miqdarını ultrasəs bıçağı rezeksiyası ilə müqayisədə 1,8 dəfə, əzmə üsuluna nisbətən isə 2,7 dəfə azaltmışdır.

\section{Rezeksiya müddoti}

Normal qaraciyərdə yerinə yetirilən rezeksiyalarda rezeksiya müddəti Cadval 6.7-do verilmişdir. UB və UBAK üsullarında rezeksiya müddəti daha azdır.

Fibrotik qaraciyərlərdə aparılan rezeksiyalarda 3 üsulun kəsmə sür'ətinə görə müqayisəli analizində (Qrafik 6.9) normal qaraciyərlərdən fərqli nəticələr alınmışdır.

Cadval 6.7 
Fibrotik qaracəyərdə azmə, UB və UBAK üsulu ila rezeksiyalarda rezeksiya hacmindən asılı olaraq parenximanın kasmə müddəti (dəq.)

\begin{tabular}{|l|c|c|c|}
\hline \multirow{2}{*}{ Rezeksiya üsulu } & \multicolumn{3}{|c|}{ Parenximanın kəsmə müddəti (dəq.) } \\
\cline { 2 - 4 } & $\begin{array}{c}\text { Böyük həcmli } \\
\text { rezeksiya }\end{array}$ & $\begin{array}{c}\text { Orta } \\
\text { həcmli } \\
\text { rezeksiya }\end{array}$ & $\begin{array}{c}\text { Kiçik } \\
\text { həcmli rezeksiya }\end{array}$ \\
\hline Ozmə & $213 \pm 11$ & $183 \pm 10$ & $93 \pm 6$ \\
UB & $189 \pm 13$ & $152 \pm 11$ & $103 \pm 9$ \\
UBAK & $97 \pm 6$ & $84 \pm 6$ & $43 \pm 6$ \\
\hline
\end{tabular}

Ultrasəs bıçağının kəsmə sür’əti $\left(0,26 \pm 0,05 \quad \mathrm{sm}^{2} /\right.$ dəq $)$ əzmə üsulundan $\left(0,25 \pm 0,02 \mathrm{sm}^{2} / \mathrm{dəq}\right)$ azacıq yüksək olsa da, onlar aralarındakı fərqlər statistik əhəmiyyətli olmamışdır $(p>0,05)$. Yə’ni normal qaraciyərlərdən fərqli olaraq fibrotik qaraciyərlərdə ultrasəs bıçağ qaraciyərin kəsmə sür'ətini artırmamışdır. UBAK üsulunda kəsmə sür'əti $\left(0,71 \pm 0,07 \mathrm{sm}^{2} / \mathrm{d} ə \mathrm{q}\right)$ həm ultrasəs bıçağı, həm də əzmə üsuluna nəzərən əhəmiyyətli dərəcədə (hər iki halda $\mathrm{p}<0,05$ ) və 2,7 dəfə yüksək olmuşdur.

Fibrotik qaraciywr

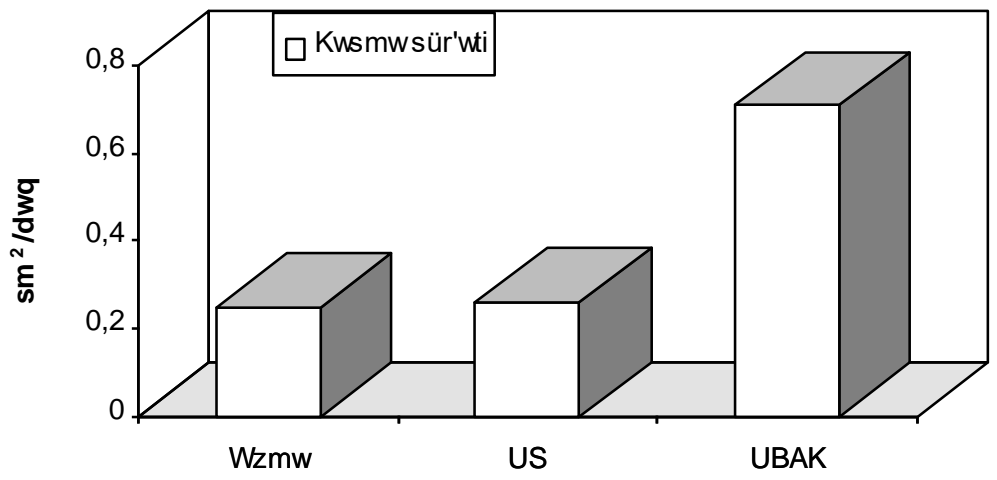

Qrafik 6. 9. Fibrotik qaraciyərlərdə rezeksiya üsulundan asılı olaraq parenximanı kasma sür 'ati 
Beləliklə, fibrotik qaraciyərlərdə aparılan rezeksiyalarda ultrasəs bıçağı əzmə üsuluna nəzərən parenximanın kəsmə sür'ətini artırmadığı halda, UBAK metodunun tətbiqi kəsmə sür'ətni hər iki metoda nəzərən əhəmiyyətli dərəcədə artırmağa və qaraciyəri kəsmə müddətini təxminən 2,7 dəfə azaltmağa imkan vermişdir.

\section{Portal sixac müddoti}

Fibrotik qaraciyərlərin rezeksiyalarında portal s1xaca ehtiyac halları və sıxacın rezeksiya səthinə düşən müddəti əzmə üsulunda $93,1 \%$ və $0,73 \pm 0,06 \mathrm{dəq} / \mathrm{sm}^{2}$, ultrasəs bıçağında $79,1 \%$ və $0,39 \pm 0,03 \mathrm{dəq} / \mathrm{sm}^{2}$, UBAK üsulunda isə uyğun olaraq $56,1 \%$ və $0,17 \pm 0,02 \mathrm{dəq} / \mathrm{sm}^{2}$ təşkil etmişdir (Qrafik 6. 10). Ultrasəs bıçağı əzmə üsuluna nəzərən portal sıxaca olan ehtiyacı və sıxac müddətini əhəmiyyətli dərəcədə azaltmışdır. $(p<0,05)$. UBAK üsulu tətbiq edildiyi hallarda isə portal s1xaca ehtiyac və s1xac müddəti həm əzmə, həm də ultrasəs bıçağına nəzərən əhəmiyyətli dərəcədə azalmışdır (hər iki halda $\mathrm{p}<0,05$ ).

Beləliklə, fibrotik qaraciyərlərin rezeksiyalarında UBAK üsulunun tətbiq edilməsi əzmə və ultrasəs bıçağı üsullarına nəzərən portal sıxaca ehtiyac1 və s1xac müddətini əhəmiyyətli dərəcədə və uyğun olaraq 2 və 4 dəfə azaltmağa, fibrotik qaraciyərlərin işemiyaya daha az mə'ruz qalmasına imkan verir. 


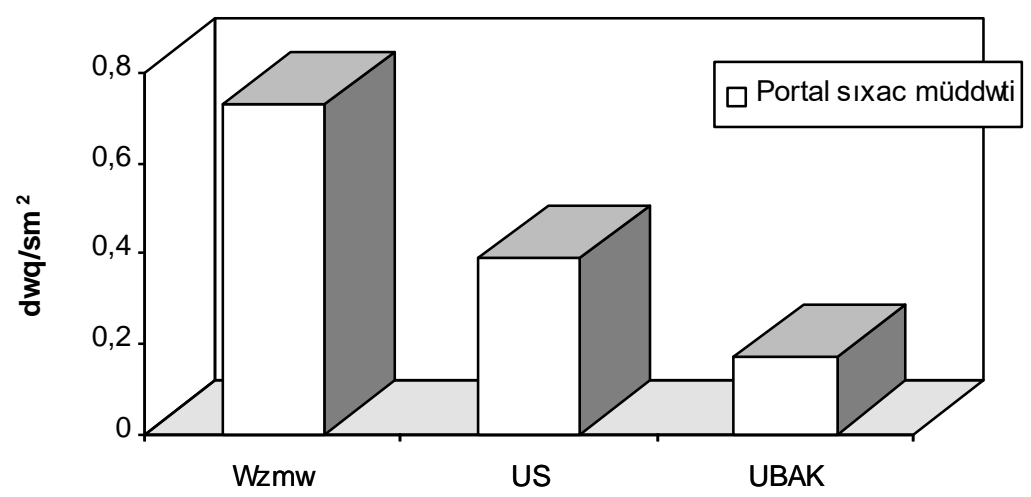

Qrafik 6. 10. Fibrotik qaraciyərlordə rezeksiya üsulundan asılı olaraq portal sixac müddati

\section{Qaraciyər nekrozu}

Fibrotik qaraciyərlərdə aparılan rezeksiyalardan sonra transaminaza səviyyəsinin tədqiq edilməsi göstərir ki, ALT dinamikası hər 3 üsulda bənzər gedir (Qrafik 6. 11). Belə ki, əməliyyatdan sonra ilk gündə enzim səviyyəsi maksimal artır, 3-5-ci günlərdə yüksək səviyyədə davam edir, 7-ci gündə əhəmiyyətli dərəcədə düşərək, 10-cu gündən başlayaraq əməliyyatönü səviyyəyə qədər enir. ALT-nin maksimal artma səviyyəsi UBAK üsulunda

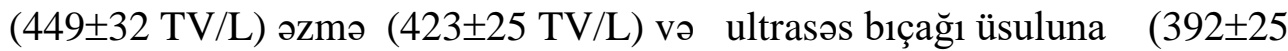
TV/L) nəzərən yüksək olsada onlar aralarındakı fərqlər statistik əhəmiyyəti olmamışdır (hər 3 halda $\mathrm{p}>0,05$ ).

AST səviyəsindəki dəyişikliklər də ALT dinamikasına yaxın olmuşdur. Yə’ni rezeksiya üsulundan asılı olmayaraq AST səviyyəsindəki dəyişikliklər ümumi dinamika üzrə getmişdir: əməliyyatdan sonra birinci 
gündə maksimal artma, 3-5-ci günlərdə yüksək səviyyədə seyr etmə, 7-ci gündə maksimal səviyyəyə nəzərən əhəmiyyətli dərəcədə azalma, 10- cu gündən başlayaraq əməliyyatönü səviyyələrə enmə baş vermişdir (Qrafik 6 . 6). AST-nin maksimal artma miqdarı UBAK üsulunda (513 $\pm 33 \mathrm{TV} / \mathrm{L})$

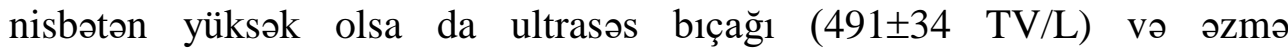

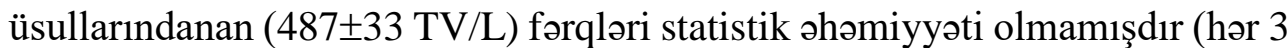
halda $\mathrm{p}>0,05)$.

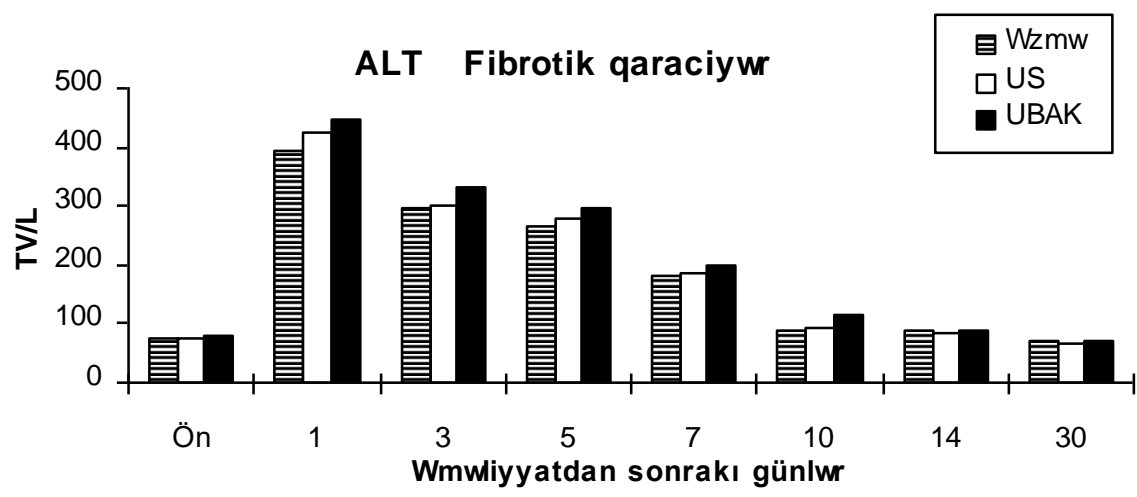

Qrafik 11. Fibrotik qaraciyərlərdə rezeksiya üsulundan asılı olaraq ALT dinamikası 


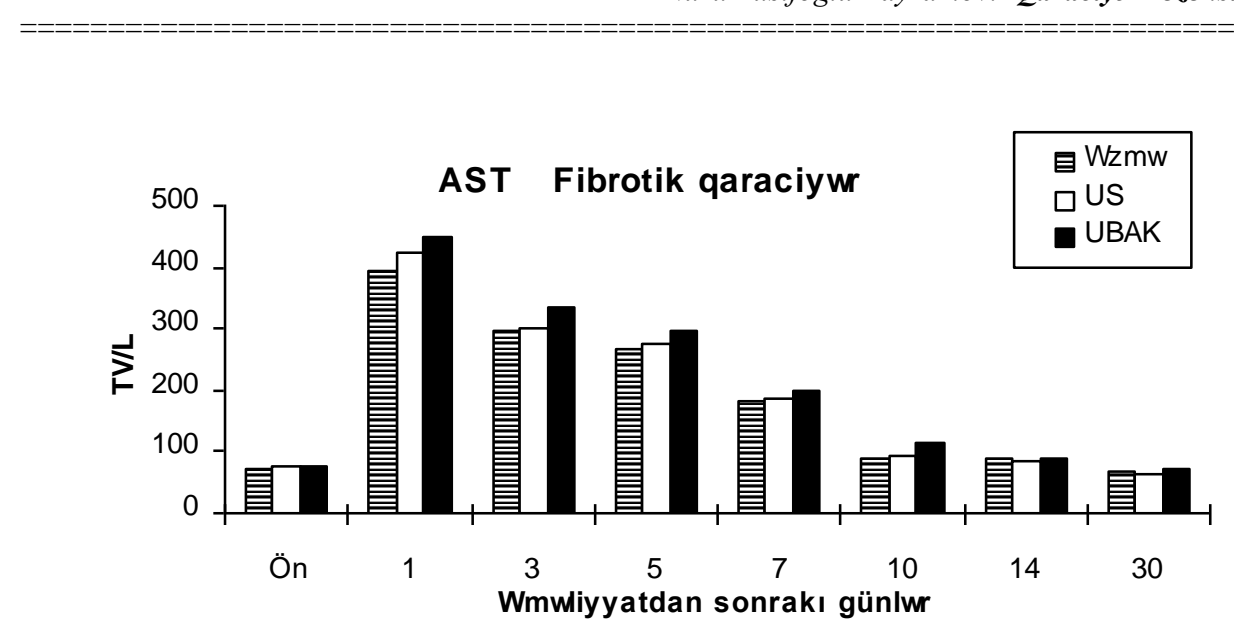

Qrafik 12. Fibrotik qaraciyərlordə rezeksiya üsulundan asılı olaraq AST dinamikası

Beləliklə, qaraciyər nekrozunun biokimyəvi nöqteyi- nəzərdən tədqiqi fibrotik qaraciyərlərdə rezeksiyadan sonra ALT və AST səviyyələrinin maksimal artma miqdarı və dinamikasının rezeksiya üsulundan asılı olmadığını ortaya çıxarmış və bu göstərici əzmə üsulu ilə müqayisədə, ultrasəs bıçağı və UBAK üsullarının qaraciyərdə nekrozu artırmadığını sübut etmişdir.

\section{Patohistoloji göstoricilar}

Patohistoloji tədqiqatın nəticələrinin müqayisəsində nekrozun dərinliyi ultrasəs bıçağı $(14,3 \pm 2,1 \mathrm{~mm})$ ilə yerinə yetirilən rezeksiyalarda daha az olmuşdur. Ancaq bu üsulla əzmə $(19,3 \pm 3,2 \mathrm{~mm})$ və UBAK üsulları $(21,7 \pm 2,6 \mathrm{~mm})$ arasında statistik əhəmiyyətli fərqlər ortaya çıxmamışdır (bütün hallarda $\mathrm{p}>0,05$ ).

Beləliklə, həm biokimyəvi həm də patohistoloji meyarlar əzmə üsulu ilə müqayisədə ultrasəs bıçağı və UBAK üsullarının fibrotik qaraciyərlərdə rezeksiya vaxtı törədilən nekrozun səviyyəsini ciddi artmadığını təsdiq etmişdir. 


\section{A ̌̆ırlaşmalar}

Fibrotik qaraciyəri olan xəstələrdə rezeksiyadan sonra ağırlaşmalar cəmi 37 xəstədə $(35,9 \%)$ rast gəlmişdir. Әzmə üsulu ilə yerinə yetirilən rezeksiyalarda ağırlaşma $15(51,7 \%)$ xəstədə, ustrasəs bıçağı üsulunda 14 $(32,5 \%)$, UBAK ilə aparılan rezeksiyalarda isə $8(19,5 \%)$ təsadüf etmişdir. Yə’ni, əzmə üsuluna nəzərən fibrotik qaraciyərdə ultrasəs bıçağı ağılaşmaları nisbətən, UBAK üsulu isə ciddi şəkildə $(\mathrm{p}<0,05)$ azaldır (Cədvəl 6. 8).

Cadval 6.8

Fibrotik qaraciyardo aparlan rezeksiyalardan sonra baş verən ă̆ırlaşmaların rezeksiya üsuluna göra paylanması.

\begin{tabular}{|l|c|c|c|}
\hline & $\begin{array}{c}\text { Ozmə } \\
\mathrm{n}=29\end{array}$ & $\begin{array}{c}\text { UB } \\
\mathrm{n}=43\end{array}$ & $\begin{array}{c}\text { UBAK } \\
\mathrm{n}=41\end{array}$ \\
\hline A ğırlaşma halları & $15(51,7 \%)$ & $14(32,5 \%)$ & $8(19,5 \%)^{*}$ \\
\hline
\end{tabular}

*- $p<0,05$ azmə üsuluna nəzərən

Rezeksiya üsullarının ağırlaşmalar üzrə aparılan ümumi müqayisəsində mühüm nəticələr ortaya çıxmışdır. Cəmi 46 xəstədə $(27,8 \%)$ 87 ağırlaşma, 17 xəstədə isə (10,3\%) ölüm qeyd edilmişdir. Mə’lum olmuşdur ki, ultrasəs bıçağı və UBAK üsulları əzmə üsuluna nəzərən həm ağırlaşma, həm də ölüm hallarını azaltmışdır (Codvol 6. 9). Ağırlaşmaların xarakteri üzrə aparılan müqayisədə görünür ki, ultrasəs bıçağı və UBAK bütün ağırlaşmaları, xüsusən də qaraciyər yetməzliyi, intraabdominal qanaxma və ölüm hallarını, UBAK isə bunlarla yanaşı hidrotoraks və öd fisstulu hallarını ciddi şəkildə azaldır. Ultrasəs bıçağı və

Codval 6.9

Rezeksiyadan sonrakı ağırlaşmaların rezeksiya üsulundan asılı olaraq rastgəlmə tezliyi.

\begin{tabular}{|l|l|l|}
\hline Ağırlaşmalar & Rezeksiya üsulu & Cəmi \\
\cline { 2 - 2 }
\end{tabular}


Nuru Yusifoğlu Bayramov. Qaraciyor rezeksiyast

\begin{tabular}{|c|c|c|c|c|c|c|c|c|}
\hline & \multicolumn{2}{|c|}{ Әzmə } & \multicolumn{2}{|c|}{ UB } & \multicolumn{2}{|c|}{ UBAK } & \multirow[b]{2}{*}{ müt } & \multirow[b]{2}{*}{$\%$} \\
\hline & müt. & $\%$ & müt. & $\%$ & müt. & $\%$ & & \\
\hline Qaraciyər yetməzliyi & 8 & 17,7 & 5 & 7,8 & 3 & $5,3^{*}$ & 16 & 9,7 \\
\hline \multirow{2}{*}{ Qastrointestinal qanaxma } & 4 & 8,8 & 2 & 3,1 & - & $-*$ & 6 & 3,6 \\
\hline & 1 & 2,2 & 2 & 3,1 & 1 & 1,7 & 4 & 2,4 \\
\hline Öd fistulları & 3 & 6,6 & 1 & 1,6 & - & $-*$ & 4 & 2,4 \\
\hline İntraabdominal absess & 3 & 6,6 & 1 & 1,6 & 1 & 1,7 & 5 & 3,03 \\
\hline Yaranın irinləməsi & 1 & 2,2 & 1 & 1,6 & - & - & 2 & 1,2 \\
\hline Davamlı assit & 3 & 6,6 & 4 & 6,2 & 1 & 1,7 & 7 & 3,6 \\
\hline İntraoperativ şok & 2 & 4,4 & - & - & - & - & 2 & 1,2 \\
\hline Hidrotoraks & 13 & 28,8 & 11 & 17,1 & 5 & $8,9 *$ & 29 & 17,5 \\
\hline Pnevmoniya & 1 & 2,2 & 1 & 1,6 & 1 & 1,7 & 3 & 1,8 \\
\hline Yayğın damardaxili & & & & & & & & \\
\hline laxtalanma sindromu & 1 & 2,2 & 1 & 1,6 & - & - & 2 & 1,2 \\
\hline Böyrək yetməzliyi & 1 & 2,2 & 1 & 1,6 & 1 & 1,7 & 3 & 1,8 \\
\hline Tromboflebit & 1 & 2,2 & - & - & 1 & 1,7 & 2 & 1,2 \\
\hline Bağırsaq keçməzliyi & 1 & 2,2 & - & - & - & - & 1 & 0,6 \\
\hline Miokard infarktı & - & - & 1 & 1,6 & - & - & 1 & 0,6 \\
\hline Cəmi ağırlaşmaların sayı & 42 & & 31 & & 14 & & 87 & \\
\hline $\begin{array}{r}\text { Cəmi ağırlaşmış } \\
\text { xəstələrin sayı }\end{array}$ & 19 & 42,2 & 17 & $26,5^{*}$ & 10 & $\begin{array}{c}17,8 \\
*\end{array}$ & 46 & 27,8 \\
\hline Ölüm & 8 & 17,7 & 6 & 9,3 & 3 & $5,3^{*}$ & 17 & 10,3 \\
\hline
\end{tabular}

* - p<0,05 azmə üsulu ilə müqayisədə

UBAK üsullarında qaraciyər yetməzliyinin əzmə üsuluna nəzərən azlığının aşağıdakı səbəblərlə izah etmək olar: qanaxma miqdarı, transfuziya miqdar1, portal sıxac müddətinin az olmas1; əməliyyat müddətinin q1salması. UBAK üsulunda hidrotoraks, assit və öd fistulu kimi ağırlaşmaların nisbətən az rast gəlməsini isə arqonlu koaqulyatorun limfa, kapilyar damarları və kiçik öd axarlarını dağlaması ilə əlaqələndirmək olar.

\section{Bölümün yekunu.}


1. Qaraciyərdə quruluş dəyişiklikləri və əməliyyatönü dövrdə qanın laxtalanma sisteminin kənaraçıxmaları rezeksiya üsullarının yararlılığına və rezeksiya nəticələrinə ciddi şəkildə tə'sir göstərir.

2. Rezeksiya üsulundan asılı olmayaraq qaraciyərdə fibrotik dəyişikliklər nekrozu artırır.

3. Normal quruluşlu qaraciyərlərdə və normokoaqulyasiyalı xəstələrdə ultrasəs bıçağı və UBAK üsulları eyni yararlılıq və əzmə üsuluna nəzərən üstün olduqları halda, fibrotik qaraciyərlərdə yalnız UBAK üsulu ən yararlı metoddur.

4. Həm ultrasəs həm də əzmə üsulu ilə rezeksiyalarda qaraciyərin fibrotik dəyişiklikləri və hipokoaqulyasiya normal quruluşa və normokoaqulyasiyaya nəzərən qanaxma şiddəti, transfuziya miqdarı və portal sıxac müddətini artırır, parenximi kəsmə sür'ətini isə azaldır.

5. Ultrasəs bıçağı və əzmə üsulundan fərqli olaraq UBAK üsulu ilə aparılan rezeksiyalarda qaraciyərin quruluş dəyişiklikləri və koaqulyasiya pozulmaları bu metodun yararlılığına ciddi şəkildə tə’sir etmir.

6. Đzmə üsulu ilə müqayisədə ultrasəs bıçağı həm normal quruluşlu, həm də fibrotik qaraciyərlərdə qanaxma şiddəti, transfuziya miqdarı və portal sıxac müddətini azaldır, kəsmə sür'ətini isə normal qaraciyərlərdə artırır, fibrotik qaraciyərlərdə isə ciddi şəkildə dəyişdirmir.

7. UBAK üsulu fibrotik qaraciyərlərdə ultrasəs bıçağı və əzmə üsullarına nəzərən qanaxma şiddəti, transfuziya miqdarı, portal sıxac müddəti və ağırlaşmaları azaldır, kəsmə şür'ətini artırır, normal qaraciyərlərdə isə ultrasəs bıçağına yaxın yararlılıq göstərir. 
VII Bölüm

\section{QARACIYYR REZEKSIYYALARINDAN SONRAKI AĞIRLAŞMALAR}

Qaraciyər rezeksiyası texniki çətinliyi, böyük travmatikliyi, üzun sürməsi, əməliyyatdaxili və əməliyyatdan sonrakı ağırlaşmaların və ölüm hallarının yüksək tezlikdə rast gəlməsi ilə səciyyələnən əməliyyatlar qrupuna aid edilir. İkitərəfli qabırğaaltı, "Mersedes”, bə’zən də torakoabdominal tipli kəsiklərin istifadə olunması, qaraciyər bağlarının kəsilməsi, portal elementlərin sərbəstləşdirilməsi, portal sıxac, 0,5-4 litr qanaxma ilə müşayət olunan parenxima kəsilməsi, çoxlu miqdarda qanköçürülməsi kimi amillər qaraciyər rezeksiyasının texniki çətinliyini, yüksək travmatikliyini göstərir, əməliyyat müddətinin 2-5 saat davam etməsinə səbəb olur. Qaraciyər rezeksiyalarında ağırlaşma hallarının orta hesabla 38\%, ölüm hallarının isə, orta hesabla $14 \%$ xəstədə rast gəlməkdə, və bunlar qaraciyərin əməliyyatönü funksional vəziyyəti və rezeksiya həcmindən asılı olaraq dəyişməkdədir. Normal qaraciyərlərdə aparılan rezeksiyalardan sonra ağırlaşma hallarının 20-30\% xəstədə rast gəldiyi halda, sirrotik qaraciyərdə bu 50-60\% xəstədə müşahidə olunur.

Qaraciyər rezeksiyalarından sonra baş verən ağırlaşmaları klinik olaraq iki qrupa bölmək olar: ümumi və xüsusi ă̆ırlaşmalar. Qaraciyər rezeksiyası üçün spesifik olmayan, cərrahi stress ilə əlaqədar ümumi ağırlaşmalara qan dövranı, tənəffüs, ifrazat, immun, humoral, koaqulyasiya və s. sistemlərdə, su-elektrolit, enerji mübadiləsində, yarada və s. baş verən patoloji prosesləri aid etmək olar. Müasir anestezioloji və intensiv terapiya sayəsində ümumi ağılaşmalar kəskin azalaraq 5\%-ə qədər enmişdir. Xüsusi ağırlaşmalara isə, birbaşa olaraq qaraciyər rezeksiyası əməliyyatı ilə əlaqədar törənən əməliyyatdaxili və əməliyyatdan sonrakı ağırlaşmaları aid etmək olar. Xüsusi ağılaşmaların əksəriyyətinin çoxsəbəbli olmasına baxmayaraq, onları baş vermə səbəbinə görə iki əsas qrupa ayırmaq olar: rezeksiya texnikası ilə 
olaqədar baş verən ă̆llaşmalar vo qaraciyərin morfo-funksional çəhətdən azalması ila alaqdar ortaya çıxan ă̆ıılaşmalar (Səkil 7.1).

Swkil7.1. Qaraciywr rezeksiyalarındakı ağırlaşmaların twsnifatı

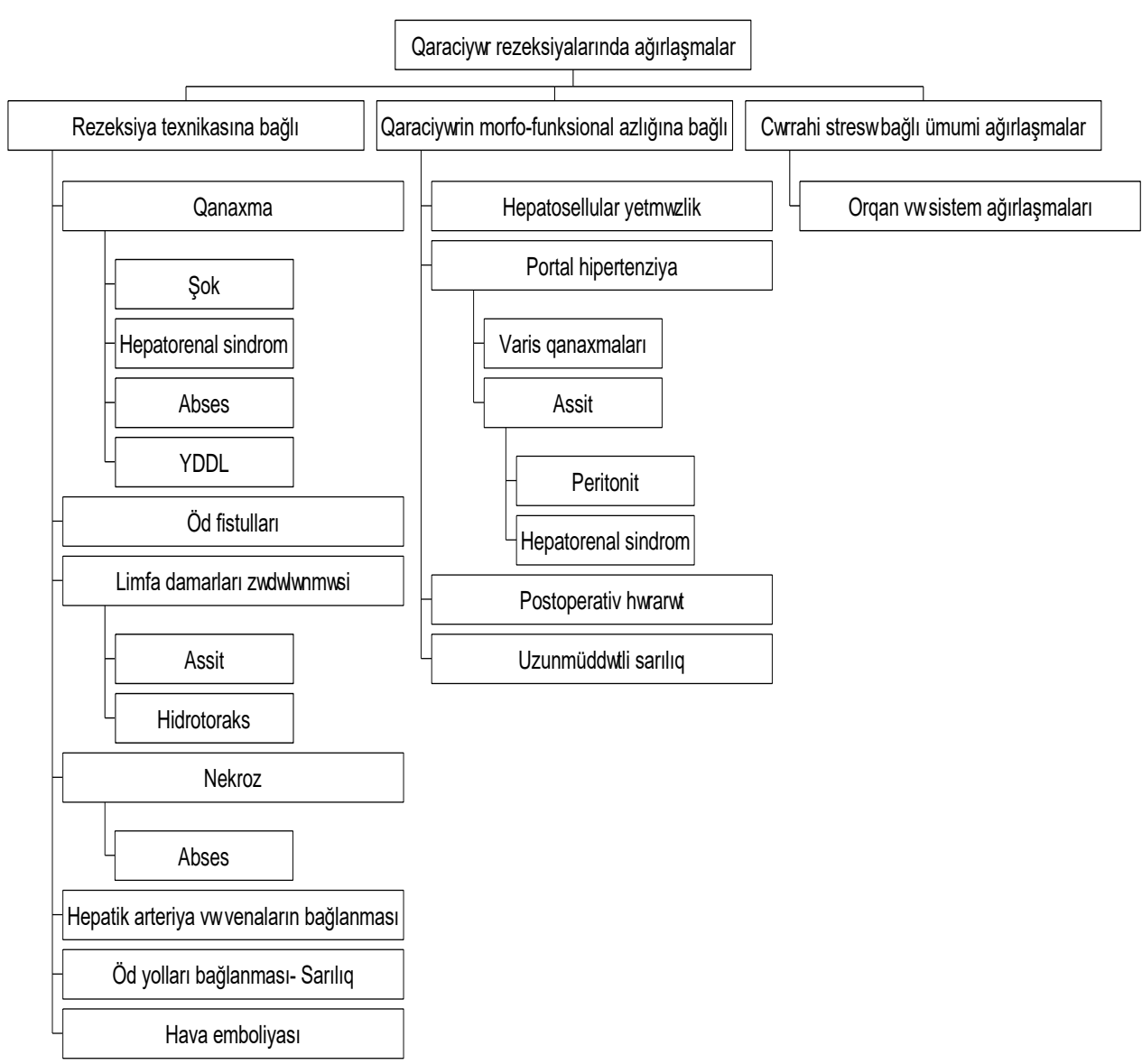

QANAXMALAR

Rezeksiya vaxtı baş verən böyük qanaxmalar on ciddi ağırlaşmalardan biri hesab edilir. Çünki, bir tərəfdən kəskin qan azlığına bağlı şok və yayğın damardaxili laxtalanma meydana gələ bilir ki, bunlar da 
əməliyyatdan sonrakı multiorqan və sistem yetmezliklərinə səbəb ola bilir. Diğər tərəfdən əməliyyat vaxt1 0,5 litirdən çox olan qanaxmalarda çoxlu miqdarda qan köçürmək lazım gəlir ki, bu da intoksikasiya, laxtalanma pozulmaları, immun reaksiyar, virus infeksiyaları ilə yoluxma kimi arzuolunmaz nəticələr verə bilir, qalan qaraciyərin yükünü artırır (Şəkil 7.2). Hətta, qanköçürmənin şiş hüceyrələrinin çoxalmasını, qaraciyər xərçənginin residiv vermə ehtimalını artırdığı da mə'lumdur.

Rezeksiya vaxtı qanaxmalar başlica olaraq iki əsas səbəblə əlaqədar baş verir. Birincisi, nisbətən böyük damarların yetərli bağlanmaması və ya böyük damarların zədələnməsi ki, bunlar başlıca olaraq texniki səbəblərlə əlaqədardır. Ikkincisi isə, kapillyar qanaxmasıdır ki, bunun da başlica səbəbləri ya əməliyyatdan əvvəl mövcud olan, ya da əməliyyat vaxtı baş veren yayğın damardaxili laxtalanma nəticəsində meydana gələn hipokoaqulyasiyadır. Böyük həcmli qanaxmalar yayğın damardaxili laxtalanma sindromu törədir, bu isə, kapillyar qanaxmasına səbəb olaraq qanaxmanı davam etdirir və qüsurlu patoloji dövran meydana gəlir.

Klinika və diaqnostikası. Qanaxmanın klinik gedişini axan qanın miqdar1 və intensivliyi müəyyən edir. Qanaxma yerli və ümumi əlamətlərlə özünü biruzə verir. Yerli əlamətlərə əməliyyat vaxtı görünən qanaxma, amaliyyatdan sonra drenajdan qangalma, ultrasəs müayinəsi (USM), bilgisayarl tomoqrafiya (BT) vo punksaiyada qarın boşluğunda qanın olması aid edilir. Ümumi əlamətlərin əsasında isə, qanın ümumi həcmindəki (hipovolemiya) va formalı elementlarin miqdarındakı (qanın konsentrasiya göstəricilərində azalma) dəyişikliklər durur (Cədvəl 7.1). Hipovolemiya dərinin avazıması, nəbzin tezləşməsi, arterial və venoz təzyiqin azalması, diurezin azalması kimi göstəricilərlə qiymətləndirilir. 

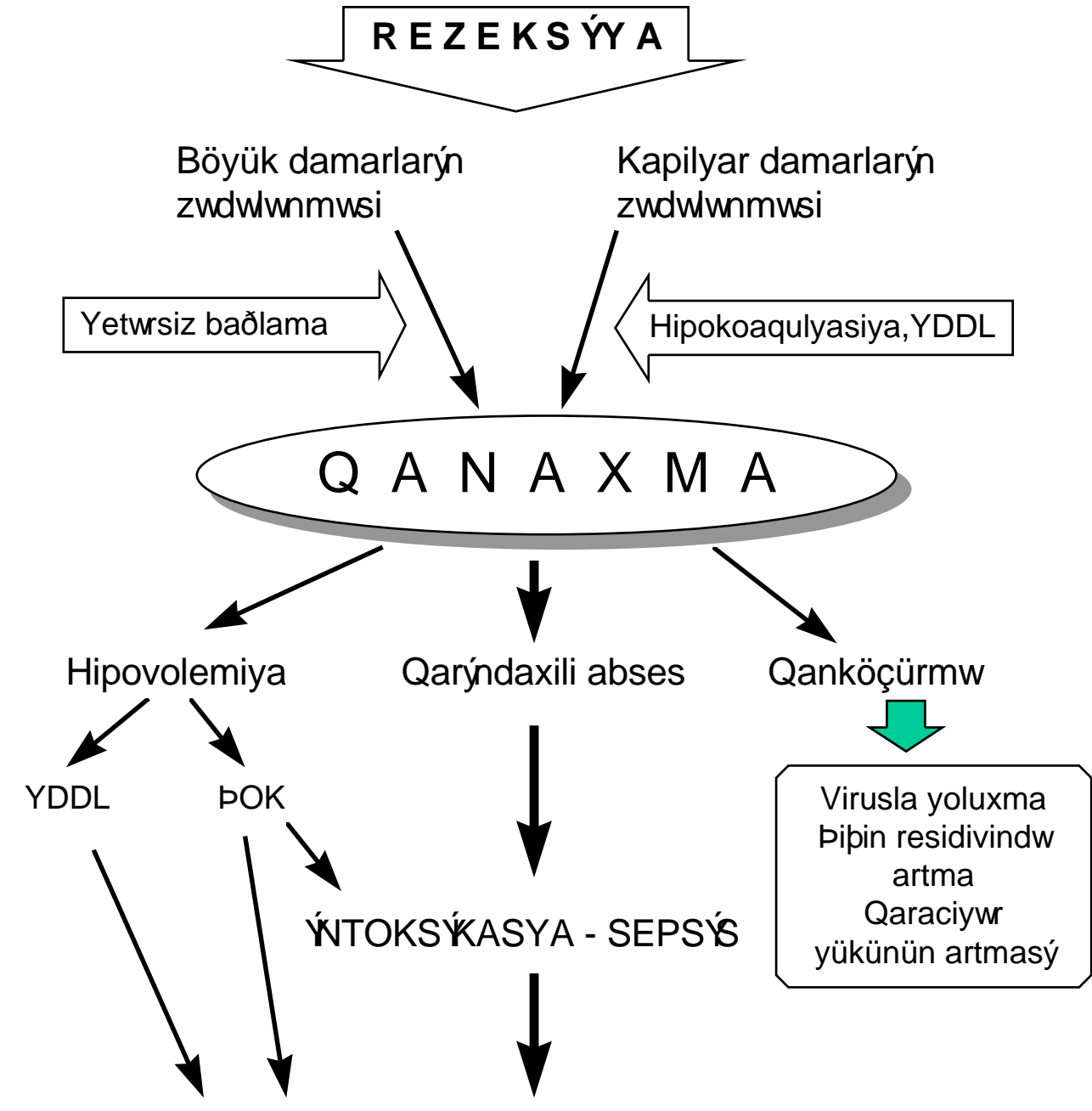

Qanköçürmw

ORQAN YETMWZLḰLLWÝ

Şəkil 7.2. Qaraciyər rezeksiyasında qanaxmanın etiopatogenezi

Qanın konsentrasiya göstəriciləri kimi hemoqlobin miqdarı $(\mathrm{Hb})$ və hematokrit $(\mathrm{Ht})$ istifadə olunur. Oməliyyat vaxtı və əməliyyatdan sonrak1 
qanaxmalarda xəstədə infuziyon terapiya aparıldığı üçün hemodinamik göstəricilər bariz olmaya bilir. Bu hallarda qanaxmanı qiymətləndirmək üçün konsentrasiya göstəricilərindən istifadə edilir. $\mathrm{Hb}$ və $\mathrm{Ht}$ göstəricilərinin azalmağa davam etməsi, qan köçürülməsinə baxmayaraq $\mathrm{Hb}$ və $\mathrm{Ht}$ artmaması və ya $500 \mathrm{ml}$ qan köçürdükdə Ht-in 3 vahiddən az artması, xəstəyə 24 saat ərzində 1500 ml-dən çox qan köçürüşməsi davam edən qanaxmanın xarakteristik əlamətlərindən hesab edilir. Lakin, xəstəyə çoxlu miqdarda maye köçürülərsə konsentrasiya göstəriciləri dəqiq olmaya bilir. Ona görə də, konsentrasiya göstəriciləri düzgün nəticəni hemodinamik göstəricilər normal olduğu zaman verir.

Cadvəl 7.1

Rezeksiya olunan xəstəlardə qanaxmaya nəzarət üçün göstəricilar.

\begin{tabular}{|c|c|}
\hline \multirow{2}{*}{\multicolumn{2}{|c|}{$\begin{array}{l}\text { Göstoricilar } \\
\text { Yerli alamotlar }\end{array}$}} \\
\hline & \\
\hline Baxma & Qanaxmanın görünməsi* \\
\hline USM, BT & Drenajdan qan galmə* \\
\hline Drenaj və möhtəviyyatı & Qarında qan* \\
\hline Punksiya & Punktatda qan* \\
\hline \multicolumn{2}{|l|}{ Hemodinamika göstoricilori } \\
\hline Dərinin rongi & Avazımış \\
\hline Nəbz & $>100$ \\
\hline AT & $\begin{array}{l}<90 \mathrm{~mm} \text { Hg st., Alqover indeksi } \\
(\text { Nobz/AT) }<1\end{array}$ \\
\hline Mərkəzi venoz təzyiq & $<0 \mathrm{~mm} \mathrm{Hg} \mathrm{st}$ \\
\hline Diurez & $<0,5 \mathrm{ml} / \mathrm{d} ə \mathrm{q}$ \\
\hline \multicolumn{2}{|l|}{ Konsentrasiya göstoricilori } \\
\hline Hemoqlobin & Azalmaqda davam edir, $<90 \mathrm{q} / 1$ \\
\hline Hematokrit & Azalmaqda davam edir, $<25$ \\
\hline Qanköçürməyə cavab & $\begin{array}{l}500 \mathrm{ml} \text { qan köçürülməsinə baxamayaraq } \\
\text { Ht } 3 \text { vahiddən az artır. }\end{array}$ \\
\hline * qanaxmanin mütlaq alamətlari & \\
\hline
\end{tabular}


Qaraciyər rezeksiyasından sonrakı ă̆ırlaşmalar

Müalicəsi. Qanaxmanın effektiv müalicəsi üçün mə’lum olan iki əsas prinsip həyata keçirilməlidir: qanaxmanı dayandırmaq vo bərpa- axmış qanı əvoz etmok.

Qanaxmanın dayandırılması üçün qanaxan damarın bağlanması və laxtalanma sisteminin normallaşdırılması əsas şərtdir. Qanaxma nəticəsində həm damardaxili qanın ümumi miqdarı, həm də qanın oksigen daşıma qabiliyyəti - hemoqlobin miqdarı azaldığı üçün, əvəzedici tədbirlər damardaxili mayenin həcmi və hemoqlobin miqdarının bərpasına istiqamətləndirilir. İlk növbədə damardaxili qanın həcmi bərpa olunur və bunun üçün kristalloid və kolloid (2:1) məhlullar istifadə olunur. Qanın ümumi həcminin qiymətləndirilməsində hemodinamik göstəricilər əsas götürülür. Mərkəzi venoz təzyiqin 0-5 mm Hg st., arterial təzyiqin >100 mm $\mathrm{Hg}$ st., diurezin $>0,5 \mathrm{ml} /$ dəq. olması lazımdır. Mümkün olduğu hallarda dövr edən qanın həcminin ölçülməsi də yararlı ola bilir.

Qanın oksigen daşıma qabiliyyətinin bərpası üçün tam qan və ya eritrosit kütləsi köçürülür. Kiçik qanaxmalarda $(<500 \mathrm{ml})$ qan və eritrosit kütləsi köçürülməsinə ehtiyac yoxdur, böyük qanaxmalarda (> $1000 \mathrm{ml})$ isə, qanköçürmə mütləq lazımdır.

Qanazlığında orqanizmin cavab reaksiyası kimi qan dövranı sür’ətlənir və toxumaların oksigen təllabatını ödəməyə

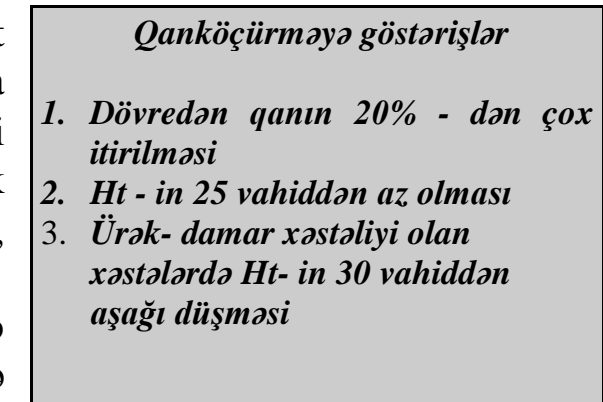
çalışır. Lakin, Ht səviyyəsi kapillyar qandakı səviyyədən (25 vahid) aşağıya düşdükdə toxumalarda oksigen aclığı başlayır. Ona görə də hematokritin 25 vahidi kritik səviyyə hesab edilir. Ürək-damar xəstəliyi olanlarda kompensator imkanlar tükəndiyi üçün qan dövranının sür’ətlənməsi zəif olur, az miqdar qanaxma şok hadisəsi törədə bilir. Ona görə də bu xəstələrdə hematokritin 30 vahiddən aşağı düşməsi təhlükəlidir. 
Omoliyyatdaxili qanaxmanın profilaktikası vo dayandırılmast. Oməliyyat zamanı qanaxma qaraciyərdaxili damarlardan, və qaraciyərə girən və çıxan magistral damarlardan və Qaraciyor rezeksiyası vaxtı qanaxmanın profilaktikası şaxələrindən ola bilir. Qaraciyər daxilində qap1 venas1, qaraciyər arteriyası şaxələri və öd axacaqları ümumi bir q1lıfla örtülü olur. Ona görə də, parenxim kəsilərkən adətən bunlar birlikdə bağlana bilirlər. Qaraciyər venalarının isə, q1lifi olmur.

\section{Qaraciyər}

rezeksiyas1

vaxt1

qanaxmanın

profilaktikası

dayandırılmasında ssas

prinsip qaraciyardon

xaric damarlarin

ehtiyatla ayrlmast vo

nozarati,

qaraciyardaxili

damarlarların görərək

bağlanmast, vo qanın

laxtalanma sisteminin

normal vaziyyatdo

tutulmasıdır. Aşağıdakı

şərtlərin

yerinə

yetirilməsi rezeksiya

vaxtı qanaxmanın azaldılmasına imkan verir.

\section{todbirlori}

1. Qaraciyərə daxil olan və çıxan magistral damarlar ehtiyatla ayrılmalı və nəzarətdə saxlanılmalıdır.

2. Çıxarılacaq hissənin (pay, sektor, seqment) gətirici damarları parenxim kəsilməsindən əvvəl bağlanılmalıdır. $\mathrm{Bu}$ həm çıxarılacaq bölgənin sərhədlərini daha dəqiq müəyyən etməyə, həm də qanaxmanı azaltmağa imkan verir.

3. Qapı elementlərinin sıxılması işləmi (Pringler manevri) üçün imkan yaradılmalı və lazım gəldikdə yerinə yetirilməlidir. Bunun üçün qaraciyər-onikibarmaq bağırsaq bağının nəzarətə alınması tövsiyə olunur.

4. Qaraciyər venalarının ekstrahepatik hissəsinin yox, intrahepatik hissəsinin sərbəstləşdirilməsi tövsiyə olunur. Xüsusilə venaların aşağı boş venaya açılan yerində ehtiyatlı olmaq lazımdır.

5. Qaraciyərdaxili damarları zədələməmək və daha diqqətli bağlamaq üçün, onları parenximadan ayırmaq və görərək bağlamaq lazımdır. Bunun üçün parenximanı kəsərkən ayırma texnikasını, xüsusən ultrasəs bıçağını istifadə etmək daha əlverişlidir.

6. Qaraciyərdaxili venaları zədələməmək üçün onların yerini ultrasəslə müəyyən etmək və ya kəsiyi təxmini proeksiyalarından $1 \mathrm{sm}$ kənarda aparmaq lazımdır.

7. Kapillyar qanaxmanın qarşısını almaq üçün əməliyyatönü dövrdə koaqulyasiya sisteminin vəziyyətin normallaşdırmaq, böyük qanaxmalara yol verməmək, yayğın damardaxili qanaxmanı müalicə etmək lazımdır. kapillyar qanaxmanı önləmək və dayandırmaq üçün koaqulyatorların istifadəsi faydalıdır. 
Qaraciyər rezeksiyasından sonrakı ă̆ırlaşmalar

Qapı venası zədələndikdə Pringler manevrası ilə qanaxma dayandırıldıqdan sonra zədələnən sahə ətraf toxumalardan sərbəstləşdirilir və yaraya atravmatik damar tikişləri $(06,07)$ qoyulur.

Qaraciyər arteriyası zədələndikdə mikrocərrahiyə imkanları yoxdursa damar bağlana bilər. Bu halda kolleteral dövranın tə’mini üçün bağlanma mümkün qədər proksimalda aparılmalı və qaraciyər qapısı az ayrılmalıdır.

Qaraciyərdaxili damarlardan baş verən qanaxmanı dayandırmaq üçün istifadə olunan üsullar damar çapından asılı olaraq dəyişir. Kiçik (çapı <2 $\mathrm{mm}$ ) damarlardan baş verən qanaxmaların yeri sorucu ilə müəyyən edilir və koaqulyatorla dağlanır. Güclü qanaxmalarda Pringler manevri ilə qanaxma azaldılır, sorucu ilə qanaxma yeri müəyyən edilir, qanaxan damar parenximadan ayrılır və bağlanılır. Ogər bağlanan damar seqment şaxəsi olarsa bağlandıqdan sonra uyğun seqmentdə rəng dəyişikliyi meydana gəlir və bu seqmentin çıxarılması lazımdır.

Pringler manevrası ilə durmayan qanaxmalar adətən qaraciyər venalarından olur, çünki bu venalarda qapaq olmadığı üçün aşağı boş venadan retroqrad qan axımı mövcuddur. Ona görə də bu halda qanaxma üzərinə və ətrafına basılaraq dayandırılır. Qaraciyər venalarının divarı nazik olduğu üçün tikiş qoyulması çətinlik törədir. Ona görə də bə’zən zədələnmiş venanın bağlanması lazım gəlir. Qaraciyər venaları distalda bağlanarsa təhlükə törətmir, proksimalda, xüsusən də boş venaya açılan yerdə bağlanarsa uyğun pay və ya sektorda venoz axın pozula bilir. Sol vena bağlanarsa II və III seqment çıxarılmalıdır. Sağ vena bağlanarsa VII seqment çıxarıla bilər, VI seqment isə, çıxarılmamalıdır, çünki bə'zən (20\%) bu seqmentdən aşağı boş venaya birbaş şaxələr gedir. Orta ven zədələnərsə IV, V və VIII seqmentlərdə venoz axın pozula bilər. Vena bağlandıqdan sonra seqmentdə rəng dəyişikliyi və şişmə baş verərsə onun çıxarılması lazımdır.

Kapillyar qanaxma kəsik səthindən yavaş, nöqtəvi, "hər tərəfdən baş verən" qanaxma şəkilində olur. Normal halda kapillyar zədələnərsə əmələ gələn "trombositar tıxac" və qan laxtası mənfəzi tutur, təzyiq az olduğu üçün bu tıxaclar yuyulmur və "atmır". Lakin laxtalanma zoifliyi və ya hiperfibrinoliz olan hallarda kapillyar mənfəzi tıxanmır və qanaxma davam edir. Bu hala daha çox yayğın damardaxili laxtalanma (YDDL) sindromunda rast gəlinir. Kapillyar qanaxma yavaş olmasına baxmayaraq, çox təhlükəlidir 
və dayandırılması çətindir. Bu halda YDDL müalicəsi başlanır (heparin, təzə plazma), Pringler manevrası ilə qanaxma azaldılır, kəsik səthi qurudulur və koaqulyatorla incə təbəqə şəkilində dağlanır. Bu effektzis olarsa əməliyyat mümkün qədər tez tamamlanır və ya dayandırılır, kəsik səthinə tamponlar qoyularaq qanaxma dayandırılır və qarın boşluğu bağlanılır. Laxtalanma sistemi korreksiya olunarsa xəstə 48 saat sonra təkrar əməliyyat edilir və tamponlar çıxarılır (və ya əməliyyat davam etdirilərək tamamlanır).

Kosik sothindən kapillyar vo diğər tipli qanaxmalart
dayandırmaq üçün “yorğan", “U”, “Z” vo s. şəkilli hemostatik
tikişlorin qoyulması tövsiyo edilmir. On güvonli üsul damarın
parenximadan ayrılıb bağlanılmasıdır.

Oməliyyatdan sonrakı dövrdo qanaxma liqaturanın açılması nəticəsində böyük damarlardan və ya laxtalanma pozulmaları ilə əlaqədar kapillyar damarlardan baş verə bilir. Qanaxmanın klinik gedişi, diaqnostikası və nəticəsi axan qanın miqdarı və intensivliyindən asılı olaraq dəyişir (Şəkil 7.3). Kiçik qanaxmalar klinik biruzə vermədən spontan olaraq dayana bilər, axmış qan rezorbsiya və ya infeksiyalaşa bilir. Böyük və intensiv qanaxmalar kəskin anemiya, hemorragik şok törədə bilir.

Drenajdan qan gəlməsi qanaxmanı göstərən kriteriya olmasına baxmayaraq bu əlamətin olmaması qanaxmanı inkar etməz, çünki, drenaj qatlana bilər, trombla tutula bilər və ya uyğun yerdə olmaya bilər. Drenajın yuyulması hər zaman müsbət nəticə verməyə bilir. Ona görə də əməliyyatdan sonrakı qanaxmanın diaqnostikasında ən yararlı göstərici qanın konsentrasiya q1ymətlərində davam edən düşmə USM və ya BT-də qarın boşluğunda qanın müəyyən edilməsidir. USM və ya BT altında punksiya diaqnozu dəqiqləşdirə bilər. 


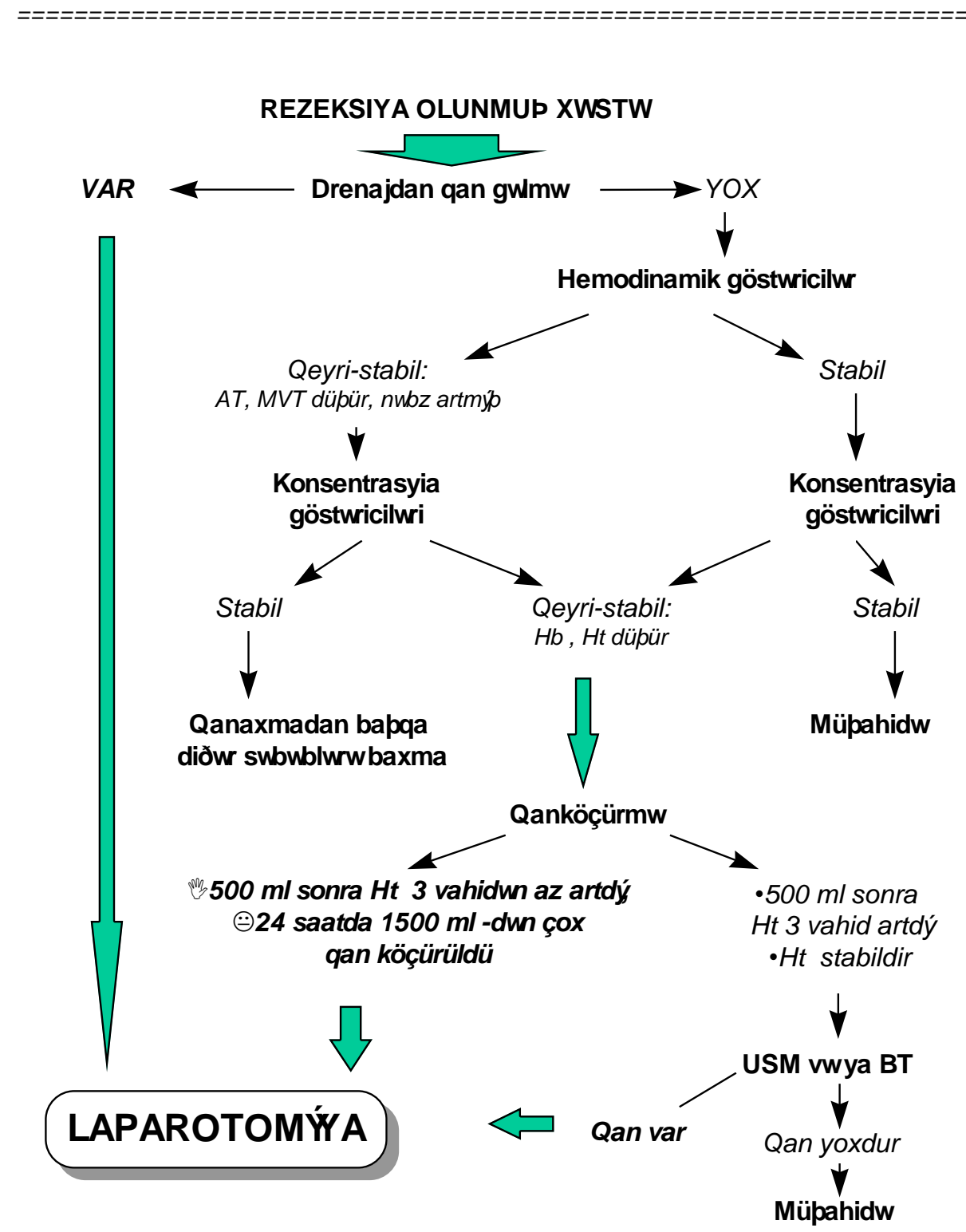

Şəkil 7.3. Rezeksiyadan sonrakı qanaxmalarda diaqnostika vo müalicə taktikası 
Laparoskopiya əməliyyatdan sonrakı dövrdə tövsiyə olunmur, çünki, qanaxma qaraciyər venalarından olarsa hava emboliyası yarana bilər.

Oməliyyatdan sonrakı qanaxmaların müalicəsi üçün relaparatomiya, qanaxan damarın bağlanması, qanın təmizlənməsi və dövr edən qanın bərpası lazım gəlir. Qarına toplanan qanın infeksiyalaşması ehtimalı yüksək olduğu üçün, hətta dayanmış qanaxmalarda da əməliyyat lazımdır. Bə’zi hallarda relaparotomiyada qanaxan damar tapılmaya bilir. Laxtalanma pozulması ilə əlaqədar olan kapillyar qanaxmaların müalicəsi yuxarıda qeyd edilmişdir.

\section{HAVA EMBOLIYASI}

Hava emboliyası qaraciyər venalarının və ya aşağı boş venanın zədələnməsi nəticəsində baş verən nadir $(<1 \%)$, lakin təhlükəli ağırlaşmadır. Damarı zədələməmək, ağciyər ventilyasiyasını aşağı təzyiqlərdə aparmaq profilaktik tədbirlərdir. Emboliya baş verdikdə isə, xəstənin baş tərəfini aşağ 1 salmaq, kardio-pulmonar intensiv terapiya məsləhət görülür.

\section{HIDROTORAKS}

Hidrotoraks qaraciyər rezeksiyalardan sonra ən çox təsadüf edilən ağırlaşmalardandır və təxminən $24 \% \quad(12-81 \%)$ hallarda rast gəlir. Hidrotoraksın əmələ gəlməsinində bir neçə mexanizmin rolu vardır: rezeksiyadan sonra hipoalbuminemiya və onkotik təzyiqin azalmas1; qaraciyər, retroperiton və plevra arasında limfa axınını tə'min edən, qaraciyər bağlarında, retrohepatik bölgədə və diafraqmada yerləşən limfa damarlarının əməliyyat vaxtı zədələnməsi; qarındaxili təzyiqin plevradaxili təzyiqdən yüksək olması nəticəsində limfanın plevra boşluğuna keçməsi; diafraqmadkı və diafraqma altı bölgədəki aseptik və ya septik iltihabla əlaqədar reaktiv plevrit: xəstənin yataq rejimi və s. (Şəkil 7.4). 


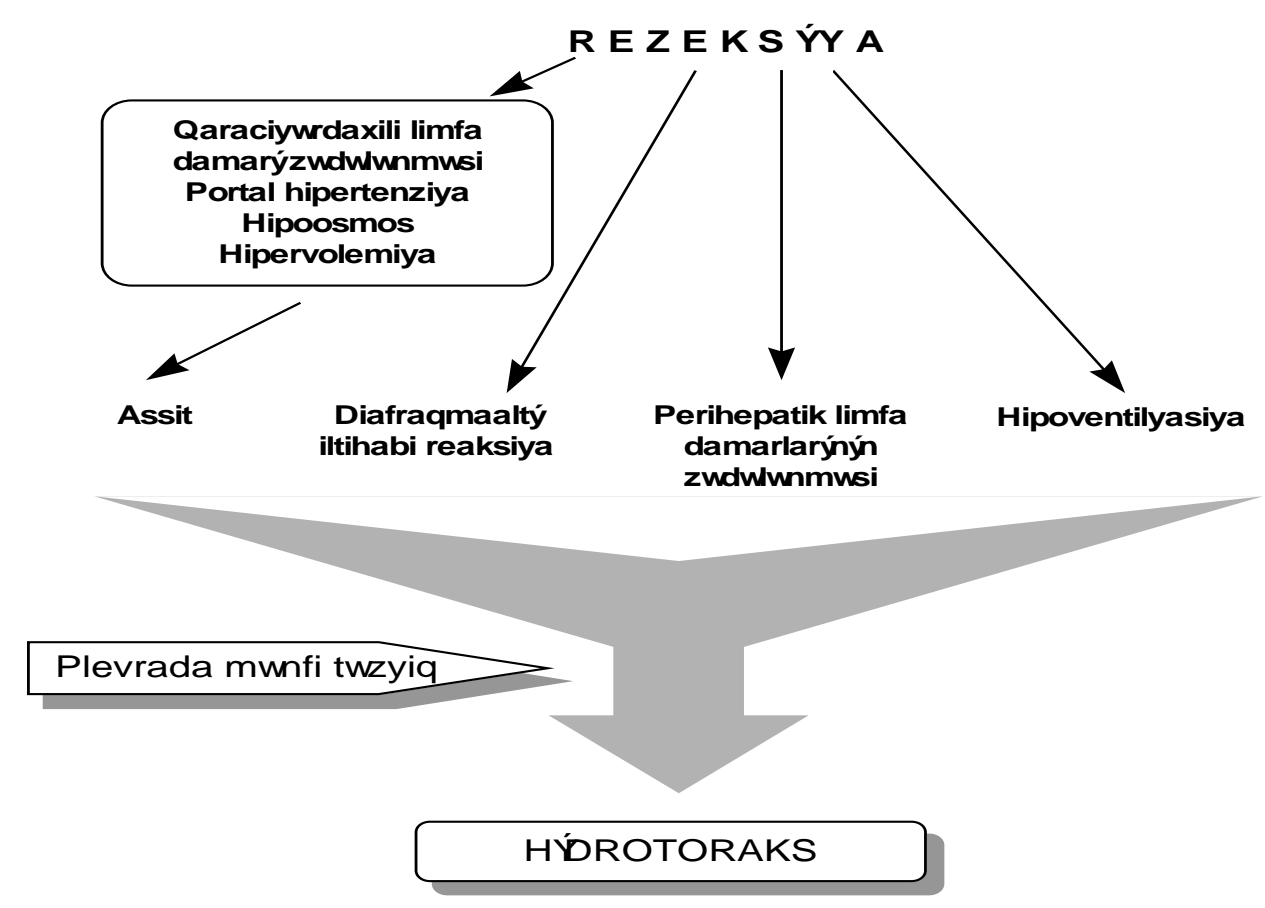

Şəkil 7.4. Postrezeksiyon hidrotoraksın etiopatogenezi

Hidrotoraks ağciyər funksiyasını pozduğu və infeksiyalaşma ehtimalı yüksək olduğu üçün onun profilaktikası və vaxtında müalicəsi vacibdir. Hidrotoraksın profilaktikası üçün erkən fiziki aktivlik, tənəffus hərəkətləri, albumin köçürülməsi, hətta mexaniki ventilyasiyanın 24 saata qədər davam etdirilməsi, qaraciyrin rezeksiya səthinə və bağların kəsilən yerlərinə fibrin yapışqanı tövsiyə olunur. Müalicəsi, hidrotoraksın miqdarından, gedişindən və infeksiyanın olub olmamasından asılıdır. Kiçik həcmli, sinus səviyyəsində olan və artmayan hidrotorakslar simptomsuz gedir, ciddi müalicə tələb etmədən bir neçə gün içərisində sorulurlar. Artan, böyük həcmli və ya infeksiyalaşmış hidrotorakslar tənəffüs yetməzliyi və/və ya septik əlamətlərlə biruzə verir, punksiya, drenj, antibiotikoterapiya, diuretiklər, albumin köçürülməsi kimi tədbirlər tələb edirlər (Şəkil 7.5). 


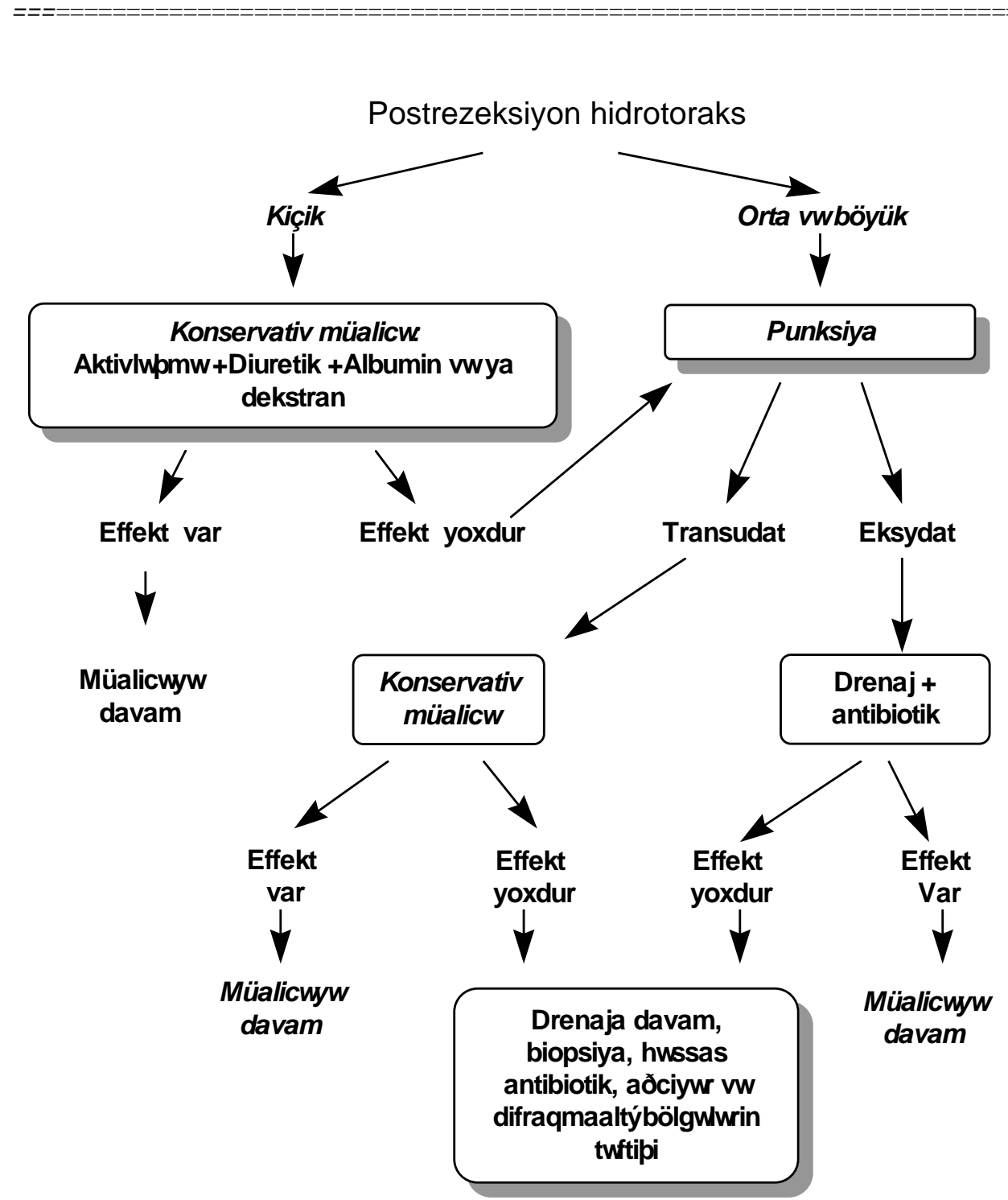

Şəkil 7.5. Postrezeksiyon hidrotoraksın müalico taktikası

ASSIT 
Qaraciyər rezeksiyasından sonrakı ă̆ırlaşmalar

Assitin böyük həcmli rezeksiyalarda və sirrotik xəstələrin əksəriyyətində rast gəlməsin baxmayaraq onun klinik biruzə verən forması 25\%-35\% xəstədə müşahidə edilir.

Postrezeksion assitin əmələ gəlməsində üç başlıca mexanizminportal hipertenziya, böyrəklərdən su va natrium ifrazının azalması və qanın onkotik təzyiqinin azalması- rolu olduğu mə'lumdur ki, bunlar da aşağıdakı patogenetik faktorlarla əlaqədar olaraq ortaya çıxırlar: rezeksiya nəticəsində qapı venasının qaraciyər yatağının azalması və ya portal vena, hepatik venada tromboz ilə əlaqədar portal hipertenziya və ya mövcud portal hipertenziyada artma; albumin sintezində azalma və qanın onkotik təzyiqinin azalmas1; qaraciyərdaxili və qaraciyərətrafı limfatik damarların zədələnməsi; antidiuretik hormonun inaktivasiyasında azalma və böyrəklərdən su ifrazının azalmas1; hipovolemiya nəticəsində renin-angiotenzin sistemində fəallaşma və natrium retensiyası (Şəkil 7.6).

Klinik olaraq, assit yünğül (asimptomatik, ultrasəs və ya tomoqrafik müayinələrlə müəyyən edilən kiçik həcmli assitlər), orta (qarında şişmə və maye əlamətləri, drenajdan və ya drenaj yerindən assit ifrazı) və ağır (gərgin qarın, təngənəfəslik, bakterial peritonit əlamətləri) dərəcəli gedişlə özünü göstərə bilir. Klinik əlamətlərlə yanaşı, ultrasəs və ya tomoqrafiya qrında mayenin olmasını, mayenin biokimyəvi, sitoloji və mikrobioloji müayinəsi assitin xarakterini müəyyən etməyə imkan verir. Mayedə zülalın 2,5 g/dl-dən az olması, laktat dehidrogenaza aktivliyinin 250 TV/1-dən az olması, xüsusi çəkinin 1016-dan az olmas1, leykositlərin 250/mkl-dən az olması, bilirubin səviyyəsinin plazmadakından az olması assit əlamətlərini göstərir. Zülal $>3 \mathrm{~g} / \mathrm{dl}$, leykositlər $>250 / \mathrm{mkl}$ peritonitin inkişaf etdiyini, bilirubin səviyyəsinin plazmadan yüksək olması isə, öd fistulunu göstərir. Yüngül və orta dərəcəli assitlərdə antiassitik müalicə (su və natriumun az verilməsi, albumin köçürülməsi, diuretiklər), assitik fistullarda isə, bununla yanaşı, drenaj yerinin tikişlə bağlanması çox vaxt effekli olur. 


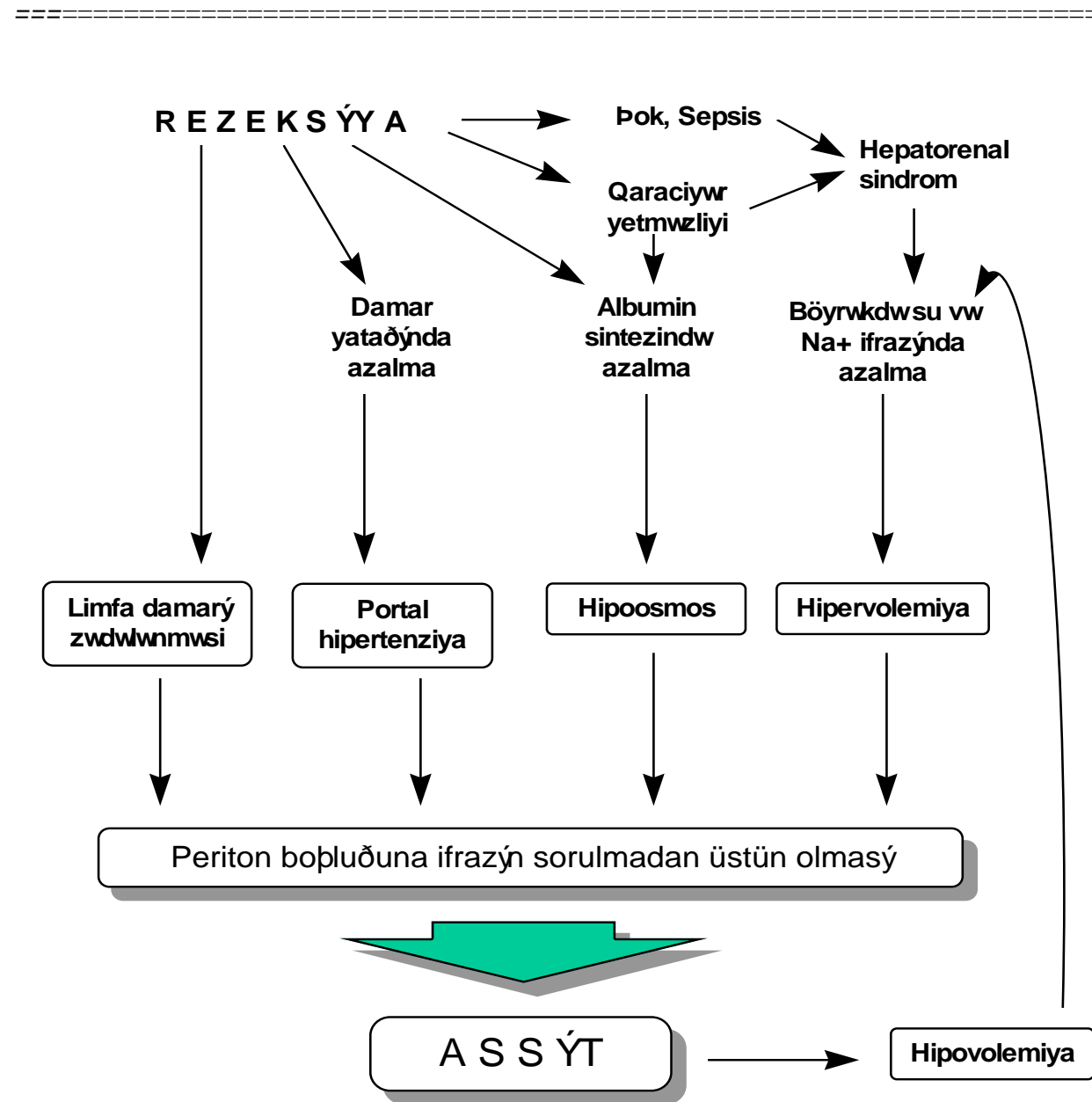

Şəkil 7.6.Postrezeksiyon assitin etiopatogenezi

$\mathrm{Bu}$ müalicəyə cavab verməyən refrakter assitlərdə parasentez (birdəfəlik və ya bir neçə gün dalba-dal) və uyğun miqdarda albumin və ya böyük molekullu (70000 Da) dekstran köçürülməsi lazım gəlir. Refrakter assitlərdə qapı və qaraciyər venalarında tromboz da nəzərdən qaçmamalıdır (Şəkil 7.7.). 

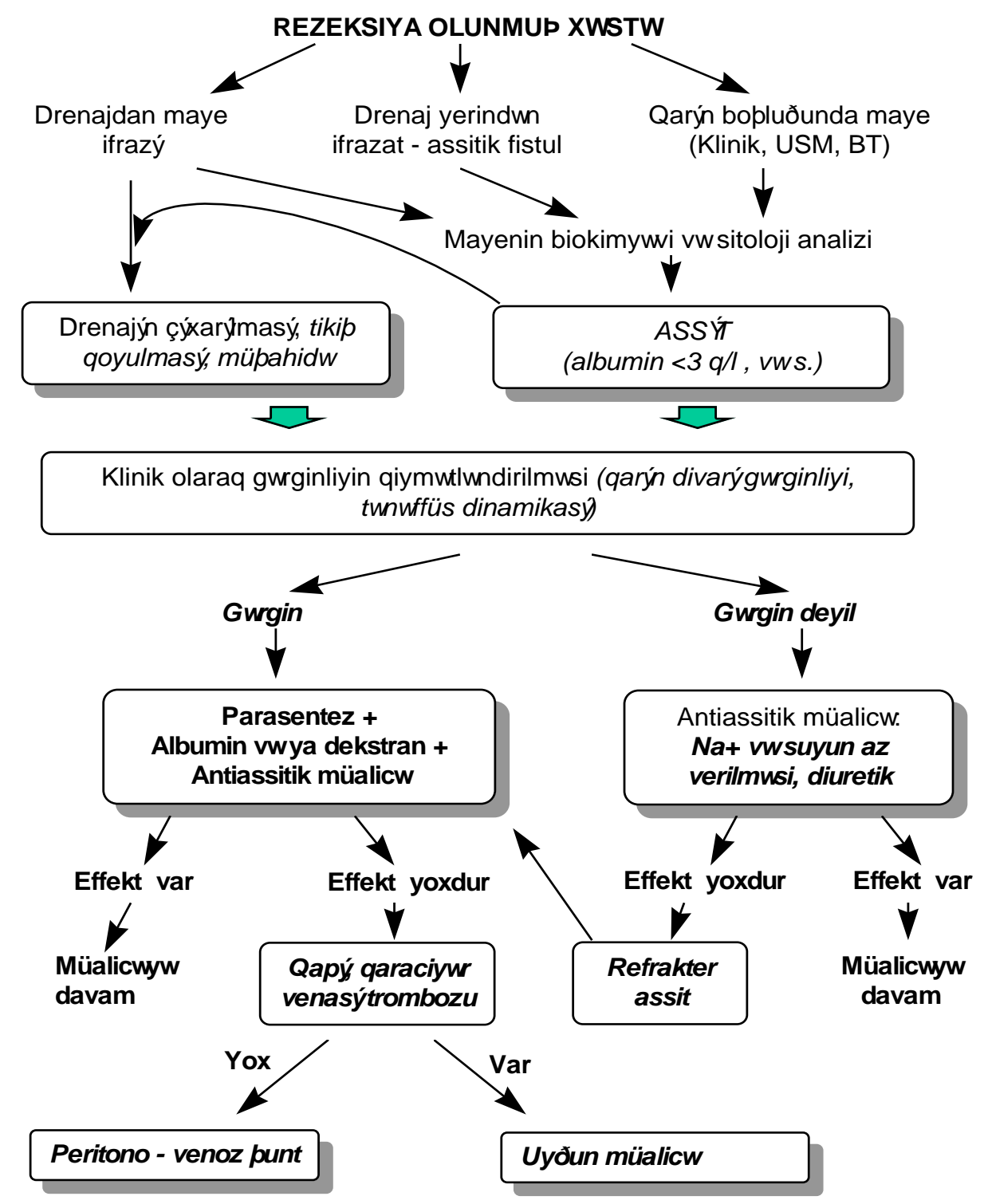

Şəkil 7.7.Postrezeksiyon assitin müalicə taktikası 


\section{ÖD FISTULLARI}

Öd fistulları kəsilmiş öd yollarından qarın boşluğuna ödün sızması nəticəsində ortaya çıxan ağırlaşmadır. Bu iki əsas səbəblə əlaqədar baş verə bilir (Şəkil 7.8.) . Birincisi, rezeksiya vaxtı kəsilmiş öd yollarının yetərsiz bağlanması və ya qoyulmuş liqaturanın çıxması. Bu zaman öd yollarından qarın boşluğuna öd sızır. Öd sızması ilk günlər daha çox olur, çünki, ilk günlərdəki bağırsaq atoniyası və ya Oddi sfinktorundakı spazmla əlaqədar öd yollarında təzyiq periton daxilindəki təzyiqdən yüksək olur. Atoniya və spazm aradan qalxdıqdan sonra öd sızması azalır. Defekt kiçik olduğu hallarda, fistul xətti üzrə inkişaf edən birləşdirici toxuma bu fistulların spontan olaraq bağlanmasına şərait yaradır.

Ikinci qrup səbəblərə öd yollarını mexanik olaraq tutan, yüksək təzyiq yaradan və öd sızmasını törədən amillər aid edilir. Qaraciyərin qalan hissəsində pay, seqment, sektor axacaqlarının bağlanması, qalan qaraciyərin ayaqcığının burulması və ya qatlanması, bə’zən də daşlarla əlaqədar öd yolları tıxana bilir. Anatomik rezeksiyalarda VI və VII seqmentlərin öd yollarının bağlanması ehtimalı daha yüksəkdir. Çünki, VI və VII seqmentlərin öd axacağı sağ medial sektorun portal ayaqcığını yuxarıdan qarmaq şəkilində dolanır (Hjortsjo qarmağı). V və VIII seqmentlər çıxarılarkən (soltərəfli genişləndirilmiş hemihepatektomiyalar, seqmentektomiyalar) bu axacaq asanlıqla bağlana bilir.

Öd fistulu baş verdikdə sarılıq, drenajdan axıntının artması və ödlü olması müşahidə edilir. Mexaniki səbəblər olmadığı hallarda drenajdan ilk 35 gün ərzində artan ödlü axıntı, 6-7-ci günlərdə azalmağa başlayır və adətən 10-14-cü günlərdə kəsilir. Mexaniki səbəblər olduqda isə, öd fistulundan axıntı daha uzun müddət davam edir və zədələn qaraciyər hissəsi atrofiya olana qədər müşahidə edilə bilir. Ona görə də, fistuldan ifrazatın azalmayaraq 14-gündən çox davam etdiyi hallarda mexaniki səbəblər araşdırılmalıdır. 
REZEKS ÝY A

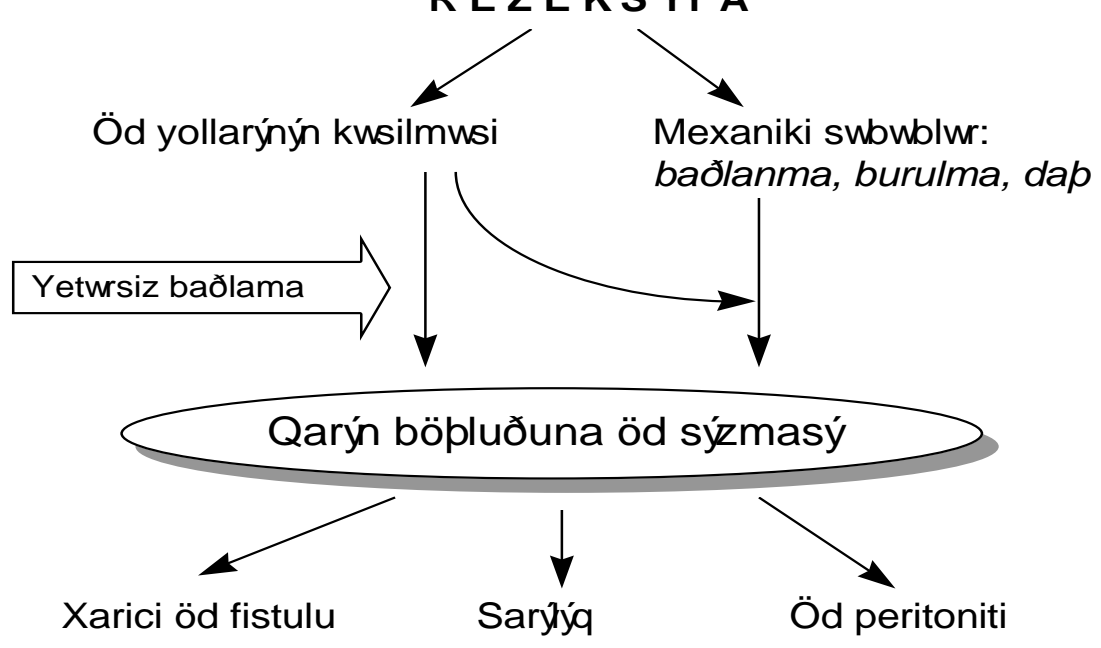

\section{Şəkil 7.8. Öd fitullarının etiopatogenezi}

Drenaj ifrazatında bilirubin miqdarının plazmadan çox olması, ifrazatda öd turşularının tapılması, bu ifrazatın öd yollarından olduğunu göstərən vacib əlamətdir. Fistuloqrafiya, retroqrad xolangioqrafiya, radioizotop müayinələri maneənin və ya zədələnmənin yerini dəqiqləşdirməyə imkan verir.

Öd fistullarının profilaktikası üçün anatomik rezeksiyaların aparılması, intrahepatik damar-axacaq elementlerinin görərək diqqətli bağlanması vacib şərtlərdəndir. Şüphəli hallarda əməliyyat sonunda "hava qabarcığı sınağı" aparılır. İncə iynə ilə xoledoxa hava vurulur və fizioloji məhlul içərisində yerləşdirilən kəsik səthi müşahidə edilir. Hava qabarcıqlarının çıxması bağlanmamış od yolunu göstərir. $\mathrm{Bu}$ yer tapılıb bağlanılır.

Mexanik səbəblər olmadığı hallarda öd fistulları adətən 10-14 gün ərzində müalicəyə ehtiyac olmasan spontan bağlanır. Mexaniki səbəblərə bağlı öd fistullarında adətən cərrahi müalicə lazım gəlir. Öd yolları bağlandığı hallarda biliodigestiv və ya fistulo-enterik anastomozlar qoyulur. Qaraciyər ayaqcığı burulması halında tə'cili laparotomiya və ya laparoskopiya lazım gəlir. Öd daşları laparatomiya və endoskopik retroqrad üsullarla çıxarılır (Şəkil 7.9.). 


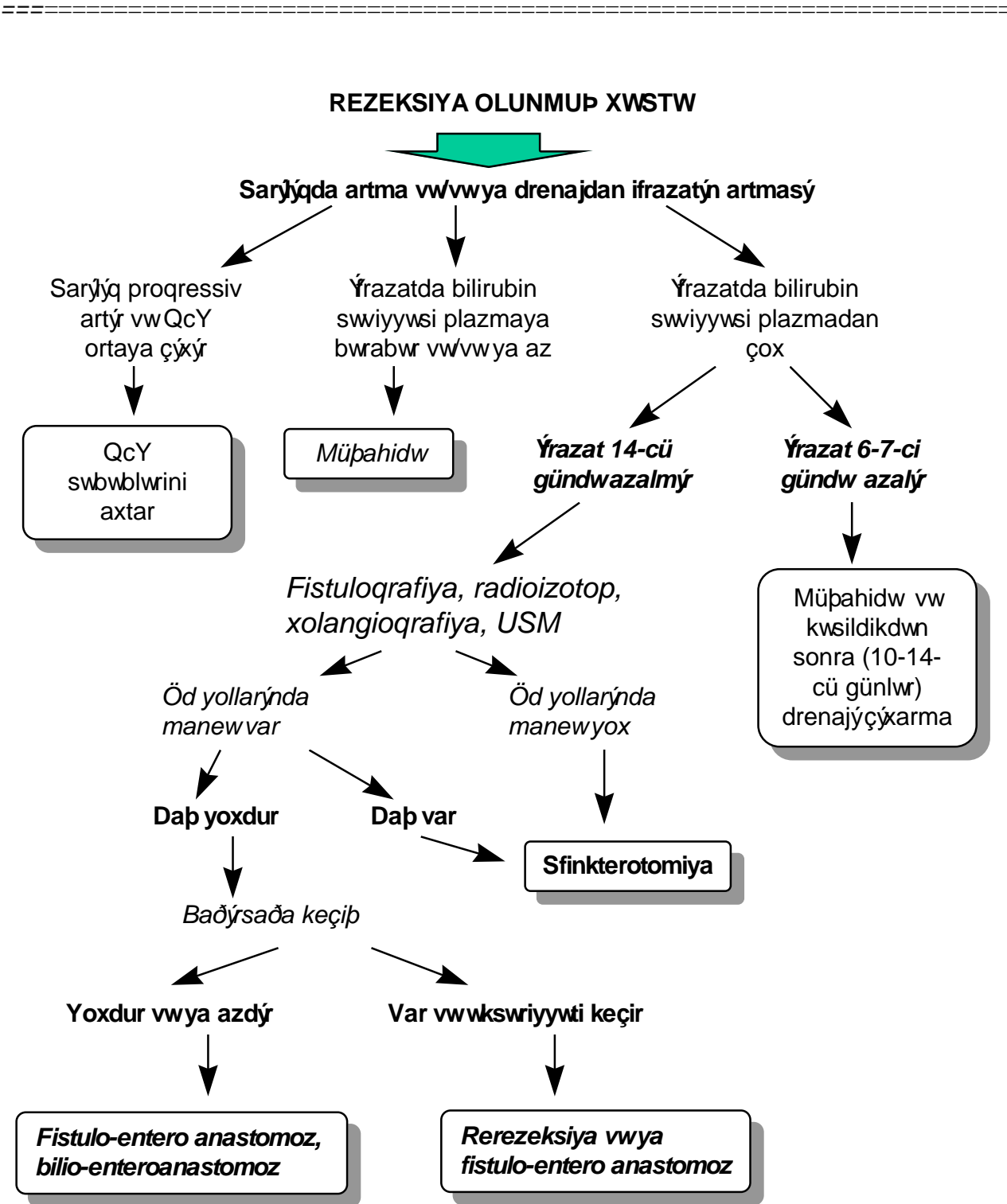

Şəkil 7.9. Öd fistullarında diaqnostika və müalicə taktikası

DAVAMLI SARILIQ 
Qaraciyər rezeksiyasından sonrakı ă̆ırlaşmalar

Davamlı sarılıq sirrotik xəstələrdə rezeksiyadan sonra 6-8\% hallarda rast gələn ağırlaşmadır. Ağırlaşmasız gedişdə bilirubin səviyyəsi rezeksiyadan sonra 3-4-cü günlərdə maksimal artır, 7-ci gündən başlayaraq 5 $\mathrm{mg} / \mathrm{dl}$-dən aşağı düşür, və 10-14-cü günlərdə əməliyyatönü səviyyələrə qayıdır. Davamlı sarılıqda bilirubin səviyyəsinin normal həddə düşməsi iki həftədən çox davam edir. Davamlı sarılığın baş vermə səbəbi kimi hissəvi hepatosellular yetməzlik ehtimal oluna bilər. Müalicəsi sirrozda olduğu kimidir və təbii öd turşularının zədələyici tə’sirini azaltmaq məqsədi ilə hidrofilliyi yüksək olan yarımsintetik öd turşuları da istifadə edilə bilər.

\section{MEXANIKI SARILIO}

Mexaniki sarılıq anatomik rezeksiyalarda çox az rast gələn ağırlaşmadır. Öd axacaqlarının səhvən bağlanması, daş, qalan qaraciyərin yerdəyişməsi nəticəsində öd axacaqlarının burulması, qatlanması və hemobiliya kimi mexaniki maneələr öd fistulu olmadığ 1 halda axacaq sistemində hipertenziya törədərək kəskin xolestazın ortaya çıxmasına səbəb olurlar (Şəkil 7.10).

Mexaniki sarılığın ağırlıq dərəcəsi, klinik gedişi və müalicə taktikası qalan qaraciyərdə xolestaza uğramış bölgənin ölçüsündən asılıdır. Qalan qaraciyərin $1 / 3$ hissəsindən azını tutan xolestazda sarılıq və diğər əlamətlər bariz ortaya çıxmır, bu hissə zamanla atrofiyaya uğrayır. Qalan qaraciyərin əksər hissəsində və ya tamamında öd axını pozulduğu hallarda isə, artan xolestaz əlamətləri və qaraciyər yetməzliyi baş verir. Maneə tezliklə ortadan qaldırılmazsa, xəstələrdə ă̆ır qaraciyər yetməzliyi meydana gəlir.

Hissəvi, xüsüsən də qalan qaraciyərin 1/3-dən azını tutan mexaniki sarılığın erkən diaqnostikası çətindir. Xəstələrdə regenerasiya ilə əlaqədar qələvi fosfataza (QF) səviyyəsində artma olduğu üçün, hissəvi xolestazların xarakteristik əlaməti olan "normal bilirubin səviyyəsinə baxmayaraq, QF də artama" diaqnostik əhəmiyyətini itirir. 
REZEKS ÝY A

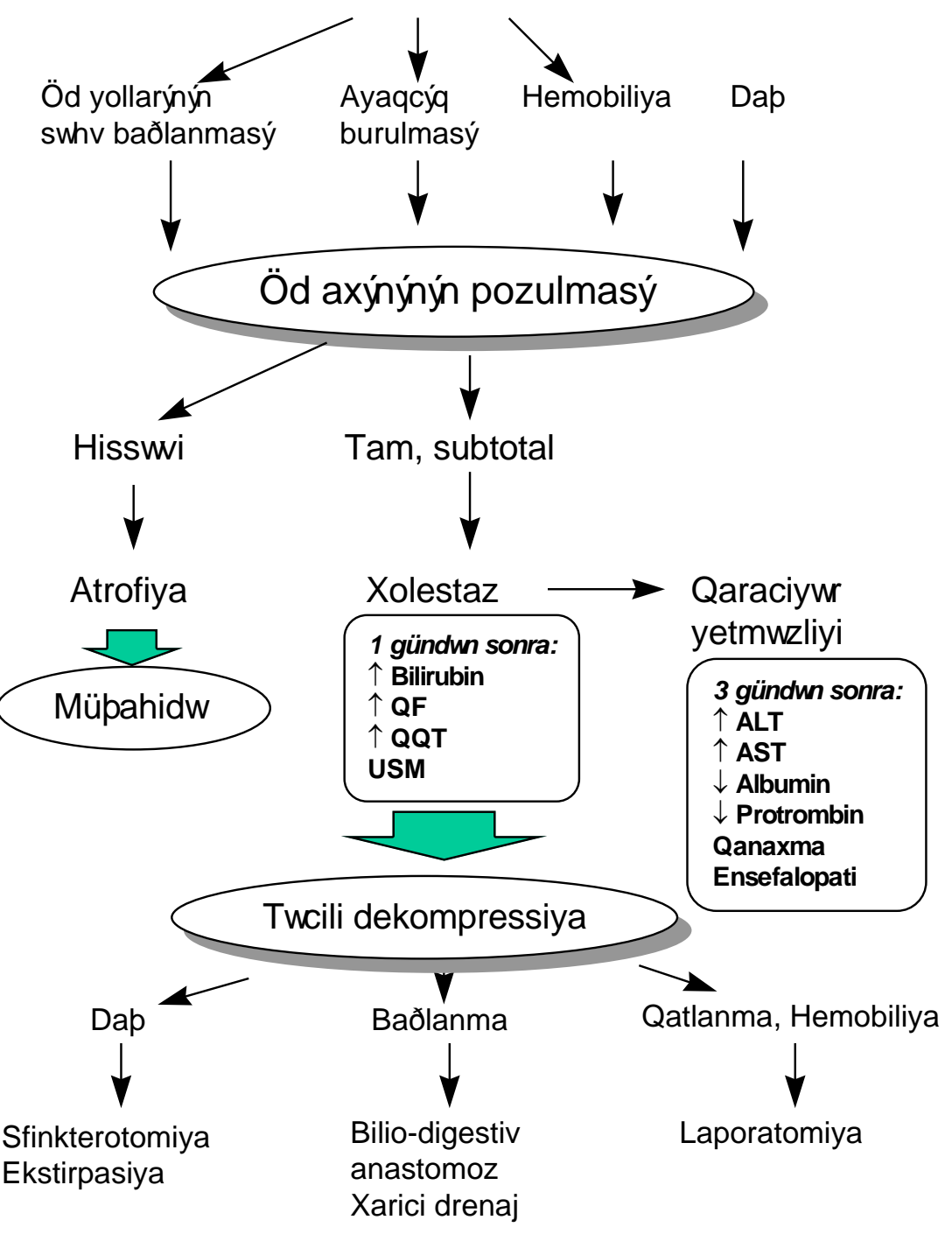

Şəkil 7.10. Postrzeksiyon mexaniki sarılığın etiopatogenezi, diaqnostikası vo müalicə taktikası 
Qaraciyər rezeksiyasından sonrakı ă̆ırlaşmalar

On güvənli üsul qalan qaraciyərin bir hissəsində axacaqlardakı genişlənmənin USM ilə müəyyən edilməsidir.

Total və ya subtotal mexaniki sarılıqda isə, əməliyyatdan sonrakı ilk günlərdən başlayaraq proqressivləşən xolestaz əlamətləri ortaya çıxır: sarılıq artır, bilirubin səviyyəsi artır, QF və QQT (qamma-qlütalil transferaza) səviyyələri yüksəlir. 4-5-ci günlərdən başlayaraq kəskin qaraciyər yetməzliyi simptomları görünür: ALT, AST səviyyələrində artma, hipoalbuminemiya, protrombin səviyyəsində azalma, qanaxmalar, ammonyak səviyyəsində artma, assit, ensefalopatiya. T1xanmadan 24 saat sonra edilən USM-də öd yollarında genişlənmə görünməsi, radioizotop, xolangioqrafiya üsulları diaqnozu dəqiqləşdirir.

Hissəvi, qalan qaraciyərin 1/3-dən azını tutan və klinik olaraq biruzə verməyən tıxanmalarda spesifik müalicə lazım gəlmir, müşahidə edilir. Tam, proqressivləşən tıxanmalar tə'cili müdaxilə- dekompressiya tələb edir, çünki, gecikmə qaraciyər yetməzliyinin inkişafına təkan verə bilər. Daş ilə əlaqədar tıxanmalarda endoskopik sfinkterotomiya ilə daş ekstraksiyası faydalı ola bilər. Qaraciyər ayaqcı̆̆ının qatlanması və ya burulmasında tə'cili laparptomiya və ya laparoskopiya lazımdır, çünki, öd yolları ilə yanaşı qan damarlarında da tıxanma mövcuddur və qatlanmanın açılması lazımdır. Öd yollarının bağlanması halında bilio-digestiv anastomoz və ya xarici drenaj (deridənkeçən transhepatik, əməliyyatdaxili) qoymaq olar. Anastomoz, bağlanmış axacın proksimalı və ya kəsik səthindəki mağistral axacaqla bağırsaq arasında qoyulur. Xəstənin ümumi vəziyyəti ağır olan hallarda isə, xarici drenaja üstünlük verilir.

\section{QARINDAXILII ABSESS}

Qarındaxili absess qaraciyər rezeksiyalardan sonra təxminən $8 \%$ (2-18\%) rast gələn ağırlaşma olub, başlıca olaraq nekrotik qaraciyər toxumasının qalması və qanın toplanması nəticəsində meydana çıxır (Şəkil 7.11). Xüsusən, sirrozlu xəstələrdə leykositlərin və limfositlərin funksional ehtiyatları zəiflədiyi üçün irinli ağırlaşmalara daha çox rast gəlinir. Oməliyyatdan 3-5 gün sonra yerli ağrı və septik əlamətlərlə özünü biruzə 
verir, görüntüləmə üsulları ilə diaqnozu dəqiqləşdirilir. Cərrahi və ya punksion yollarla drenaj edilməsi lazım gəlir (Şəkil 7.12) .

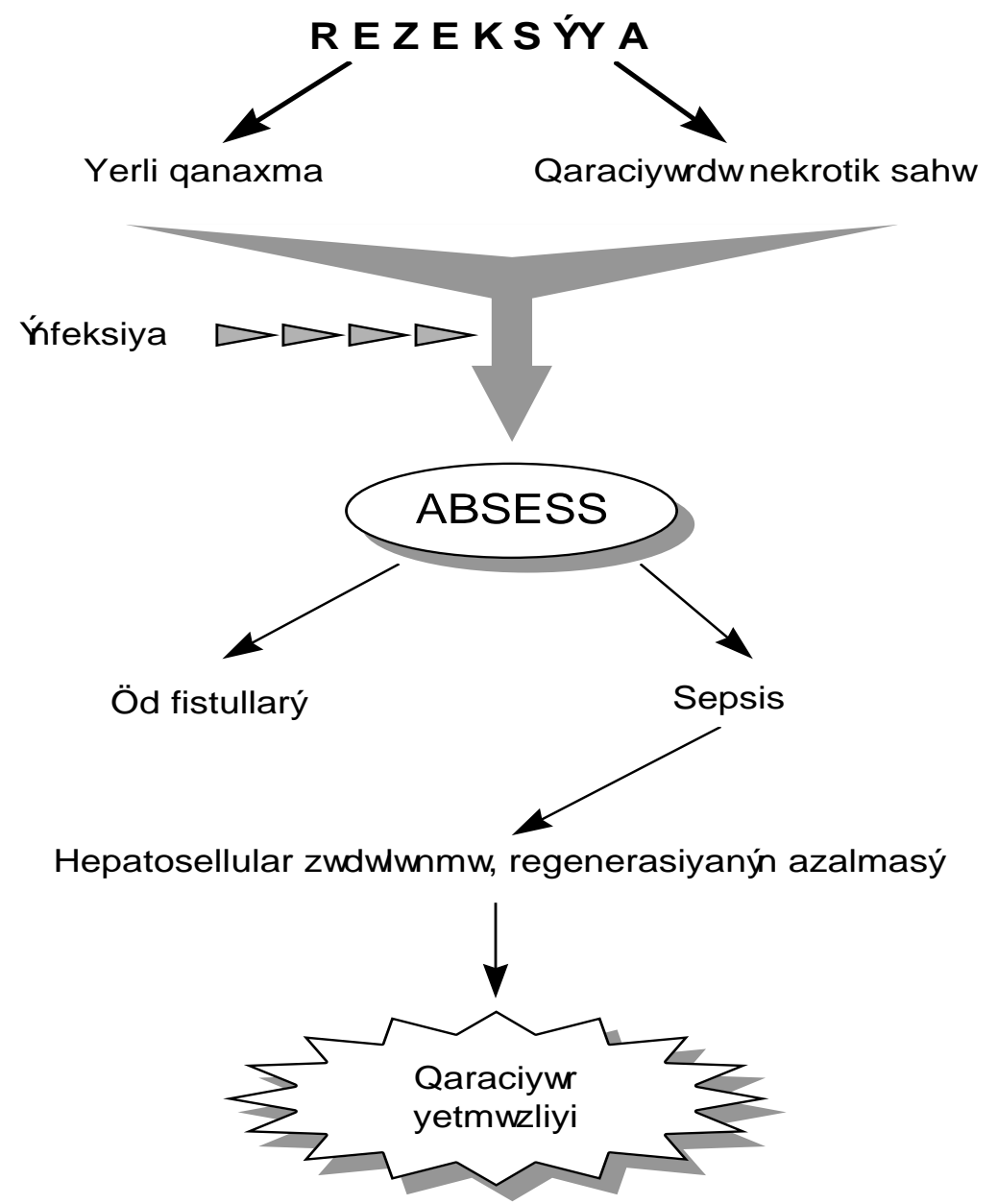

Şəkil 7.11. Postrezeksiyon absesin etiopatogeenezi 


\section{ABSES}
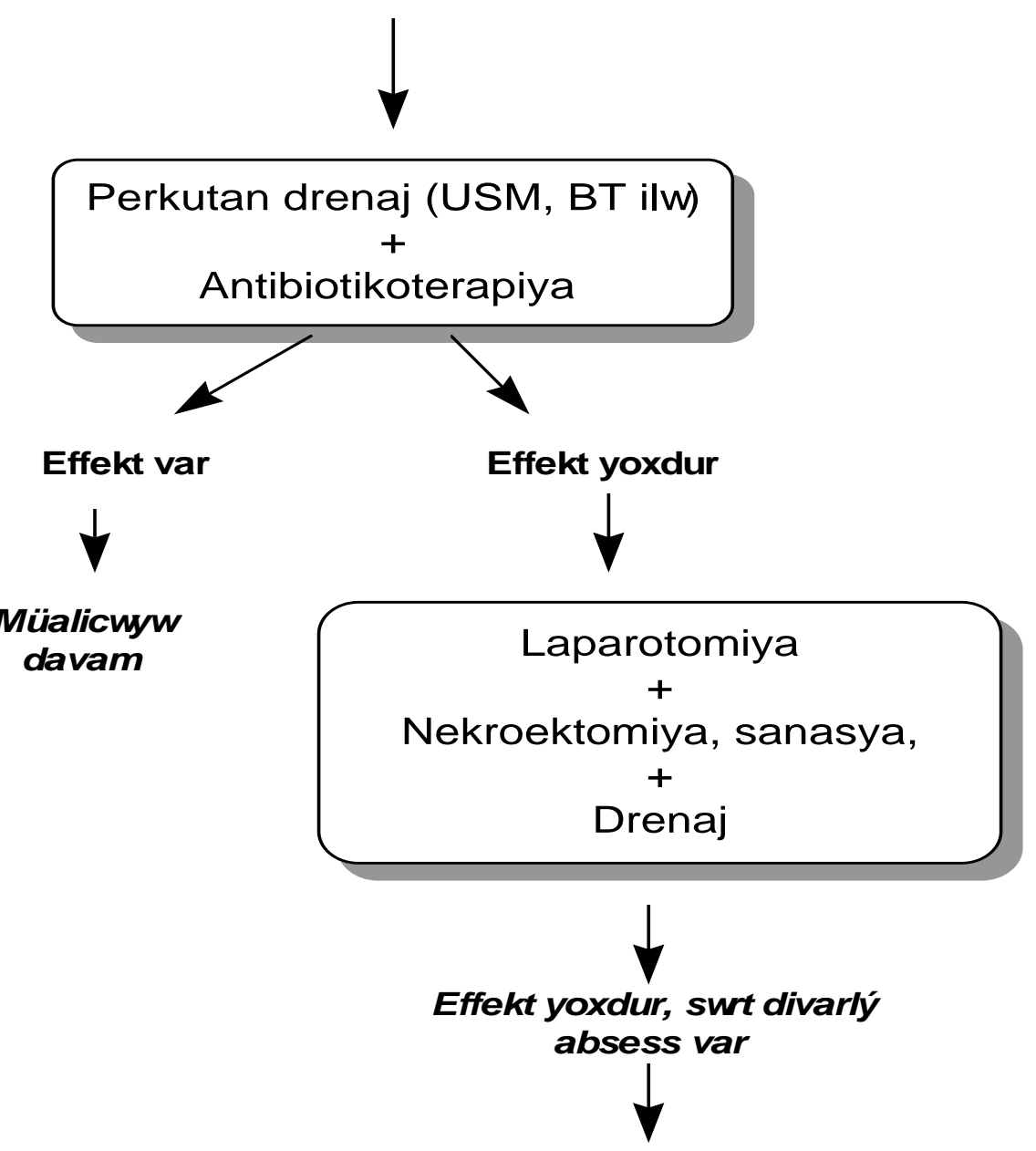

\section{REZEKSẂY A}

Şəkil 7.12. Postrezeksiyon absesin müalicəsi INTRABDOMINAL QANAXMA 
Intrabdominal qanaxma təhlükəli və tə'cili relaparatomiya tələb edən ağırlaşma olub, əməliyyat texnikasından asılı olaraq 2-20\% hallarda rast gəlinir. Osas səbəbi damardan liqaturanın qaçması və kapillyar qanaxmadır. Kapillyar qanaxmanın səbəbləri əvvəlki bölümdə verilmişdir. Qanköçürmə ilə korreksiya olunmayan $(500 \mathrm{ml}$ qan köçürülməsinə baxmayaraq, hematokriti 3 vahiddən az artması, 24 saatda 1500 ml-dən çox qan köçürülməsi) kəskin anemiya, drenajdan qangəlmə (bu hər zaman olmaya bilər) ilə özünü biruzə verir və ultrasəs müayinəsində qarında maye və qan laxtaları görünə bilir. Müalicəsi relaparatomiya və lokal hemostaz tədbirləridir.

\section{MӘ'DӘ-BAĞIRSAQ QANAXMALARI}

Postrezeksiyon qastrointestinal qanaxmalar başlıca olaraq iki səbəbdən baş verə bilir: qida borusunun varikoz genişlənmiş venalarından, xronik və ya stress xoralarından.

Varikoz qanaxmalar adətən portal hipertenziyası və III-IV dərəcəli varikoz genişlənmiş venalar $1^{1}$ olan xəstələrdə aparılan rezeksiyalardan sonra baş verir. Rezeksiya mövcud hipertenziyanı artırır və varikoz venaların partlamasına şərait yaradır. "Sirroz $\rightarrow$ Portal hipertenziya + Rezeksiya $\rightarrow$ Hipertenziyada yüksəlmə $\rightarrow$ Varikoz qanaxma" patogenetik zəncirini daha aydın başa düşülməsi üçün portal hemodinamikaya q1sa nəzər salmaq lazımdir.

Portal təzyiq dedikdə, qapı venasındakı qanın damar divarına etdiyi təzyiq nəzərdə tutulur və bu təzyiq qanın splanxik venalardan qaraciyərə və aşağı boş venaya axmasını tə'min edən əsas qüvvədir. Normada qapı venası ila boş vena arasindakı tozyiqlar farqi $5 \mathrm{~mm} \mathrm{Hg}$ st. təşkil edir. Bu farqin $8 \mathrm{~mm}$ Hg st.-dan çox olması portal hipertenziya kimi qabul olunur. Tozyiqlar farqi

${ }^{1}$ I daracada varikoz qida borusunun bir divarinda olur, II daracada varikoz venlar iki divarda olur, ancaq birloşmirlar, III daracada divarlarda birlaşmiş, dastaşakilli varislar görünür, IV daracada varislarin üzarində qırmızı rangli bölgalor müşahida edilir ki, bu da divarın naziklaşdiyini vo qanaxma ehtimalının yüksək olduğunu göstarir. 
$12 \mathrm{~mm} \mathrm{Hg}$ st.-dan yüksək olduqda iso, varikoz qanaxma riski yaranır. Hidrodinamikanın üç qanunu hemodinamikanın diğər bölgələri kimi, portal hemodinamikaya da təxmini olaraq şamil edilə bilər.

Om qanununa (1) görə damardan axan qanın miqdarı (Q) təzyiqlə (P) düz, müqavimətlə $(\mathrm{R})$ tərs mütənasibdir. Buradan, təzyiqin axan qanın miqdar1 və müqavimətlə düz mütanasib olduğu görünür (2):
(1) $\mathrm{Q}=\mathrm{P} / \mathrm{R}$
(2) $P=Q x R$

Pauzel qanununa (3) görə damarda müqavimət mayenin özüllülüyü (n) və damarın uzunluğu (L) ilə düz, damar radiusunun ( r ) dördüncü dərəcəsi ilə tərs mütənasibdir:

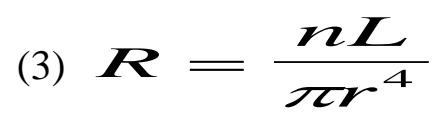

Laplas qanununa (4) görə isə, damar divarının gərilmə (G) elastiki qüvvəsi transmural təzyiq $(\mathrm{P})$ və damar radiusu ilə düz, divar qalınlığı (d) ilə tərs mütənasibdir. Yə’ni, damarın radiusu nə qədər böyük və divarı nə qədər incə olarsa, gərilmə o qədər çox olar və partlama imkanı o qədər yüksələr.

$$
\text { (4) } G=\frac{\operatorname{Pr}}{d}
$$

Om, Pauzel və Laplas qanunlarının portal hemodinamikaya tətbiqindən iki mühüm notica çıxır.

Birincisi, qanın özüllüyü və damar uzunluğu sabit götürülərsə, portal sistemdə təzyiq iki faktordan asılıdır: damarların radiusu və sisetmə galən qanin miqdarl.

$$
P \approx K \frac{Q}{r^{4}}
$$


Ona görə də, damar radiusunun azalması və gələn qanın miqdarının artması təzyiqi artıran amillərdir. Mütənasiblik radiusun dördüncü dərəcəsi ilə oldğu üçün radiusun azacıq kiçilməsi müqavimət və təzyiqin böyük dərəcədə artmasina səbəb olur.

Qaraciyərdə sinusoidlarin ümumi miqdar va kapillyar damar tonusu müqaviməti, təzyiqi müəyyən edən mühüm amillərdir. Qaraciyərdə portal qan axınına qarşı müqaviməti artıran mexanizmlər damar yatağının miqdarını azaldaraq, damar mənfəzini orqanik və ya spastik kiçildərək və qan axınını əngəlləyərək təzyiqin artmasına səbəb olurlar. Portal trombozda, aşağ 1 boş vena trombozunda (Baddi-Kiari sindromu), şişlərin tezyiqi və invaziyası nəicəsində damarlarda üzvi tıxanmalar meydana gəlir. Rezeksiya qaraciyərdə damar yatağının azalmasına səbəb olaraq müqaviməti artırır. Sirrozda fibrozla əlaqədar damar yatağında azalma, spastik mənşəli damar daralması və arteriovenoz şuntlar portal təzyiqi artırırlar. Kapillyar və kiçik damar tonusunun tənzimində endoteldən ifraz olunan vazokonstruktor (endotelin) və vazodilatatorlar (nitrik oksid və prostaqlandinlər) mühüm rol oynayır. Bu lokal tənzimləyicilər endotel ətrafındakı saya əzələlərə tə'sir göstərərək damarın mənfəzini dəyişdirirlər. Qaraciyər sinusoidlərində bu funksiyanı perisinusoidal bölgədə yerləşən, intrasellülar çıxıntıları olan, lipositlər adlanan hüceyrələr yerinə yetirir. Lipositlərin miofibroblastlar (çapık toxuması hüceyrələri) kimi, kollagen sintezinə və yı̆̆ılma qabiliyyətinə malikdirlər. Sirrozda endoteldən nitrik oksidin sintezinin azaldığ 1 və lipositlərin gövşəməməsi ilə əlaqədar sinusoidlərin daraldı̆̆ təxmin edilir. Bundan başqa lipositlərin törətdiyi fibrotik toxumanın damar yatağını azaltması da portal təzyiqin artmasına yol açır.

Portal təzyiqi artıran $i k i n c i$ vacib faktor splanxik sistemə gələn qanın miqdarıdır. Daxili orqanlardakı arteriolalarda baş verən vazodilatasiya və arteriyal sistemdəki təzyiq sistemə gələn qanın artmasında mühüm rol oynayır. Glükaqon, prostaqlandin və nitrik oksidlə yanaşı toxumaların funksiyonal aktivliyinə bağlı olaraq artan lokal metabolitlər də, splanxik damarlarda vazodilatasiya törədərək qangəlimini və portal təzyiqin artmasına səbəb olurlar. Ona görə də, portal hipertenziyada və varikoz qanaxmaların profilaktikasında damardaraldıcılarla (vazopressin, $\beta$-adrenoblokatorlar) 
Qaraciyər rezeksiyasından sonrakı ă̆ırlaşmalar

yanaşı, qastrointestinal sistemin funksional yükünün azaldılmasına da əhəmiyyət verilir.

Hemodinamik qanunların portal hemodinamikaya tətbiqindən ortaya çıxan ikinci noticə isə, varikoz qanaxmanın mexanizmidir. Varikoz qanaxma genişlənmiş damarların nazilmiş divarlarında baş verən gərilmə və cırılma nəticəsində meydana gəlir. Laplas qanununa görə təzyiqin artması, radiusun artması və divarın qalınlığının azalması ilə gərilmə qüvvəsi də artır. Ona görə də, portal təzyiqin artmas ilk növbədə böyük və nazik divarlı (III və IV dərəcə) varislərdən qanaxmaya səbəb olur. Bu səbəblə əlaqədar varikoz qanaxmanın profilaktikasında təzyiqin azaldılması ilə yanaşı varislərin kiçildilməsi (liqasya, skleroterapiya) də əhəmiyyətlidir.

Rezeksiya bir tərəfdən splanxik vazodilatasya törədib gələn qanın miqdarını artıraraq, digər tərəfdən damar yatağını azaldıb portal qan axınına qarşı müqaviməti artıraraq, portal təzyiqi artırır. $\mathrm{Bu}$, varikoz venlərin yükünü artıraraq, onların daha da genişlənməsinə səbəb olur. İzafi genişlənmə isə, partlama törədərək qanaxma ilə nəticələnir. Mədə-bağırsaq mənfəzinə axan qan parçalanaraq toksik maddələr əmələ gətirir. Toksiki qan məhsulları isə, qaraciyərə zədələyici tə'sir göstərərək qaraciyər yetməzliyi törədə bilirlər (Şəkil 7.13). Ona görə də, mə'də-bağırsaq qanaxmalarında qanaxmanı dayandırmaq və qanı əvəzetmə tədbirləri ilə yanaşı qastrointestinal sistemin qandan təmizlənməsi də vacibdir. 


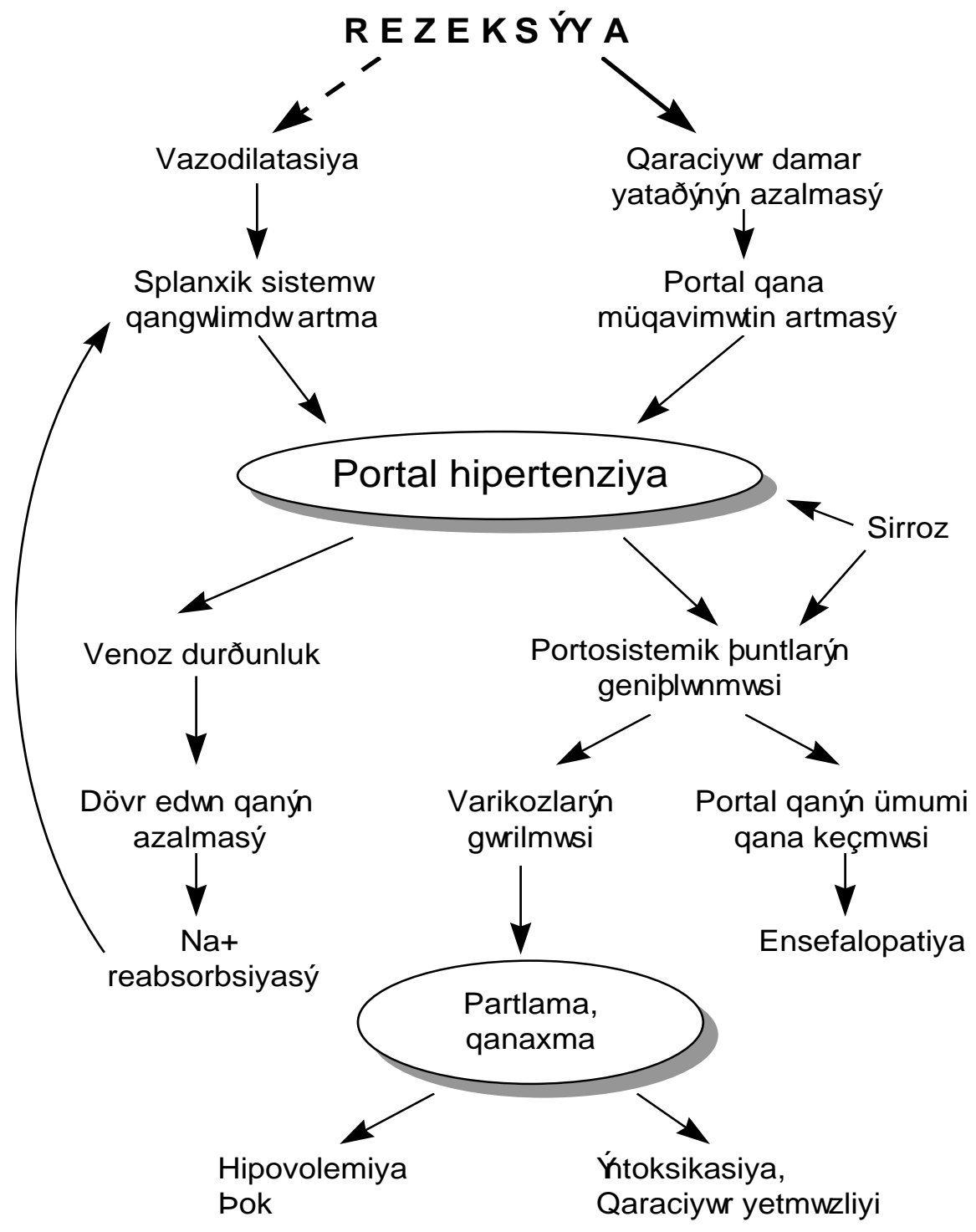

Şəkil 7.12. Postrezeksiyon varikoz qanaxmanın etiopatogenzi 
Qaraciyər rezeksiyasından sonrakı ă̆ırlaşmalar

Koskin vo kronik xoralalardan baş verən qanaxmalar son illər az rast gəlməyə başlamışdır ki, bu da histamin-2 reseptor blokatorlarının və ya hidrogen körüyü blokatorlarının profilaktik və müalicə məqsədiylə istifadəsinə bağlıdır.

Streslə əlaqədar əmələ gələn kəskin xoraların inkişafında iki amil mühüm rol oynayır (Şəkil 7.14). Birincisi, mikrosirkulyasiyanın pozulması nəticəsində mə'dənin selikli qişasının işemiyası, nekrozu və selik ifrazının azalması ki, bunlar selikli qişanın turşuya müqavimətini ciddi şəkildə azaldır. Íkincisi isə, mə’dədə davam edən sekresiya ifrazıdır ki, bu da selikli qişanın müdafiəsiz bölgələrinin əriməsinə, eroziya və xoralaşmasına təkan verir. Qaraciyər rezeksiyası bir tərəfdən böyük stres reaksiyası törədərək splanxik sistemdə vazokonstruksiyaya səbəb olur. Stres vaxtı splanxik sistemdə və dəridə baş verən vazospazm hemodinamikanı qorumağa yönələn ilk müdafiə reaksiyalarından biridir. Kəskin xoraların baş vermə ehtimalı stresin ağırlığı və müdddəti ilə mütənasib olaraq artır. Xüsusən, şok və ağır hipovolemiyalarda xoraların əmələ gəlmə ehtimalı artır. Diğər tərəfdən portal hemodinamikada baş verən dəyişikliklər və qaraciyər yetməzliyi venoz axında və koaqulyasiyada pozulmalar törədərək selikli qişanın qan dövranında ciddi azalmalra səbəb olurlar. Ona görə də, ağır travmalarda, böyük əməliyyatlarda olduğu kimi, qaraciyər rezeksiyalarında da stres qanaxmalarının profilaktikası vacibdir.

Qastrointestinal qanaxmalar özünü yerli və ümumi əlamətlərlə biruzə verir. Mə’də zondundan qan gəlməsi, qanq usma və melena qanaxmanın mütləq əlamətləridir. Bu əlamətlərlə yanaşı ümumi əlamətlərin də (hipovolemiya və hipokonsentrasiya) müşahidə edilməsi qanaxmanın ciddi və böyük olduğunu göstərməkdədir.

Mə'də-bağırsaq qanaxmalarının diqnostikasında endoskopik müayinə mühüm yer tutur. Endoskopiya qanaxmanın yerini, səbəbini, davam edib-etmədiyini müəyyən etməyə, bir çox hallarda isə, müalicə etməyə imkan verir (Şəkil 7.15). 


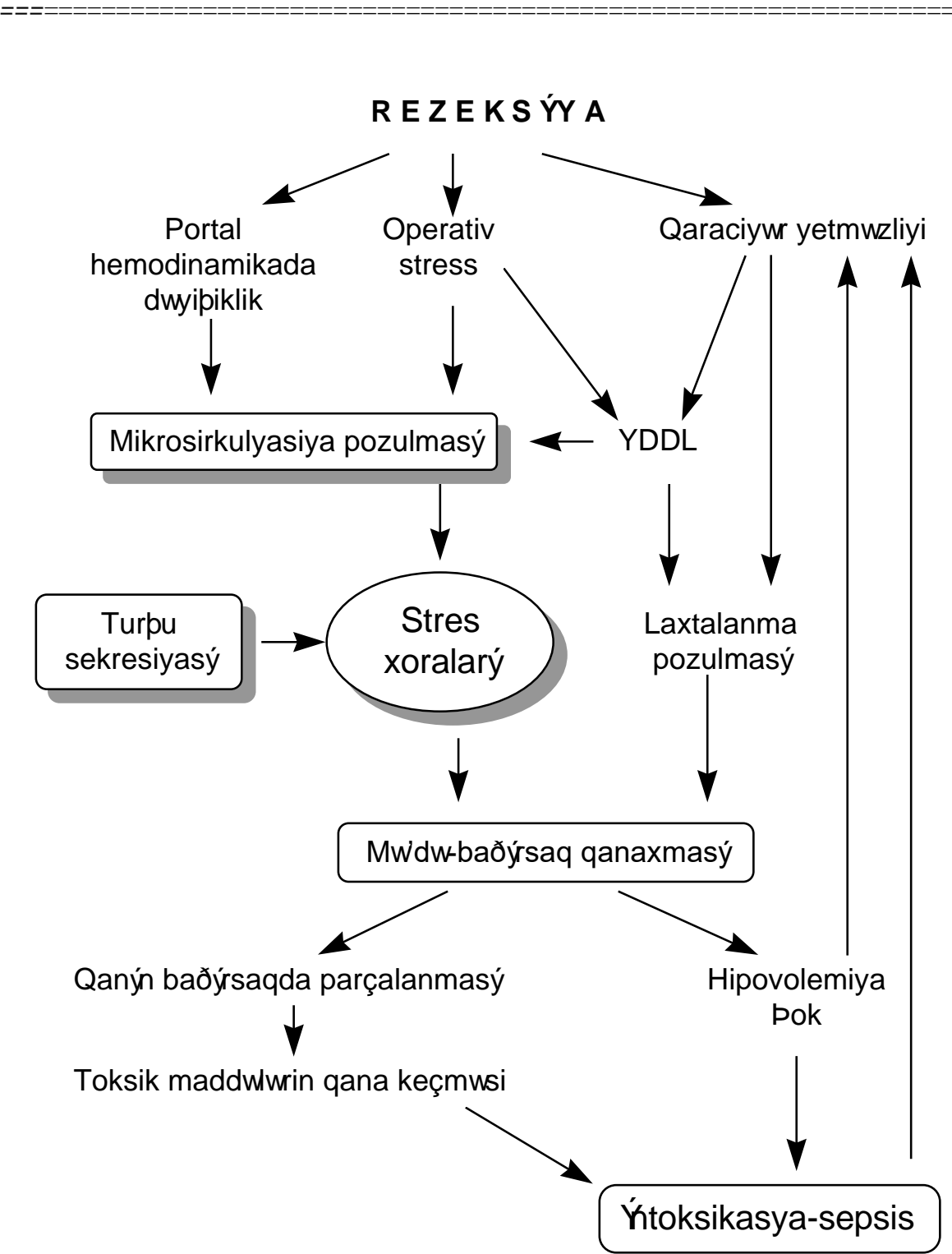

Şəkil 7.14. Stress xoralarının etiopatogenezi 
Qaraciyər rezeksiyasından sonrakı ă̆ırlaşmalar

Varikoz qanaxmanın profilaktikası üçün portal hipertenziya əlamətləri olan xəstələr, xüsusən, sirrozlu xəstələr əməliyyatdan əvvəl endoskopik müayinə edilərək, varislərin varlığı, dərəcəsi müəyyən edilməlidir. Qanaxma riski yüksək olan, III və IV dərəcə varisli xəstələrə (qida borusunun bütün divarlarını tutan, dəstəşəkilli birloşmiş, üzərində qırmızı rangli bölgalor olan varislar) rezeksiyadan 3-4 həftə öncə varislərin liqasyası və ya skleroterapiyası aparılmalıdır. Endoskopik üsullar daha effektli olduğu üçün əvvəllər rezeksiya ilə birlikdə yerinə yetirilən müxtəlif cərrahi əməliyyatlar (qida borusunun kəsilib yenidən tikilməsi, devaskularizasiyası, portokaval, splenorenal şuntlar) hazırda nadir istifadə edilir.

Stress xoralarının və qanaxmalarının profilaktikası üçün hemodinamikanın sabit saxlanılması ilə yanaşı əməliyyat vaxtından başlamaq üzrə 3 gün ərzində xəstəyə $\mathrm{H}_{2}$-blokator Ulkran (Ranitidin) $40 \mathrm{mg} /$ gün dozada venadaxilinə verilir. Bu məqsədlə $\mathrm{H}+$ körüyü blokatoru Lansprozol da istifadə edilə bilər.

Müalicosi. Qanaxmanı dayandırmaq, axan qanı avoz etmək vo mə'do-bağırsaq sistemini qan və onun toksik parçalanma məhsullarından təmizləmək qastrointestinal qanaxmanın əsas müalicə prinsipləridir.

Endoskopik liqasya və/və ya skleroterapiya varikoz qanaxmaların müalicəsində ən effektiv üsul sayılır. Varikoz qanaxmaları dayandırmaq üçün çoxkanallı Blekmor balonunun, splanxik qangəlimi azaldan vazokonstriktorların (somatostatin anoloqu oktreoid, oksitossin analoqu vazopressin və ya glipressin) postrezeksiyon xəstələrdə istifadə edilməsi məsləhət görülmür. Çünki, balon qida borusunda yataq yaraları əmələ gətirə bilir, qanaxmanın təkrarlanma ehtimalı yüksəkdir, tənəffüsü pozur. Vazokonstriktorlar isə, qaraciyər regenerasiyasını azaldırlar (Şəkil 7.15).

Xora mənşəli qanaxmalarda hipovolemiya və laxtalanma pozulmalarının aradan qaldırılması ilə yanaşı, yerli və ümumi antiasidlər istifadə edilir. Bu məqsədlə mə’də soyuq antiasid məhlulları ilə yuyulur, venadaxilinə histaminoblokator və ya hidrogen körüyü blokatorları verilir. 


\section{REZEKSẂYA OLUNUP XWSTW \\ $\downarrow$}

Mwdwzondundan qan gwmw, qan qusma, melena, qanaxmanýn ümumi wamwtlwri<smiles>C1C2CC1C2</smiles>

Mwdw-baðýrsaq qanaxmasý

Ýfuziyon terapiya

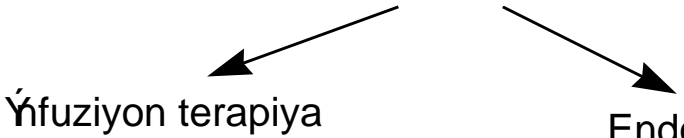

Qan köçürmw (wgwr $\mathrm{Ht}<25)$

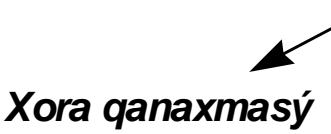

$\downarrow$

Mwdwnin yuyulmasý

$+$

Endoskopiya

Yerli antiasidlwr

Vena daxilinw

$\mathrm{H}_{2}$-blokatorlar (ranitidin) vwya

$H_{+}$körüyü blokatorlarý(lansprozol)

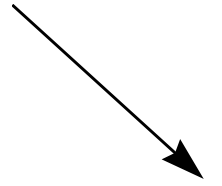

Varikoz qanaxma

$\downarrow$

Endoskopik liqasya, skleroterapiya

$+$

Mwdunin yuyulmasý

Ýnalw

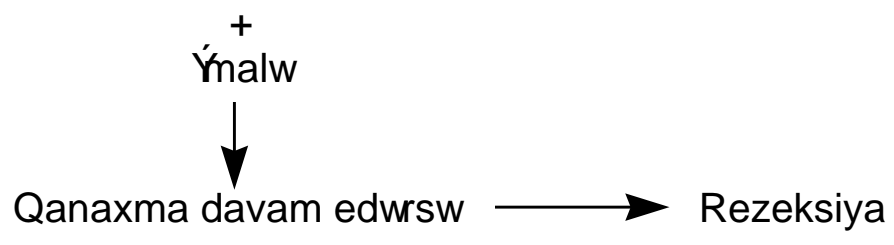

Şəkil 7.15. Mo'do-bağgrsaq qanaxmasında diaqnostika və müalicə taktikası 
$\mathrm{Bu}$ tədbirlər effektsiz olduqda və laxtalanma sistemində ciddi pozulma (YDDL, hiperfibrinoliz, hipokoaqulyasiya) yoxdursa, son müalicə kimi mə’də rezeksiyasına qərar verilir. Lakin, stress xoraları və qanaxmaları daha çox şok və laxtalanma pozulmalarına bağlı olduğu üçün turşuluğun rolu ikinci dərəcəlidir. Şok və laxtalanma pozulmalarının düzəldilməsi ağırlaşmanı aradan qaldıra bilir. Qanaxmanın davam etməsi adətən bu faktorların aradan qaldırılmaı̆̆ını göstərir və mə'də rezeksiyasına nadir hallarda ehtiyac qalır.

Axmış qanın həcmcə və tərkibcə əvəzedilməsi qanaxmanı dayandırma tədbirləri ilə birlikdə başladırlır və ümumi prinsiplərə görə aparilır.

Mə’də-bağırsaq mənfəzinə tökülmüş qanın təmizlənməsi xora və varikoz qanaxmalarda intoksikasyanın vo qaraciyər rezeksiysının profilaktikası üçün mühüm şərtdir. Xəstələrdə endoskopla, zondla mə’dəni yumaq, təmizləyici bağırsaq imalələri etmək lazımdır.

\section{QARACIYOR YETMOZLIYI}

Qaraciyər yetmozliyi $(Q c Y)$ rezeksiyalardan sonra, xüsusən, sirrotik qaraciyərlərdə aparılan böyük həcmli rezeksiyalardan sonra baş verən, müalicəsi çətin və həyatı təhlükəsi yüksək olan ağırlaşmadır. Bu ağırlaşma rezeksiyalardan sonra təxminən 12\% (3-75\%) hallarda rast gəlir, 80-90\% hallarda ölümlə nəticələnir və rezeksiyalardan sonrakı ölüm hallarının başlıca səbəbidir. Rezeksiyadan sonrakı qaraciyər yetməzliyinin inkişaf mexanizmi tam aydınlaşdırılmamışdır. Lakin, rezeksiyadan sonra qalan qaraciyərdə gedən reaktiv proseslərin pozulmasına xüsusi əhəmiyyət verilir. Mə'lumdur ki, rezeksiya nəticəsində qaraciyərin funksional hissəsinin azalması qalan qaraciyərə düşən funksional yükü artırır, bu isə, qalan qaraciyər parçasında bir biri ilə s1x əlaqəli olan üç əsas prosessin getməsinə təkan verir: funksiyaların müvəqqəti kompensasiyası, regenerasiya və zədələnmə. Normal halda qaraciyərin $60-70 \%$ çıxarıldıqda, ilk günlər müvəqqəti funksional yetməzlik baş versə də, qaraciyər regenerasiya edərək funksional və morfoloji cəhətdən bərpa olunur. Lakin, rezeksiya həcmi 75$80 \%$ dən çox olarsa qalan qaraciyər parçasında zədələnmə, tam funksional 
dekompensasiya baş verir, regenerasiya ciddi şəkildə azalır və ağır qaraciyər yetməzliyi baş verir. Ona görə də, 70-75\% qaraciyər rezeksiyalarında üst hədd sayılır. Qalan qaraciyər üzərinə düşən funksional yükü artıran (sepsis, şok, qastrointestinal qanaxmalar), qaraciyərin funksional ehtiyatlarını azaldan (sirroz, hepatit kimi parenximatoz xəstəliklər) və ya əməliyyatdan sonra qaraciyəri zədələyən faktorlar (intraoperativ travma, mexaniki sarılıq, arterial və ya venoz trombozlar, sepsis, toksik dərmanlar) qalan qaraciyərin funksional dekompensasiyasına səbəb olurlar. İlk günlərdə hepatositlərdə aktiv mitoz prosesi getdiyi üçün onların funksiyaları zəifləyir. Ona görə də, bu dövrdə qaraciyərə düşən yükün azaldılması, heç olmasa artırılmaması vacibdir. Yə’ni, qalan qaraciyərin funksional ehtiyatları ilə rezeksiyadan sonra onun üzərinə düşən funksional yük arasındakı nisbət, qaraciyər yetməzliyinin baş verib-verməməsində həlledici rol oynayır.

İlk saatlardan başlayan regenerasiya, rezeksiyadan sonra meydana çıxan morfo-funksional yetməzliyin aradan qaldırılmasına yönəlmiş başlıca müdafiə prosesidir. Qaraciyərin yüksək regenerator imkanlarnın olmasına baxmayaraq, regenerasiyanı ləngidən faktorlar (portal diversiya, sirroz, hepatit, arterial və venoz tromboz, regenerasiyanı azaldan dərmanlar və s.) qalan qaraciyər parçasında bərpa proseslərini gecikdirərək yetməzliyin davam etməsinə və dərinləşməsinə səbəb olurlar.

Üçüncü proses olan zədələnmə prosesi mahiyyətcə iltihab1 və ya işemik xarakterli olub, qaraciyər rezeksiyasından sonrakı kompensasiya və regenerasiya proseslərini müşayət edən atributiv prosesdir. Rezeksiyadan sonra baş verən zədələnmənin operativ travma, endotoksin, Kupffer hüceyrələrinin aktivləşməsi, mikrosirkulyasiya dəyişikliyi ilə əlaqədar ortaya çıxdığı bildirilir. Ağırlaşmasız hallarda zədələnmə q1sa müddətli, klinik olaraq simptomsuz (bə'zi hallarda əməliyyatdan sonrak1 hərarət istisna olmaqla), laborator olaraq transaminazaların müvvəqqəti artması ilə özünü biruzə verir. 
Qaraciyər rezeksiyasından sonrakı ă̆ırlaşmalar

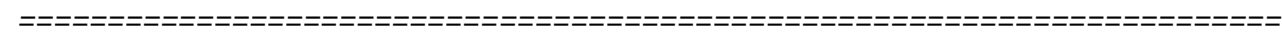

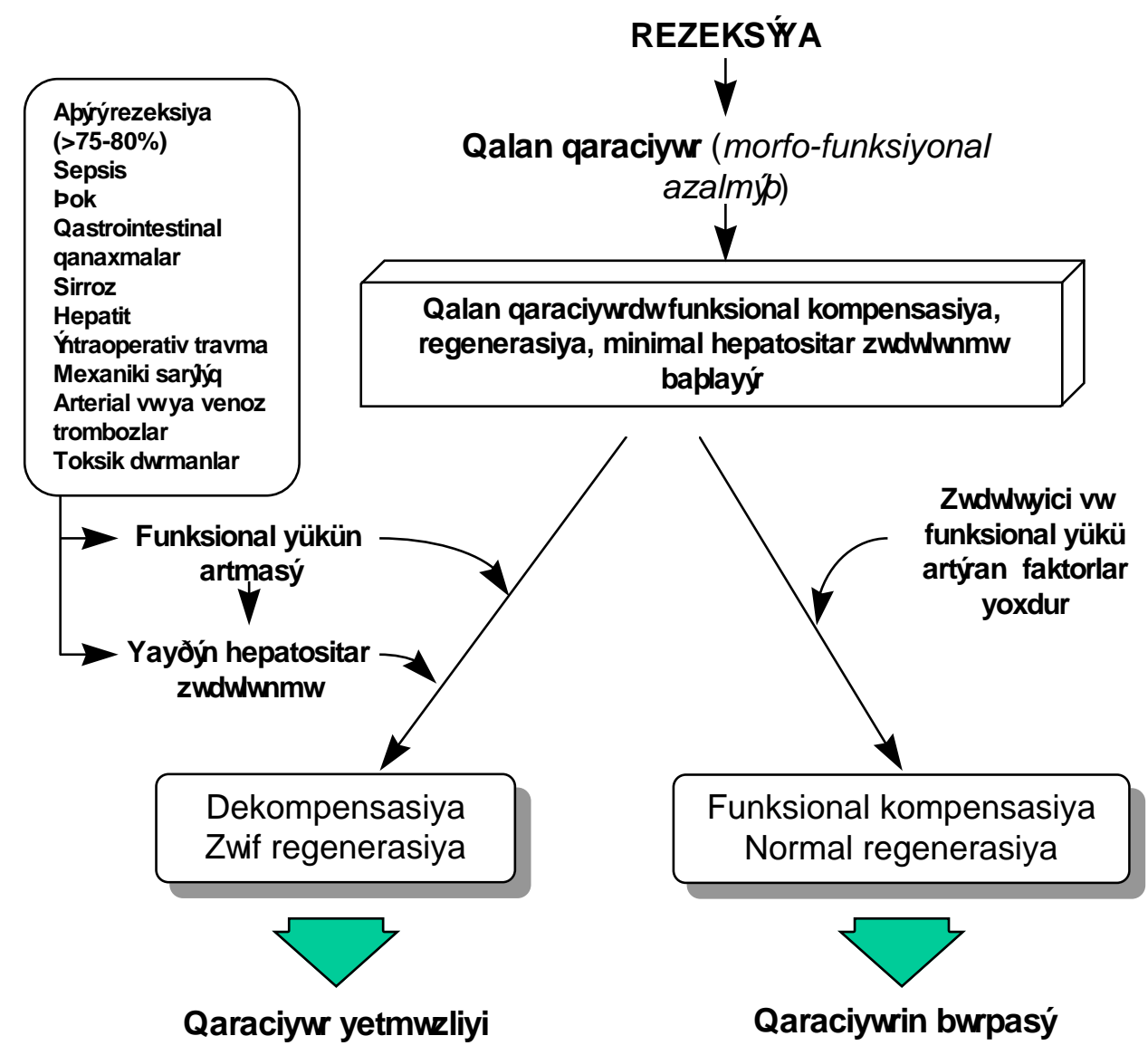

\section{Şəkil 7.16. Postrezeksiyon qaraciyər yetmozliyinin etiopatogenezi}

Lakin, sepsis-intoksikasiya, qan dövranı pozulması qastrointestinal qanaxma kimi, qaraciyərdə zədələnməni artıran faktorlar hepatositlərdə ciddi zədələnmə törədərək, bir tərəfdən kompensasiya prosesini, digər tərəfədən isə, regenerasiya prosesini pozaraq, qaraciyər yetməzliyinin baş verməsinə səbəb olurlar. Müasir dövrdə hepatositlərdə baş verən zədələnmədə Kupffer hüceyrələrinin aktivləşməsinin, xüsusən də, özünütənzim mexanizmin pozulmasının mühüm rolu olduğu bildirilir. Sirrozda, xronik hepatitdə, 
regenerasiya presesi dövründə Kupffer hüceyrələrinin aktivliyinin artdığ 1 , endotoksin və diğər zədələyici faktorların tə'sirindən isə, özünütənzim prosesinin pozulduğu və hepatosit zədələnməsinnin baş verdiyi bildirilir. Hesab edilir ki, çox böyük həcmli (>80\%) rezeksiyalardan sonra baş verən qaraciyər yetməzliyinin əsasında hiperemik tipli qan dövranının pozulmasına və endotoksinin nisbi artıqlığ1 nəticəsində Kupffer hüceyrələrinin hiperaktivləşməsinə bağlı meydana gələn zədələnmə prosesi durur. Yə’ni, rezeksiyadan sonra qalan qaraciyər zədələnməyə çox həssasdır. Ona görə də, qalan qaraciyəri zədələnmələrdən qorumaq rezeksiyadan sonrakı qaraciyər yetməzliyinin profilaktika və müalicəsindəki ən vacib prinsiplərdən biridir.

Belalikla, rezeksiyadan sonrakl qaraciyər yetməzliyinin baş verməsində qalan qaraciyərin funksional ehtiyatının azlı̆̆ının, kompensasiya vo regenerasiya prosesslarini pozan va zadəlonməni artıran faktorlartn mühüm rolu vardır.

Klinikast vo diaqnostikast. Postrezeksiyon qaraciyər yetməzliyi səbəbindən asılı olaraq, çox kəskin (damar trombozunda, mexaniki sarılıqda, aşırı rezeksiyalarda) və kəskin şəkildə (parenxima xəstəliklərində, qastrointestinal qanaxmalarda, sepsisdə və s.) ortaya çıxır. Oksər funksiyalarda-sintetik, detoksikasiya, energetik, hemodinamik proseslərdə

Qaraciyər yetmzliyi əlamətləri

- ALT $\uparrow, \mathrm{AST} \uparrow, \mathrm{GGT} \uparrow(3$ gün > 1gün)

- Bilirubin $\uparrow$

- Ensefalopatiya

- Protrombin va diğər laxtalanma faktorları $\downarrow$

- Hemorragiya

- Albumin $\downarrow$ gedərək dərinləşən pozulma müşahidə edilir. Ensefalopatiya, sarılıq, assit, intoksikasiya, hepatositlərin zədələnmə göstəriciləri qaraciyər yetməzliyinin başlıca diaqnostik əlamətləridir.

Profilaktika vo müalicəsi. Qaraciyər yetməzliyinin profilaktikasında funksional ehtiyatlarının və rezektabelliyin əməliyyətönü dövrdə tə’yini, qalan qaraciyəri zədələyə bilən faktorların (sepsis, şok, qastrointestinal qanaxmalar, çoxlu qanköçürmə və s.) aradan qaldırılması mühüm yer tutur. Müalicəsi başlıca olaraq funksiyaların əvəzedilməsinə (albumin, qlükoza, laxtalanma faktorları köçürülməsi, süni və köməkci qaraciyər sistemləri) , hepatosit zədələnməsinin (kortikosteroidlər, 
antioksidantlar, membran fosfolipidləri və s.) və intoksikasiyanın (hemo-, plazmosorbsiyalar, plazmoferez, dalaqdan perfuziyalar, sepsisin müalicəsi, qastrointestinal qanaxmaların müalicəsi və s.) aradan qaldırılmasına yönəlir. Proqnozu qənaətbəxş deyil, aparılan müalicələrə baxmayaraq ölüm faizi 8090\%-ə qədər yüksəlir. On effektiv müalicəsi tə'cili qaraciyər köçürülməsidir.

\section{ӘDӘВIYYAT}

1. Baer-HU; Stain-SC; Guastella-T; Maddern-GJ; Blumgart-LH. Hepatic resection using a əater jet dissector.HPB-Surg. 1993; 6(3): 189-96; discussion 196-8

2. Belghiti-J; Di-Carlo-I; Sauvanet-A; Uribe-M; Fekete-F. A ten-year experience aith hepatic resection in 338 patients: evolutions in indications and of operative mortality. Eur-J-Surg. 1994 May; 160(5): 277-82

3. Bismuth H; Chiche L; Castaing D. Surgical treatment of hepatocellular carcinomas in noncirrhotic liver: experience aith 68 liver resections. :Đorld J Surg. 1995 Jan-Feb. 19(1). P 35-41.

4. Bick RL. Disseminated intravascular coagulation: objective criteria for diagnosis and management. In: Common Bleeding and clotting disorders. The Med. Clin North Am, 1994, 78(3): 511-544

5. Burdelski-M; Schutz-E; Nolte-Buchholtz-S; Armstrong-VӘ; Oellerich-M. Prognostic value of the monoethylglycinexylidide test in pediatric liver transplant candidates. Ther-Drug-Monit. 1996 Aug; 18(4): 378-82

6. Capussotti-L; Borgonovo-G; Bouzari-H; Smadja-C; Grange-D; Franco-D. Results of major hepatectomy for large primary liver cancer in patients aith cirrhosis. Br-J-Surg. 1994 Mar; 81(3): 427-31

7. Closset-J; Gelin-M; el-Nakadi I; Van-de-Stadt-J; Lambilliotte-JP. Results of surgical resection for hepatocellular carcinoma. Acta-Chir-Belg. 1993 May-Jun; 93(3): 98-101

8. Cohnert-TU; Rau-HG; Buttler-E; Hernandez-Richter-T; Sauter-G; Reuter-C; Schildberg-FO. Preoperative risk assessment of hepatic resection for malignant disease. Đorld-J-Surg. 1997 May; 21(4): 396-400; discussion 401 
9. Davison-AM. Hepatorenal failure. Nephrol-Dial-Transplant. 1996; 11 Suppl 8: 24-31

10. Enəezor-CJ. Sixty cases of primary hepatocellular carcinoma in one year. A preliminary appraisal. Int-Surg. 1992 Oct-Dec; 77(4): 277-9

11. Gertsch-P; Stipa-F; Ho-J; Yuen-ST; Luk-I; Lauder-IJ. Changes in hepatic portal resistance and in liver morphology during regeneration: in vitro study in rats. Eur-J-Surg. 1997 Apr; 163(4): 297-304

12. Gines P, Salo J, Gines A. Advances in the treatment of renal disfunction in cirrhosis. In: ArroyoV, Bosch J, Rodes J. Treatments in Hepatology. Masson, SA, Barcelone 1995, 73-80

13. al-Hadeedi-S; Choi-TK; Әong-J. Extended hepatectomy for hepatocellular carcinoma. Br-J-Surg. 1990 Nov; 77(11): 1247-50

14. Hashimoto-M; Sanjo-K. Functional capacity of the liver after təo-thirds partial hepatectomy in the rat. Surgery. 1997 Jun; 121(6): 690-7

15. Hu-RH; Lee-PH; Yu-SC; Dai-HC; Sheu-JC; Lai-MY; Hsu-HC; Chen-DS. Surgical resection for recurrent hepatocellular carcinoma: prognosis and analysis of risk factors. Surgery. 1996 Jul; 120(1): 23-9

16. Ikeda-Y; Kanematsu-T; Matsumata-T; Shimada-M; Yamagata-M; Sugimachi-K. Liver resection and intractable postoperative ascites. Hepatogastroenterology. 1993 Feb; 40(1): 14-6

17. Itoh K; Nakao A; Kishimoto Ә; Itoh T; Harada A; Nonami T; NakanoM; Takagi $\mathrm{H}$. Decreased production of active oxygen species by neutrophils in patients əith liver cirrhosis and hepatocellular carcinoma. Gastroenterol Jpn. 1993 Aug. 28(4). P 541-6.

18. Iəata-S; Egaəa-H; Higashiyama-H; Kagaəa-R; Shimahara-Y; Mori-K; Ozaəa-K. Impaired energy metabolism of lymphocytes in cirrhotics after hepatectomy. JSurg-Res. 1992 Feb; 52(2): 184-90

19. Jenkins-LT; Millikan-KӘ; Bines-SD; Staren-ED; Doolas-A. Hepatic resection for metastatic colorectal cancer. Am-Surg. 1997 Jul; 63(7): 605-10

20. Kim YI., K. Nakashima, Tada I., et al. Prolonged normothermic ishaemia of human cirrhotic liver during hepatectomy: a preliminary report. Br J Surg, 1993; 80: 1566-1570. 
21. Kise $\mathrm{Y}$, et al. Comparison betəeen thoracoabdominal and abdominal approaches in occurrence of pleural effusion after liver cancer surgery. Hepatogastroenterology. 1997 Sep-Oct;44(17):1397-400

22. Klein AS, Smith Gə. Diagnostic operations of the liver and techniques of hepatic resection. In: Shacklefors's Surgery of the Alimentary Tract, 1996 ed. Volume III: 578-599

23. Koperna $\mathrm{T}$, et al. Infections after liver resections in the elderly. Langenbecks Arch Chir. 1997;382(4):192-6.

24. Lai-EC; Fan-ST; Lo-CM; Chu-KM; Liu-CL; Oong-J. Hepatic resection for hepatocellular carcinoma. An audit of 343 patients. Ann-Surg. 1995 Mar; 221(3): 291-8

25. Lee-ӘM. Management of acute liver failure. Semin-Liver-Dis. 1996 Nov; 16(4): $369-78$

26. van-Leeuəen-PA; Hong-RӘ; Rounds-JD; Rodrick-ML; Oilmore-D. Hepatic failure and coma after liver resection is reversed by manipulation of gut contents: the role of endotoxin.Surgery. 1991 Aug; 110(2): 169-74; discussion $174-5$

27. Lo CM, et al. Biliary complications after hepatic resection: risk factors, management, and outcome. Arch Surg. 1998 Feb;133(2):156-61.

28. Matsumata-T; Kanematsu-T; Okudaira-Y; Sugimachi-K; Zaitsu-A; HirabayashiM. Postoperative mechanical ventilation preventing the occurrence of pleural effusion after hepatectomy. Surgery. 1987 Sep; 102(3): 493-7

29. Matsumata-T; Taketomi-A; Fujiəara-Y; Shimada-M; Takenaka-K; Sugimachi-K. Renal function after elective hepatic resection. Hepatogastroenterology. 1996 May-Jun; 43(9): 602-7

30. Makuuchi M. Surgical treatment of hepatocellular carcinoma. In: ArroyoV, Bosch J, Rodes J. Treatments in Hepatology. Masson, SA, Barcelone 1995, 341 352

31. Miyazaki M; Sugasaəa T; Itoh H. et al. Significance of aminopyrine breath test as a parameter of hepatic functional reserve in $40 \%$ partial hepatectomy of rats əith CCl4-induced liver injury. Res Exp Med (Berl). 1995. 195(2). P 69-75.

32. Nagasue-N; Yukaya-H; Ogaəa-Y; Sasaki-Y; Chang-YC; Niimi-K. Clinical experience əith 118 hepatic resections for hepatocellular carcinoma. Surgery. 1986 Jun; 99(6): 694-701 
33. Nagino M; Nimura Y; Hayakaəa N; Kamiya J; Kondo S; Miyachi M; Kanai M. Disseminated intravascular coagulation after liver resection:retrospective study in patients əith biliary tract carcinoma. Surgery. 1995 May. 117(5). P 5815.

34. Nagasue N; Uchida M; Kubota H; Hayashi T; Kohno H; Nakamura T. Cirrhotic livers can tolerate 30 minutes ischaemia at normal environmental temperature. Eur J Surg. 1995 Mar. 161(3). P 181-6.

35. Nagasue N; Kohno H; Chang YC; Taniura H; Yamanoi A; Uchida M; Kimoto T; Takemoto Y; Nakamura T; Yukaya H. Liver resection for hepatocellular carcinoma. Results of 229 consecutive patients during 11 years. Ann Surg. 1993 Apr. 217(4). P 375-84.

36. Nagasue N. Liver resection for hepatocellular carcinoma: indications, techniques, complications, and prognostic factors. J Hepatobiliary Pancreat Surg. 1998;5(1):7-13

37. Okamoto-E; Kyo-A; Yamanaka-N; Tanaka-N; Kuəata-K. Prediction of the safe limits of hepatectomy by combined volumetric and functional measurements in patients əith impaired hepatic function. Surgery. 1984 May; 95(5): 586-92

38. Panis-Y; McMullan-DM; Emond-JC. Progressive necrosis after hepatectomy and the pathophysiology of liver failure after massive resection. Surgery. 1997 Feb; 121(2): 142-9

39. Pinkerton JA, Saəyers JL, Foster JH. A study of the postoperative course after hepatic lobectomy. Ann-Surg 1971: 173 (5): 800-811

40. Pitre-J; Houssin-D; Kracht-M. Resection of hepatocellular carcinomas. Analysis of prognostic factors of a multicenter series of 153 patients Gastroenterol-ClinBiol. 1993; 17(3): 200-6

41. Planas R. Therapeutic Paracentesis. In: ArroyoV, Bosch J, Rodes J. Treatments in Hepatology. Masson, SA, Barcelone 1995, 59-62

42. Roger-V; Balladur-P; Honiger-J; Delelo-R; Baudrimont-M; Robert-A; CalmusY; Capeau-J; Nordlinger-B. A good model of acute hepatic failure: $95 \%$ hepatectomy. Treatment by transplantation of hepatocytes. Chirurgie. 1996; 121(6): 470-3

43. Rose DM, et al. Management of bronchobiliary fistula as a late complication of hepatic resection. Am Surg. 1998 Sep;64(9):873-6. 
44. Schinella M; Guglielmi A; Veraldi GF et all. Evaluation of the liver function of cirrhotic patients based on the formation of monoethylglycine xylidide (MEGX) from lidocaine. Eur J Clin Chem Clin Biochem. 1993 Sep. 31(9). P 553-7.

45. Segaəa T, Tsuchiya R, Furui J et al. Operative results in 143 patients əith hepatocellular carcinoma. Đorld J Surg 1993;17(5): 663-667

46. Shimada-M; Takenaka-K; Kaəahara-N; Kajiyama-K; Yamamoto-K; Shirabe-K; Nishizaki-T; Yanaga-K; Sugimachi-K. Surgical treatment strategy for patients əith stage IV hepatocellular carcinoma. Surgery. 1996 May; 119(5): 517-22

47. Shimamura T, Nakajima Y, Une Y, Namieno T, Ogasaəara K et all. Efficacy and safety of preoperative percutaneous transhepatic portal embolisation əith absolute ethanol: A clinical study. Surgery. 1997 Feb; 121(2): 135-41

48. Shimada-M; Matsumata-T; Akazaəa-K; Kamakura-T; Itasaka-H; Sugimachi-K; Nose-Y. Estimation of risk of major complications after hepatic resection. Am-JSurg. 1994 Apr; 167(4): 399-403

49. Shahrudin-MD; Noori-SM. Biloma and biliary fistula associated əith hepatorrhaphy for liver injury. Hepatogastroenterology. 1997 Mar-Apr; 44(14): 519-21

50. Stone MD, Benotti PN. Liver resection. Preoperative and postoperative care. In: Liver resection.Surg-Clin-North-Am, 1989: 69(2): 383-392

51. Stiegmann GV. Endoscopic liation of esopageal varices. In: ArroyoV, Bosch J, Rodes J. Treatments in Hepatology. Masson, SA, Barcelone 1995, 53-58.

52. Sun-J; Toshinori-I; Zhang-P. Enhancement of tumor groəth after partial hepatectomy and blood transfusion. Chung-Hua-Chung-Liu-Tsa-Chih. 1996 Mar; 18(2): 113-5

53. Taylor-M; Forster-J; Langer-B; Taylor-BR; Greig-PD; Mahut-C. A study of prognostic factors for hepatic resection for colorectal metastases. Am-J-Surg. 1997 Jun; 173(6): 467-71

54. Textbook of Surgery. D C Sabiston. 14-th ed. 1991 p:1017.

55. Tiao GM, Fisher JE. Preoperative management and nutrition in patients oith liver an biliary tract desease. Shacklefors's Surgery of the Alimentary Tract, $1996 \mathrm{ed}$. Volume III: 578-599

56. Uetsuji S; Komada Y; Kəon AH; Imamura A; Takai S; Kamiyama Y. Prevention of pleural effusion after hepatectomy using fibrin sealant. Int Surg. 1994 Apr-Jun. 79(2). P 135-7. 
57. Oilliams R. Treatment of acute liver failure. In: ArroyoV, Bosch J, Rodes J. Treatments in Hepatology. Masson, SA, Barcelone 1995, 365-374

58. Әu-CC; Ho-ӘL; Yeh-DC; Huang-CR; Liu-TJ; P'eng-FK. Hepatic resection of hepatocellular carcinoma in cirrhotic livers: is it unjustified in impaired liver function? Surgery. $1996 \mathrm{Jul} ; 120(1)$ : 34-9

59. Ou CC, et al. Prospective randomized trial of systemic antibiotics in patients undergoing liver resection. Br J Surg. 1998 Apr;85(4):489-93.

60. Yamanaka-N; Okamoto-E; Oriyama-T; Fujimoto-J; Furukaəa-K; Kaəamura-E; Tanaka-T; Tomoda-F. A prediction scoring system to select the surgical treatment of liver cancer. Further refinement based on 10 years of use. AnnSurg. 1994 Apr; 219(4): 342-6

61. Yamanaka N; Okamoto E; Kaəamura E et all. Dynamics of normal and injured human liver regeneration after hepatectomy as assessed on the basis of computed tomography and liver function. Hepatology. 1993 Jul. 18(1). P 79-85.

62. Yanaga-K; Takenaka-K; Yamamoto-K; Nishizaki-T; Shirabe-K; Shimada-M; Kaəahara-N; Chishaki-A; Sugimachi-K. Cardiac complications after hepatic resection. Br-J-Surg. 1996 Oct; 83(10): 1448-51

63. Yamamoto-J; Kosuge-T; Takayama-T; Shimada-K; Yamasaki-S; Ozaki-H; Yamaguchi-N; Mizuno-S; Makuuchi-M. Perioperative blood transfusion promotes recurrence of hepatocellular carcinoma after hepatectomy. Surgery. 1994 Mar; 115(3): 303-9

64. Yanaga K; Matsumata T; Hayashi H; Shimada M; Urata K; Suehiro T; Sugimachi K . Effect of diabetes mellitus on hepatic resection. :Arch Surg. 1993 Apr. 128(4). P 445-8.

65. Zoedler-T; Ebener-C; Becker-H; Roeher-HD. Evaluation of liver function tests to predict operative risk in liver surgery. HPB-Surg. 1995; 9(1): 13-8 